\title{
PROPRIEDADES DE SOLOS SOB FLORESTA NATURAL E SUA ALTERACÃO EM CONSEQUÊNCIA DO DESMATAMENTO E CULTIVO, NA AMAZÔNIA ORIENTAL
}

\author{
PAULO FERNANDO DA SILVA MARTINS
}

Orientador: Prof. Dr. CARLOS CLEMENTE CERRI

Tese apresentada à Escola Superior de Agricultura "Luiz de 'Queiroz", da Universidade de São Paulo, para obtenção do título de Doutor em Agronomia. Área de concentração: Solos $\theta$ Nutrição de Plantas.

PIRACICABA

Estado de São Paulo - Brasil

Março - 1987 
Aos meus pais e irmãos

A minha espôsa

Aos meus fithos

Ao caboclo da Amazônia

D E D I C 0 


\section{AGRADECIMENTOS}

0 autor expressa seus agradecimentos às seguintes pes soas e instituições.

Ao Profọ Dr. CARLOS CLEMENTE CERRI pela efetiva orientação' prestada.

Aos pesquisadores da ORSTOM, ARMAND CHAUVEL, BORIS VOLKOFF e FRANCIS ANDREUX, pela ajuda e sugestões concedidas.

Aos amigos e colegas que sempre nos incentivaram.

FACULDADE DE CIENCIAS AGRARIÁS DO PARÁ pela oportunidade concedida para a realização do doutorado.

ESCOLA SUPERIOR DE AGRICULTURA " LUIZ DE QUEIROZ " pelo treinamento recebido.

COORDENAÇÃO DE APERFEIÇOAMENTO DE PESSOAL DE NIVEL SUPERIOR - CAPES - pela bolsa de estudos concedida.

EMPRESA BRASILEIRA DE PESQUISA AGROPECUÁRIA - EMBRAPA pela ajuda financeira na execuçao deste trabalho.

A todos aqueles que de algum modo contribuiram para a reali zaçao deste trabalho. 


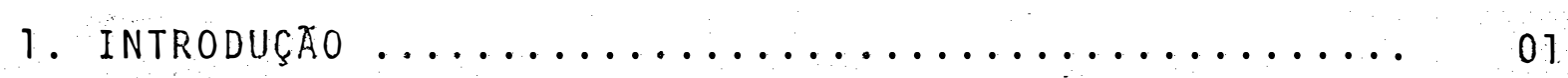

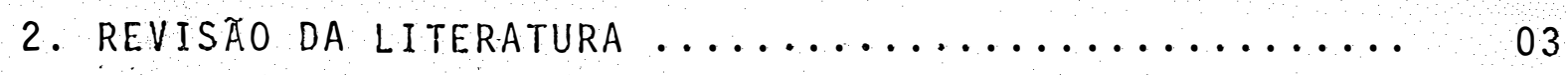

2.1. Ecossistema Natural de Floresta de Terra Firme. 03 2.1.1. Fitromassa Aérea ............... 04

2.1.2. Liteira .................. 05

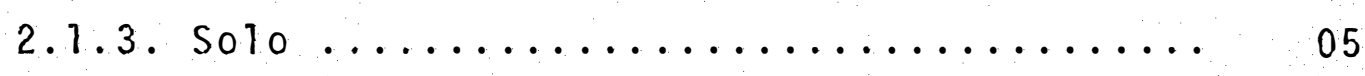

2.2. Alteração do Ecossistema Natural de Floresta de Terra Firme ....................... 07

2.2.1. Tipos de Exploração ............ 07

2.2.2. Desmatamento .................. 11

2.3. Consequēncias da Alteração sobre a Matéria Orgã

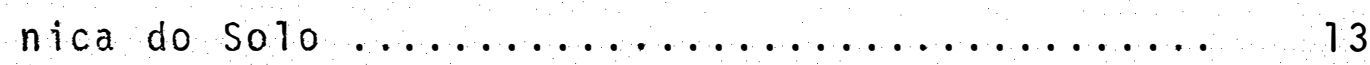

2.3.1. Modificaçöes da Fitomassa ......... 14

2.3.2. Modificações no solo .............. 19

2.4. Implicaçöes Ecológicas e Agronōmicas ........ 25

2.4.1. Transferência de Carbono para a Atmosfera 26

2.4.2. Conservação do solo ............... 27

2.4.3. Fertilidade do solo ............. 30

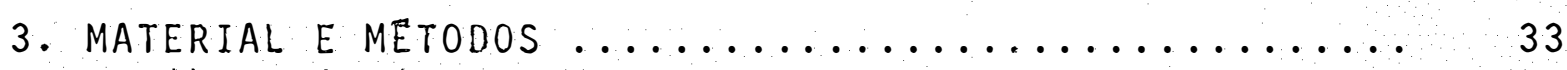

3.1. Caracterização do Meio F.îsico........... 33

3.1 .1 . Localização ................. 33

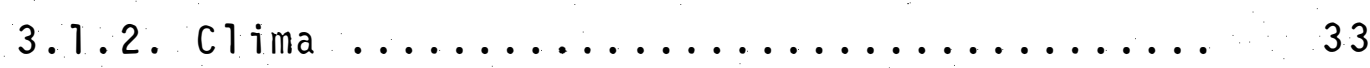

3.1.3. Vegetação ................ 35 
Pāgina

3.1.4. Geomorfologiâ e Relevo ............. 37

3.1.5. Geologia .......................... 37

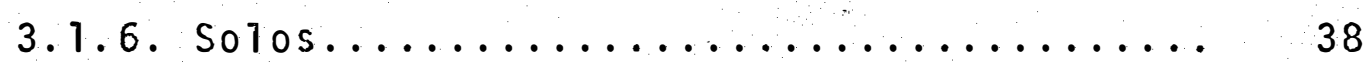

3.2. Descrição das condições do Ecossistema ........ 38

3.2.1. Ecossistema Natural ............ 38

3.2.1.1. Pedon Imperfeitamente Drenado ... 40

3.2.1.2. Pedon Moderadamente Drenado... 42

3.2.1.3. Pedon Bem Drenado......... 44

3.2.2. Ecossistema Alterado ........... 45

3.2.2.1. Area Recēm-Queimada....... 47

3.2.2.2. Area Cultivada por 1 Ano..... 48

3.2.2.3. Area Cultivada por 5 Anos.... 50

3:2.2.4. Area em Pousio de 3 Anos após

2 Anos de Cultivo.......... 52

3.3. Amostragem 54

3.3.1. Residuos Vegetais sobre o Solo....... 54

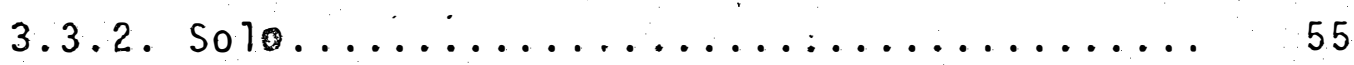

3.4. Preparo das Amostras ............... 57

3.4.1. Amostras da Liteira e Resîduos Vegetais. 57

3.4.2. Amostras de solo .............. 57

3.5. Anāitises...................... 58

3.5.1. Matēria Orgãnica do Solo........... 58

3.5.1.1. Carbono e Nitrogēnio Totais... 59

3.5.3. 2. Fracionamento Granulomētrico.. 59

3.5.1.3. Fracionamento do Húmus....... 59

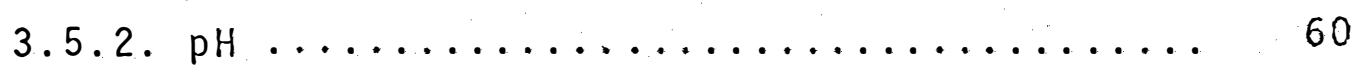


Pāgina

3.5.3. Complexo de Troca Iônica........... 60

3.5.4. Granutometria ................ 60

3.5.5. Relações Massa/Volume ........... 61

3.5.5.1. Densidade de Particulas...... 61

3.5.5.2. Densidade do Solo......... 61

3.5.6. Micromorfologia $\ldots \ldots \ldots \ldots \ldots \ldots 62$

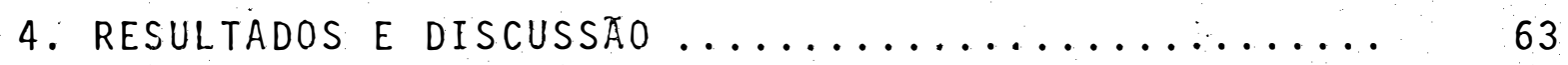

4.1. Ecossistema Natura1..................... 63

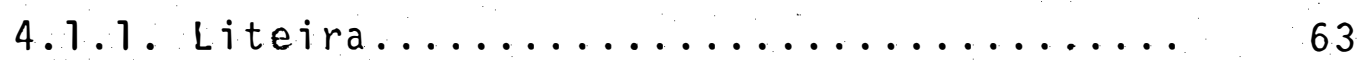

4.1 .1 .1$. Peso................ 64

4.1.1.2. Decomposição ........... 71

4.1.1.3. Quantidades de Carbono e Nitro

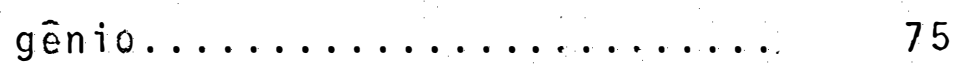

4.1.2. Horizontes Minerais........... 77

4.1.2.1. Carbono e Nitrogēnio....... 79

4.1.2.2. pH e Complexo de Troca Iōnica. 85

4.1.2.3. Textura................. 89

4.1.2.4. Densidade e Porosidade...... 89

4.1.2.5. Micromorfologia......... 92

4.2: Ecossistema Alterado............... 102

4.2.1. Residuos Vegetais sobre o Solo....... 102

4.2.1.1. Recëm-queimado .......... 102

4.2.1.2. Cultivado por 1 Ano ......... 105

4.2.1.3. Cultivado por 5 Anos........ 107

4.2.1.4. Pousio de 3 Anos após 2 Anos de Cultivo................ 108 
Pàgina

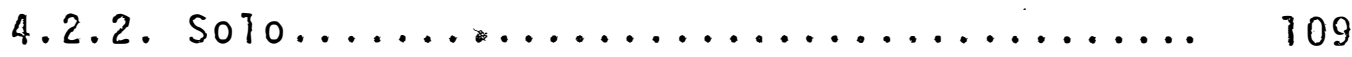

4.2.2.1. Recēm-Queimado.......... 114

4.2.2.1.1. Carbono e Nitrogênio 115

4.2.2.1.2. $\mathrm{pH} \ldots \ldots \ldots \ldots \ldots \ldots, 116$

4.2.2.1.3. Complexo de Troca

Iōnica.......... 116

4.2.2.1.4. Densidade e Porosidade ........... 119

4.2.2.2. Cultivado por 1 Ano .......... 121

4.2.2.2.1. Carbono e Nitrogê-

nio........... 122

4.2.2.2.2. $\mathrm{pH} \ldots \ldots \ldots \ldots \ldots \ldots, 123$

4.2.2.2.3. Complexo de Troca Iōnica............ 124

4.2.2.2:4. Densidade e Porosidade.............. 125

4.2.2.3. Cultivado por 5 Anos......... 125

4.2.2.3.1. Carbono e Nitrogēnio 125

4.2.2.3.2. $\mathrm{pH} \ldots \ldots \ldots \ldots \ldots \ldots 126$

4.2.2.3.3. Complexo de Troca

Iónica .......... 127

4.2.2.3.4. Densidade e Porosida de............ 128

4.2.2.4. Pousio de 3 Anos após 2 Anos de Cultivo ................ 129

4.2.2.4.1. Carbono e Nitrogēnio 129 
Pāgina

4.2.2.4.2. $\mathrm{pH} \ldots \ldots \ldots \ldots \ldots \ldots \ldots$

4.2.2.4.3. Complexo de Troca Iônica.......... 130

4.2.2.4.4. Densidade e Porosida de............ 131

4.3. Consequência da Alteração do Ecosistema ...... 132 4.3.1. Mudanças na Vegetação ............. 132 4.3.2. Mudanças nos Resíduos Vegetais sobre o soro ........................ 134 4.3.2.1. Efeitos da Queimada......... 134 4.3.2.1.1. Peso dos Residuos... 134 4.3.2.1.2. Distribuição dos Com ponentes.......... 135

4.3.2.1. 3. Perdas por Volatilização............ 136

4.3.2.2. Efeitos do Cultivo e do Pousio. 137 4.3.2.2.1. Peso dos Residuos... 137 4.3.2.2.2. Distribuição dos Com ponentes ......... 138

4.3.2.2.3. Quantidade de Carbono e Nitrogènio....

4.3.3. Mudanças no Solo................. 141

4.3.3.1. Carbono :e Nitrogēajo......... 141

4.3.3.1.1. Efeitos da Queimada. 142 4.3.3.1.2. Efeitos do Cultivo do Pousio........ 145

4.3.3.2. Complexo de Troca Iônica .... 148 4.3.3.2.1. Efeitos da Queimada 148 
4.3.3.2.2. Efeitos do Cultivo e do Pousio........ 150

4.3.3.3. Densidade e Porosidade....... 155

4.3.3.3.1. Efeitos da Queimada.. 156 4.3.3.3.2. Efeitos do Cultivo e do Pousio........ 157

4.3.3.4. Micromorfologia........... 160

4.3.3..4.1. Area Cultivada por 1 Ano $\ldots \ldots \ldots 160$

4.3.3.4.2. Area Cultivada por 5 Anos.......... 162

4.3.3.4.3.. Ârea de Pousio de 3 Anos apōs 2 Anos de

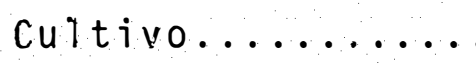

$4.3 .3 .4 .4 \ldots$ Mudanças na Sequên cia Floresta-cultivo-Pousio.......... 166

4.4. Dinâmica da Matēria Organi ca da Parte Superior do Solo ... 168 4.4.1. Fracionamento Granulomētrico ........... 169 4.4.1.1. Ecossistema Natura1........ 169 4.4.1.2. Ecossistema Alterado..........173 4.4.2.. Fracionamento do Húmus............ 175 4.4.2.1. Ecossistema Natura1.......... 175 4.4.2.2. Ecossistema A1terado......... 178 
Página

4.4.3. Evolução da Matēria Orgãnica $\ldots \ldots \ldots \ldots . . .180$

5. CONCLUSJes............................ 186

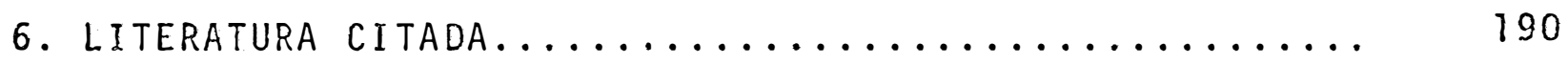

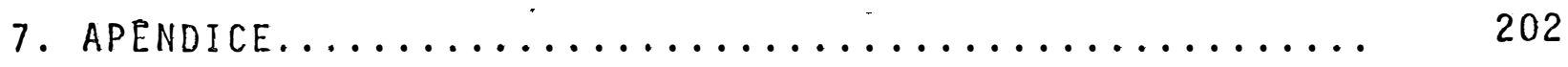




\section{INDICE DE TABELAS}

Iabela.

Pàgina

1 Peso do material úmido, peso do material seco, quantida de de carbono, nitrogēnio e relação $C / N$ dos diver sos componentes da liteira no ecossistema natural....

2 Indices de desagregação da liteira e de seus componentes considerando duas fases de decomposição.

3 Teores de carbono e nitrogēnio totais, relação $\mathrm{C} / \mathrm{N}$, valores de $\mathrm{pH}$ - em àgua e KCl - e $\Delta \mathrm{pH}$ dos horizontes minerais do ecossistema natural ........

4 Distribuição do carbono atē $200 \mathrm{~cm}$ de profundida-

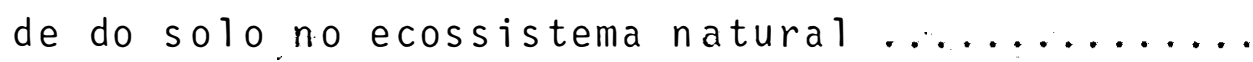

5 Cátions trocáveis, soma de bases (S), capacidade de troca de cátions (T) e valor de saturação em ba ses $(V \%)$ dos horizontes minerais do ecossistema na

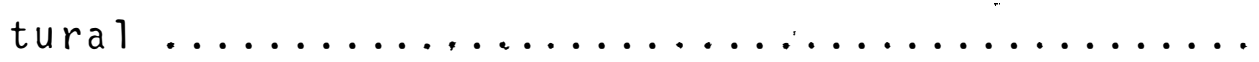

6 Classes de textura e valores de densidade e porosidade do solo no ecossistema natural ..........

7 Peso do material úmido, peso do material seco, quan tidade de carbono, nitrogênio e relação $C / N$ dos residuos vegetais depositados na superfície do so

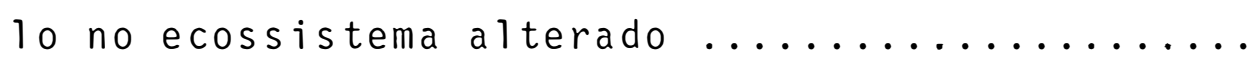

8 Distribuição percentual das frações granulométri cas nas classes de 0-50 (subdividida em 0-2 e 250), 50-200, 200-2000 $\mu \mathrm{m}$ e grau de floculação do horizonte $A$ do solo sob diferentes condições do ecossistema 
Tabela

9 Teores de carbono e nitrogēnio totais, relação $\mathrm{C} / \mathrm{N}$, valores de $\mathrm{pH}$ - em àgua e $K C l$ - e $\Delta \mathrm{pH}$ do solo no ecossistema alterado $\ldots \ldots \ldots \ldots \ldots \ldots \ldots \ldots$

10 Conteúdo de carbonoe nitrogēnio ate $100 \mathrm{~cm}$ de profundidade do solo no ecossistema natural e no

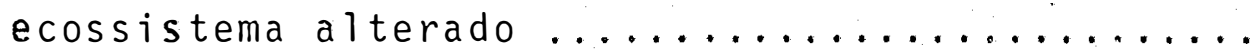

11 Cátions trocáveis, soma de bases (S), capacidade de troca de cátions (T) e valor de saturação em bases $(V \%)$ do solo no ecossistema alterado ......

12 Classes de textura e valores de densidade e porosidade do solo no ecossistema alterado .........

13 Quantidade de carbono distribuida por classe de diàmetro dos galhos existentes no ecossistema na-

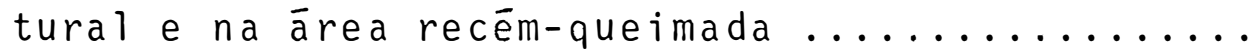

14 Distribuição do carbono atē $100 \mathrm{~cm}$ de profundidade do solo no ecossistema natural e no ecossiste-

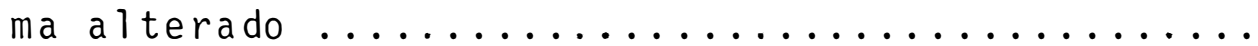

15 Distribuição do carbono nas frações F 200 - 2000 $(200$ a $2000 \mu \mathrm{m}), F 50-200(50-200 \mu \mathrm{m})$ e F $0-50$ $(0-50 \mu \mathrm{m})$ do horizonte $A$ do solo sob diferen -

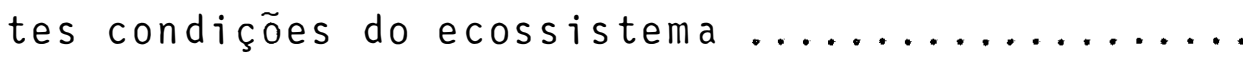

16 Distribuição dos compartimentos hūmicos da fração F 0-50 (0 a $50 \mu \mathrm{m})$ do horizonte A do solo: AFL-ācido fülvico livre, H - humina, AHS - ácido húmico ex traído pela soda, AFS-ácido fūlvico extraído pela 
Tabela

soda, AHP - ácido húmico extraído pelo pirofosfato de sódio, AFP - ācido fūlvico extraîdo pelo piro fosfato de sódio, AH - ácido húmico total, AF -āci

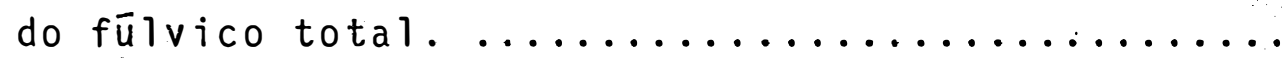

17 Distribuição do carbono contido na parte superior dó solo (liteira - ou residuos vegetais sobre a su perficie - mais horizonte A) sob diferentes condi-

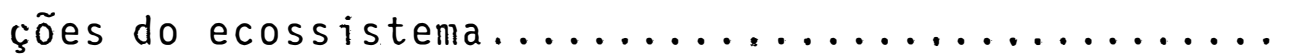




\section{INDICE DE FIGURAS}

Figura

Pāgina

1 Indicação do local do estudo $\ldots \ldots \ldots \ldots \ldots \ldots$

2 Balanço hîdrico do município de Capitão Poço-Parā. 36

3 Esquema da parte superior do solo sob ecossistema natural: imperfeitamente drenado, moderadamen-

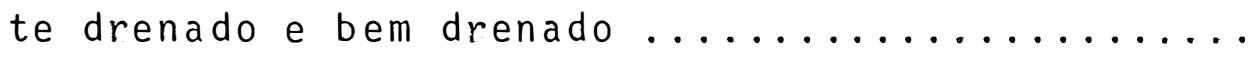

- 4 Esquema da parte superior do solo sob ecossistema alterado: recém-queimado, cultivado por 1 ano, cultivado por 5 anos e pousio de 3 anos (após 2

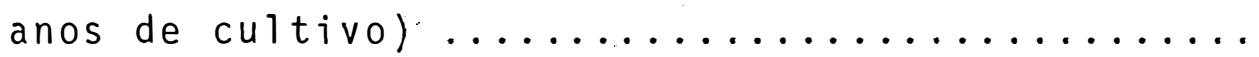

5 Distribuição relativa dos componentes da liteira

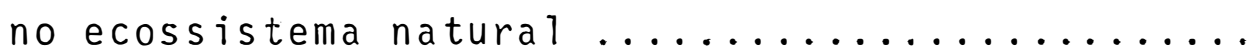

6 Distribuição relativa dos fragmentos da liteira n ecossistema natural $\ldots \ldots \ldots \ldots \ldots \ldots \ldots$

7 Fotomicrografia $(12 X)$ relativa ao horizonte $A_{12}$ $(6-10 \mathrm{~cm})$ do Pedon Imperfeitamente Drenado do Ecos sistema Natural: Distribuição enaulic com um esqueleto constituído principalmente de quartzo, um plasma bruno escuro com distribuição irregular bas tante microagregado e a presença de raízes e res I

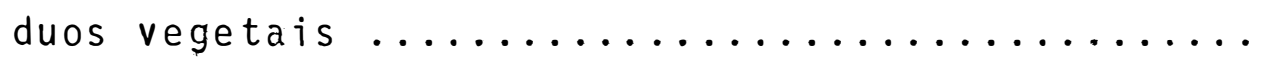

8 Fotomicrografia ( $12 \mathrm{X})$ relativa ao horizonte $\mathrm{A}_{3}$ $(10-18 \mathrm{~cm})$ do Pedon Imperfeitamente Drenado do Ecos sistema Natural: Plasma regularmente distribuî́do, envolvendo grande parte do esqueleto, exibindo uma macroporosidade relativamente pouco desenvolvida. A direita ap̣arece um nódulo férrico ..... 
Figura

$\underline{\text { Pàgina }}$

9 Fotomicrografia (53X) relativa ao horizonte $B_{21}$ $(32-50 \mathrm{~cm})$ do Pedon Imperfeitamente Drenado do Ecos sistema Natural: Distribuição porfiric onde o pias ma se apresenta contínuo, a macroporosidade muito reduzida e os grãos de quartzo agrupados os quais contém grande quantidade de ōxido de ferro encrus tado. Vazios do tipo fissural são limitados por

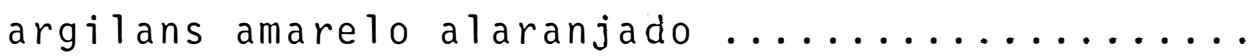

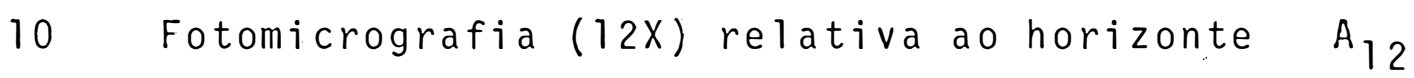
(4-8cm) do Pedon Moderadamente Drenado do Ecossistema Natural: Distribuição heterongēnea do p̣las ma de cor bruno muito escuro, muito microagregado e com um padrão enaulic. Numerosas raízes e elevada porosidade intersticial entre os grãos do

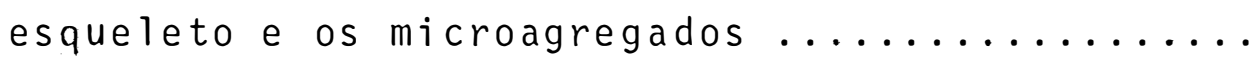

11 Fotomicrografia (53X) relativa ao horizonte ${ }_{11}$ $(15-30 \mathrm{~cm})$ do Pedon Moderadamente Drenado do Ecossistema Natural: Presença de pequenos agregados milimétricos de forma relativamente arredondada delimitados por vazios policóncavos de aproximadamente $1 \mathrm{~mm}$ de diàmetro. Note-se tambēm a distribuição agrupada do esqueleto e a forte incrustação de óxido de Fe nos grãos de quartzo ...

12 Fotomicrografia (33X) relativa ao horizonte ${ }^{B_{2} 2}$ $(60-70 \mathrm{~cm})$ do Ecossistema Natural: Em um padrão de distribuição porfiric distingue-se, à direita, se 
tores de plasma muito claro com macroporosidade muito reduzida devido o preenchimento dos vazios por cutans argilosos, associados a pequenas manchas avermelhadas e violáceas com limites difusos; à esquerda a ocorrência de vazios policōncavos, também com manchas avermelhadas com limites difusos,

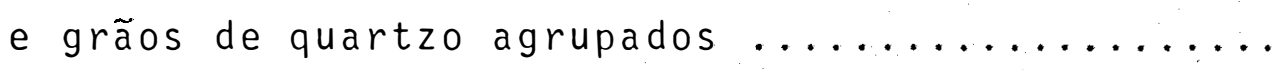

13 Fotomicrografia (24X) relativa ao horizonte $B_{23}$ $(110-170 \mathrm{~cm})$ do Pedon Moderadamente Drenado do Ecos Sistema Natura 1: Aspectos da degradação de um mate rial endurecido muito rico em plasma de coloração bruno, muito associado aos vazios ..........

14 Fotomicrografia $(13 X)$ relativa ao horizonte $B_{32}$ $(210-230 \mathrm{~cm})$ do Pedon Moderadamente Drenado do Ecos sistema Natural: Degradação de nōdulos férricosque parecem fundir-se à matriz constituída principalmen te de um plasma bruno amarelo que envolve os grãos de quartzo em um padrão tipicamente porfiric ....

15 Fotomicrografia $(33 \mathrm{X})$ relativa ao horizonte $\mathrm{A}_{3}$ $(10-20 \mathrm{~cm})$ do Pedon Bem Drenado do Ecossistema Natu ral: Sobre um fundo matricial de padrão de distribuição enaulic tendendo a monic e contendo um plasma de coloração bruno escuro destaca-se, à direita, um pedotubo com orientação vertical contendo peque nos grãos de quartzo (areia fina e silte grosso). 
16 Fotomicrografia ( $53 \mathrm{X}$ ) relativa.ao horizonte $\mathrm{B}_{12}$ $(50-75 \mathrm{~cm})$ do Pedon Bem Drenado do Ecossistema Natural: Padrão de distribuição porfiric onde o plas ma é pouco agregado; os grãos de quartzo apresentam-se relativamente agrupados, e a macroporosida de é muito reduzida. Note-se depósitos argilosos com limites difusos em torno dos vazios e, à esquerda, a presença de um grão verde de horn-

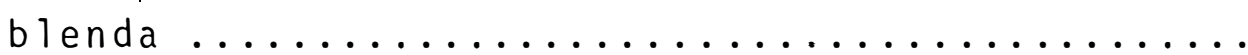

17 Distribuição percentual das frações granulométrị cas nas classes de 0-50 (subdividida em 0-2 e 0$50), \quad 50-200,200-2000 \mu m$ e grau de floculação: do horizonte A no ecossistema natural e no ecossiste

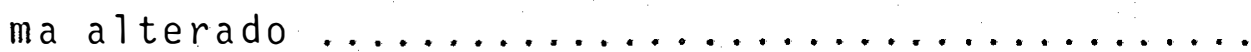

18 Distribuição percentual do carbono do solo no ecos sistema natural e no ecossistema alterado ......

19 Distribuição dos valores de pH (em água) do solo no ecossistema natural e no ecossistema alterado.

20 Distribuição dos valores de capacidade de troca de cätions no ecossistema natural e no ecossistema al terado $\ldots \ldots \ldots \ldots \ldots \ldots \ldots \ldots \ldots \ldots \ldots \ldots \ldots \ldots \ldots \ldots \ldots \ldots$

21 Distribuição dos valores de saturação em bases no ecossistema natural e no ecossistema alterado ....

22 Distribuição dos valores de densidade do solo no ecossistema natural e no écossistema alterado... 
23 Fotomicrografia (12X) relativa.ao horizonte $A_{12}$ $(6-15 \mathrm{~cm})$ do solo na ārea Ciultivada por 1 ano: Aspecto do plasma bruno distribuido em uma massa continua em consequéncia dos efeitos do desmatamento apōs 1 ano de cultivo, acentuando 0 padrão de distribuição agrupada do esqueleto. Note-se a variação acentuada na cor do plasma prō-

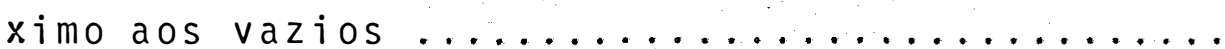

24 Fotomicrografia (24X) relativa ao horizonte. $\mathrm{A}_{3}$ $(15-25 \mathrm{~cm})$ do solo na ārea Cultivada por 1 ano: Presença de pequenos cutans argilosos de cor bruno amarelo claro no centro da foto. Note-se também ao centro e à esquerda setores onde o

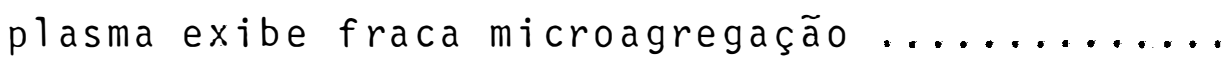

25 Fotomicrografia $(33 \mathrm{X})$ relativa ao horizonte $\mathrm{B}_{12}$ $(35-75 \mathrm{~cm})$ do solo na ārea Cultivada por 1 ano: Distingue-se o contato de dois fundos matriciais diferentes: à esquerda onde o plasma é bruno acinzentado, o esqueleto é abundante e existem microagregados e residuos vegetais; à direita on de o plasma é bruno mais claro, mais abundante, formando uma massa continua, e a macroporosidade

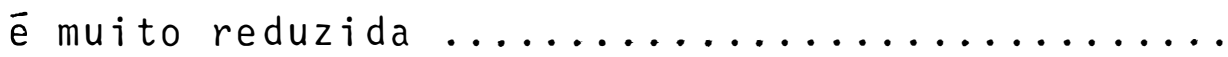

26 Fotomicrografia $(12 x)$ relativa ao horizonte $A_{1}$ $(0-7 \mathrm{~cm})$ do solo na ärea Cultivada por 5 anos: ocorrência de um plasma pouco abundante que ten- 
de a se concentrar em torno dos vazios de origem biológica. No centro da fotografia observa-se um fragmento de carvão vegetal proveniente da queimada da vegetação $\ldots \ldots \ldots \ldots \ldots \ldots \ldots \ldots \ldots \ldots \ldots \ldots$

27 Fotomicrografia $(33 x)$ relativa ao horizonte $A_{3}$ $(7-17 \mathrm{~cm})$ do solo na área Cultivada por 5 anos: Plasma bruno irregularmente distribuído, separa do por meta vazios revestidos por cutans de argi la ladeados por uma bordadura de cor. vermelha. No centro da fotografia aparece um grão de stau-

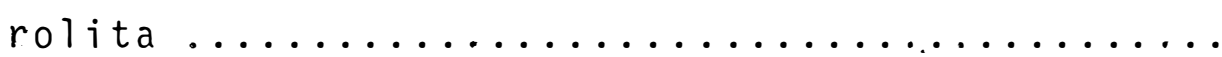

28 Fotomicrografia $(12 x)$ relativa ao horizonte ${ }^{B_{12}}$ $(32-45 \mathrm{~cm})$ do solo na área Cultivada por 5 anos: Aspecto da heterogeneidade do fundo matricial e da descontinuidade textural decorrente da altera ção da estrutura do solo. Note-se a alternāncia de setores arenosos de contornos festonados com setores onde os grãos de quartzo estão envol

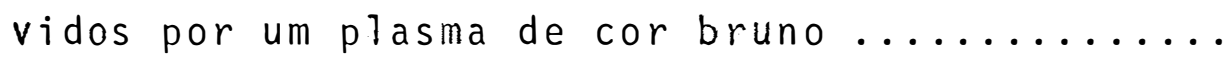

29 Fotomicrografia (12X) relativa ao horizonte $A_{12}$ $(2-7 \mathrm{~cm})$ do solo na ārea em Pousio: Em um fundo matricial enaulic, muito semelhanté ao da ārea cultivada por 5 anos, destacam-se peletes fecais de diâmetro de aproximadamente $1 \mathrm{~mm}$ que se anastomosam formando agregados compostos ......... 
30 Fotomicrografia (53X) relativa ao horizonte $B_{12}$ $(30-40 \mathrm{~cm})$ do solo na área em Pousio: Nos limites de um canal, que se dispõe transversalmente na foto, observa-se grande quantidade de peletes fe cais oriundos de intensa pedoturbação ........

31 Distribuição relativa. do carbono nas frações 0 $50 \mu \mathrm{m}, 50-200 \mu \mathrm{m}$ e 200-2000 $\mu \mathrm{m}$ do horizonte A do solo. Ecossistema natural: $N_{1}$ - imperfeitamente drenado, $\mathrm{N}_{2}$ - moderadamente drenado, $\mathrm{N}_{3}$ - bem drenado. Ecossistema alterado: Q - recém-queima do, A - cultivado 1 ano; I - cultivado 5 anos, $P$ - pousio de 3 anos (após 2 anos de cultivo)..

32 Distribuição relativa dos compartimentos hümicos da fração 0-50 $\mu \mathrm{m}$ do horizonte $A$ do solo sob di-

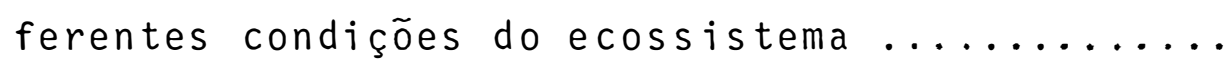

33 Distribuição do carbono contido na parte superior do solo (liteira - ou residuos vegetais sobre a superficie - mais horizonte A) sob diferen

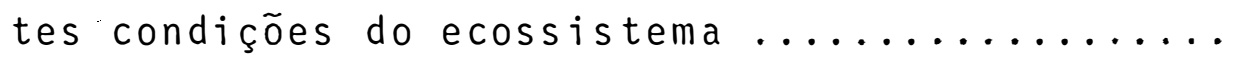


PROPRIEDADES DE SOLOS SOB FLORESTA NATURAL E SUA ALTERAÇAO EM CONSEQUENCIA DO DESMATAMENTO E CULTIṾO, NA AMAZONIA ORIENTAL

Candidato: PAULO FERNANDO DA SILVA MARTINS

Orientador: Prof. Dr. CARLOS CLEMENTE CERRI

RESUMO

Foram avaliadas as propriedades fisicas e quimicas dos solos de um ecossistema natural de terra firme e sua alteração em decorrência do desmatamento e do cultivo.

0 estudo foi realizado na Amazónia Oriental, Es tado do Pará (Brasil), municīpio de Capitão Poço, na Estação Experimental do Centro de Pesquisa Agropecuária do Trópico Omido, e adjacēncias, em Latossolo Amarelo e Podzólico Vermelho Amarelo.

Tomando-se por base os solos sob condições naturais, verificou-se as modificações ocorridas na sequência queimada-cultivo-pousio. Foram estudados os seguintes aspectos: evolução da matéria orgānica, alteração do complexo de troca ionica e alteração da estrutura, incluindo análise micromorfológica.

Constatou-se que no ecossistema estudado os so los possuem originalmente uma organização pedológica caracte- 
rizada por um adensamento natural que é agravado onde a textu ra é mais fina. Embora localizado em cotas elevadas e apresentando relevo plano, possuem drenagem variável e muitas vezes deficiente. Com o desmatamento e o cultivo, a auséncia de vegetação que propicie adições constantes de resîduos acar retam mudanças na quantidade e na qualidade da matéria orgâni ca., as quais afetam a organização estrutural do solo.

As modificações do solo se traduzem principa mente através do aumento do teor de àcidos fūlvicos acompanhä do da diminuição do teor de àcidos hūmicos,provocando a deses tabilização do complexo organo mineral no horizonte $A$ do so10. Em consequēncia, hā maior dispersão das friações finas que migram e obstruem os macroporos, o plasma torna-se denso, a densidade do solo aumenta e a porosidade diminui.

Apōs o segundo ano quando o cultivo é interrom. pido devido a baixa produtividade, o desenvolvimento da vegetação natural favorece o acūmulo de resỉduos que aliados a forte atividade da fauna causam a inversão do processo de a 1 teração,com a recuperação parcial da quantidade de àcidos hūmicos e diminuição do teor de àcidos fūlvicos. Ocorre a reorganização da estrutura: a microagregação reaparece, a densida de do solo diminui.

Conclui-se finalmente que o desmatamento provo ca a degradação física do solo após o primeiro ano de cultivo, e que o pousio, ao contrārio, promove a sua recuperação. 
SOIL PROPERTIES UNDER NATURAL FOREST AND ITS ALTERATION AFTER CLEARING AND TILLAGE IN THE ORIENTAL AMAZON

Author: PAULO FERNANDO DA SILVA MARTINS

Adviser: Prof. Dr. CARLOS CLEMENTE CERRI

SUMMARY

Physical and chemical soil properties under "terra firme" natural forest were appraised besides changes occured when the forest was cleared and soil cultivated.

The study was performed in the Oriental Amazon region, Pará State (Brazil), Capitão Poço Country, in the experimental center of the Centro de Pesquisas. Agropecuárias do Trópico Umido (EMBRAPA) and surrounding areas of Yellow Latosol and Red Vellow Podzolic.

Taking the soil of the forest as a base, the changes occured in the sequential managment, burning, tillage and fallow-land, were observed. The following aspects were studied in the soil: organic matter evolution, alteration in the ionic exchange as well as in the structure, including the micromorphological analyses.

It was observed that in this kind of ecosystem the soils have an original pedological organization characterized by natural compactacion, which increases as texture becomes 
finer. Although located on higher quote with flat sat-off the soil has variable drainage and deficient drainage in some cases.

With forest clearing and tillage, the absence of vegetation which is responsable for a constant adition of residuals were responsible for the changes in the quality and quantity of organic matter, which affects soil structure.

Soil modification was expressed mainly through fulvic acid increase, which is followed by a decrease of the humic acid content, giving rise to a desestabilization of the organo mineral complex in the A horizon. As a result, there is greater dispersion and migration of fine fraction which causes the obstruction of macropores, increasing soil plasma and bulk density, and lowering soil porosity.

After a second year, when the tillage was interrupted due to a lowering of productivity, the development of a natural vegetation gave rise to an accumulation of residues which together with strong soil fauna activity reversed the process of degradation, with parcial recovery of the ammount of humic acid and a decrease in the level of fulvic acids with soil structural reorganization, followed by microaggregation and lower bulk density.

Finally, it could be concluded, that forest clearing induces the soil physical degradation after first year of tillage and that fallow land acts in an inverse way, causing its recovery. 
SOLS SOUS FORET EN AMAZONIE ORIENTALE: PROPRIETES ET MODIFICATIONS CAUSEES PAR LA DEFORESTATION ET LA MISE EN CULTURE

\author{
Auteur: PAULO FERNANDO DA SILVA MARTINS
}

Directeur d'etudes: Prof. Dr. CARLOS CLEMENTE CERRI

RESUME

Cette ëtude est consacrēe aux propriētēs physiques et chimiques des sols d'un ècosystéme natural non inondable et $\bar{a}$ leurs modifications par suite de la déforestation et de la mise en culture. Elle a été réalisée en Amazonie Orientale, Etat de Parā, commune de Capitão Poço (Brésil), dans la Station Expérimentale du Centre de Recherche sur le Tropique Humide (CPATU)' et ses environs. Les sols ont été classes comme Latosols Jaune et Rouge et Jaune Podzoliques.

En prenant comme référence les sols en conditions naturelles les modifications survenant dans la sēquence brūlis-culture-jachère ont été étudiēes sous les aspects suivants: évolution de la matière organique, modifications du complexe d'échange et changements dans la structure, y compris. par analyse micromorphologique.

On a constaté que les sols possédent à l'órigine une organisation pédologique caractérisée par une densité 
naturellement élevée, en particulier là oū la texture est plus fine. Bien que situés en position élevée et plane, ils possédent un drainage variable et souvent déficient. Aprés déforestation et mise en culture, l'absence de végétation assurant un apport continu de résidus provoque des changements quantitatifs de matière organique, qui à leur tour affecte l'organisation structurale du sol.

Les modifications du sol se manifestent principalement par $7^{1}$ augmentation de la teneur en acides fulviques et la diminution de la teneur en acides humiques, provoquant la destabilisation du complexe organo-minéral dans l'horizon $A$ du sol. Il en résulice une augmentation de la dispersion des fractions fines qui migrent et obstruent les macropores, ainsi qu'un accroissement de la densité du plasma, et donc de celle du sol.

Aprés la seconde annēe, lorsque la culture est interrompue en raison de trop fortes baisses de rendement, une nouvelle végétation naturelle se développe et l'accumulation de résidus, alliée à une forte activité de la faune, provoque une inversion des processus. On assiste à la reconstitution partielle des quantitēs initiales d'acides humiques et fulviques, à la réorganisation de la structure en micro-agrégats et à une baisse de densité du sol.

On peut conclure de cette étude que la deforestation provoque la dégradation physique du sol dés la première annēe de culture et que la jachère, au contraire, tend à favoriser le retour aux propriétés initiales. 
1. INTRODUÇÃO

O desmatamento e o cultivo provocam, inevita velmente, modificações no solo, influindo sobre a sua produtivi dade. Na amazônia o cultivo tradicional é insustentāvel após 1 ou 2 anos porque a produtividade diminui drasticamente.

Devido ao rigor do clima, o desmatamento na amazônia deve causar maior vulnerabilidade do solo às modifica ções. Isto, contudo, ainda não foi suficientemente discutido por falta de pesquisas sobre o assunto. Além disto, há, por parte de alguns segmentos da sociedade a preocupação de que o desmata mento provoque alterações ecológicas de custos sociais e econômicos inaceitāveis.

Muitas āreas de terra firme na amazōnia orien tal, embora apresentem, a primeira vista, condições favorāveis à exploração agrícola, tais como: cota elevada, relevo plano, disponibilidade de água e fácil acesso; possuem problemas de drenagem. Este fato cria restrições a sua exploração agrícola, 
além de oferecer riscos de degradação do solo caso o seu manejo não seja adequado.

Os solos da Estação Experimental do Centro de Pesquisa Agropecuāria do Trōpico Omido - CPATU - de Capitão Poço (Estado do Pará), onde se instalam projetos de pesquisas sobre sistemas de produção, embora tenham sido classificados como Latosolo Amarelo (EMBRAPA, 1981), apresentam problemas de drena gem. Com o objetivo de avaliar as modificações que ocorrem nas propriedades físicas e químicas destes solos em consequência do desmatamento e do cultivo, estudou-se, tendo como base de compa ração as condições naturais, o solo de āreas próximas submeti das à queimada, ao cultivo e ao pousio. Considerando a variação de drenagem existente, selecionaram-se trēs pedons sob vegetação de floresta primária, correspondentes as classes imperfeita mente, moderadamente e bem drenados, a fim de servirem de padrão. 


\section{REVISÃO DA LITERATURA}

2.1. Ecossistema Natural de Floresta de Terra Firme

As florestas de terra firme ocupam $80 \%$ da ārea da Amazônia e englobam vārios tipos de formações florestais: mata alta, mato de cipó, mata seca, mata de bambu, campinara na, matas serranas e de neblina (SHUBART, 1983).

A predomināncia é de matas altas e a maioria dos dados aqui apresentados referem-se a āreas de sua ocorrência.

As matas altas em geral são densas, apresentam grande biomassa e elevado nümero de espécies.

Segundo TAKEUCHI (1960) nas āreas de maior altitude (terra firme alta, 60m acima do nível do mar) a flores ta é multiestratificada e as espécies mais comuns no estrato superior pertencem as famîlias Leguminosae, Lecythidaceae, e Sapotaceae e é muito reduzido o número de palmeiras de estipe alta. Nas āreas de menor altitude (terra firme baixa, $40 \mathrm{~m}$ ac $\underline{i}$ 
ma do nível do marl não se formam estratos e é elevado o núme ro de palmeiras com estipe alta. Entre as espécies de maior porte aparecem as Moraceae ao invés das Lecythidaceae.

As florestas da Amazōnia, em geral, e as florestas de terra firme, em particular, apresentam grande diver sidade de espécies. Rodrigues (1967), citado por KLINGE et alii (1975), encontrou na Amazōnia Central uma mēdia de 65 es pēcies por hectare pertencentes a 47 famîlias. DANTAS et alii (1980) encontrou, na Amazōnia Oriental (região periférica meridional, segundo FITTKAU et alii, 1975) em 1 ha, mais de 1000 indivĩduos distribuidos entre 52 famîlias e 188 espécies. Na Guiana Francesa, LESCURE (1981) verificou uma mēdia de 217 ār vores/ha com DAP acima de $20 \mathrm{~cm}$, distribuîdas entre 45 famîlias e 161 espécies, enquanto PUIG (1979a) verificou a exis tência de uma mêdia de 6222 àrvores/ha.

\subsubsection{Fitomassa Aérea}

A fitomassa da floresta Amazōnica varia em fun ção das condições edafoclimāticas. Expressa em peso seco, por exemplo, encontrou-se 467 ton/ha perto de Manaus (KLINGE et alii, 1975) e 589ton/ha na região de Sta. Elie, na Guiana Francesa (LESCURE et alii, 1982).

São produzidas anualmente 20 toneladas de ma téria seca tas quais 8 toneladas se deve à queda de folhas mortas, galhos,fiores e frutos (SHUBART, 1983). 


\subsubsection{Liteira}

A armazenagem de matéria seca na liteira é bastante variāvel mesmo dentro de uma mesma ārea. KLINGE et alii (1975) encontrou na Amazōnia Central 25,4 toneladas de matēria seca sendo $72 \%$ constituido de galhos (49\%) e folhas $(23 \%)$ e os $28 \%$ restantes de flores e frutos (1\%) e fragmentos de galhos e folhas (27\%).

Estimativas da produção anual de liteira (em peso seco) feitas na Amazōnia Central (KLINGE e RODRIGUES, 1968) na Amazônia Oriental (EMBRAPA, 1981) e na Guiana France sa (PUIG, 1979b) indicaram, respectivamente, os valores de $7,4,9,0$ e 8,7 toneladas. Neste ültimo exemplo, ao contrārio dos outros dois, a produção māxima de liteira não coincidiu com a estação seca.

A 1 iteira decompõe-se rapidamente devido as condições favorāveis de temperatura e umidade. KLINGE et alii (1975) considera que na Amazónia Central $80 \%$ das folhas das ärvores retorna anualmente ao solo.

$$
\text { 2.1.3. Solo }
$$

Duas são as ordens de solos onde em maior extensão estão situadas as florestas densas de terra firme: Latossolos (0xisol) e Podzólicos distróficos (Ultisol). Estas duas ordens correspondem a cerca de $75 \%$ da ārea da bacia amazōnica (SAN- 
CHEZ et alii, 1982). São solos profundos, bem drenados, aver melhados ou amarelados e com boas propriedades físicas, embo ra muito ācidos e deficientes em nutrientes (SANCHEZ e BUOL, 1975).

Estudos do solo sob floresta de terra firme tem mostrado que a camada de. $0-10 \mathrm{~cm}$ contēm em mëdia atē $5 \%$ de matēria orgānica, ou seja, atē 60 ton/ha onde a maior parte

$195 \%$ ou. mais) se encontra na forma de humus (VOLKOFF e CERRI., 1981). A maior parte do carbono constituinte do humus encontra-se na forma de àcidos fūlvicos livres (30\%) e hu mina ( $50 \%$ ) enquanto o restante se distribui entre as frações alcalino-solúveis (ācidos hümicos e fúlvicos extraíveis pela soda e pirofosfato de sōdiol. Os primeiros centîmetros a par tir da superfície do solo possuem maior quantidade de frações alcalino-solúveis e muito pouco àcido fúlvico livre. Conforme se aumenta a profundidade diminuem as quantidades da fração alcalino-solúveis enquanto aumentam as de àcido fūlvico livre. A humina permanece relativamente constante nas diferen tes profundidades do perfil (VOLKOFF e CERRI, 1981; VOLKOFF et alii, 1982; MANARINO et alii, 1982).

E devido a predominância de ācidos fūlvicos nos horizontes subsuperficiais que os mesmos se apresentam com va lores (Mulsell) elevados. Contudo, embora a cor do horizonte B não seja escura existe quantidade importante de matéria orgânica que pode ultrapassar a $2 \%$ do peso total do horizonte. Como em todo ecossistema natural terrestre, na floresta Amazônica existe estreita relação entre a vegetação 
e o solo. Contudo em termos de nutrientes a vegetação depende muito mais de si mesmo e da liteira que do solo, chegando mes mo a se nutrir, em parte, diretamente dos produtos de decompo sição da liteira (Stark, citado por VOLKOFF e CERRI, 1981). A vegetação possui, armazenados na fitomassa, 4 vezes mais bases ( $k$, Ná, Ca, Mg) do que existe a tē 1 metro de profundidade $(274 \mathrm{~kg} / \mathrm{ha})$ e pelo menos $4 \%$ dessas bases são transferidas anu almente para o solo atravēs de decomposição da liteira (SHUBART, 1983) enquanto são transferidos $5 \%$ do Ca mais Mg, por lavagem das copas e do caule (considerando precipitação anual de $2.500 \mathrm{~mm}$ e dados de SANTOS et alii, 1981). Ambos os processos são mais intensos no periodo chuvoso.

As características da vegetáção dependem das condições do solo, especialmente do seu regime hỉdrico. BOULET (1981) refere-se a variações na fitomassa em função da drenagem do solo assinalando a ocorrēncia de ārvores com DAP superior a $90 \mathrm{~cm}$ em nümero très vezes maior em uma ärea com drenagem vertical livre, em relação a outra, adjacente, com drenagem vertical bloqueada.

2.2. Alteração do Ecossistema Natural de Floresta de Terra Firme

2.2.1. Tipos de Exploração

A maior parte da alteração dos ecossistemas de terra firme Amazōnica visa a implantação de atividades agrî́co las, florestais ou pastoris. 
A atividade agrícola inclui várias formas de cultivo: cultivo itinerante, cultivo intensivo, cultivo de plantas perenes, com ou sem consōrcio.

0 cultivo itinerante é a forma tradicional e jā vem sendo utilizada hā muito tempo pois iniciou com as tri bos indigenas da região. Consiste em se derrubar e queimar $\bar{a}-$ reas de florestas primārias para cultivar a terra por poucos anos usando cultivos de subsistência e depois deixā-la em pou sio por vārios anos. O nümero de anos de cultivo é variāvel em função da fertilidade natural do solo, mas na maioria das vezes é de 2 a 4 anos. Quando a atividade deixa de ser compen sadora, a ārea é abandonada e busca-se outra ārea de floresta primāria. Se o agricultor porventura não dispõe de āreas de floresta primāria, passa a utilizar āreas de floresta secundā ria com 10 anos ou mais de pousio, a cuja vegetação denomina "capoeira".

0 cultivo itinerante se restringe a mão-de-obra familiar e por isto mesmo abrange pequenas āreas onde basicamente são produzidos mandioca, feijão, arroz e milho, ut lizados em maior parte na alimentação da prōpria famîlia.

os outros tipos de utilização agrîcola são restritos à pequeno nūmero de proprietārios.

0 cultivo intensivo refere-se a produção de culturas de ciclo curto de maneira contínua e permanente, ao contrārio do cultivo itinerante. Basicamente existem duas modalidades de cultivo intensivo: monocultivo e rotação de culturas. Ambas as modalidades podem adotar o preparo da terra 
do tipo manual ou do tipo mecanizado, incluir controle de ér vas daninhas através de herbicida ou de capina com enxada.

Este tipo de cultivo é muito difícil de se empreender nas āreas de terra firme de Amazōnia devido não se ter estabelecido, ainda, sistemas de manejo capazes de tornā10 economicamente viāvel. Contudo se tem feito referéncia a algumas formas bem sucedidas de cultivo durante vários anos. BATISTA (1969) cita dois empreendimentos, um perto de Manaus e outro próximo de Belēm, os quais adotaram o desmatamento me cânico, enterrio dos galhos e fol has e queima dos tocos. Toda via não fornece detalhes sobre as operações.

Sabe-se que na região Amazônica algumas āreas tem sido cultivadas intensivamente por vārios anos com grandes adições de fertilizantes quĩmicos e utilização de mäquinas e/ ou herbicidas no controle das ervas daninhas.

SANCHEZ et alii (1982) relata uma experiência de cultivo continuo durante 8 anos, após desmatamento de uma ārea de floresta secundāria de 17 anos em Yurimaguas, na Amazônia Peruana, tendo sido, realizados 21 plantios em rotaçäo de arroz, milho e soja e obtida uma produção média de 7,8 ton/ha /ano de grãos.

o cultivo de plantas perenes é diversificado pois pode ser de monoculturas ou de cultivos em consörcio, sen do que estes podem incluir consörcio complantas de ciclo cur to ou mesmo essenciais florestais.

0 Centro de Pesquisa Agropecuäria do Trōpico Umido - CPATU - estā desenvolvendo pesquisas de consōrcio de 
vārias plantas perenes na maioria nativas da região. Uma das pesquisas consiste em substituir parcialmente o subbosque da floresta por culturas de pimenta do reino, cacau e guarana (EM BRAPA, 1981).

As atividades florestais incluem o extrativis mo e o plantio de essências florestais. O extrativismo, assim como o cultivo itinerante, desde hā muito vem sendo praticado pelo cabloco da região. Sua maior participaçãona alteração do ecossistema consistia, atē algumas dēcadas atras̄, na retirada de poucas ārvores que eram utilizadas na construção de casas. Com o crescimento de värias cidades da região, empre sas de diversos portes passaram a explorar intensamente grandes āreas.

Por outro lado, o plantio de essências flores tais é restrito à grandes empresas. Esta atividade inclui, na maior parte, o plantio homogēneo de essências nativas ou mesmo ex e Industrial.

Outras formas de exploração floresta? são 0 enriquecimento da floresta, que consiste em se abrir clarei ras alinhadas parapiantar essências nativas, e a erradicação completa com retirada de material vegetal para fabricação de papel e posterior regeneração natural. Esta ūitima forma praticamente não tem sido realizada na Amazōnia brasileira porém existem experiências realizadas por vārios organismos da Fran ça na Guiana Francesa.

A instalação de pastagens artificiais nas ter ras firmes da Amazōnia ē a atividade que mais tem contribuido 
com a alteração do ecossistema natural na América Latina (FEARNSIDE, 1979) e mesmo na Amazōnia. 0 desmatamento de 8 milhões de hectares no período de 1966 a 1979 deve-se a grandes projetos onde foram implantados extensas āreas de pastagem (MEYERS, 1982).

Todavia, a nível experimental tem-se tentado outras formas de criação de gado. Desde o inîcio da década de 70 criadores de gado no Estado do Parā utilizam o consórcio de pecuāria com cultivo de seringueira (Hevea brasiliense). Mais recentemente a EMBRAPA (UEPAE-Manaus) tem testado a implantação de pastagem sem eliminar completamente a floresta, ou seja, com desmatamento parcial.

\subsubsection{Desmatamento}

As atividades agrícolas em geral, o plantio de floresta e pastos artificiais requerem a erradicação da floresta.

0 desmatamento nas terras firmes da Amazōnia se intensificou a partir da dēcada de 60 , sob o incentivo do governo quando se instalaram grandes empresas tais como JARI, SUIA-MISSU, BRUMASA e outras. No período de 1966 a 1979 foram desmatados 8 milhões de hectares para a implantação de projetos agropecuārios incentivados pela SUDAM - Superintendência de Desenvolvimento da Amazōnia (MEYERS, 1982). O IBDF contu do, assume que até 1981 haviam sido desmatados 8 milhões de hectares de floresta densa (BAIARDI, 1983). Isto corresponde a 
$1,6 \%$ da Amazōnia legal e a $32,3 \%$ da ärea do Estado de São Pau 10 .

Considera-se que, apesar da grande intensidade de desmatamento na ūitima década, a Amazōnia ainda é um siste ma em equilibrio (SALATI e VOSE, 1984).

Existem dados que corroboram com a hipótese do crescimento exponencial do desmatamento (FEARNSIDE, 1982; BAIARDI, 1983). Contudo, BAIARDE (1983) afirma que se tal ocorresse a floresta densa da Amazōnia brasileira desaparecia atē o inîcio do prōximo sēculo.

Muito embora os dados de desmatamento sejam extremamente discutīveis, sabe-se que são derrubadas āreas de 10 mil hectares por ano em uma só propriedade (SHUBART, 1983) principalmente para a implantação de pastagens artificiais e plantios homogéneos de essências florestais.

Caso os desmatamentos continuem em grande escala como vem acontecendo ultimamente nos Estados de Rondōnia, Acre e Mato Grosso, indiscutivelmente o equilibrio ecolögico será fortemente afetado.

Na forma tradicional de desmatamento $\bar{e}$ feita a erradicação da vegetação de pequenas āreas e realizadas as operações de broca, derrubada, queimada e coivara.

A broca consiste no corte, com terçado - uma espécie de facão - das plantas do estrato arbustivo, é iniciada no fim da estação chuvosa ou início da estação seca e visa fa cilitar a derrubada das ārvores maiores. A derrubada destas $\bar{e}$ feita com o auxîlio do machado apōs o que espera-se a secagem 
dos residuos vegetais quanto então são queimados. Conforme a intensidade da queimada há necessidade de utilizar a coivara que consiste em amontoar os galhos e troncos pequenos e queimä-los visando a limpeza do terreno para o cultivo.

Contudo com a implantação de grandes projetos agropecuärios tanto o tamanho das āreas aumentaram como as técnicas de desmatamento se modificaram. Jä em 1968 no Estado do Mato Grosso em apenas um projeto 1.000 homens derrubaram a mata durante três meses e meio usando machado e foice. Atualmente são bastante comuns o uso de moto-serra e do trator para não se falar nos desfolhantes $(3,40)$ cujos os efeitos são evidentes no Estado do Acre (VALVERDE, i981).

2.3. Consequências da Alteração sobre a Mâtēria Orgānica do Solo

A matēria orgànica do solo $\bar{e}$ afetada pelas alterações do ecossistema tanto pelas mudanças climäticas decor rentes da modificação da cobertura vegetal quanto pela prōpri a natureza dos compostos orgänicos, provenientes de fitomas sa, que são adicionadas ao solo.

Serão considerados a seguir as modificações que ocorrem sobre a superficie do solo, ou seja, na fitomassa, e as mudanças no perfil do solo. 


\subsubsection{Modifica.ções na Fitomassa}

A fitomassa se modifica consideravelmente, tan to qualitativa como quantativamente, de acordo com o tipo de utilização adotado.

Inicialmente a fitomassa aērea da floresta pri märia é bastante elevada (vide item 2.1.1.) e constituî́da de dicotiledōneas.

Com a derrubada a fitomassa é reduzida a restos vegetais que podem ser queimados ou retirados total ou parcialmente dolocal. Contudo persistem na ārea sementes e ge mas dormentes que se desenvolvem logo que existam condições fa vorāveis de temperatura e umidade: é a regeneração da floresta, que por sua vez é fortemente modificada com o cultivo do solo.

As modificações com o desmatamento são drāsticas, ao contrārio da regeneração que é gradativa.

A forma de desmatamento tradicional, atravēs da queimada, transforma em um curto periodo de tempo toda a fito massa da floresta em detritos vegetais constituidos de tron cos, galhos, fragmentos de folhas, de galhos, de flores, de fru tos, carvão e cinzas.

Parte da liteira tambëm sofre combustão e torna-se dificil distinguir os restos vegetais que a constituiam e os provenientes da fitomassa.

Atē o momento não foram feitos estudos na Amazônia brasileira que indiquem a conversão da fitomassa em car 
vão e cinzas apōs a queimada. Contudo, dados sobre a quantidade desses residuos encontrados por DANTAS e MATOS (1981) após a queimada de floresta densa na Amazōnia Oriental,indicam uma quantidade de 17 ton/ha, bastante inferior a 26,8ton/ha en contrado por Silva (1978), citado Por DANTAS e MATOS (1981), no litoral do Estado da Bahia.

Os residuos vegetais, principalmente as cinzas, passam ao solo pela ação das chuvas e da atividade biologica promovendo modificações no pH e na quantidade de nutrien tes.

Quanto ā regeneração tratar-se-ā aqui de duas formas, as quais denominaremos: regeneração natural e pousio. A diferença entre elas è que o pousio corresponde à regeneração apōs o solo haver sido cultivado, nos moldes do cultivo itinerante.

A regeneração natural foi assim chamada pelo fato de não haver influência do homem após a derrubada, sendo que pode ocorrer depois que o material vegetal é queimado ou quando é em parte retirado do local com o auxílio de trato res. o primeiro caso ocorre quando por algum motivo alheio à vontade do agricultor não é possível instalar o cultivo (ante cipação das chuvas, por exemplo). O segundo corresponde à uma forma de exploração florestal do tipo papeleiro e, embora ocorra apenas em āreas experimentais (FLORESTA, 1982), é impor tante conhecer sua influéncia para melhor avaliar os benefí cios e prejuizos causados pelo fogo.

$\mathrm{Na}$ regeneração natural a vegetação reaparece alguns meses depois de derrubada, quer atravēs da germinação 
como da brotação de tocos e raĩzes. o período de tempo varia principalmente em função do inîcio das chuvas apōs a estação seca.

LESCURE e PREVOST (1979) observaram que na região da Estrada de Sta. Elie (Guiana Francesa) no ano de 1976 as primeiras plāntulas apareceram 2 a 3 meses apōs a derrubada, tanto quando o material vegetal foi queimado como quando foi transportado do local. A densidade naquele estägio era de 8 a 10 individuos $/ m^{2}$. Um ano apōs o desmatamento, havia pre ponderāncia das plāntulas sobre as brotações havendo tanto es pēcies tipicamente florestais como espēcies pioneiras (MAURI, 1979). Comparando locais que sofreram queimada com outros, i. sentos, este autor verificou que o fogo não impediu a brota ção e parecia mesmo favorecer a germinação de a lgumas plantas.

Contudo, na mesma ärea, trēs anos e meio apōs o desmatamento, a vegetação evidenciava não sō os efeitos das novas condições microclimäticas como tambēm os efeitos do fogo. Os locais onde a passagem do fogo foi intensa apresentaram re tardamento no processo de regeneração. Por outro lado, locais onde foi diminuta a ação do fogo e estavam prōximos à flores ta primāria apresentaram maior velocidade de regeneração. A fitomassa aērea nestes locais foi estimada em quase 40 ton/ha de peso seco.

As espēcies mais frequentes na regeneração são as do gēnero Cecropia. Nas pesquisas da região de Sta. Elie as espēcies deste gēnero correspondiam a $48 \%$ e $50 \%$, respectiva mente, 1 mês e meio e 6 meses apös a derrubada (FLORESTA,1982). 
Aos 3 anos as ärvores do gênero Cecropia continuavam dominan do, chegando a atingir de $10-12 \mathrm{~m}$ de altura e mais de $90 \%$ de individuos com mais de $5 \mathrm{~cm}$ de diāmetro (PREVOST, 1981a).

Por outro lado aos 6 anos o gênero Cecropia divide com o gênero Vismia a hegemonia do dominio. Dentre 283 indivĩduos com diāmetro superior a $5 \mathrm{~cm}$ existentes em $100 \mathrm{~m}^{2}, 81$ eram do gênero Cécropia ( 49 cecropia obtusa e 32 Cecropia scia dophyl1a) e 60 do gênero Vismia. Do 60 para o 70 a no ocorreudi minuição para 255 indivĩduos $/ 1000 \mathrm{~m}^{2}$, e essa diminuição deveu se sobretudo a morte de individuas das espēcies Cecropia obtusa e do gēnero Vismia. Contudo a ārea basal aumentou de 21,4 para $22,2 \mathrm{~m}^{2} /$ ha (PREVOST, 1981b).

A regeneração nos solos utilizados pelo cultivo é mais lenta que a regeneração nătural. Na Guiana Francesa a ā rea basal, obtida por LESCURE (1978) em uma ärea de pousio de 4 anos, era equivalente à encontrada por PREVOST (1981b) em $\bar{a}-$ rea de regeneração natural com 3 anos de idade.

A regeneração durante o pousio dā-se, conforme demonstraram estudos realizados em outras regióes do trópico úmidos com a colonização rápida atravēs da invasão de plantas herbāceas, formando uma fase realtivamente distinta apōs qual se instalam arbustos e ārvores heliófilas que são posteriormente substituídas (20-25 anos) poir espécies das fases mais avançadas do silvogènese (FLORESTA, 1982).

Não se dispõe, a inda, de dados referentes $\bar{a}$ quantidade de fitomassa em diferentes fases da regeneração da vegetação secundāria durante o pousio na Amazōnia. Contudo ē de se esperar, como em outras regiões tropicais, um aumento 
progressivo da fitomassa.

Com 4 anos e meio na região de Manaus a vegetâ ção atingiu $15 \mathrm{~m}$ de altura, apresentava baixa diversidade e do mināncia da espēcie Cecropia sciadophylla. (MANARINo et alij 1982 ).

Apōs 10 ou 15 anos a vegetação pode chegar a $10 \mathrm{~m}$ de altura. Com 50 anos jā apresenta um carāter tipicamente florestal sendo dificil ao observador inexperiente distinguĩ-la da floresta primāria. Depois de 100 anos, tempo estimado para renovação completa da floresta primäria, existe total semelhança florīstica e fisionōmica (SHUBART, 1983).

No al to Diapoque apōs 4 anos de pousio o estra do mais alto, constituido de Cecropia spp. e Laetria procera, chegava a $8 \mathrm{~m}$ de altura. Apös 10 anos a vegetação atingia $20 \mathrm{~m}$ e a flora era visivelmente composta de espécies florestais. Aos 30 anos atingia $35 \mathrm{~m}$ de altura (TURENNE, 1977).

Outra ārea com vegetação secundāria de 35 anos da região de Manaus apresentou dossel superior fechado com ate $20 \mathrm{~m}$ de altura onde dominavam a s espécies do gënero Goupia, Glabra e Vismia, algumas Melastomatāceas e espécies colo nizadoras em extinção tais como Cecropia sciadophylla e Purpuracea spp. os estratos intermediārios apresentavam espécies característicás de floresta primāria e algumas palmeiras (MANARINO et alii, 1982).

A evolução da regeneração todavia pode ser com pletamente desordenada caso sejam impostas outras pertubações na floresta secundāria. Quando a pressão antröpica è forte 
e continua, com utilização repetida do fogo, pode ocorrer para lização do processo com o desenvolvimento de espēcies herbáce as agressivas. Sob condições severas, o processo pode ser con duzido de uma savanização (FLORESTA, 1982; SHUBART, 1983).

A continua queima da vegetação e o cultivo do solo, segundo LIMA (1954), conduz à inversão do processo normal de regeneração propiciando a instalação de uma vegetação predominamente herbācea denominada na Amazōnia brasileira áe "macega".

\subsubsection{Modificacões no Solo}

A liteira corresponde a parte superior do perfil e tanto a sua quantidade como a sua composição influem di retamente na matēria orgānica do perfil do solo.

Sob cultivo a quantidade de restos vegetais so bre o solo é relativamente pequena ou de curta permanēncia de vido às condições de intensa decomposição e operações agrīco las.

Poucos são os dados sobre a quantidade de liteira existente sob vegetação secundāria em āreas de pousio.

No alto Rio Oiapoque, na Guiana Francesa, TUREN NE (1977) assinalou que nos dois primeiros anos de pousio a liteira. era ausente, porém, a partir do 40 ano o peso das folhas da mesma eram, em média, equivalentes ao da floresta pri märia, não obstante extremamente variāvel $\left(155 \mathrm{a} 1067 \mathrm{~g} / \mathrm{m}^{2}\right)$ de vido a prōpria heterogeneidade da vegetação. Aos 10 e 31 anos 
o coeficiente de variação é pequeno indicando maior homogene dade (TURENNE, 1977 ).

A produção da liteira varia sobretudo com o es tāgio da vegetação secundāria e as condições climāticas. Na Amazônia oriental, no perĩodo de 2,5 a 3 anos de regeneração natural foi observada uma média mensal de $567 \mathrm{~kg} / \mathrm{ha}$ o que correspondia a $75,7 \%$ da produção na floresta primāria adjacente (EMBRAPA, 1981 ).

No estudo realizado por TURENNE (1977) no alto Rio oiapoque a composição da liteira em termos de $C$ e $N$ sob floresta primāria e pousio eram idēnticas. Somente apōs 4 anos a fração fina da liteira, a esse altura bastante enrique cida de particulas minerais, apresentou-se relativamente mais rica em $N$ e consequentemente uma relação C/N mais baixa (16). Com a evolução da regeneração esta diferença tende a desapare cer (TURENNE, 1977 ).

Por outro lado, na região de Manaus, MANARINo et alij (1982) verificaram algumas diferenças entre a liteira de floresta primāria e as de floresta secundāria sob pousio. A vegetação secundāria iendeu a apresentar maiores teores de C total porém menores de C exträ̃vel e menor acidez trocāvel. Os restos vegetais provenientes da fitomassa e da liteira são incorporados naturalmente ao solo apōs o desma tamento e afetam a quantidade e mesmo a natureza da matēria orgänica do solo.

Depois do desmatamento pode-se encontrar peque nos aumentos de $\mathrm{C}$ e $\mathrm{N}$ no solo devido à combustão incompleta de 
restos vegetais e a ocorrēncia de partīculas de carvão (MILLER et alii, 1982).

No Nordeste do Estado do Parā, FALESI et alij

(1980) não encontrou diferenças estatísticas entre o teor de C de solos em äreas cultivadas e solos de floresta primária.

Em Yurimaguas, na Amazōnia peruana, SANCHEZ et alij. (1982) assinalam que em 8 anos de cultivo intensivo, utilizando adubação mineral e rotação de cultura, houve decrésci mo do total de C praticamente apenas no primeiro ano.

Na Guiana Francesa não foram observadas dife renças marcantes no teor de $C$ total do horizonte superficial nos dois primeiros anos após o desmatamento (cultivo seguido de 1 ano de pousio), em relação à floresta primāria, em dois locais, mesmo sob regimes hidricos diferentes. Onde havia impedimento de drenagem no horizonte $B$ e um pequeno periodo seco, embora existissem elevados teores de C, não ocorreu varia ção. O mesmo aconteceu sob condições de melhor drenagem, au sência de Mẽs ecologicamente seco (limite de $30 \mathrm{~mm}$ ) e menores teores de C (TURENNE, 1977).

Ao contrārio, entre Sinnamary e Sta. Elie, Betsch et alii (1981) citados por TURENNE (1982) verificaram uma diminuição no teor de C nos $3,5 \mathrm{~cm}$ superiores do solo, após o desmatamento, tanto sob condição dé drenagem livre do solo como de drenagem impedida.

TURENME (1977) verificou que durante värios anos de pousio o teor de $C$ no horizonte superficial tendeu a diminuir, não havendo recuperação mesmo após 31 anos. Por ou- 
tro lado, nos horizontes subsuperficias ocorreu diminuição desde o primeiro ano, por ocasião do cultivo.

o teor de $N$ total diminui logo apōs o desmatamento, tanto na superficie como em profundidade, elevando a relação C/N. Depois, durante o pousio, os valores da relação C/N ficam semelhantes aos da floresta (TURENNE, 1977). A dimi nuição do teor de $N$ após o desmatamento tambēm foi constatada por TURENNE (1982).

No estudo realizado na região de Manaus (MANARINO et alii, 1982) os solos da ārea em pousio tambēm apresen taram uma relação $C / N$ ma is elevada no horizonte superficial tendo decrescido menos bruscamente com a profundidade na ārea de 4 anos, que na de 35 anos de pousio.

SANCHEZ (1976) considera que o cultivo itine rante não reduz para menos que $75 \%$ o nîvel de matéria orgânica existente em equilibrio na floresta.

A quantidade de matēria orgānica leve não humi ficada è muito pequena ( 1 a $2 \%$ do C total) tanto no solo de floresta primäria, quanto no solo sob pousio (MANARINO et alii 1982).

A fração extraîvel do humus pouco se modifica com o cultivo (TURENNE, 1977) Ou com o pousio (TURENNE, 1977; MANARINO et ali i, 1982). Por outro lado os diversos componentes da fração extraĩvel variam depois do desmatamento quer com o cultivo quanto com o tempo de pousio.

Após o desmatamento TURENNE (1977) verificou que na sequéncia cultivo-pousio ocorria uma diminuição marcan 
te na quantidade de àcidos fülvicos livres e ligados na super fície do solo, sem um correspondente aumento no teor de ácidos hūmicos. 0 mesmo não ocorreu nos horizontes subsuperficiais $(50 \mathrm{~cm})$ os quais desde o inīcio praticamente só conti nham àcidos fūlvicos.

A mesma diminuição foi observada por MANARINO et alii (1982) em solo de 4 anos de pousio, sendo que na superfície ocorreu um aumento relativo na quantidade de äcidos hūmicos e em profundidade ele estava completamente ausente. Verificaram ainda que as modificações, causadas pelo desmata mento no fracionamento do humus tendem a desaparecer com 0 tempo de pousio.

As frações ligadas (ācidos hūmicos e àcidos fül vicos) sendo mais estāveis tendem a desaparecer com 0 tempo de pousio enquanto a fração livre l(ācidos fūlvicos) tendem a aumentar (TURENNE, 1977 ).

0 aumento da quantidade de ācidos fūlvicos ē a companhada da diminuição da relação $C / N$ o que levou TURENNE (1977) a concluir que o aparecimento dos ácidos fūlvicos estā ligado a dinâmica do $N$.

Finalmente, TURENNE (1977) considera que duran te um curto período apōs o desmatamento ( 1 ano), corresponden te ao cultivo, ocorre uma policondensação de ácidos hümicos. A partir desse período ( 20 ano em diante) hà um aumento na quantidade de àcidos fūlvicos provavelmente às custas dos āc dos hümicos ou humina. De outro la do MANARINo et alii (1982) justificaram o aumento da quantidade de àcidos fūivicos nos so 
los sob pousio com a presença de precursosres que migram após a decomposição da liteira, paralelamente à incorporação de matēria orgânica e concentração da atividade biológica ao nível do solo, em consequência do desmatamento.

Os microrganismos são os principais responsäveis pela decomposição da matēria orgânica.

A biomassa microbiana pode ser determinada atra vēs da diferença da quantidade de $\mathrm{CO}_{2}$ produzida entre uma amos tra de solo esterilizada e incubada, e outra amostra não esterilizada (JENKINSON e POWLSON, 1976).

Em āreas onde a derrubada da floresta incluiu a queimada foram observadas quantidades de microrganismos tão elevadas (BETSCH, 1979) ou mesmo maiores (SANTOS e CRISI, 1981) que na floresta primāria.

A queimada exerce pelo menos inicitimente um efeito benéfico à atividade da microfrora o que provavelmente. estā relacionado ao aporte de grandes quantidades de nutrien tes (BETSCH, 1979). Estes efeitos se prolona durante os primei ros meses de regeneração natural (SANTOS e CRISI, 1981).

Mesmo com desmatamento sem queimada SANTOS

e

CRISI (1981) observaram aumentos na biomassa microbiana em relação à floresta primāria na Amazōnia Central, não tendo sido verificado o mesmo na Guiana Francesa (BETSCH, 1979).

CERRI et ali (1983) observaram na Amazōnia Ori ental que enquanto na fioresta primäria a biomassa microbiana do solo se restringe aos primeiros $25 \mathrm{~cm}$ do solo, após a queimada passa a se concentrar entre 10 e $20 \mathrm{~cm}$. Sob pousio de cur 
ta duração ( 3 anos) se apresentou em quantidade um pouco menor que no solo sob floresta porém ocorria em maior profundidade $(30-40 \mathrm{~cm})$.

Há portanto maior taxa de decomposição nas áreas em curto período de regeneração do que na floresta primäria além do que naquelas āreas hã evidências da participação de invertebrados na degradação da matēria orgānica, nos primeiros centimetros do solo (SANTOS e CRISI, 1981).

Muito embora existam diferenças na quantidade e distribuição da biomassa microbiana, causadas pela queimada, não ocorrem no início (10 ano) diferenças marcantes nos tipos de bactérias encontradas o que BETSCH (1979) atribuiu à manu terição do teor de matéria orgânica e nutrientes do solo, alēm do mecanismo de proteção das bactērias. Contudo, após esse 0 perĩodo inicial verifica-se a eliminação parcial de algumas es pécies e o aparecimento de outras.

2.4. Implicações Ecolōgicas e Agronōmicas

Existem vārias implicações ecolōgicas e agronōmicas, causadas pelo desmatamento e utilização agrî́cola, que se encontram vinculadas às modificações da matēria orgânica. Dentre elas abordaremos a transferència de c para a atmosfera, a conservação e a fertilidade do solo. 


\subsubsection{Transferência de Carbono para a Atmosfera}

A quantidade de carbono existente na biomassa das florestas do planeta $\left(83 \times 10^{10}\right.$ ton) equivale praticamente a quantidade existente na atmosfera $\left(70 \times 10^{10}\right.$ ton). 0 so10, por outro 1ado, armazena de 117 a $217 \times 10^{10}$ ton (SALATI, 1983), portanto quantidade equivalente a contida na biomassa e na atmosfera juntas.

Com a eliminação da floresta parte do C exis tente na fitomassa è transferido para a atmosfera.

A floresta amazōnica è a maior, mais complexa e mais cobiçada floresta do globo (SALATI, 1983). E tambēm o ū timo reduto das grandes florestas tropicais ainda relativamen te intacto (VALVERDE, 1981).

SALATI (1983), considerando uma quantidade de 320 ton/ha de C (200 toneladas na parte aérea e 120 toneladas no solo) estima a existência de $19,2 \times 10^{10}$ ton desse elemento na bacia amazónica (600 milhões de ha). Somente o carbono armazenado na parte ärea equivale, segundo os dados apresentados, a $12 \times 10^{10}$ toneladas, $14 \%$ da biomassa de todas as florestas e $17 \%$ do carbono da atmosfera do planeta.

Quanto se realiza a queimada, a maior parte do $C, S$ e $N$ existente na fitomassa érapidamente transferida,por volatilização, para a atmosfera (MILLER et alii, 1982). Caso a derrubada não inclua a queimada hà uma transferēncia mais lenta, através da decomposição da matēria orgānica, para a atmosfera e para o solo. 
As queimadas, portanto, contribuem, juntamente com a queima de combustiveis fósseis, para o aumento da quantidade de $\mathrm{CO}_{2}$ na atmosfera do planeta a qual vem crescendo a uma taxa de 1,5 ppm por ano,com tendēncias à incrementos na razão de 3 a $5 \%$. Com este aumento prevé-se o aquecimento da terra com reflexos na variação das zonas climáticas, afetando, consequentemente, a agricultura. Outro efeito provável ē o au mento do nível dos oceanos (SALATI, 1983), em consequência do degelo das calotas polares.

Outras consequências prejudiciais ao equilíbr o dos ecossistemas amazōnicos poderão ser causadas pelo desma tamento: redução da precipitação pluviométrica, aumento dos perĩodos de estiagem, dêficit de àgua no solo, maiores oscila ções de temperatura (SALATI, 1983), destruição dos estoques genéticos e modificação do solo (SHUBART, 1983).

Contudo, apōs o desmatamento, a vegetação secundāria que se instala, por estar em franco crescimento, incorpora mais $C$ do que o elimina atravēs da respiração (BAIARDI 1981). Este fato ocorre normalmente mesmo sob condições natu rais devido à queda de árvores que abrem clareiras, onde as modificações do ecossistema são drāsticas, embora localizadas (SHUBART, 1983 ).

2.4.2. Conservação do Solo

A queimada acarreta pequenos efeitos na matéria orgānica do solo (SEUBERT et alii, 1977). Durante a com - 
bustão raramente a temperatura e superior a $100^{\circ} \mathrm{C}$ a $1 \mathrm{~cm}$ de profundidade e à $50^{\circ} \mathrm{C}$ à $2 \mathrm{~cm}$ (EWEL, et-al ji , 1987).

Contudo a retirada da cobertura vegetal expõé o solo à ação direta da intempérie possibilitando processos e rosivos, tanto pelo arraste dos horizontes superficiais como pela destruição dos agregados com o impacto das chuvas, cau sàndo compactação.

Na região de Sta. Elie, a uma declividade de $12 \%$ onde sob floresta a erosão era de 0,5 ton/ha, após 0 desmatamento chegou até 45 ton/ha, diminuindo posteriormente, quan do da implantação de pastagem, com a cobertura do solo, para valores prōximos ao encontrato sob floresta (SÁRRAILH, 1982).

Um ano depois do desmatamento a temperatura do ar, medida às 12 horas, aumentou de $4{ }^{\circ} \mathrm{C}$ à sombra $\left(26^{\circ} \mathrm{C}\right.$ a $\left.30^{\circ} \mathrm{C}\right)$ e $6^{\circ} \mathrm{C}$ ao sol (31 a $37^{\circ} \mathrm{C}$ ) (MAURI, 1979).

DINIZ e BASTOS (1980) constataram na região de Belēm que a temperatura do solo desprovido de vegetação era sempre maior que no solo sob floresta, mesmo em profundidade $(100 \mathrm{~cm})$. As diferenças foram maiores nos primeiros $20 \mathrm{~cm}$ e nos meses de menor precipitação pluviomētrica (diferença de $11,8^{\circ} \mathrm{C}$ no mês de outubro às $15 \mathrm{hs}$ ).

No s010 sob vegetação em regeneração, aproximą damente 1 ano e 4 meses depois da queimada, a temperatura é maior, ate $10 \mathrm{~cm}$ de profundidade, que na ārea onde a vegetação foi apenas derrubada e sob a floresta primāria adjacente (SANTOS E CRISI, 1981). 
0 regime hidrico se altera devido a maior quan tidade de àgua que não é interceptada e se infiltra no solo, causando lixiviação. WOLFRAN et a lii (1982) verificaram que à floresta interceptou $20 \%$ do total da precipitação.

Todavia, esses efeitos são acentuados ou mesmo eliminados à medida que a vegetação secundária se instala pro tegendo o solo.

observa-se que o solo em ārea de pousio de cur ta duração ( 4 anos) na região de Manaus apresenta melhor dis tribuição da matéria orgãnica com maior quantidade de ácidos hümicos na superficie que o solo sob floresta primäria (MANA.RINO et aIii, 1982 ).

Por outro lado a atividade biológica mais intensa causa aumentos na macroporosidade (CHAUVEL, 1982) poden do favorecer, com o aumento da drenagem, a transiocaçãa de a gila e a remoção de nutrientes.

A medida que o tempo de pousio aumenta o solo retorna as condicões iniciais. Apōs 35 anos de pousio o solo apresenta pequenas diferenças em relação ao da floresta, como é o caso da porosidade (MANARINO et ali i, 1982).

o desmatamento com trator afeta drasticamente o solo. A lámina remove totalmente a liteira e grande parte dos horizontes superficiais onde se encontram a maior parte da matêria orgānica e dos nutrientes. A pressão das rodas causa compacíą̧ão.

$\mathrm{Na}$ região de Sta. Elie, nos locais mais compac tados pelas rodas do trator, após 1 ano ainda não havia vegetação (MAURI, 1979). 
SEUBERT et alii, 1977 verificaram aumentos de 10 a $18 \%$ na densidade do solo em uma ārea onde a floresta foi eliminada com trator, em comparação com a que havia sido que mada.

2.4.3. Fertilidade do Solo

A matéria orgānica è um dos principais contribuintes da fertlidade dos solos da Amazōnia especialmente nos solos de terra firme que, na maioria,possuem fração mineral ativa com baixa capacidade de retenção de cātions.

A matēria orgānica é responsāvel em parte pela retenção de cātions além de liberar, atravēs da decomposição, os diversos nutrientes.

Segundo Nicholaides et alii (1982) citados por MILLER et alii (1982) a matéria orgānica pode melhorar diversos fatores limitantes que afetam grande parte dos solos da bacia amazōnica, tais como deficiência de N, P, S, K, Ca, Mg, Zn e Cu, toxidez de aluminio, baixa capacidade de troca de cátions e riscos de erosão.

Segundo DABIN (1982) tantio os fatores fisicos quanto os fatores quimicos da fertiliuade do solo apresentam correlações com o carbono total e os equilitbrios das frações hụmicas.

Melhor distribuição da matēria orgānica e aumento do teor de àcidos hümicos podem ocorrer na superfície do solo apös o desmatamento (MANARINo et alii, 1982) porēm não 
estä claro porque ocorre e em que condições.

Em estudos realizados na Âfrica (Costa do Marfim) a melhoria da estrutura do solo correspondeu a modiftea ções qualitativas do humus. Os ācidos hümicos extraidos pla soda apresentaram, na estação de Adiopodoumé, na Costa do Mar fim, correlação positiva com a estrutura, ao conträrio dos $\bar{a}-$ cidos fūlvicos (DABIN, 1982).

De uma forma geral o teor de carbono estä correlacionado positivamente com os fatores quimicos da fertilidade do solo. E o caso do N total, do teor de cátions trocáveis e do $p$ total (DABIN, 1982).

As diversas frações do humus, entretanto, possuem correlações diversificadas com os citados fatores.

Em uma revisão sobre a relação e a evolução dos compartimentos hūmicos sob cultura DABIN (1982) destaca que no Togo (1000 a $1200 \mathrm{~mm})$ e no Alto Volta (área irrigada) ha*via correlação positiva entre a humina (\% relativa) e os teores de cátions trocáveis, principalmente Ca e $\mathrm{Mg}$.

A porcentagem relativa de humina e os ācidos hümicos (soda) estäo frequentemente correlacionados positivamente com o P total enquanto O P assimilável pode estar corre lacionado positivamente tanto com ācidos fülvicos livres como com ācidos hümicos (soda) (DABIN, 1982).

Inexistem, atē o momento, dados tentando corre lacionar a qualidade da matéria orgānica com os fatores químí cos da fertilidade dos solos cultivados ra Amazönia. 
Todavia, experiẽncias realizadas em Yurimaguas mostraram resultados animadores com cultivo intensivo, usa $\underline{\underline{n}}$ do adubo mineral e rotação de cultura. A matēria orgánica decresceu inicialmente (10 ano), na superficie $(0-15 \mathrm{~cm})$ e de pois se manteve estável, enquanto a capacidade de troca de cátions quase dobrou $\left(2,78\right.$ para $\left.5,51 \mathrm{mE} / 100 \mathrm{~cm}^{3}\right)$. Em oito anos de cultivo foi obtida uma produção média de 7,8 ton/ha de grãos (SANCHEZ et alii, 1982).

A aplicaçäo de "mulch" (resïduos de soja, mi1ho, arroz, amendoim e capim coloniãol tiveram efeitos muito variāveis na produção embora favorecessem a densidade do so 10. A excessiva umidade do solo causada pelos residuos, os de milho particularmente, reduziram a produção (MILLER et alii, 1982).

A produtividade obtida com a utilização de com posto ("Kudzu" e "corn stover"), em comparação à obtida com adubo inorgânico, reduziu lentamente com a continuidade do

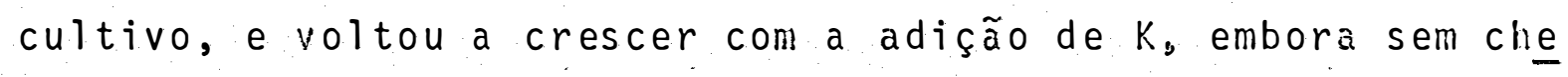
gar as produções iniciais (MILLER et alii, 1982). 
3. MATERIAL E METODOS

3.1. Caracterização do Meio Físico 3.1 .1 . Localização

o estudo foi desenvolvide na Amazōnia oriental, Nordeste do Estado do Parā, microregião homogēnea 22 deño minada Guajarina (Fundação IBGE, 1968), Municīpio de Capitão Poço, trecho compreendido entre as calhas do rio Guamá e seu afluen te, rio Irituia, nos Campos Experimentais do Centro de Pesqui sa Agropecuāria do Trōpico Omido (EMBRAPA) e PLANALSUCAR. Referidos campos experimentais estão situados na estrada PA-242 que Iiga a cidade de Irituia a cidade de Capitão Poço, respec tivamente, a 14 e 16 quilometros destas (Figura 1).

3.1.2. C1 ima

o clima da Região Amazōnica é quente e possui vārios regimes de umidade, sendo que o Nordeste Paraense apre 


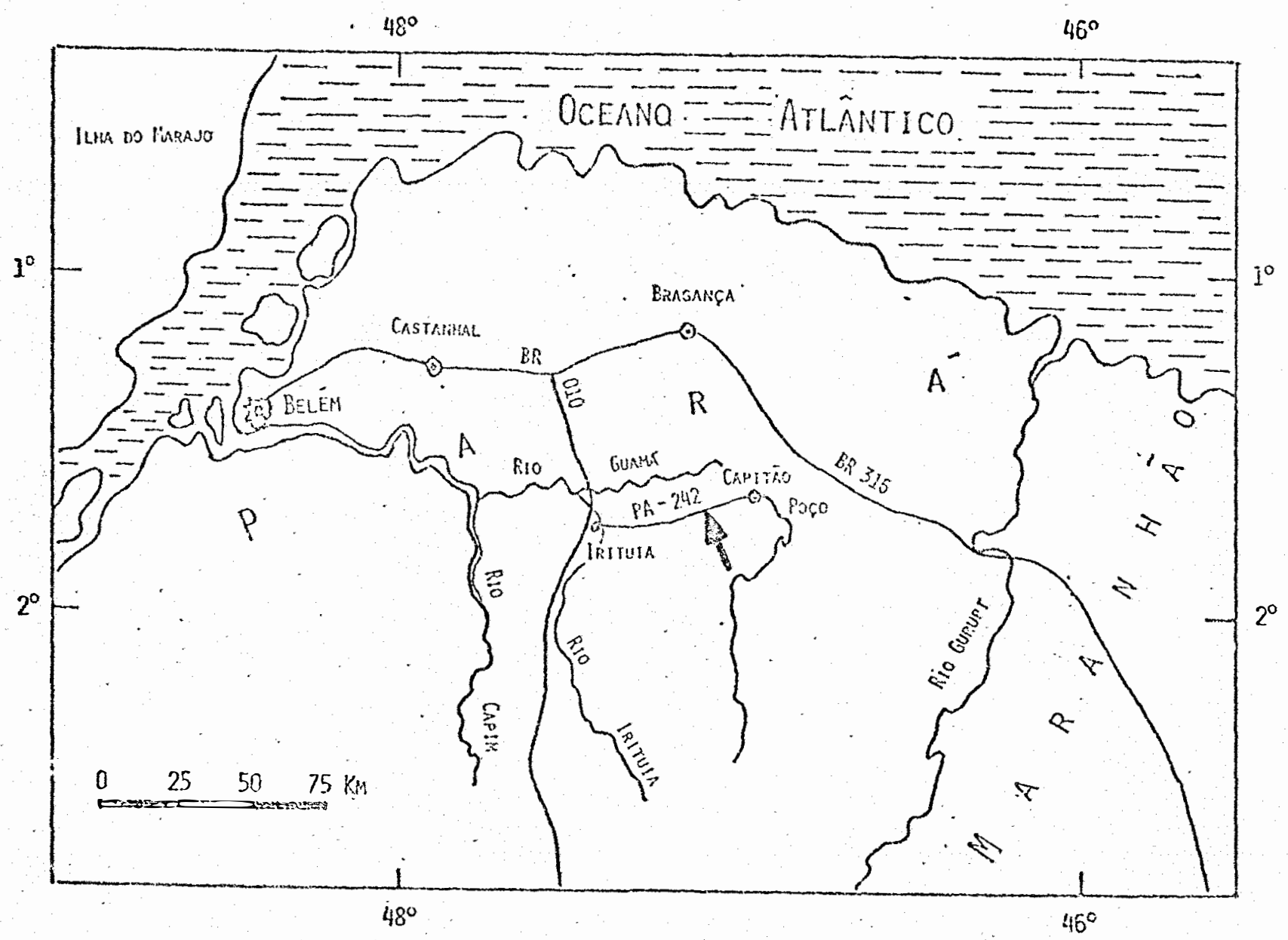

Figura 1. Indicação do local do estudo.

senta, na maior parte, subdominio climätico ümido com 1 a 2 meses secos (NIMER, 1977).

$\mathrm{Na}$ microregião Guajarina as chuvas se iniciam no fim de novembro ou inīcio de dézembro e são mais frequentes a partir de janeiro (Fundação IBGE, 19008). Segundo REGo et alij (1973), o municipio de Capitão Poço possui precipita ção normal anual em torno de $2.500 \mathrm{~mm}$, sendo o período mais chuvoso o de janeiro a junho, onde março e o mès mâis chuvoso 
(423 mm) e outubro o mais seco (45 im); a temperatura mēdia anual è de $26,9^{\circ} \mathrm{C}$, com amplitude de variação entre o més mais quente (julho) e o mais frio (janeiro), na ordem de $2,4^{\circ} \mathrm{C}$, en quadrando-se,portanto, no tipo climático Ami da classificação de Koppen.

A Figura 2 mostra o balanço hỉdrico do municīpio de Capitão Poço, segundo REGo et alij (1973).

\section{$3 \cdot 1 \cdot 3$. Vegetação}

A vegetação primāria da microregião Guajarina é de floresta, que nas āreas de terra firme corresponde à Flo resta Perenifōlia Higrö́fila Hileiana Amazōnica (KUHLMANN,1977), ou Floresta Ombröfila de Baixo Plató com cobertura de emergen tes (GOES FILHO et alii, 1973).

A região do estudo se apresenta na maior parte ocupada por Floresta Secundāria Latifoliada e atividades agro pecuārias, pertencendo, segundo GOES FILHO et alii (1973), à Região da Floresta Densa, sub Região dos Baixos Platós do Parā/Maranhão, Area alterada da zona Bragantina. Contudo,possui āreas remanescentes com vegetação de Floresta Densa de terra firme, com ärvores emergentes e estrato inferior aberto (EMBRAPA, 1981) onde, segundo DANTAS et alij (1980), as espëcies de maior frequência são Eschweilera odora. (matamatā branco) Theobroma subincanum (cupuī), Eschweiliera amara (matamatā ver melho), Apeiba burchelli. (pente de macaco), Protium decandrum (breu vermelho) e Tetragostris altisima. (breu grande). 


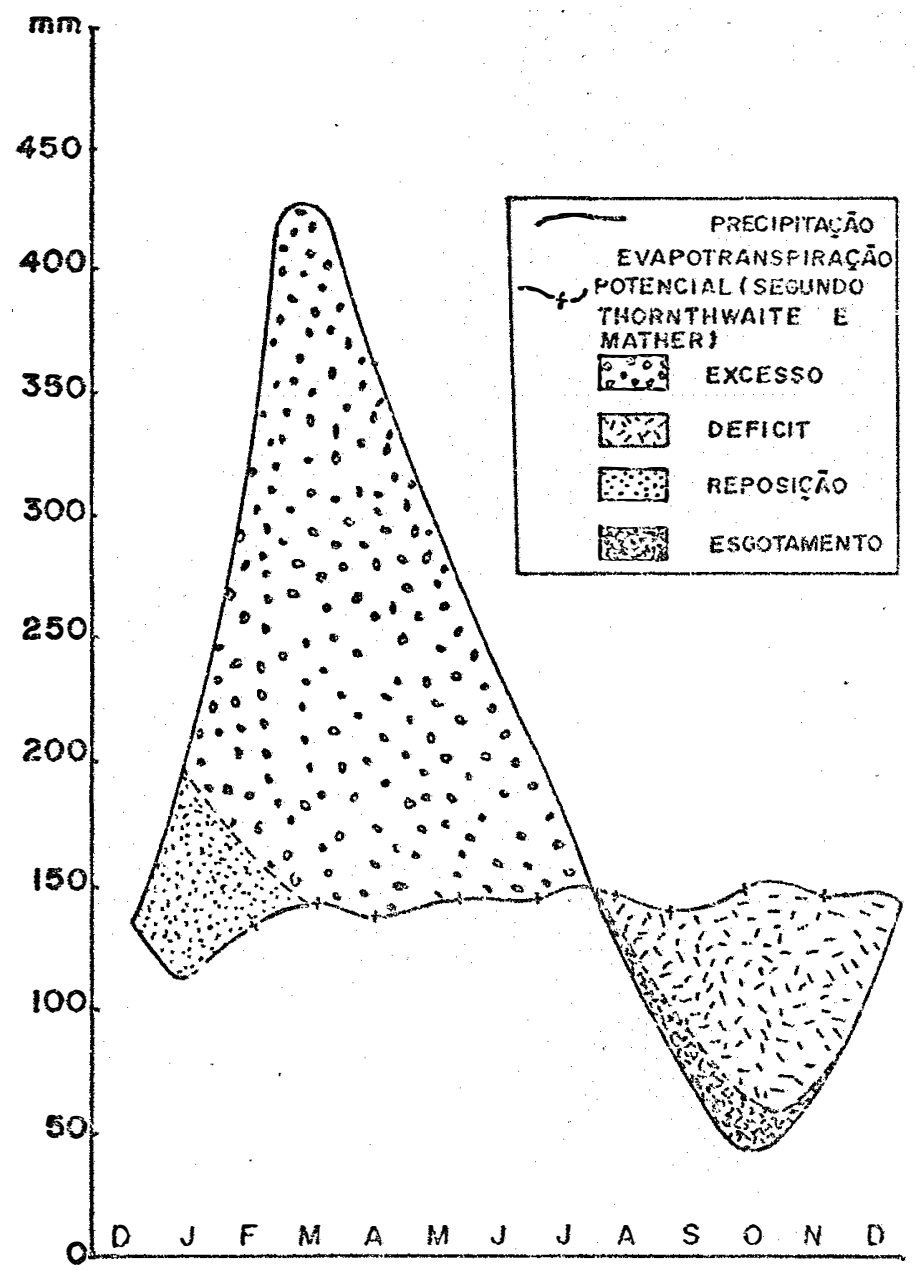

Figura 2. Balanço hïdrico do Municïpio de Capitão Poço - PA (REGO et alii, 1973). 


\subsubsection{Geomorfologia e Relevo}

o local estudado estā inciuído na unidade morfoestrutural e morfoclimática do Planalto Rebaixado da Amazōnia, que exibe superficies pediplanadas com aplainamentos em retomada de erosão recente elaborado em rochas sedimentares (BARBOSA E PINTO, 1973).

Apresenta topografia horizontal com desnivelamentos pequenos sendo o relevo considerado plano (REGo et alii, $1973)$.

3.1.5. Geologia

0 local estudado se encontra próximo a ārea de contato entre o Pré-Cambriano Indiviso e o Terciário Mēdio/ Superior (FRANCISCO et alii, 1971). Está incluido na ārea de Ocorrência da Formação Barreiras onde as rochas se apresentam na forma de sedimentos clásticos mal selecionados, variando de siltito a conglomerado e ocorrem arenitos brancos e róseo-a vermelhado, de granulação variada além de leitos de argila cre me e lentes de caolim (NUNES et alii, 1973). Contudo, por estar próximo a área de contato os processos de rebaixamento do planalto propiciaram a ocorrēncia de sedimentos inconsolidados atuais e subatuais do Quartenārio antigo e recente (REGO et alii, 1973) onde estão presentes minerais primārios pouco resistentes. 


\section{1 .6 . Solos}

Segundo ARAOJO et a Ti (1973) a parte do ?lanalto Rebaixado da Amazônia que inclui o locai estudado pos sui as seguintes unidades de solos: Latossolo Amarelo textura média, Latossolo Amarelo cascalhento e Areia Quartzosa.

REGO et alii. (1973) constataram, em locais próxi mos ao deste estudo, a ocorrência de Latossolo Amarelo textura mēdia, Concrecionārio Laterītico,Grey Hidromörfico e Latos solo Amarelo Podzolizado.

No local estudado, morfologicamente, o solo pos sui horizonte $B$ latossólico que se apresenta com características podzólicas, especialmente nos pedons de textura má is argilosa.

3.2. Descrição das Condições do Ecossistema

0 estudo foi realizado em um ecossistema natural e em um ecossistema alterado. Este encerra vārios tipos de modificações causadas pelo desimatamento e pelo cultivo e $\bar{e}$ adjacente àquele.

3.2.1. Ecossistema Natural

0 ecossistema natural possui vegetação de floresta primāria, com mais de 1.000 espēcies por hectare, cons- 
tituida de ärvores emergentes com fuste maior que $20 \mathrm{~m}$, estra to superior dominado por plantas com altura em torno de $10 \mathrm{~m}$, sendo de maior frequéncia a espēcie Euchweilera odora (matamâ. tá branco).

De acordo com DANTAS et alij (1980), baseadoem estudos de parte deste ecossistema, a maior densidade de plan tas estā na classe com menos de $2 \mathrm{~m}$ de altura (47\%) sendo de maior ocorrēncia, nesta classe, a espēcie Bauhinia guianensis. Aubl., havendo entretanto, grande diversidade (mais de 70 espécies com apenas um indivî́duo por hectare). A diversidade $\bar{e}$ maior na classe de ärvores com mais de $30 \mathrm{~cm}$ de circunferên cia $(64 \%)$, as quais somanm mais de 500 espécies por hectare.

A liteira se apresenta subdividida em dois estratos ou camadas que, adotando-se a nomenclatura proposta por Babel (1971), citado por TOUTAIN (1981), podem ser designados como: L, liteira inteira e pouco modificada e F, liteira frag mentada.

0 estrato L é mais superficial, possui de 1 a $3 \mathrm{~cm}$ de espessura e constitui-se de folhas e galhos que ainda guardam sua estrutura original. Abaixo deste está o estrato F (2 a $4 \mathrm{~cm}$ ) que mantém contato com os horizontes minerais e é constituĩdo de fragmentos vegetáis, em vārios estágios de de composição, e raizes vivas que penetram e se nutrem diretamen te do material em decomposição, alēm de se prolongarem para o interior do solo.

o solo no ecossistema natural possui pedons de diferentes classes de drenagem. Para efeito de caracterização 
tomou-se três āreas de $900 \mathrm{~m}^{2}$ correspondentes a trēs pedons pertencentes as principais classes de drenagem que ocorrem: Pedon Imperfeitamente Drenado, Pedon Moderadamente Drenado e Pedon Bem Drenado. A designação das classes de drenagem foi estabelecida em função das características morfológicas e não deve ser tomada como a diferença exclusiva entre os pedons, mas como o caräter dominante. No apēn dice se encontra a descrição dos perfis correspondentes a cada um dos referidos pedons e na figura 3 a representação esquemāti ca da sua parte superior.

\subsubsection{Pedon Imperfeitamente Drenado}

Neste pedon a liteira possui maior quantidade de galhos no estrato $L$ que corresponde a $84 \%$ do peso total da liteira. A parte composta de folhas é relativamente uniforme em quantidade enquanto a constituĩda de galhos é bastante variāvel devido a ocorrência de galhos mais pesados em algumas partes.

0 estrato $F$ apresenta-se constituído de quantidades idēnticas entre raízes vivas, fragmentos de folhas e frutos, sendo maior a quantidade de fragmentos de galhos.

Este pedon possui um horizonte misturado com 2 $\mathrm{cm}$ de espessura, designado $\mathrm{F}_{\mathrm{A}} \mathrm{Al}_{1}$, constituido de uma parte organomineral idēntica a do horizonte $A_{1 l}$ e uma parte orgänica idēntica a do estrato F.

0 horizonte All possui $4 \mathrm{~cm}$ de espessura, cerca de $5 \%$ (em peso) constituido de partes vegetais, incluindo raízes em menor quantidade e fragmentos de folhas e galhos em 


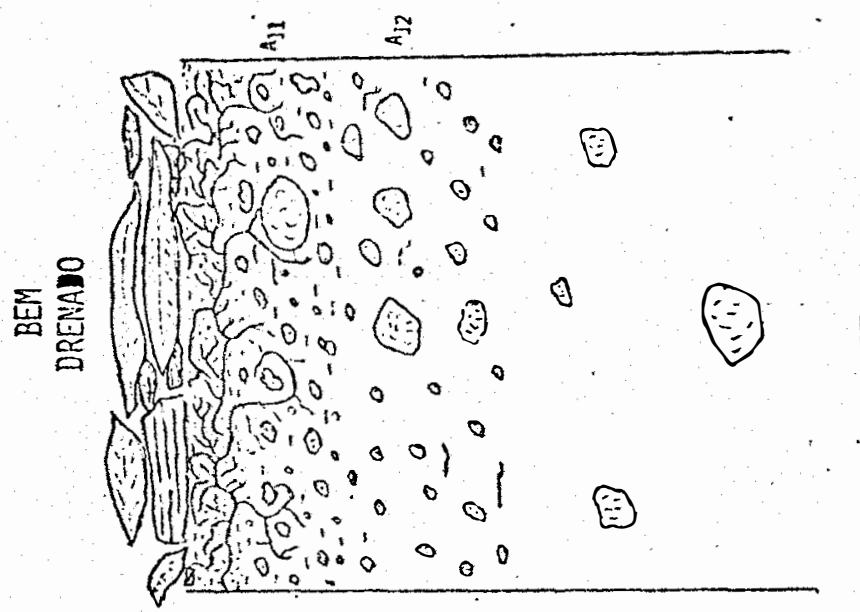

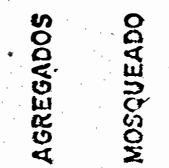

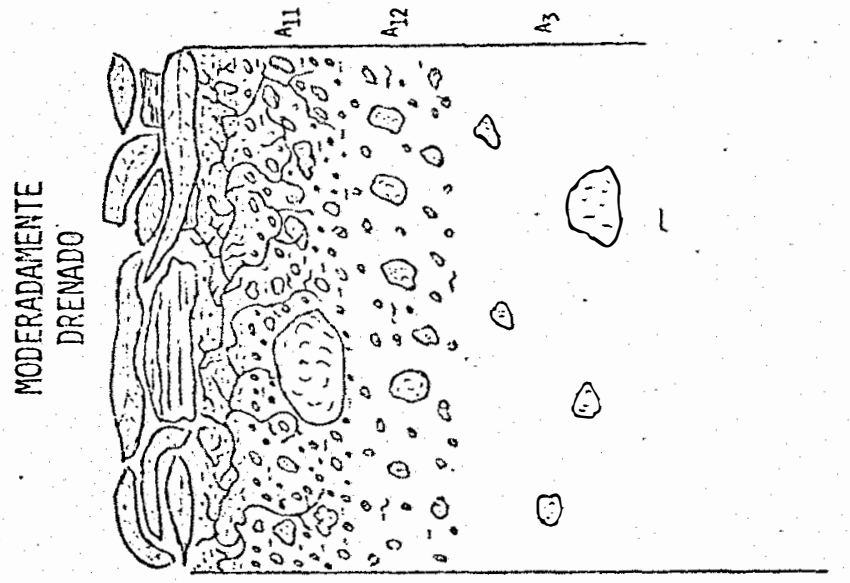

$\left[\begin{array}{l}8 \\ 0 \\ 0 \\ 0 \\ 0\end{array}\right.$

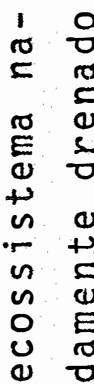

ص

$\begin{array}{llll} & 0 & 0 & 0 \\ 0 & 0 & 0 \\ 0 & 0 & 0 \\ 0 & 0 & 0 & 0 \\ 0 & 0 & 0\end{array}$

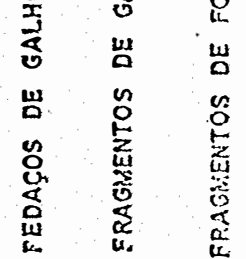

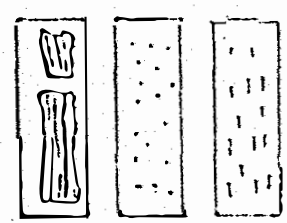

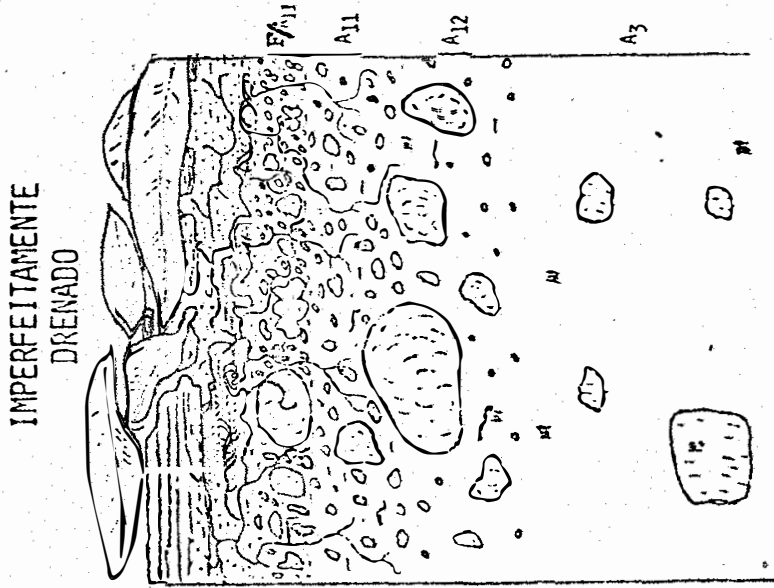

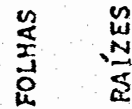

in ô

ป

i 2

2

1)

(s)

c)

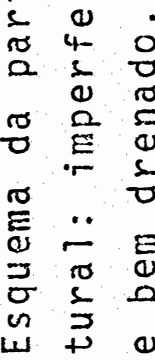

m

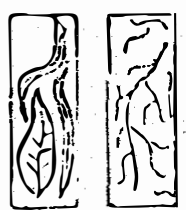

0
5
0
0
1

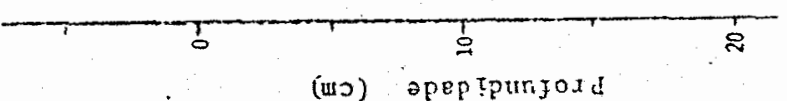


quantidades equivaientes. A parte mineral ë composta de $90 \%$ de agregados e $10 \%$ de areia em grãos simples. A cor dos agregados é bruno (10YR 4/4) e bruno amarelado escuro (10YR 4/4) e a areia bruno muito claro acinzentato (10YR 7/3). Os agrega dos possuem textura franco arenosa, são na maioria de 0,2 a $2 \mathrm{~cm}$, tipo granular, ocorrendo agregados compostos, oriundos provavelmente da coalescéncia de grumos, produto de atividade animal.

0 horizonte $\mathrm{A}_{12}$ tem $4 \mathrm{~cm}$ de espessura, quantidade bem menor de partes vegetais constituídas principalmente de raizes. A parte mineral é composta de $60 \%$ de agregaios e $40 \%$ de areia em grãos simples. A cor dos agregados é bruno (10YR 5/3 e 10YR 4/3) e da areia bruno muito claro acinzentado (10YR 7/3). Os agregados tem textura areia franca, são de 0,1 a $4 \mathrm{~cm}$, tipo broco subangular.

0 horizonte $\mathrm{A}_{3}$ possui $8 \mathrm{~cm}$ de espessura cor bruno amarelado $(10 Y R 5 / 4)$ com mosqueados pequeno e distinto, bruno forte $(7,5 Y R$ 5/8), textura franco argilo arenosa e estrutura fraca em blocos subangulares.

\subsubsection{Pedon Moderadamente Drenado}

A liteira neste pedon possui maior quantidade de folhas que de gainos no estrato L que corresponde a cerca de $90 \%$ (em peso) da mesma. A parte composta de folhas è mais uniforme e maior que a da ārea com perfil imperfeitamente drenado, enquanto a constituîda de galhos é ainda mais variāvel e menor. 
0 estrato $F$ é composto de $5 \%$ de raízes de 2 a $5 \mathrm{~mm}$ e $95 \%$ de fragmentos, sendo que os fragmentos são, namaior parte, menores que $1 \mathrm{~cm}$ e os fragmentos de galhos estãoem maior quantidade que os de folhas.

0 horizonte $\mathrm{A}_{1}$ ) possui $4 \mathrm{~cm}$, cerca de $3 \%$ (em peso) constituído de partes vegetais, sendo que estão em maior quantidade, as raízes e os fragmentos de folhas, e em menor, os fragmentos de galhos e frutos. A parte mineral é constituí da de $80 \%$ de agregados e $20 \%$ de areia em grãos simples cujas cores são idênticas as da ārea com perfil imperfeitamente drenado. Os agregados possuem textura franco arenosa, variam de 0,1 a $3 \mathrm{~cm}$, sendo a maioria menor que $0,2 \mathrm{~cm}$, também do tipo granular, e com ocorrēncia de agregados coalescentes, po rém em menor quantidades que no pedon anteriormente descrito.

0 horizonte $A_{12}$ possui $4 \mathrm{~cm}$ de espessura e muito pouca quantidade de fragmentos vegetiais. A parte mineral é constituída de cerca de $50 \%$ de agregados, na maioria de tamanho superior a $2 \mathrm{~mm}$, e $50 \%$ de areia em grãos simples. A cor e a textura são idënticas ao do horizonte correspondente no pedon imperfeitamente drenado, porëm a estrutura é granular.

0 horizonte $\mathrm{A}_{3}$ possui cerca de $7 \mathrm{~cm}$ de espessu ra, cor bruno amarelado $(10 Y R 5 / 6)$, sem mosqueado, textura franco argilo arenosa e estrutura fraca em blocos subangulares. 


\subsubsection{Pedon Bem Drenado}

No pedon bem drenado a liteira possui quantida des aproximadas de folhas e galhos, sendo que os galhos ocorrem com menor variação que nos outros pedons, em maior quantidade que no pedon moderadamente drenado, e em menor que no pedon imperfeitamente drenado. Por outro lado, a quantidade de foThas é maior que nos demais pedons, sendo que, juntamente com os galhos, formando o 10 estrato, corresponde a $80 \%$ (em peso) da liteira.

0 estrato $F$ possui menos raizes que fragmentos vegetais. As raízes väriam de 2 a $10 \mathrm{~mm}$.

O horizonte $A_{11}$ possui $4 \mathrm{~cm}$ de espessura, apro ximadamente $3 \%$ (em peso) de partes vegetais sendo que as ra zes estão presentes em maior quantidade. A parte mineral se compõe de $50 \%$ de agregados de 0,1 a $2 \mathrm{~cm}$ e $50 \%$ de areia em grãos simples. A cor é jeentica a do horizonte $A_{1}$ dos outros pedons, a textura è areia franca e os agregados tipo granulàr, na maioria menores que $0,2 \mathrm{~cm}$.

0 horizonte $A_{12}$ tem $6 \mathrm{~cm}$ de espessura, muito poucas raizes e fragmentos vegetais praticamente ausentes. A parte mineral possui $60 \%$ de areia e $40 \%$ de agregados de cor bruno (IOYR 4/3) com manchas bruno (1OYR 5/3) e bruno acinzentado escuro (10YR 4/2). A textura é franco arenosa e a estrutura granular com unidades de $0,5 \mathrm{a} 2 \mathrm{~cm}$. 
O horizonte $A_{3}$ possui $10 \mathrm{~cm}$ de espessura cor amarelo brunado (10YR 6/6) com manchas bruno amarelado (10YR $5 / 6)$ textura franco arenosa e estrutura fraca em blocos subangulares.

\subsubsection{Ecossistema Alterado}

0 ecossistema alterado inclui quatro āreas des matadas em diferentes e sequenciadas fases de utilização. Em cada uma delas foi caracterizado um pedon, designados como se gue: recēm queimado, cultivado por 1 ano, cultivado por 5 anos, pousio de 3 anos apös 2 anos de cultivo, cujas ciescrições dos perfis correspondentes se encontram no apêndice e a repre sentação esquemätica da parte superior na Figura 4.

As referidas āreas se encontram prōximas, no mā ximo $200 \mathrm{~m}$ uma da outra, a exceção da recém queimada. Esta fi ca adjacente a ārea do ecossistema natural onde foi caracteri zado o pedon bem drenado e estā localizada a aproximadamente Rkm das demais.

Através do estudo dessas āreas se pretende estabelecer a sequéncia de transformações do solo relacionadas à evolução da matéria orgānica até cinco anos de utilização cultivo ou pousio - após o desmatamento.

Nas quatro āreas a vegetação foi eliminada através das práticas da broca, derrubada e queimada, comuns na 


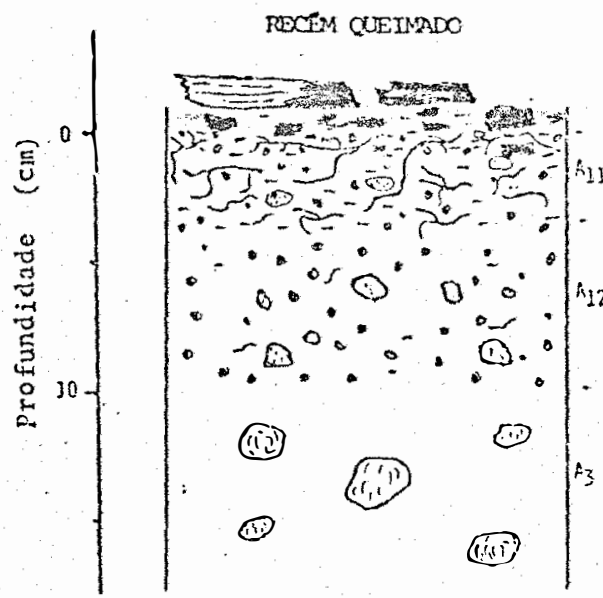

anthino 1 into

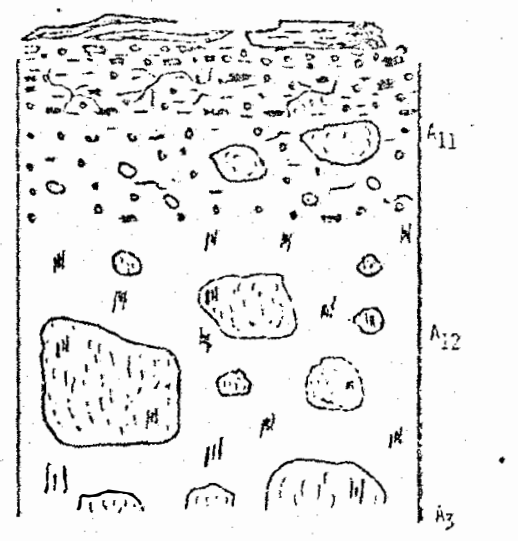

PCUSIO 3 FINGS
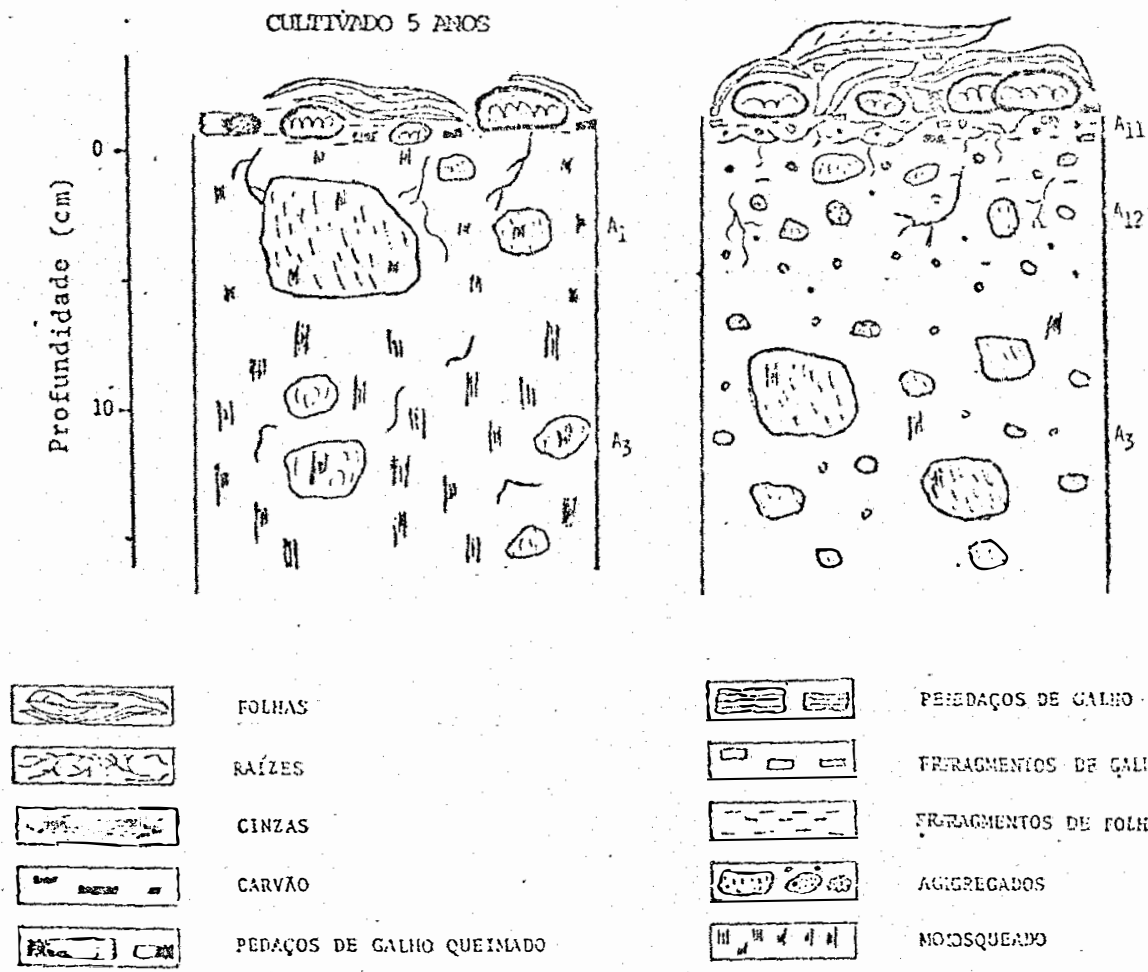

\begin{tabular}{|c|c|}
\hline 00 & EE:EDACSOS DE GILHO \\
\hline $\begin{array}{lll}50 & 0\end{array}$ & 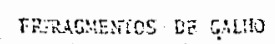 \\
\hline$-\ldots$ & FRDOHENTOS DE rOLHS \\
\hline 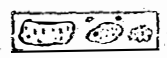 & RGEREGALOS \\
\hline 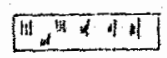 & MO:OSQUE,:YS \\
\hline
\end{tabular}

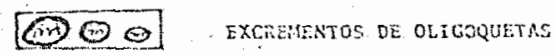

Figura 4. Esquema da parte superior do solo sob ecossistema alterado: recém-queimado, cultivado 1 ano, cultivado 5 anos e pousio de 3 anos (após 2 anos de cultivo). 
região e realizadas nos meses de outubro e novembro.

A broca consiste no corte, com terçado - umá espēcie de facão - das árvores de pequeno porte, visando faci litar a derrubada das árvores maiores. A derrubada é feita com o auxílio do machado, e a queimada realizada após 1 a 2 meses quando a vegetação estiver secado.

Todas as āreas cultivadas tiveram o 10 plantio instalado apōs o desmatramento.

\subsubsection{Area Recém-Queimada}

Estā ārea possui cerca de $50 \times 100 \mathrm{~m}$ e estā lo calizada a $100 \mathrm{~m}$ da ārea do pedon bem drenado. Se encontrá com a vegetação derrubada e queimada. A queimada nela efetuada o correu em intensidade regular.

A superfície está coberta por troncos, pedaços de caules, tombadas e em pé, e raĩzes superficiais, os quais se encontram parcialmente queimados.

A parte superior do horizonte $A_{11}$ estä alterada e constitui uma camada de 0,5 a $2 \mathrm{~cm}$, cujas partes vegetais se compõem de muitos fragmentos vegetais em vias de decomposição, muitas raỉzes não decompostas, estando enriquecida com grande quantidade de cinza e carvão proveniente da queima da. A parte mineral é formada por cerca de $75 \%$ de areia em grãos simples e o restanie de agregados, sendo cerca de 4/5 deles menores que $2 \mathrm{~mm}$. 
0 horizonte $A_{17}$, excluindo a camada jä descrita, possui espessura em torno de $3 \mathrm{~cm}$, cerca de $2 \%$ (em peso) de partes vegetais inciuindo muitas räizes não decompostas,mui tos fragmentos vegetais em decomposição e muito pouco carvão. A parte mineral é formada por $70 \%$ de areia e o restante de agregados tipo granular sendo $2 / 3$ deles menores que $2 \mathrm{~mm}$. A cor dos agregados ē bruno acinzentado $(10$ Y $5 / 2)$ e cinza escuro (10 YR 4/1) e da areia cinza brunado claro (10YR 6/2). A textura è areia.

0 horizonte $A_{12}$ tem $6 \mathrm{~cm}$ de espessura, composição idéntica a do horizonte $A_{1}$, porēm possui textura areia franca e maior quantidade de agregados. A cor dos agregados E bruno acinzentado $(10 Y R 5 / 2)$ e bruno $(10$ YR 5/3), e a da areia bruno amarelado claro (10 YR 6/4).

0 horizonte $A_{3}$ ocupa a profundidade de $10-20$ $\mathrm{cm}$, possui cor amarelo brunada ( 10 YR $\delta / 6)$ com manchas abundantes de tamanho mēdio e contraste distinto, de cor bruno acinzentada (10YR 5/2), textura franco arenosa e estrutura fraca em blocos subangurares.

\subsubsection{Area Cultivada por 1 Ano}

Estā ārea estā localìzada a 70n da ārea do pedon imper feitamente drenado e possui cerca de $80 \times 130 \mathrm{~m}$. Após a queimada a madei ra foi serrada e os caules menores, juntamente coni os galhos maiores, en coivarados em uma faixa de cerca de $5 \mathrm{~m}$ de largura, no centro da ärea,onde foram queimados. Os cautes mais grossos (maior que $80 \mathrm{~cm}$ de circunferēn- 
cia), foram dispostos de modo a ocuparem as ruas do posterior cultivo. Apenas foram destocados os troncos mais grossos.

Três meses após a queimada efetuou-se o plan tio de arroz e daî a 5 meses o plantio de caupi, tendo sido realizadas vārias capinas mánuais.

A superficie se apresenta bastante exposta,coberta pelos troncos situados nas antigas ruas de plantio, por galhos e carvão da vegetação antiga e palha proveniente das culturas e capinas.

Os galhos estão parcialmente queimados e a pa* Iha, que é predominante de gramīneas, em diversos estágios de decomposição, sendo que a parte mais fragmentada desses compo nentes (menor que $1 \mathrm{~cm}$ ) estā misturada a agregados do tipo gra nular, na maioria de tamanho superior a $2 \mathrm{~mm}$. A proporção em peso é de aproximadamente 1 parte de carvão para 25 partes de fragmentos vegetais (galhos e palha) e 270 de solo.

Jā iniciam a brotar, espaçadamente, algumas es pëcies pioneiras que, todavia, não ultrapassam de $15 \mathrm{~cm}$ de altura.

0 horizonte $A_{11}$ tem $6 \mathrm{~cm}$, se apresenta com cer ca de $2 \%$ (em peso) de partes vegetais. Na parte superior (0 $2 \mathrm{~cm})$, bastante influenciada pelas operações de cultivo,pos sui os mesmos componentes encontrados na ārea recēm queimada, sendo que a quantidade de raĩzes è muito menor, a quantidade de carvão ē muito maior e a quantidade de fragmentos vegetais è maior. Na parte inferior $(2-6 \mathrm{~cm})$ possui cerca de $1 \%$ (em peso) de partes vegetais, incluindo raỉzes, fragmentos vegetais, e carvão, todos em pouca quantida- 
de. Neste horizonte a parte mineral é composta de $50 \%$ de are a em grãos simples e $50 \%$ de agregados de àté $3 \mathrm{~cm}$, na maioria menores que $2 \mathrm{~mm}$. A cor dos agregados é bruno (10 YR 4/3) com manchas cinza muito escuro (10 YR 3/l) na parte superior do horizonte e a textura é franco argilo arenosa.

0 horizonte $A_{12}$ possui $9 \mathrm{~cm}$ de espessura, es trutura moderada em blocos subangulares de 1 a $4 \mathrm{~cm}$. A cor é bruno amarelado (10 YR 5/4) com mosqueado comum pequeno e dis tinto, amarelo avermeihado $(7,5 Y R 6 / 6)$ e a textura franco ar gilo arenosa.

0 horizonte $A_{3}$ estā na profundidade de $15-25$ cm, possui cor bruno amarelado claro (10 YR. 6/4) com mosqueado abundante mëdio e distinto, bruno forte $(7,5$ YR $5 / 8)$, textura franco argilo arenosa e estrutura em blocos subangulares com agregados de até $5 \mathrm{~cm}$.

\subsubsection{Area Cultivada por 5 Anos}

Nesta ārea a eliminação da vegetação foi feita de forma idêntica a das āreas jädescritas e a queima dos tron cos e galhos ao invës de concentrada, como na ärea cultivada por 1 ano, foi distribuida em diversos locais.

Possui $12 \times 24 \mathrm{~m}$, todavia é remanescente de uma ārea maior ( $50 \times 50 \mathrm{~m})$ que foi cultivada intensivamente por 4 anos, com dois cultivos anuais, alternando arroz, milho e caupi. Está localizada a cerca de $450 \mathrm{~m}$ das āreas dos pedons 
imperfeitamente e moderadamente drenados e a aproximadamente 2,5 $\mathrm{km}$ da ārea do pedon bem drenado.

Pelo fato da produção ter se tornado insignifi cante no quarto ano, foram feitas modificações no tratamento $\underline{0}$ riginal (cultivo intensivo), sendo introduzidas diversas prāticas de manejo visando a recuperação do solo, reservando-se, todavia, esta àrea, onde, no quinto ano, foi feito um cultivo de milho.

Atualmente, alguns meses após a colheita do mi Iho, a ārea se encontra com vegetação secundāria constituî́da de dois estratos.

010 estrato, corresponde a cerca de $10 \%$ da superfície e é composto de nūcleos esparsos de 3 a 5 embaube ras (Cecropia sp) com 2 a 3 m de altura.

020 estrato possui menos que $1 \mathrm{~m}$ de altura e se compõe de plantas herbāceas das famîlias Compositae e Gramineae, principalmente desta, que cobrem totalmente a superfí cie.

Sobre o solo se encontram fragmentos de galhos parcialmente queimados e carvão, ambos da vegetação primāria, e folhas em decomposição da vegetação atual.

ocorrem depositados sobre a superficie quantidades variáveis de excrementos de oligoquetas que ultrapassam a $0,5 \mathrm{~kg} / \mathrm{m}^{2}$ em alguns locais.

0 horizonte $A$, nesta ārea se subdivide apenas

em $A_{1}$ e $A_{3}$. 
0 horizonte $A_{1}$ tem $7 \mathrm{~cm}$, cor bruno (10 YR 5/3) com manchas bruno amarelado claro (10 YR 6/4), bruno acinzentado (10 YR 5/2) e mosqueado bruno vermelho amarelado ( 5 YR 5/8). A textura é areia franca e a estrutura em blocos subangulares de 1 a $5 \mathrm{~cm}$. A parte vegetal é constituída praticamen te de raĩzes de gramineas, que são finas e muito finas e ocor rem em grande quantidade principalmente no topo do horizonte.

0 horizonte $\mathrm{A}_{3}$ tem $10 \mathrm{~cm}$ de espessura, cor bru no amarelado $(10 \mathrm{YR} 5 / 6)$ com manchas bruno (10 YR 4/3) e mosqueado vermelho amarelado ( 5 YR $5 / 8$ ), textura franco arenosa e estrutura fraca em bloco subangulares. A parte vegetal também é constituīda de raĩzes finas e muito finas, porém em menor quantidade que no horizonte $A_{1}$.

\subsubsection{Area em Pousio de 3 Anos após 2 Anos de Cultivo}

Esta ārea possui $100 \times 100 \mathrm{~m}$ é adjacente a ārea cultivada por 5 anos e teve tratamento igual ao dela até 020 ano de cultivo. A partir do 30 ano, ficou em pousio para sofrer regeneração natural da vegetação, e consequentemente do solo.

Atualmente, 3 anos após o ūltimo cultivo, a ārea possui vegetação secundāria constituīda de quatro estratos.

0 10 estrato é formado pela Cecropia sp (emba beira) que forma nūcleos dispersos nà ārea. 020 estrato é for 
mado principalmente pelas espécies Vismia sp (lacre), Cochlos. permum 0rinocensis stend (periquiteira), Ingāa sp (ingā), Lantana canescens H.B.K. (cidreira brava) e Vitex polygama Cham (Maria preta), sendo estas duas ūitimas, arbustos com hābitos de cipō, portanto de menor porte, porém de maior ocorrência. Es te estrato é sombreado em parte pelo lọ estrato.

030 estrato é formado de arbustos onde dominam as espēcies cidreira brava e Maria preta que, por não dis porem de suporte, se desenvolvem formando tciceiras e, quando secam, dão origem a um cipoal de difícil transposição.

049 estrato é, na maioria, de natureza herbā cea, formado principalmente por gramíneas.

Sobre o solo se encontram peçaços de galinos par cialmente queimados e carvão da vegetação primāria, folhas, ga lhos e fragmentos (de folhas, galhos e frutos) da vegetação a tual.

Existem, depositados, excrementos de oligoque tas, ocorrendo nos locais de menor influēncia do 3 p estrato.são idênticos aos encontrados na parcela cultivada pro 5 anos, po rēm em maior quantidade.

0 horizonte $A$ estä dívidido em $A_{11}, A_{12}$ e $A_{13}$. 0 horizonte $A_{1} l$ varia de 1 a $2 \mathrm{~cm}$ de espessura e possui aproximadamente $2,5 \%$ de partes vegetais, incluindo mais raizes do que fragmentos vegetais os quais estão em proporção equivalente de folhas, galios e carvão. A parte mineral é constituīda de $75 \%$ de areia e $25 \%$ de agregados tipo granular, na maioria maiores que $2 \mathrm{~mm}$. A cor dos agregados è bruno $(10 Y R 5 / 3)$ e bruno acinzentado ( $10 Y R 5 / 2)$ e da areia $\bar{e}$ 
bruno muito claro acinzentado (10 YR 7/3). A textura é areia franca.

0 horizonte $A_{12}$ possui 5 ou $6 \mathrm{~cm}$ de espessura e quantidade muito pequena de partes vegetais, representada praticamente pelas raizes. A parte mineral tem $60 \%$ de areia em grãós simples e $40 \%$ de agregados sendo cerca de $3 / 4$ maiores que $2 \mathrm{~mm}$. Os agregados são bruno acinzentado $(10$ YR $5 / 2)$ e bruno amarelado (10 YR 5/6), tipo granular e em bloco subangular, e a areia bruno (10 YR 5/3). A textura é franco arenosa.

0 horizonte $A_{3}$ tem $13 \mathrm{~cm}$ de espessura, cor bru no amarelado (10 YR 5/6) com manchas bruno acinzentado (10 YR $5 / 2$ ) e mosqueado (pouco e pequeno) bruno forte $(7,5 \mathrm{YR} 5 / 6$ ), textura franco argilo arenosa e estrutura fraca em bloco sub angular.

\subsection{Amostragem}

Em cada uma das āreas estudadas foi feita amos tragem dos residuos vegetais depositados na superficie (1itei ra no caso da floresta), durante o mes de dezembro de 1982.

\subsubsection{Residuos Vegetais sobre o Solo}

A coleta destes elementos foi realizada três diferentes locais de cada ārea, com o auxîlio de um quadro de madeira de $1 \times 1 \mathrm{~m}$. 
Nas āreas de ecossistema natural foram coletadas separadamente, folhas e galhos do lo estrato da liteira. As raizes vivas e os fragmentos vegetais, que associados compõem 020 estrato, foram coletados juntos.

$\mathrm{Na}$ ārea recēm queimada coletou-se os galhos parcialmente queimados separadamente do carvão e das cinzas os quais foram coletados juntos.

Jā nas āreas cultivadas, além dos gâlhos e do carvão, provenientes da vegetação primāria, foram amostrados folhas secas da vegetação atual juntamente com a fitomassa (vi va) sempre que existia, e fragmentos de partes vegetais em de composição tanto de vegetação atual quanto da primäria.

A coleta desses componentes foi realizada em três diferentes locais dentro de cada ārea, com o auxîlio de um quadro de madeira de $1 \times 1 \mathrm{~m}$, à exceção da ārea cultivada por 5 anos onde utilizou-se dois locais. Na ārea em pousio, por existir dominância localizada dos três estratos inferio res da vegetação, cada local foi situado sob a influência de cada um desses estratos.

3.3 .2 . Solo

A amostragem do solo foi feita nos perfis obti dos atravēs de trincheiras, sendo um perfil por ārea, e, tam- 
bēm, na época e nos locais onde foram coletados a liteira e os residuos vegetais sobre o solo.

Em cada ārea, na trincheira, apōs a descrição do perfil, foram coletadas amostras com estrutura deformada e amos tras indeformadas orientadas (em torrões), sempre abrangendo uma' faixa de $10 \mathrm{~cm}$ correspondente a parte central de cada horizonte de limitado, ou, no caso do mesmo ser muito espesso, em duas ou ma is faixas equidistantes.

Após a coleta do material existente sobre o so 10, em cada um dos 2 ou 3 locais de amostragem, dentro de cada ārea, procedeu-se a coleta de amostras do horizonte superficial do solo (horizonte $A$ ).

No horizonte $A_{11}$ a amostragem foi feita retirando-se, com o auxîlio de uma faca, todo o material do horizonte sob $1 \mathrm{~m}^{2}$ delimitado pelo quadro de madeira de $1 \times 1 \mathrm{~m}$.

No horizonte $A_{12}$, ausente na ārea cultivada por 5 anos, e no horizonte $A_{1}$, presente nesta ārea, as amostras foram coletadas retirando-se, tambëm com o auxilio de uma faca, todo o material do horizonte contido no volume abaixo de superficies de $0,01 \mathrm{~m}^{2}$, delimitadas por um quadro de ferro de $10 \times 10 \mathrm{~cm}$. Estas $\mathrm{s} u$ perficies variaram de 3 a 5 dentro de cada ārea de $1 m^{2}$ e a amos tragem foi realizada logo apōs a do horizonte $A_{11}$.

As amostras do horizonte $A_{3}$ foram obtidas do mesmo modo que as do horizonte $A_{12}$, porém, em nūmeros que varia ram de 1 a 3 dentro de cada ārea de $1 \mathrm{~m}^{2}$. Na ārea cultivada por 1 ano não coletou-se o horizonte $A_{3}$ o qual estā representado pela amostra coletada na trincheira. 


\subsection{Preparo das amostras}

3.4.1. Amostras da Liteira e Resĩduos Vegetais

Estas amostras correspondem aos componentes da liteira, obtido nas āreas do ecossistema natural, e do material de origem vegetal existente sobre o solo nas áreas do ecossistema al terado.

Em determinados estratos, devido a intima asso ciação com elementos de outros estratos, as amostras foram coleta das contendo material estranho, havendo necessidade de purifi cā-las.

Assim, as amostras do 20 estrato da liteira constituidas de raizes vivas e fragmentos vegetais em decomposi ção, coletadas nas parcelas de mata, continham agregados de solo. As amostras de folhas secas da vegetação atual da parcela cultiva da por 1 ano possuiam agregados de solo, areia, carvão e fragmentos vegetais em decomposição, enquanto estes, coletados nas parce las cultivadas por 2 e 5 anos, estavam contaminados por carvão, agregados e areia.

Nestas amostras procedeu-se a purificação atravēs de catação manual até separação de pelo menos $95 \%$ da amostra.

Após essa providēncia, cada amostra de material de origem vegetal foi seca em estufa a $609 \mathrm{C}$, depois pesada e acon dicionada.

3.4.2. Amostras de solo 
horizontes do solo, coletadas nos perfis e nas suas proximidades(em äreas de 1 e $0,01 \mathrm{~m}^{2}$ ).

As amostras coletadas em mais de uma ārea

$0,01 \mathrm{~m}^{2}$, dentro de cada $1 \mathrm{~m}^{2}$, foram fundidas de modo a se obter uma amostra composta, correspondente a cada local de amostragem.

De cada amostra de solo foram retiradas duas sub amostras, sendo uma para determinação da umidade atual e a outra pa ra se efetuar as demais anälises.

Em seguida as amostras secaram ao ar e depois fo ram peneiradas em tamiz de $2 \mathrm{~mm}$ para obtenção da TFSA, da fraçăo gros seira do solo e dos fragmentos vegetais maiores que $2 \mathrm{~mm}$. A fração grosseira do solo (maior que $2 \mathrm{~mm}$ ) por ser muito reduzida e as vezes atē inexistente não foi considerada.

\subsection{Anālises}

Foram analisadas as amostras do material de or $\underline{i}$ gem vegetal (liteira e residuos) depositados na superficie e as a mostras deformadas (fração inferior a $2 \mathrm{~mm}$ ) e indeformadas de solo.

As anālises efetuadas permitiram a caracteriza ção da matéria orgânica do solo, do seu complexo de troca e das suas relações massa/volume. Alëm disto procedeu-se a anālise micro morfológica das amostras dos diversos horizontes do solo coletadas. nos perfis.

3.5.1. Matëria Orgânica do Solo

Procedeu-se à determinação do $C$ e $N$ totais dos 
diversos residuos depositados na superficie e do solo, ao fracio namento granulomêtrico da matēria orgânica, ao fracionamento do hūmus.

\subsubsection{Carbiono e Nitrogēnio Totais}

A determinação do C total feita por via seca uti lizando-se o aparelho Carbon Biological oxider e a do $\mathrm{N}$ pelo mé todo Kjedahl.

3.5.1.2. Fracionamento Granulomëtrico

0 fracionamento granulométrico da matéria orgāni ca foi efetuado nas amostras correspondentes ao horizonte A,atra vés de reconstituição a partir das amostras dos subhorizontes, e constou de dispersão com agitação em āgua destilada, aplicação. de ultrasom, separação em tamizes de 0,05 e $0,2 \mathrm{~mm}$ e determina

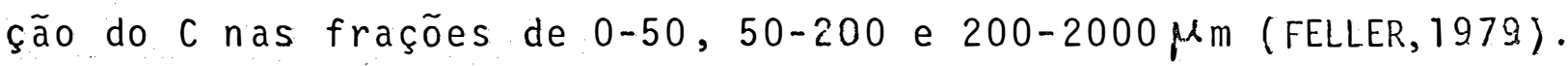
A determinação de C neste caso também foi feita por via seca po rēm utilizando-se o aparelho "Carmograph 12 A".

\subsubsection{Fracionamento do Hümus}

0 fracionamento do hūmus foi feito na fração de

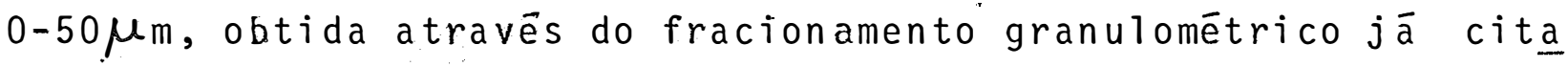
do, que pode ser considerada como detentora da maior parte da ma téria orgânica humificada do solo. Este fracionamento constou da separação das frações hümicas (ācido hūmico ligado, ācido fūivi co livre e ligado, e huminal utilizando-se $\mathrm{H}_{3} \mathrm{PO}_{4} 2 \mathrm{M}, \quad \mathrm{Na}_{4} \mathrm{P}_{2} \mathrm{O}_{7}$ $0,1 \mathrm{M}, \mathrm{NaOH} 0,1 \mathrm{M}$ e centrifugação (DABIN, 197T.). 
$3.5 .2 . \mathrm{pH}$

0 pH foi determinado em āgua e KCl IN utilizan do-se $25 \mathrm{ml}$ de àgua ou da soḷção para log de solo.

3.5.3. Compiexo de Troca Iōnica

Foram determinados os teores de $\mathrm{Ca}, \mathrm{Mg}, \mathrm{Na}, \mathrm{K}$, H e Al trocáveis das amostras de solo dos horizontes A 1 e A 12 - $A_{1}$ e $A_{3}$ no caso da área cultivada por 5 anos - coletas fora do perfil e das amostras dos demais horizontes, coletados nos sete perfis.

A extração do Ca, Mg, H e Al trocāveis foi feita utilizando-se KCl e a do Na e K utilizando-se HCl $0,5 N$.

A dosagem do $\mathrm{Ca}, \mathrm{Mg}, \mathrm{Na}$ e K foi feita no espectofotōmetro de absorção atōmica, a de H+Al por titulação com $\mathrm{NaOH}$ e a de Al por titulação com HCl.

Estas determinações permitiram o cālculo dos va lores de $\mathrm{S}(\mathrm{Ca}+\mathrm{Mg}+\mathrm{Na}+\mathrm{K}$, em emg/lo0g), $\mathrm{T}(\mathrm{S}+\mathrm{H}+\mathrm{Al}$, em emg/lo0g) e $V \%(S / T \times 100)$. 0 valor $T$ neste caso corresponde a capacidade de troca catiónica efetiva.

3.5.4. Granulometria

A granulometria foi avaliada a partir dos dados obtidos no fracionamento granulométrico da matéria orgānica do 
horizonte $A$ onde se considerou as classes 0-2, 2-50, 50-200 e 200-2000 um de diāmetro, e da anālise granulométrica das amostras de diversos horizontes pelo método modificado da pipeta (ORSTOM, sd) procedendo-se a eliminação prévia da matéria orgānica com àgua oxigenada e a dispersã் com hexametafosfato de sōdio e agitação lenta. o grau de floculação foi obtido através da relação entre argila natural e argila total havendo se cons derado argila natural a fração de 0-2 um dispersa em água e argila natural, a dispersa em hexametafosfato de sódio após eliminação da matēria orgãnica..

3.5.5. Relações Massa/Volume

As relações massa/volume foram caracterizadas atra vēs da densidade de partículas, da densidade do solo e do cálculo da porosidade total.

3.5.5.1. Densidade de Partículas

A densidade de particulas foi determinada pelo método do balão volumétrico (EMBRAPA, 1979) utilizando-se álcool metilico para completar o volume.

3.5.5.2. Densidade do Solo

A determinação da densidade do solo foi feita pe 10 método do torrão impermeabilizado com parafina (KIEHL, 1979) 
utilizando-se amostras com estrutura indeformada coletada nos perfis. No horizonte A, de natureza arenosa, onde a variação da densidade é maior utilizou-se o método da escavação (EMBRAPA, 1979). Este método consiste em se preencher, com um volume conhecido de areia, os vazios decorrentes da retirada das amostras contidas no volume abaixo de superficies de,0,01 $\mathrm{m}^{2}$ (ver item 3.3.2.). Na parte superior do horizonte A, corresponden te ao horizonte $\mathrm{A}_{11}$-e $\mathrm{F} / \mathrm{A}_{11}$, no caso do pedon imperfeitamente drenado do ecossistema natural -, onde não foi possivel se utilizar o método da areia, ou do torrão impermeabilizado, em virtude da natureza quase solta da estrutura do horizonte além do sua reduzida espessura, fez-se a simulação do arranjamento do horizonte, no laboratório, utilizando-se provetas de $250 \mathrm{ml}$ para se estimar a densidade do solo.

3.5.6. Micromorfologia

o exame micromorfológico foi feito utilizandose lâminas delgadas obtidas de amostras indeformadas, observadas em uma lupa com aumentos de 9 a 40 vezes. 


\section{RESULTADOS E DISCUSSAOO}

Neste capitulo serao caracterizados e discuti dos os solos sob condição do ecossistema natural e do ecossiste ma alterado. O estudo do solo no ecossistema nas condições natu rais servirá de base para a avaliação das modificações que ocor rem em consequência do desmatamento e da utilização agrícola.

\subsection{Ecossistema Natural}

No ecossistema natural serão estudados a lite ra e os horizontes minerais nas trēs diferentes classes de drenagem no solo já descritas no capitulo 3: Imperfeitamente drena do, Moderadamente drenado e Bem drenado. A drenagem foi o principal fator de diferenciação morfológica detectado no estudo de campo. Outras diferenças foram observadas posteriormente, a partir dos resultados analiticos.

4.1.1. Liteira

A liteira de cada pedon jā foi caracterizada no 
capítulo 3. Neste ítem se discutirā a distribuição de seus com ponentes e respectivos conteúdos de C e $\mathrm{N}$.

\subsubsection{Peso}

A espessura da liteira è variāvel e em geral estā associada ao microrelevo. Devido a existência de peque nas bacias de 1 a 3 metros de diâmetro e flexa variāvel, a e pessura da liteira depende de sua localização no microrelevo. Quanto maior a espessura da liteira, havendo identica distribuição dos componentes, em geral maior o seu peso.

$\mathrm{Na}$ Tabela 1 estão apresentados os pesos úmido e seco da liteira e de seus componentes. Adiante do peso úmido da liteira estão indicados, entre parēntesis, os coeficien tes de variação obtidos entre trēs amostras por pedon pertencente à cada classe de drenagem.

0 peso da liteira do pedon bem drenado è de $23985 \mathrm{~kg} / \mathrm{ha}$, ümido e $21046 \mathrm{~kg} / \mathrm{ha}$, seco. Estes valores são maio res que os da liteira do pedon imperfeitamente drenado (21288 $\mathrm{kg} / \mathrm{ha}$, ümido e $18257 \mathrm{~kg} / \mathrm{ha}$, secol os quais são superiores ao da liteira do pedon moderadamente drenado $(16052 \mathrm{~kg} / \mathrm{ha}$, ümido e $13805 \mathrm{~kg} / \mathrm{ha}$, seco).

Observa-se que os pesos tanto diferem entre os pedons como tambēm entre amostras do mesmo pedon, conforme evidenciam os coeficientes de variação do peso úmido, os quais são de 30,43 e $20 \%$ respectivamente aos pedons imperfeitamente, moderadamente e bem drenados. 


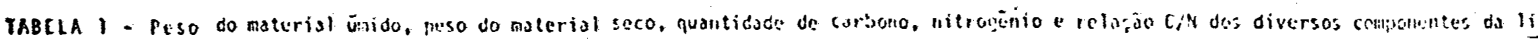
teira no ecossistina natural:

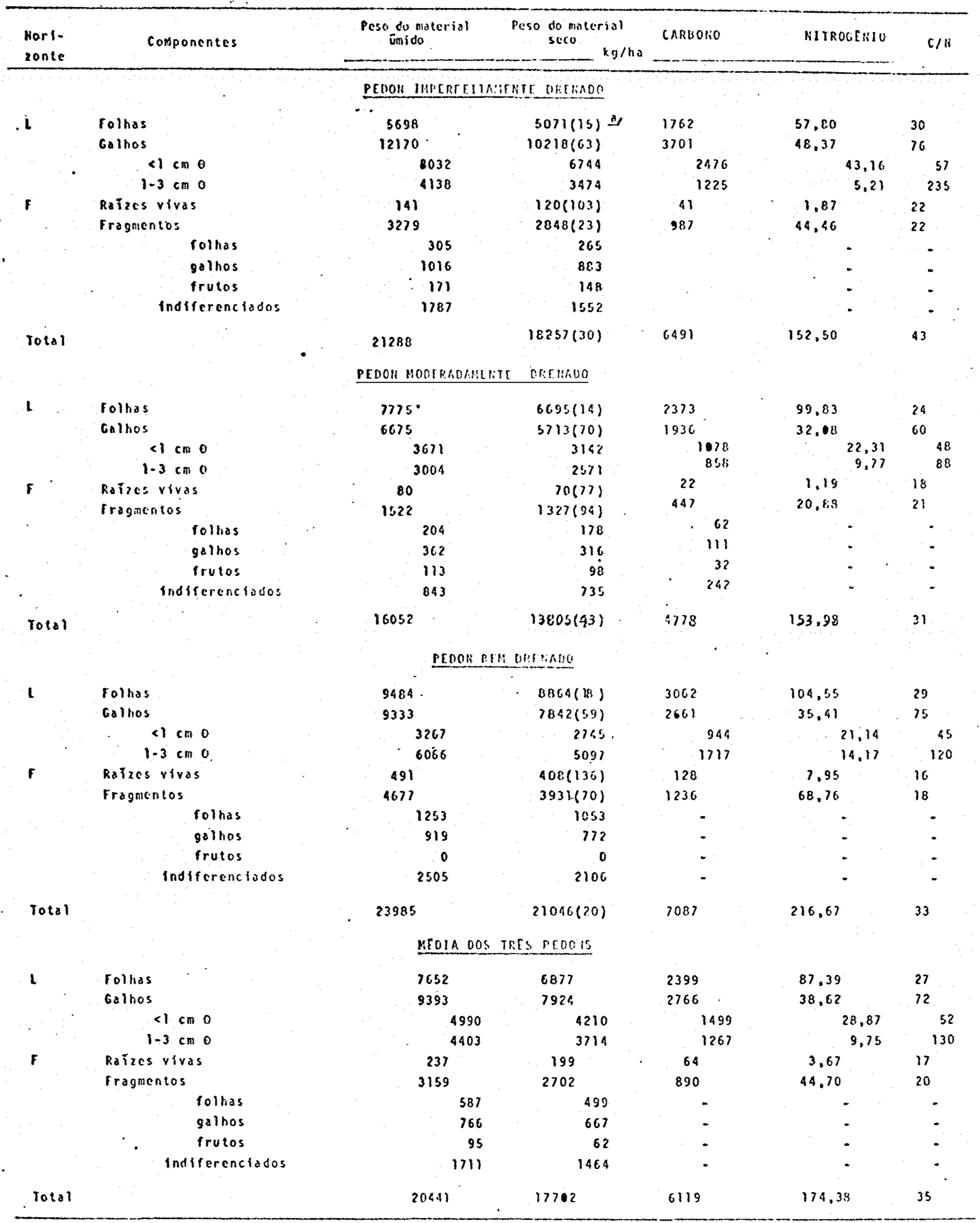

Os números entre parenteses corresponden ao coeficiente de variaçáo entre trés anostras. 
A elevada variação no peso da liteira, observada nas amostras do mesmo pedon, poderia ser explicada pela influência do microrelevo. Já que o peso da liteira depende de sua localização, se estiver situada no interior da bacia será maior que se estiver fora dela. Alēm do mais, serā sempre maior nas bacias de maior flexa e quando localizada mais próxima do centro da bacia.

Como as classes drenagem são determinadas

em maior intensidade pelo microrelevo, os pedons localizados nas cotas mais elevadas apresentam perfis bem drenados. Ao contrārio, os localizados nas cotas mais baixas apresentam perfis moderadamente e imperfeitamente drenados, cujas condições podem ser agravadas pela ocorréncia das microbacias.

Portanto, as microbacias influem, simultanea mente, no peso da liteira e na drenagem acarretando a existência de pedons que pertencem. a mesma classe de drenagem e apre- sentam liteiras com peso diferentes.

A comparação entre o peso médio da liteira dos três pedons está em parte prejudicada pela elevada variação entre as amostras do mesmo pedon. Álém disso, não hā uma relação uniforme entre o peso e a classe de drenagem jā que o pedon moderadamente drenado possui liteira com peso menor que o pedon imperfeitamente drenado.

Os componentes da liteira também, possuem, nos três pedons, pesos com variação relativamente elevada. Dentre esses componentes, as folhas possuem os pesos com menor variação: 14 a 18\%; e as raizes vivas com os de maior: 77 a $136 \%$. 
A Figura 5, contēm a distribuição relativa dos principais componentes da liteira. Atravēs dela verifica-se que os galhos constituem o componente de maior precipitação no peso da liteira. Juntamente com as folhas correspondem, em média, a $84 \%$ do peso da liteira enquanto os fragmentos correspondem à $15 \%$ e, por ūitimo, as raízes vivas à $1 \%$.

Não existe relação uniforme entre 0 peso das folhas e fragmentos com a classe de drenagem. Observa-se que a quantidade de raízes diminui nitidamente nos pedons imperfeitamente e moderadamente drenados. Embora o mesmo aconteça com o peso total dos galhos, verifica-se que a drenagem se correlacio na com o tamanho dos galhos.

Os galhos possuem diāmetro de até $3 \mathrm{~cm}$. Sua subdivisão nas classes de $1-3 \mathrm{~cm}$ e de menos que $1 \mathrm{~cm}$ de diāmetro indica determinada relação com as classes de drenagem. Na Figura 5 observa-se que no pedon imperfeitamente drenado a maior parte $(66 \%)$ dos galhos da liteira possuem diāmetro menor que $1 \mathrm{~cm}$ e a menor parte (34\%) diāmetro de $1-3 \mathrm{~cm}$. Esta distribuição se inverte no pedon bem drenado: a menor parte (35\%) dos galhos tem menos de $1 \mathrm{~cm}$ de diāmetro e a maior parte (65\%) diāmetro de 1-3 cm. A distribuição dos galhos no pedon moderada mente drenado ocupa uma posição intermediāria entre a dos dois outros pedons, possuindo percentuais idénticos entre as duas classes de diāmetro.

A explicação para a relação inversa existente entre o diāmetro dos galhos e a drenagem do solo deve estar ligada ao fato de o impedimento da drenagem influ- 

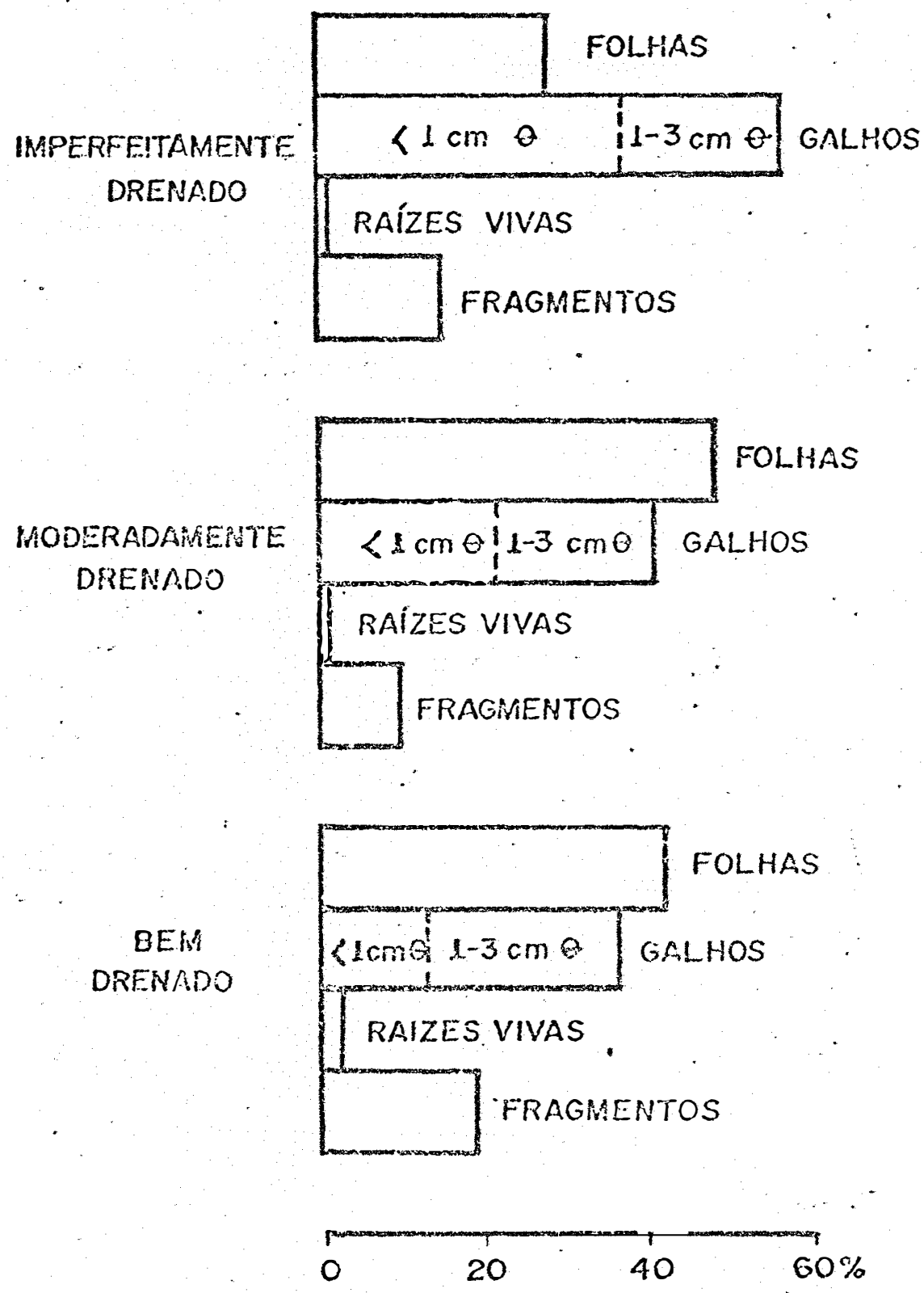

Figura 5. Distribuição relativa dos componentes da liteira nos pedons representativos do ecossistema natu ral: imperfeitamente drenado, moderadamente drenado e bem drenado. 
ir no crescimento das ārvores. Segundo BOULET (1981) uma ārea de floresta, na Guiana Francesa, com drenagem vertical bloque ada apresentou ārvores de maior diāmetro em número três vezes menor que em outra ārea com drenagem vertical livre.

Além dos componentes folhas, galhos e raizzes vivas, os quais se pode considerar componentes primārios, a liteira possui fragmentos em vārios estāgios de decomposição. Estes provem da decomposição dos componentes primārios e, por isso, podem ser chamados de componentes secundārios. Os compo nentes secundārios de maior expressão em peso, e que podem ser reconhecidos, são os fragmentos de folhas, de galhos e de fru tos (Tabela 1 ).

A maior parte dos fragmentos não pode ser sepa rada devido os mesmos terem perdido sua estrutura original.Por esse motivo, foram denominados fragmentos indiferenciados sen do considerados como componentes terciārios da liteira. Eles possuem, na maioria, tamanho inferior a $2 \mathrm{~mm}$ e são oriundos das diversas partes dos vegetais.

A distribuição relativa dos fragmentos da li teira está representada na Figura 6. Verifica-se que a propor ção dos fragmentos indiferenciados ē praticamente a mesma nas três classes de drenagem. Por outro lado, a proporção dos demais fragmentos é semelhante nos pedons das classes imperfeitamente e moderadamente drenados, diferindo da encontrada no pedon da classe bem drenado. Nos dois primeiros pedons cita dos hä relativamente mais fragmentos de galhos que de folhas enquanto no terceiro pedon, o bem drenado, ocorre um percentu彑 

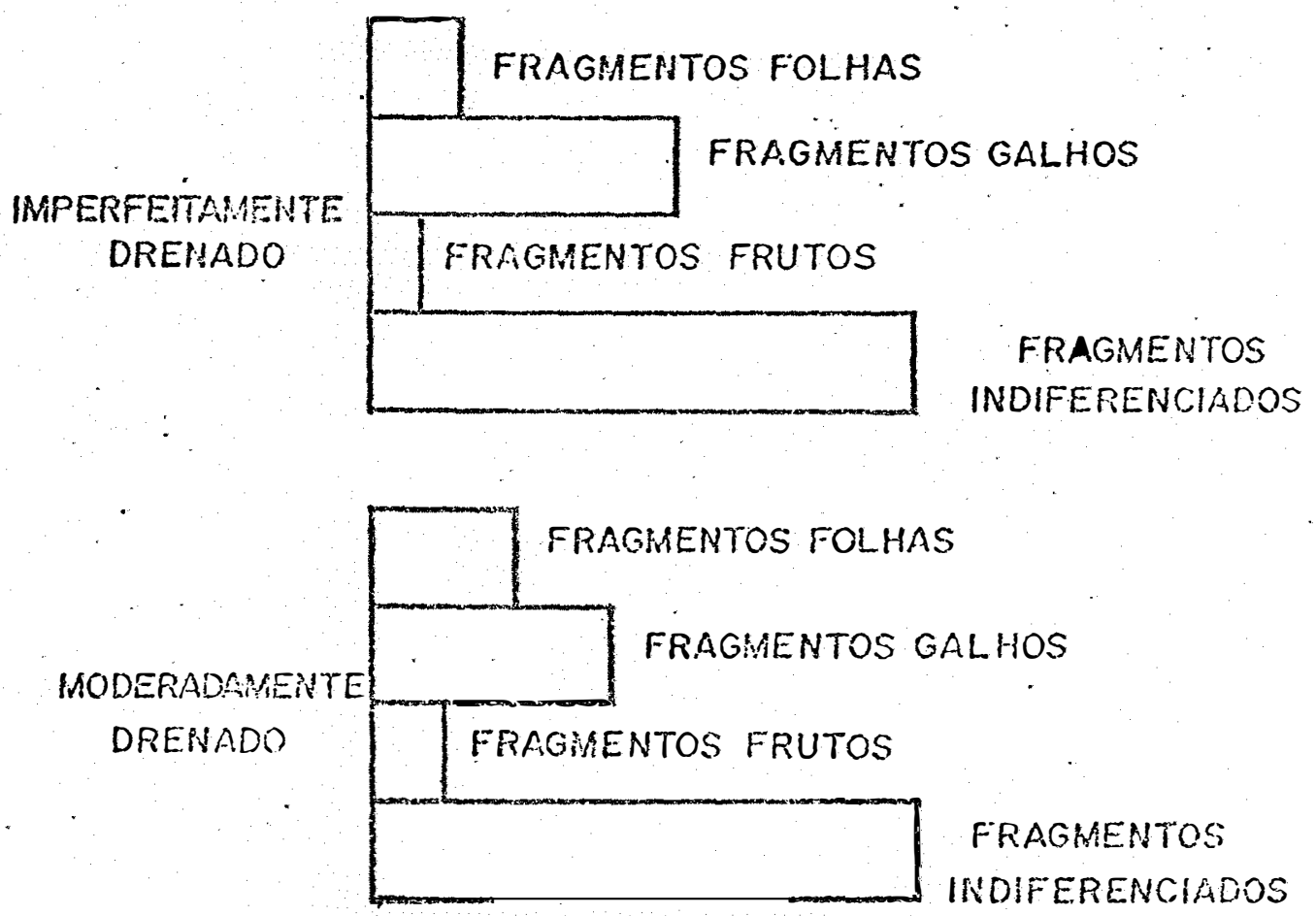

BEM
DRENADO
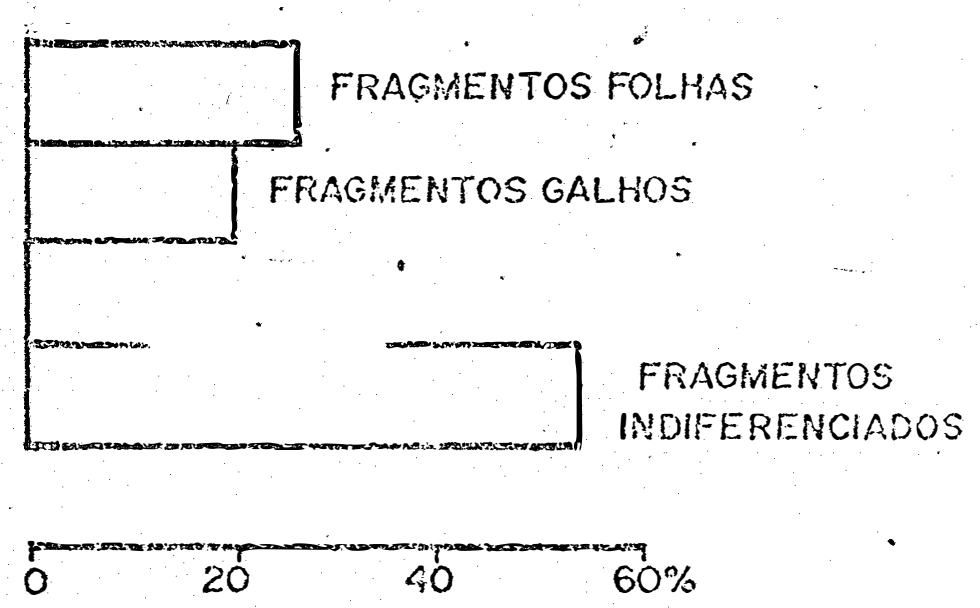

Figura 6. Distribuição relativa dos fragmentos da liteira nos pedons representativos do ecossistema natural: imperfeitamente drenado, moderadamente dre nado e bem drenado. 
al maior de fragmentos de folhas, o que se atribui à maior ocorrência de galhos de diāmetro mais grosso (Tabela 1) e por isso, de maior resistência à decomposição. A ocorrência de fragmentos de frutos é reduzida nos três pedons.

4.1.1.2. Decomposição

A quantidade de fragmentos da liteira, além de depender da quantidade de folhas, galhos e raizes, depende da velocidade de decomposição do material que os constituem.

A velocidade de decomposição, por sua vez, tan to depende do tipo de material que constitui a liteira como das condições do meio, especialmente do clima (FASSEENDER, $1975)$.

Como as condições macroclimāticas são as mesmas nos trēs pedons, comparativamente são mais relevantes as condições de microclima de cada um deles

A Tabela 2, contēm o que foi aqui denominadode indices de desagregação da liteira e de seus componentes. No caso das folhas e dos galhos estes indices foram obtidos divi dindo-se o peso dos seus fragmentos pelo resultado da adição entre esse mesmo peso e o peso do componente que lhe originou. Exemplificando, indica-se como foi feito o cál culo do indice de desagregação das folhas (Id) no pedon imper feitamente drenado. 
$I d=\frac{\text { Peso seco fragmentos folhas }}{\text { Peso seco folhas }+ \text { peso seco fragmentos folhas }}$

$I d=\frac{265}{5071+265} \therefore I d=0,05$

Tabela 2 - Indices de desagregação da liteira e de seus compo nentes, considerando duas fases de decomposição.

\begin{tabular}{|c|c|c|c|c|}
\hline \multirow{2}{*}{$\begin{array}{l}\text { Fase de } \\
\text { Decompo } \\
\text { sição }\end{array}$} & \multirow[b]{2}{*}{ Componente } & \multicolumn{3}{|c|}{ Indice de desagregação a/ } \\
\hline & & $\begin{array}{l}\text { Imperfei- } \\
\text { tamente } \\
\text { Drenado }\end{array}$ & $\begin{array}{l}\text { Modera- } \\
\text { damente } \\
\text { Drenado }\end{array}$ & $\begin{array}{c}\text { Bem } \\
\text { Drenado }\end{array}$ \\
\hline \multirow{3}{*}{$1 \stackrel{a}{-}$} & Folhas & 0,05 & 0,03 & 0,10 \\
\hline & Galhos & 0,08 & 0,05 & 0,09 \\
\hline & Todos & 0,16 & 0,10 & 0,19 \\
\hline $2 \underline{\underline{a}}$ & $\begin{array}{l}\text { Fragmentos } \\
\text { (Indiferenciados) }\end{array}$ & 0,55 & 0,55 & 0,54 \\
\hline
\end{tabular}

a/ explicações sobre a obtenção dos indices no texto.

Os demais indices de desagregação foram calculados de forma anāloga aos das folhas e galhos, sempre relaci onando o componente de nível mais avançado de desagregação com o componente que the originou, portanto, de nivel imediatamen te anterior. Desta forma, o indice de desagregação de todos os componentes, correspondente à primeira fase do processo de de composição, relacionou o totai dos fragmentos-componentes secundārios - com os demais componentes - os primārios. Já o in dice de desagregação correspondente à segunda fase do proces- 
so de decomposição relacionou os fragmentos indiferenciados componentes terciārios - ao total dos fragmentos (Tabela 2).

os indices de desagregação assim obtidos pas sam a expressar o grau de decomposição dos componentes da liteira caso se assuma como verdadeira a existencia de correlação estreita, e sempre positiva, entre a intensidade de decom posição e o indice de desagregação, em todas as fases do processo de decomposição da liteira; ou seja, sob mesmas condi ções, quanto menor o tamanho dos fragmentos, maior a intensidade de sua decomposição. Ou ainda, que a liteira, tende cada vez mais a maior desorganização, isto é, para a māxima entropia, de acordo com o segundo princípio da termódināmica.

Estabelecida esta hipótese deduz-se que do pon to de vista fĩsico, o processo de decomposição se dá inicialmente pela desagregação das folhas, galhos e frutos originando os fragmentos ainda diferenciados que, por sua vez, dão origem aos fragmentos indiferenciados. Logo o indice de desagregação dos componentes primärios, tais como folhas e galhos, reflete o efeito parcial da primeira fase do processo de de composição. Os indices de desagregação referentes a todos os componentes corresponde aos efeitos integrais da primeira fa se, e por fim, o indice relativo aos fragmentos indiferenciados, corresponde os efeitos da segunda fase do processo de de composição. Note-se contudo que, como a liteira é heterogênea e a adição de restos vegetais é praticamente constante, as referidas fases ocorrem simultaneamente.

Com base nas considerações expostas e no exame da Tabela 2, conclui-se que o grau de decomposição das folhas 
e dos galhos segue a seguinte ordem: bem drenado $>$ imperfeita mente drenado > moderadamente drenado. A mesma sequência ocor re com o grau de decomposição dos fragmentos o qual expressa os efeitos acumulados da primeira fase do processo. Portanto, os demais componentes primários são influenciados pela drenagem de forma semelhante à dos galhos e folhas.

Por outro lado, o grau de decomposição dos frag mentos correspondente à segunda fase è praticamente o mesmo nos três pedons evidenciando que, nesta fase, o processo de de composição não sofre influência de drenagem do solo.

Observa-se, tambēm, que nos pedons imperfeitamente e moderadamente drenados os galhos estão sujeitos à decomposição mais intensa que as folhas, ocorrendo o inverso no pedon bem drenado, o que se pode atribuir a sua mais elevada quantidade de galhos de maior diāmetro, mais resistentes à de composição.

0 fato do pedon bem drenado apresentar, na pri meira fase, maior grau de decomposição que os demais pode ser explicado pelas condições mais favoráveis à atividade biolōg ca se considerarmos que nesta fase de decomposição é intensa a participação de pequenos animais, especialmente artóprodos, na fragmentação da liteira.

Por outro lado, o fato do pedon imperfeitamente drenado possuir maior grau de decomposição que o pedon moderadamente drenado, pode ser explicado por, na estação chuvo sa, quando ocorre maior taxa de decomposição (SCHUBART et aliii, 1984), a saturação do solo acarretar a concentração da ativi- 
dade biológica ao nível da liteira e dos primeiros centímetros do solo, aumentando. o grau de decomposição. Essa explicação é reforçada pela existēncia de um horizonte, misturado $F_{/ A}$, no pedon imperfeitamente drenado (ver item 4.1.2.).

\subsubsection{Quantidades de Carbono e Nitrogênio}

As quantidades de $C$ e $N$ da liteira e de seus componentes (Tabela 1) são, em geral, proporcionais aos res pectivos pesos.

Existe no ecossistema natural, em média,17.700 $\mathrm{kg} / \mathrm{ha}$ de liteira, $6.120 \mathrm{~kg} / \mathrm{ha}$ de C e $174 \mathrm{~kg} / \mathrm{ha}$ de $\mathrm{N}$ (Tabela 1).

Considerando-se a variação da drenagem do so10, observa-se que o pedon bem drenado apresenta a liteira de maior peso e com as maiores quantidades de C e N. O pedon moderadamente drenado possui a liteira de menor peso e com a menor quantidade de C. Contudo seu conteūdo em N é intermediá rio entre os outros dois pedons enquanto o da liteira do pedon imperfeitamente drenado è menor.

Logo as quantidades de $N$ não acompanham o peso das liteiras. Embora no pedon moderadamente drenado à liteira seja a de menor peso, a mesma não possui a menor quantidadede N. Por outro lado, a liteira do pedon imperfeitamente drenado contēm a menor quantidade, de $N$ sem ser a de menor peso, conforme é evidenciado pelos respectivos valores de relação C/N. 
As diferenças de valores da relação $\mathrm{C} / \mathrm{N}$ da $\mathrm{li-}$ teira dos pedons imperfeitamente e moderadamente drenados provavelmente tem sua explicação na constituição de seus componentes. De fato, as folhas e os galhos, componentes de maior quantidade na liteira, possuem relação $C / N$ mais baixa no pedon moderadamente drenado que nos demais. Os fragmentos e as raĩzes vivas embora constituam menor porção de $N$ que as folhas, possuem menor relação $C / N$, especialmente no pedon bem drenado.

Assim, as diferenças na quantidade de $\mathrm{N}$ das liteiras se deve principalmente a maior ou menor conteúdo desse elemento encontrado nas folhas e nos galhos.

Teoricamente os conteūdos de $\mathrm{N}$ encontrados nas folhas e nos galhos das liteiras dos diferentes pedons pode ser atribuî́da a duas causas: à constituição original dessas partes vegetais e à evolução diferencial no processo de sua decomposição.

E de se esperar variações no conteūdo de $\mathrm{N}$ e, consequentemente, na relação $C / N$ das folhas e dos galhos de acordo com sua origem e idade (FASSBENDER, 1975). Embora nada se possa afirmar, nesse tocante, com relação às folhas, os galhos apresentam variações substanciais de relação C/N em função da sua espessura.

E plausivel que os galhos de maior espessura te nham majores valores de relação $\mathrm{C} / \mathrm{N}$ em virtude de serem mais velhos e possuirem teores mais elevados de celulose e ligninas, sendo mais baixos os de proteinas. Este fato pode ser cons tatado claramente através da Tabela l. Os galhos da classe de 
1 - $3 \mathrm{~cm}$ de diàmetro apresentam, nas trēs classes de drenagem, valores de relação C/N nitidamente superiores aos da classe com menos de $1 \mathrm{~cm}$ de diāmetro.

observa-se tambēm, que é marcante a influência da relação $C / N$ dos galhos de $1-3 \mathrm{~cm}$ de diämetro no valor da relação C/N calculado para o total dos galhos.

Quanto ao processo de decomposição, deve-se res saltar que as folhas e galhos, por terem sofrido apenas

efeitos do inīcio da primeira fase de decomposição, guardam sua estrutura original e sua constituição não está substancialmente modificada. Por outro lado, as folhas possuindo relação C / N mais baixa constituem a maior fonte de compostos nitrogenados susceptîveis à decomposição.

Desta forma as variações do conteūdo de $\mathrm{N}$ das folhas e galhos da liteira dos pedons imperfeitamente e moderadamente drenados tendem a confirmar os dados sobre decomposi ção já discutidos (item 4.1.1.2.). A liteira do pedon imperfeitamente drenado, esta mais decomposta e, por isso, possui me nor quantidade de $\mathrm{N}$.

Em seguida serão discutidas as principais características físicas, químicas e micromorfológicas dos horizontes minerais.

4.1.2. Horizontes Minerais

Nas Tabelas 3,4 e 5 encontram-se os dados ana lîticos referentes as principais características quĩmicas e na 
Tabela 6 às caracterīsticas físicas dos pedons correspondentes às três principais classes de drenagem do solo que ocor rem no ecossistema natural.

As três classes de drenagem do solo são: imper feitamente drenado, moderadamente drenado e bem drenado e foram assim denominadas com base na morfologia do perfil (ver pêndice, päginas 207 a 216).

ATém da diferença na drenagem, verifica-se a $\underline{e}$ xistência de um horizonte misturado, designado $F / A_{11}$, no pedon imperfeitamente drenado (Figura 3). Este horizonte è proveniente da mistu ra de parte dos framentos do horizonte $F$ da liteira com parte do horizonte $A_{11}$. Sua existência no pedon imperfeitamente drenado indica uma a tividade biológica mais intensa que nos demais pedons, a nivel dos primeiros centimetros do solo.

Devido a sua origem, o horizonte $F / A / l$ do pedon imperfeitamente drenado possui elevado teor de $C$ e $N$, é menos àcido (Tabela 3 ), tem baixa densidade de partículas e é mais poroso (Tabela 6).

Embora haja variação entre os valores que expressam as características dos diferentes pedons, o padrão $\bar{e}$ semelhante nas trés classes de drenagem. Os teores de $\mathrm{C}$ e $N$ descrescem progressivamente com a profundidade e a relação C/ $N$ em geral é mais elevada nos horizontes mais superficiais. 0 pH djminui com a profundidade no horizonte A e aumenta no ho rizonte $B$, ocorrendo o inverso com os valores de $\Delta \mathrm{pH}$ ( Tabe1a 3). A densidade de partículas é, em um mesmo pedon, pouco variāvel e a densidade global tende a aumentar com a profundi 
dade ațe o horizonte $B_{2}$, diminuindo da porosidade total praticamente estâ condicionada à variação da densidade do solo nos horizontes superficiais, e à variação de densidade de particulas nos horizontes mais profundos (Tabela 6 ). 0 estudo micromorfológico tambëm revela aspectos comuns entre os très pedons.

4.1.2.1. Carborio e Nitrogēnio

$\mathrm{Na}$ Tabela 3 constam os conteüdos de C e $\mathrm{N}$ e a rela ção $C / N$ dos três pedons e na Tabela 4 a distribuição do $C$ ate $200 \mathrm{~cm}$ de profundidade.

Observa-se que o pedon imperfeitamente drenado pos sui maior teor de C nos dois primeiros centimetros devido à ocor rência do horizonte $F_{/ A_{T 1}}$. A pertir de seis centímetros de pro fundidade o pedon moderadamente drenado apresenta sempre o maior teor desse elemento. 0 pedon bem drenado possui os mais baixos teores, à excessão da profundidade compreendida entre $0-30 \mathrm{~cm}$ onde são mais elevados que os do pedon imperfeitamente drenado.

Em média o ecossistema natural possui, atē as pro fundidades de $10,50,100$ e $200 \mathrm{~cm}$, respectivamente, 1,83, 4,55, 6,57 e $9,44 \mathrm{~kg} / \mathrm{m}^{2}$ de $\mathrm{C}$.

Embora os ecossistemas naturais em climax astejam, no todo, em equilíbrio dinâmico, onde as perdas devem ser iguais as adições, pode-se esperar a ocorrência de variações internas que se anulam globaimente $j \vec{a}$ que os diversos componentes do ecos sistema são heterogêneos. 
TABLLA 3 - Teores de carbono e nitrogénio totais, relacão C.N, valores de $\mathrm{pH}$ - en ägua e KCl-e $\triangle$ pll dos horizontes mincrais do ecossistema natural.

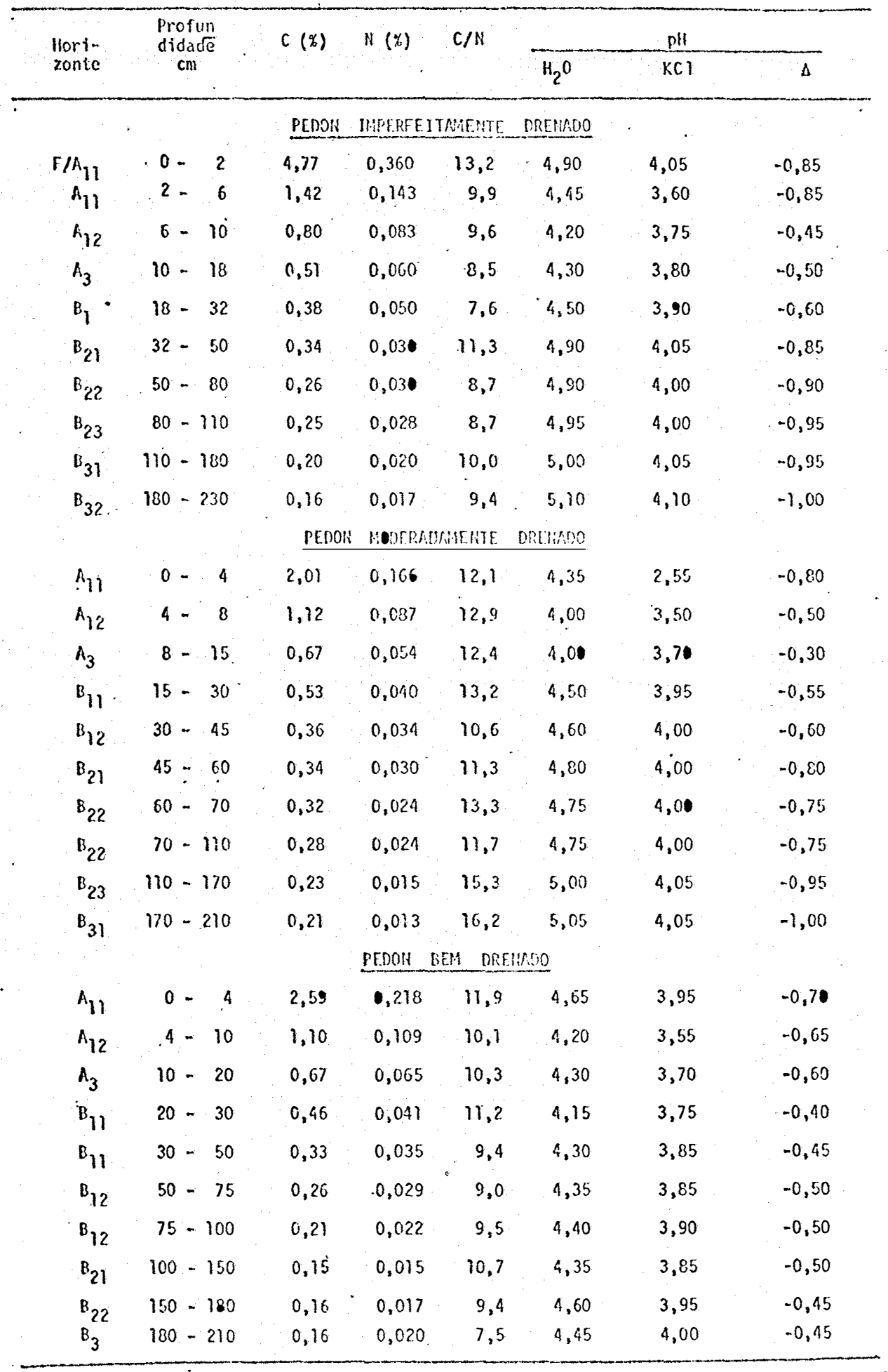


Portanto, a quantidade de C armazenada no solo em determinada parte do ecossistema depende do balanço entre as adi ções e as perdas, e estas ao termo de um ciclo de variação nunca podem ser superiores àquelas.

As adições se dão em consequência da migração, em profundidade, de substāncias hūmicas que se formam ao nível da liteira (MANARINo et alii, 1982) da incorporação de parte dos seus fragmentos, da biomassa microbiana e dos dejetos e cadáve res dos animais.

As perdas ocorrem por erosão, oxidação e lixivia ção do material orgânico (GREENLAND e NYE, 1959) e são influen ciadas pelo clima, textura, drenagem e cobertura vegetal(BUCKMAN e BRADY, 1976), a lém de outros fatores que atuam na atividade' dos organismos tais como pH e disponibilidade de nutrientes( FAS BENDER, 1975 ).

No ecossistema natural em estudo são adicionados anualmente à liteira cerca de 9 t/ha (peso seco) de partes vege tais (EMBRAPA 1981) enquanto a quantidade de C armazenada $\vec{e}$, em média, 6,1 t/ha (peso seco) na liteira (Tabela 1), 66 t/ha até 1 metro e 94 t/ha atē 2 metros de profundidade. Verifica-se, por tanto, que as perdas de $C$, embora inferiores as adições, são mui to intensas, impedindo que haja maior acumulação.

Considerando-se que nesse ecossistema a variação do clima e da cobertura vegetal seja irrelevante e a erosão despresível, restam a textura e a drenagem como fatores responsā veis pela oxidação e lixiviação do C.

os solos arenosos e os bem drenados, em geral 
possuem menores quantidades de $C$ e $N$ que os solos argilosos e os de drenagem deficiente. Jä a relação $C / N$ tende a aumentar nos primeiros em comparação aos üitimos (BUCKMAN e BRADY, 1967).

Atravês da Tabela 4 verifica-se que o pedon modera damente drenado contém uma quantidade de $C$ maior que a dos pe dons bem e imperfeitamente drenados, e estes quantidades idênti cas.

Considerando-se que o processo de armazenamento de C está em equilî́brio dinâmico no ecossistema natural, o que não exclui a ocorréncia de variações internas, tomou-se as profundi dades de $10,50,100$ e $200 \mathrm{~cm}$ como referencial para comparação da distribuição do c conforme consta da Tabela 4.

Tabela 4. Distribuição do carbono ate $200 \mathrm{~cm}$ de profundidade do solo no ecossistema natural.

\begin{tabular}{lcccccc}
\hline \multirow{2}{*}{ Pedon } & \multicolumn{4}{c}{ Quantidade de $c\left(\mathrm{Kg} / \mathrm{m}^{2}\right)$} & & \\
\hline Mat Drenado & $0-10 \mathrm{~cm}$ & $10-50$ & $\mathrm{~cm}$ & $50-100 \mathrm{~cm}$ & $100-200 \mathrm{~cm}$ & Total \\
Moderadamente & 1,81 & 2,52 & 1,96 & 2,80 & 9,09 \\
Bem Drenado & 1,68 & 2,90 & 2,26 & 3,36 & 10,20 \\
\hline Média & 1,99 & 2,75 & 1,83 & 2,47 & 9,04 \\
\hline
\end{tabular}

Verificä-se que de $0-10 \mathrm{~cm}$, embora as diferenças ' não sejam elevadas, o pedon bem drenado possui maior quantidade de $C$ armazenada que os outros dois pedons.

A partir de dez centīmetros, nos intervalos consi 
derados, o pedon moderadamente drenado possui quantidade de C sempre mais elevada que os demais pedons.

Na profundidade de $10-50 \mathrm{~cm} 0$ pedon bem drenado ainda possui quantidade maior que o imperfeitamente drenado, po rém, a partir dẫ os valores são sempre menores.

Portanto, o pedon moderadamente drenado acumula as maiores quantidades de C embora apresente menor quantidade na su perfície $(0-10 \mathrm{~cm})$. O pedon bem drenado acumula mais $\mathrm{C}$ na parte superior $(0-50 \mathrm{~cm})$ que o imperfeitamente drenado enquanto na par te inferior $(50-200 \mathrm{~cm})$ ocorre o inverso.

A maior quantidade de C encontrada na profundidade de $0-10 \mathrm{~cm}$ do pedon bem drenado parece indicar uma maior adição de matēria orgānica. Com efeito verifica-se que a liteira cor respondente a este pedon possui um maior vajor de peso (Tabela.' 1) e maior indice de desagragação na primeira fase do seu proces so de decomposição (Tabela 2). Enquanto isso, o pedon moderadamente drenado tem a liteira de menor peso e o menor indice de de sagregação.

Comparando-se os pedons moderadamente e bem drena dos, as diferenças entre a quantidade de C armazenada podem ser explicadas do seguinte modo: embora as adições sejam maiores no pedon bem drenado as perdas tambēm o são devido as condições de textura e drenagem propícias a oxidação e lixiviação da matéria orgānica, de tal modo que a diferença entre as adições dos do is pedons ē menor que a diferença entre as perdas. Em consequēncia a quantidade de C armazenada é menor no pedon bem drenado. 
No pedon imperfeitamente drenado as adições e as perdas são de magnitude intermediärias entre os outros dois pe dons. A diferença entre as adições do pedon imperfeitamente e do pedon bem drenado $\vec{e}$ semelhante a diferença entre as perdas, då estes pedons possuirem quantidades identicas de C armazenada.

Observa-se então que existe relação direta entre o peso da liteira e a quantidade de C armazenada nos dez primeiros centîmetros. E ainda mais, se considera-se que o peso da liteira determina a magnitude das adições e que o indice de desagregação na primeira fase de decomposição da liteira pode indicar a magnitude das perdas o balanço entre as adições e perdas é perfẹ tamente compatível com as quantidades de C armazenada em cada um dos pedons. Ou seja, as adições e as perdas seguem a ordem de crescente, pedon bem $>$ imperfeitamente $>$ moderadamente drenado. Restaria contudo explicar porque no pedon imperfeitamente drena do as perdas são maiores que no moderadamente drenado.

Ressalte-se contudo que, apesar das diferenças en tre a magnitude das adições e das perdas dos três pedons, a quan tidade de C armazenada não varia muito mais que $10 \%$.

A quantidade de $N$ armazenada no ecossistema natu ral, assim como a de C, varia com a classe de drenagem porēm de forma diferente. 
0 pedon moderadamente drenado possui a maior quantidade de C armazenada e a menor de $N$ o que é evidenciado pelos valroes de relação $\mathrm{C} / \mathrm{N}$, nitidamente mais elevados nos di. versos horizontes em comporação aos outros dois pedons (Tabe$1 a 3)$.

0 pedon bem drenado, que possui a menor quantidade de $C$, armazena mais $N$ que 0 pedon moderadamente drena do, e menos $N$ que o imperfeitamente drenado. Contudo, a relação $C / N$ é semelhante nos pedons imperfeitamente e bem drenados.

A existência de valores de maior relação $C / N$ no pedon moderadamente drenado indica que a oxidação da matéria orgânica é menor que nos demais pedons, o que reforça a ocorrência de maior quantidade de C armazenada.

A diferença entre a quantióade de $N$ armazenada nos pedons bem e imperfeitamente drenados, do mesmo modo que a de $C$, é pequena e se deve igualmente a um balanço final idēntico entre adições e perdas, embora suas intensidades sejam diferentes nesses pedons. Como as quantidades de C e N a mazenadas tambēm são proporcionais, os valores de relação $\mathrm{C} / \mathrm{N}$ são semelhantes.

4.1.2.2. pH e Complexo de Troca Iônica

Os valores de pH em āgua são idênticas nos pedons imperfeitamente e moderadamente drenados e estão em tor- 
no de 4,65 $\pm 0,35$. No pedon bem drenado estão em torno de um valor cerca de 0,3 unidade mais baixo $(4,35 \pm 0,15)$. Essa diferença, porém, praticamente desaparece no pH em KCl, estando os trēs pedons com valores próximos a 3,90 $\pm 0,20$ (Tabela 3 ). Portanto, no complexo de troca iōnica dos três pedons predominam as cargas negativas.

Nos pedons imperfeitamente e moderadamente drenados, ao contrārio do bem drenado, a presença de cargas negativas é mais acentuada na parte superior $(30 \mathrm{~cm})$ sendo sua influência atenuada no horizonte $A_{1}$ onde também é mais elevado o teor de matéria orgānica.

Portanto o complexo de troca iônica é fortemente influenciado nos horizontes superficiais pela maiorià orgânica, especialmente no horizonte que está em contato com a liteira.

Verifica-se, atravēs da. Tabela 5 que os teores de $\mathrm{Ca}, \mathrm{Mg}, \mathrm{Na}$ e $\mathrm{K}$ trocáveis, bem como os valores $\mathrm{S}, \mathrm{T}$ e $\mathrm{V} \%$, são mais elevados nos horizontes superficiais, o que se deve exclusivamente ao maior conteūdo de matéria orgānica.

Por outro lado, nos horizonte onde è muito reduzida a quantiade de matéria orgänica observa-se variações no complexo de troca que são decorrentes da fração mineral do solo.

Considerando todo o perfil, o pedon imperfeitamente drenado possui os maiores valores de $S$. 0 pedon moderada mente drenado possui menor valor s no horizonte $A$ que o pe- 
TABELA 5 - Cātions trocāveis, soma de bàses (S), capacidade de troca de cātions (T) e valor de saturação em bases $(V \%)$ dos horizontes ninerais do ecossistema natural.

\begin{tabular}{|c|c|c|c|c|c|c|c|c|c|}
\hline \multirow{2}{*}{$\begin{array}{l}\text { Hori- } \\
\text { zonte }\end{array}$} & \multirow{2}{*}{\multicolumn{2}{|c|}{$\begin{array}{l}\text { Profundi- } \mathrm{Ca}^{+2} \\
\text { dade }(\mathrm{cm})\end{array}$}} & $\mathrm{Mg}^{+2}$ & $\mathrm{Na}^{+1}$ & $k^{+1}$ & $S$ & $\mathrm{H}^{+1} \quad \mathrm{Al}^{+3}$ & $T$ & \multirow{2}{*}{$V \%$} \\
\hline & & & $\mathrm{emg} / 10$ & 95010 & & $\begin{array}{c}\text { emg } / 100 \mathrm{~g} \\
\text { solo }\end{array}$ & $\begin{array}{c}\text { emg/loog } \\
\text { solo }\end{array}$ & $\begin{array}{l}\text { enig/100g } \\
\text { solo }\end{array}$ & \\
\hline
\end{tabular}

PEDON IMPERFEITAMENTE DRENADO

$\begin{array}{lrrrrrrrrrrr}\mathrm{F}^{\mathrm{A}} \mathrm{A}_{11} & 0- & 2 & 5,47 & 1,22 & 0,19 & 0,38 & 7,26 & 0,58 & 0,10 & 7,94 & 91 \\ \mathrm{~A}_{11} & 2- & 6 & 2,88 & 0,36 & 0,03 & 0,06 & 3,33 & 0,66 & 0,21 & 4,20 & 79 \\ \mathrm{~A}_{12} & 6-10 & 0,29 & 0,13 & 0,02 & 0,04 & 0,48 & 0,83 & 0,40 & 1,71 & 28 \\ \mathrm{~A}_{3} & 10- & 18 & 0,09 & 0,06 & 0,03 & 0,03 & 0,21 & 0,72 & 0,38 & 1,31 & 16 \\ \mathrm{~B}_{1} & 18-32 & 0,12 & 0,04 & 0,02 & 0,02 & 0,20 & 0,74 & 0,37 & 1,31 & 15 \\ \mathrm{~B}_{21} & 32-50 & 0,13 & 0,22 & 0,05 & 0,04 & 0,44 & 0,60 & 0,26 & 1,30 & 34 \\ \mathrm{~B}_{22} & 50-80 & 0,63 & 0,22 & 0,06 & 0,01 & 0,92 & 0,40 & 0,14 & 1,46 & 63 \\ \mathrm{~B}_{23} & 80-110 & 0,33 & 0,12 & 0,06 & 0,02 & 0,53 & 0,64 & 0,32 & 1,49 & 36 \\ \mathrm{~B}_{31} & 110-180 & 0,30 & 0,15 & 0,04 & 0,01 & 0,50 & 0,60 & 0,24 & 1,34 & 37 \\ \mathrm{~B}_{32} & 180-230 & 0,25 & 0,13 & 0,06 & 0,01 & 0,45 & 0,51 & 0,18 & 1,14 & 40\end{array}$

PEDON MODERAMENTE DRENADO

$\begin{array}{llllllllllll}A_{11} & 0- & 4 & 1,23 & 0,57 & 0,13 & 0,19 & 2,12 & 0,77 & 0,25 & 3,14 & 68 \\ A_{12} & 4- & 8 & 0,28 & 0,12 & 0,05 & 0,08 & 0,53 & 0,98 & 0,38 & 1,89 & 28 \\ A_{3} & 8- & 15 & 0,06 & 0,07 & 0,03 & 0,04 & 0,20 & 0,92 & 0,47 & 1,59 & 13 \\ B_{11} & 15-30 & 0,28 & 0,04 & 0,03 & 0,04 & 0,39 & 0,96 & 0,32 & 1,67 & 23 \\ B_{12} & 30- & 45 & 0,14 & 0,03 & 0,03 & 0,02 & 0,22 & 0,88 & 0,32 & 1,42 & 15 \\ B_{21} & 45-60 & 0,15 & 0,07 & 0,04 & 0,02 & 0,28 & 0,84 & 0,32 & 1,44 & 19 \\ B_{22} & 60-70 & 0,06 & 0,09 & 0,03 & 0,02 & 0,20 & 0,82 & 0,34 & 1,36 & 15 \\ B_{22} & 70-110 & 0,04 & 0,07 & 0,04 & 0,02 & 0,17 & 0,84 & 0,41 & 1,42 & 12 \\ B_{23} & 110-170 & 0,01 & 0,06 & 0,03 & 0,04 & 0,14 & 0,66 & 0,28 & 1,08 & 13 \\ B_{31} & 170-210 & 0,01 & 0,05 & 0,06 & 0,02 & 0,14 & 0,56 & 0,26 & 0,96 & 15 \\ B_{32} 210-230 & 0,01 & 0,04 & 0,03 & 0,02 & 0,10 & 0,54 & 0,28 & 0,92 & 11\end{array}$

PEDON BEM DRENADO

$\begin{array}{lrrrrrrrrrrr}A_{11} & 0-4 & 4,94 & 0,74 & 0,08 & 0,21 & 3,97 & 0,52 & 0,10 & 4,59 & 86 \\ A_{12} & 4- & 10 & 0,66 & 0,22 & 0,04 & 0,08 & 1,00 & 0,72 & 0,28 & 2,00 & 50 \\ A_{3} & 10-20 & 0,23 & 0,08 & 0,02 & 0,03 & 0,36 & 0,91 & 0,48 & 1,75 & 21 \\ B_{11} & 20-30 & 0,03 & 0,02 & 0,02 & 0,02 & 0,04 & 1,37 & 0,69 & 2,15 & 4 \\ B_{12} & 30-50 & 0,03 & 0,02 & 0,01 & 0,01 & 0,07 & 1,44 & 0,79 & 2,31 & 3 \\ B_{21} & 50-75 & 0,01 & 0,02 & 0,02 & 0,01 & 0,06 & 1,60 & 0,48 & 2,14 & 3 \\ B_{22} & 75-100 & 0,01 & 0,02 & 0,01 & 0,01 & 0,05 & 1,22 & 0,43 & 1,70 & 3 \\ B_{23} 100-150 & 0,02 & 0,02 & 0,02 & 0,01 & 0,07 & 1,12 & 0,34 & 1,53 & 5 \\ B_{31} 150-180 & 0,01 & 0,01 & 0,02 & 0,01 & 0,05 & 0,88 & 0,34 & 1,27 & 4 \\ B_{32} 180-230 & 0,02 & 0,02 & 0,05 & 0,01 & 0,10 & 0,78 & 0,41 & 1,29 & 8\end{array}$


don bem drenado, ocorrendo o inverso no horizonte B. Quanto aos teores de $H+A l$ trocáveis, são maiores no pedon bem drenado e menores no imperfeitamente drenado (Tabela 5).

Até o horizonte $A_{12}$ os valores médios ponderados de V (em relação a espessura dos horizontes) são de 61,48 e 64 , respectivamente aos pedons imperfeitamente, moderadamente e bem drenados, todos visivelmente correlacionados aos teores de $C$. No horizonte $A_{3}$, onde é menor a influência da matéria orgänica e a fração mineral está muito intemperizada, os valores de $V$ são relativamente semelhantes - 16, 13 e 21 , respectivamente.

Já no horizonte $B$, onde a influencia da matéria orgānica é muito menor, os valores correspondentes à média aritimética entre os subhorizontes são de 38,15 e $4 \%$, respectivamente aos pedons imperfeitamente, moderadamente e bem drenado. Verifica-se portanto, que onde não há influência mar cante da matéria orgānica a saturação de bases é compatível com a classe de drenagem. Assim, quanto mais deficiente a drenagem maior a saturação em bases. Isso é plenamente justificāvel jā que quanto maior a drenagem do perfil maiores são as perdas das bases as quais são substituĩdas pelo $H$ e Al.

Calculando-se a média aritimética de T, entre os subhorizontes do horizonte $B$ constata-se que embora seme1hantes - 1,34, 1,28 e 1,77 emg/100g de solo, respectivamente aos pedons imperfeitamente, moderadamente e bem drenado, dife- 
rem consideravelmente quanto a quantidade de bases e $H+A l$ tro cāveis, acarretando as variações encontradas no valor $V$.

\subsubsection{Textura}

A Tabela 6 apresenta a textura, obtida atravēs do tato, dos diferentes horizontes dos perfis correspondentes a cada um dos pedons.

Os pedons imperfeitamente e moderadamente drenados possuem textura semelhante: franco arenosa nos horizontes $A_{11}$ e $A_{12}$, franco argilosa nos horizontes $A_{3}$ e $B_{1}$, argilo arenosa nos horizontes $B_{21} \in B_{22}$ e argila nos horizonies $B_{23}$, $B_{31}$ e $B_{32}$.

0 pedon bem drenado possui textura mais arenosa que os demais: areia franca no $A_{17}$, franco arenosa nos horizontes $\mathrm{A}_{12}$ e $\mathrm{A}_{3}$, e franco argilo arenosa no restante do per fil.

\subsubsection{Densidade e Porosidade}

Excluindo os horizontes que possuem altos teores de matēria orgānica, observa-se que as variações na dens $\underline{i}$ dade de particulas, densidade do solo e porosidade total dos horizontes do mesmo pedon não são muito acentuadas (Tabela 6).

A densidade de particulas, excluindo os horizon tes que estão em contato com a liteira, varia em torno de $2,79 \pm 0,08 \mathrm{~g} / \mathrm{cm}^{3}$ no pedon bem drenado e $2,82 \pm 0,06 \mathrm{~g} / \mathrm{cm}^{3}$ no 
Tabela 6. Classes de textura e valores de densidade e porosidade do solo no ecos sistema natural.

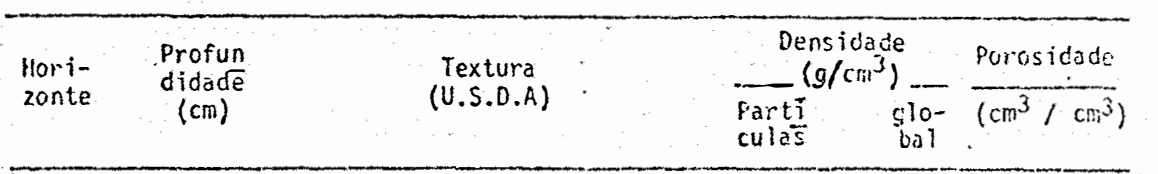

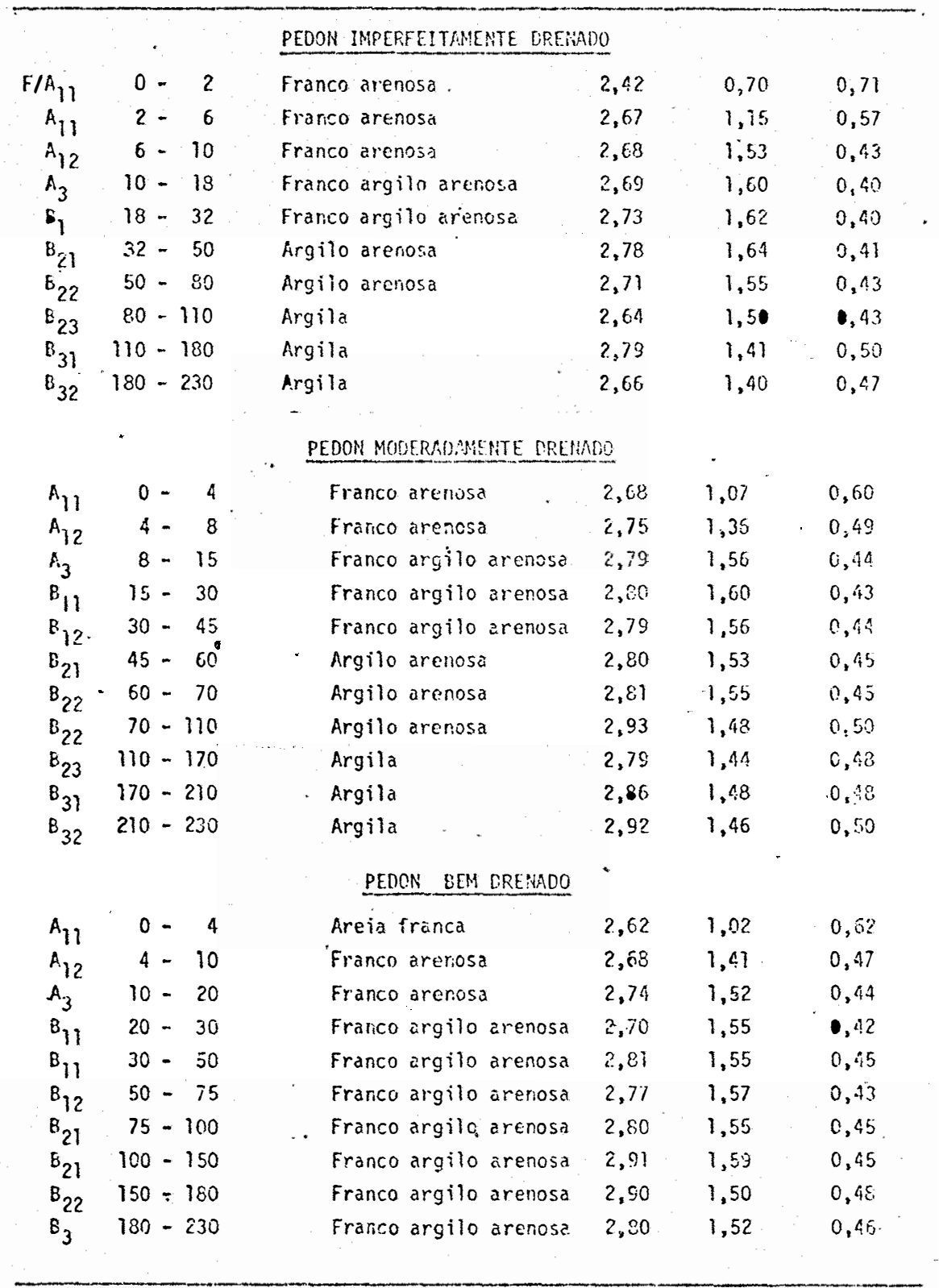


pedon moderadamente drenado. No pedon imperfeitamente drenado ela varia em torno de um valor cerca de $0,1 \mathrm{~g} / \mathrm{cm}^{3}$ menor que os primeiros, ou seja, 2,71 $\pm 0,05 \mathrm{~g} / \mathrm{cm}^{3}$.

Nos trēs pedons a influēncia da matēria orgâni ca sobre a densidade do solo é marcante nos dois primeiros horizontes, não acontecendo o mesmo do terceiro horizonte em di ante (Tabelas 3 e 6 ).

Excluindo o horizonte $A_{1}$, onde é mais elevado o conteūdo de matēria orgānica, os valores de densidade do so. 10: são semelhantes nos três perfis e estão em torno de 1,53 $\pm 0,06 \mathrm{~g} / \mathrm{cm}^{3}$.

A porosidade total $\bar{e}$ mais alta nos horizontes que possuem elevado teor de matēria orgānica devido à influēn cia da densidade global. Todavia, nos demais horizontes há in fluência maior da derisidade de particulas acarretando varia ções entre os pedons.

Comparando-se a mēdia ponderada em função da es pessura, embora com variações entre os horizontes $A_{11}$ e $A_{12}$, o horizonte $A_{1}$ possui valores de porosidade muito semelhantes nas trēs classes de drenagem.

Excluindo o horizonte $A_{1}$, a porosidade total varia ao redor de $0,45 \pm 0,02 \mathrm{~cm}^{3} / \mathrm{cm}^{3}$ no perfil bem drenado e 0,46 $\pm 0,03 \mathrm{~cm}^{3} / \mathrm{cm}^{3}$ no perfil moderadamente drenado. No perfil im perfeitamente drenado os valores são menores e estão em torno de $0,44 \pm 0,04 \mathrm{~cm}^{3} / \mathrm{cm}^{3}$.

Verifica-se, portanto que, excluindo a influẹn cia da matéria orgânica, os perfis possuem variações na densi 
dade de particulas que por sua vez influem na porosidade total. o perfil imperfeitamente drenado possui fração mineral de menor densidade que os demais acarretando menor porosidade já que a densidade do solo é pouco variável quando não hā elevado conteú do de matēria orgānica.

As diferenças entre os valores de densidade de partículas dos pedons bem e moderadamente drenados são pequenas e justificam a menor diferença de porosidade entre esses pedons a partir dos horizontes menos influenciados pela matéria orgâni ca. Contudo, o fato do pedon bem drenado apresentar valores me nores pode ser atribuído ao seu menor conteúdo de argila.

Não se observa relação estreita entre a porosidade total e a classe de drenagem dos pedons, o que é justificâa vel jā que os valores de porosidade não são muito diferentes e hā variação na granulometria. Contudo a relação entre a classe de drenagem e a microporosidade deve ser estreita. Nos pedon im perfeitamente e moderadamente drenados o horizonte $B_{21}$ apresenta-se fortemente adensado onde o plasma é interrompido por uma quantidade reduzida de vazios do tipo fissural que ocorrem rela tivamente isolados, o que foi constatado através da anālise mi cromorfológica.

\subsubsection{Micromorfologia}

A seguir são apresentadas as principais diferen ças bem como as caracteristicas mais comuns entre os três pedons do ecossistema natural. 
0 pedon imperfeitamente drenado possui no horizon te $A_{1}$ considerāvel quantidade de macroporos de aproximadamente 1 $\mathrm{mm}$ de diāmetro associados a uma matriz com abundante quantidade' de quartzo, um plasma bruno escuro microagregado, irregularmente distribuido e numerosa quantidade de raĩzes e resîduos orgänicos (Figura 7). No horizonte $A_{3} 0$ plasma envolve grande parte do es queleto, é bem distribuĩdo e a macroporosidade é mais reduzida que no horizonte $A_{1}$ (Figura 8). Jā no horizonte $B$ o plasma é con tínuo e em maior quantidade, a macroporosidade é muito reduzida, constituida principalmente de vazios do tipo fissural, os quais na parte superior deste horizonte estão associados à argilans de cor amarelo alaranjado. (Figura 9).

0 pedon moderadamente drenado possui no horizonte A uma distribuição heterogēnea do plasma que apresenta-se microa gragado e de cor bruno muito escuro. Observa-se ainda neste hor zonte numerosas raizes e elevada porosidade intersticial entre os grãos de quartzo e os microagregados (Figura 10). 0 horizonte $B$ apresenta-se pouco uniforme; na parte superior $\left(B_{1}\right)$ o plasma é formado por pequenos agregados de forma arredondada, delimitados por vazios policoncavos (Figura 11 ). A parte central $\left(B_{2}\right)$ apre senta vazios em quantidade reduzida, embora predominem os vazios policoncavos e não os do tipo fissural, preenchidos em parte por argilans associados a pequenas manchas avermelhadas com limites difusos e possui distribuição irregular do esqueleto (Figura 12) $\mathrm{Na}$ parte inferior $\left(B_{23}\right.$ e $\left.B_{3}\right)$ ocorrem concentrações de plasma (Figura 13) e de nōdulos férricos que se apresentam com limites difusos. Estes mōdulos contem grãos de quartzo parcialmente imer sos no plasma do fundo matricial (Figura 14). 


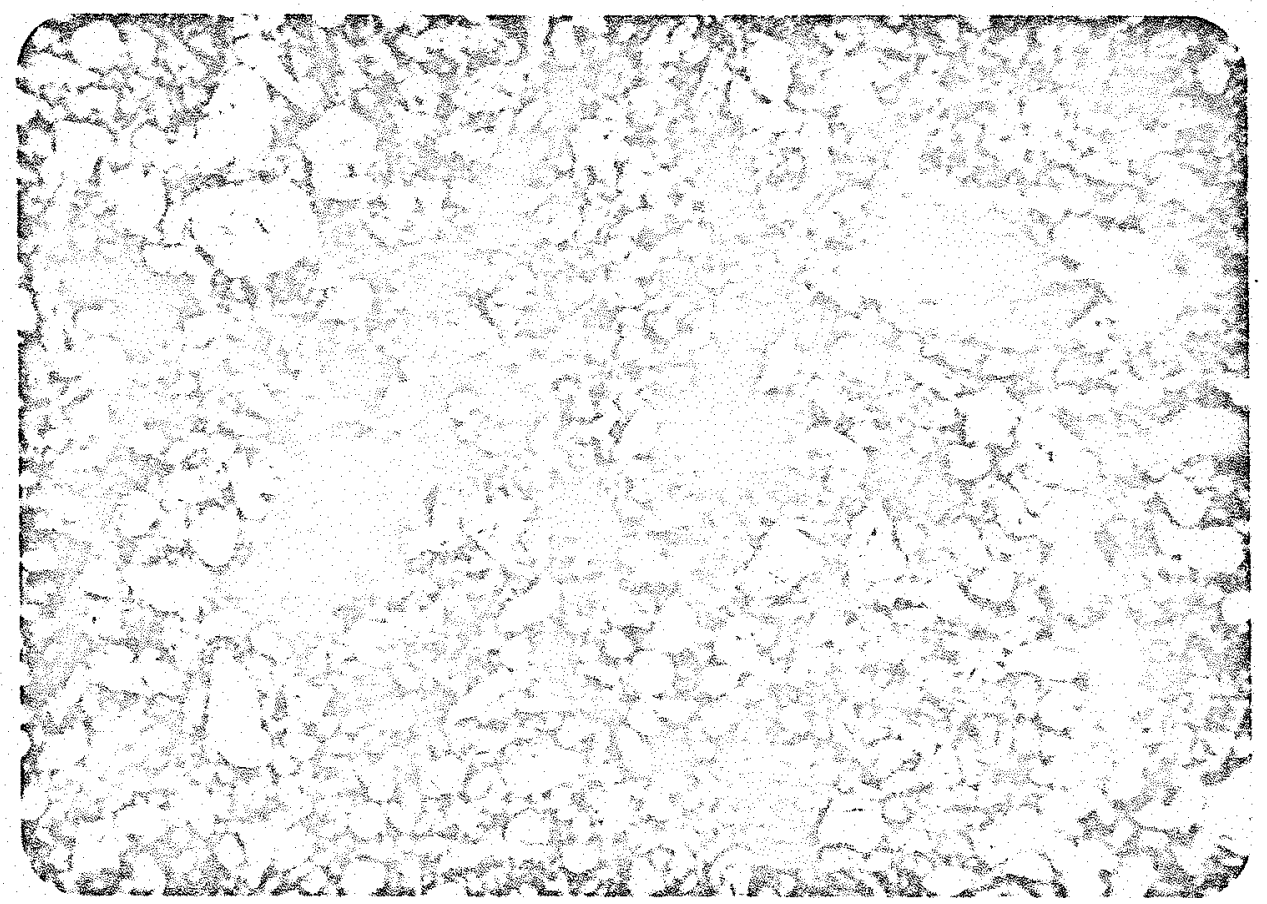

Figura 7 - Fotomicrografia $(12 X)$ relativa ao horizonte $A 12(6-10 \mathrm{~cm})$ do Pecon Imperfeitamente Drenado do Ecossistema Natural: Distribui ção enaulic com um esqueleto constituĩdo principalmente de quartzo, um plasma bruno escuro com distribuição irregular bastante microagregado e a presença de raízes e resíduos vegetais.

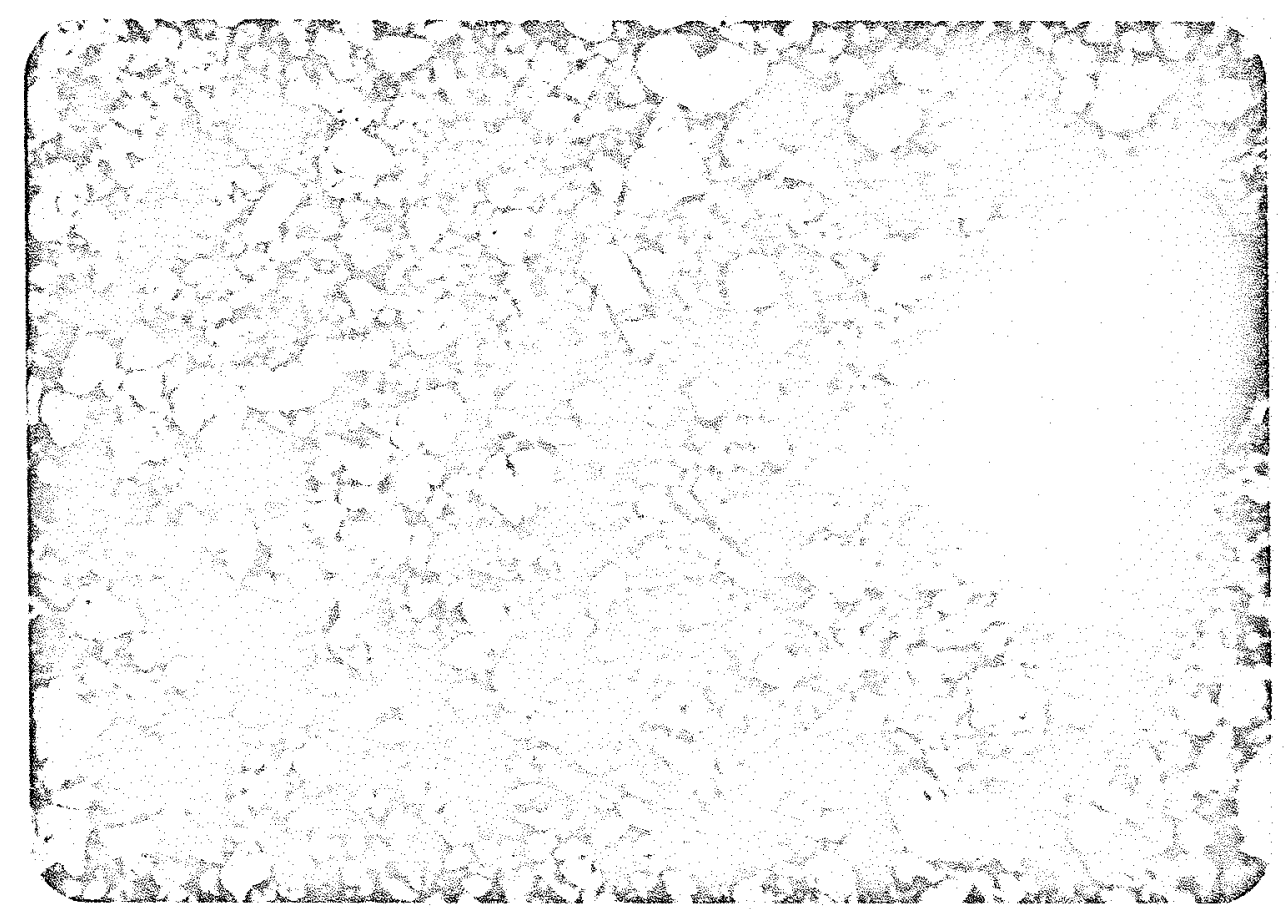

Figura 8 - Fotomicrografia (12X) relativa ao horizonte $A_{3}(10-18 \mathrm{~cm})$ do Pedon Imperfeitamente Drenado do Ecossistema Natural: Plasma regularmente distribuido, envolvendo grande parte do esqueleto, exibindo uma macroporosidade relativamente pouco desenvolvida. À direita aparece un nōdulo férrico. 


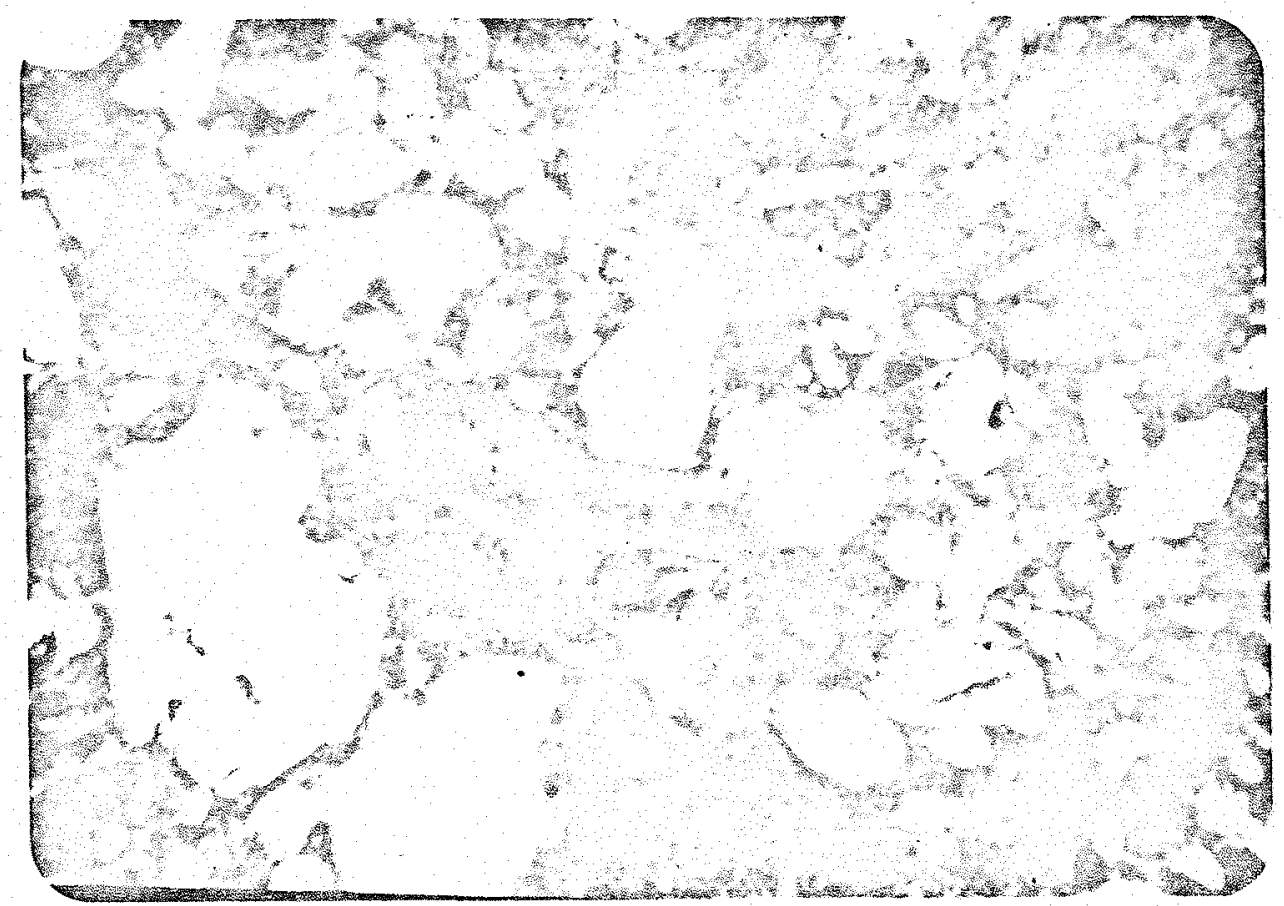

Figura 9 - Fotomicrografia (53X) relativa ao horizonte $B_{27}(32-50 \mathrm{~cm})$ do $\mathrm{Pe}$ don Imperfeitamente Drenado do Ecossistema Natural: Distribui= ção porfiric onde o plasma se apresenta contīnuo, a macroporosi dade muito reduzida e os grãos de quartzo agrupados os quais con tēm grande quantidade de óxido de ferro encrustado. Vazios dó tipo fissural são limitados por argilans amarelo alaranjado.

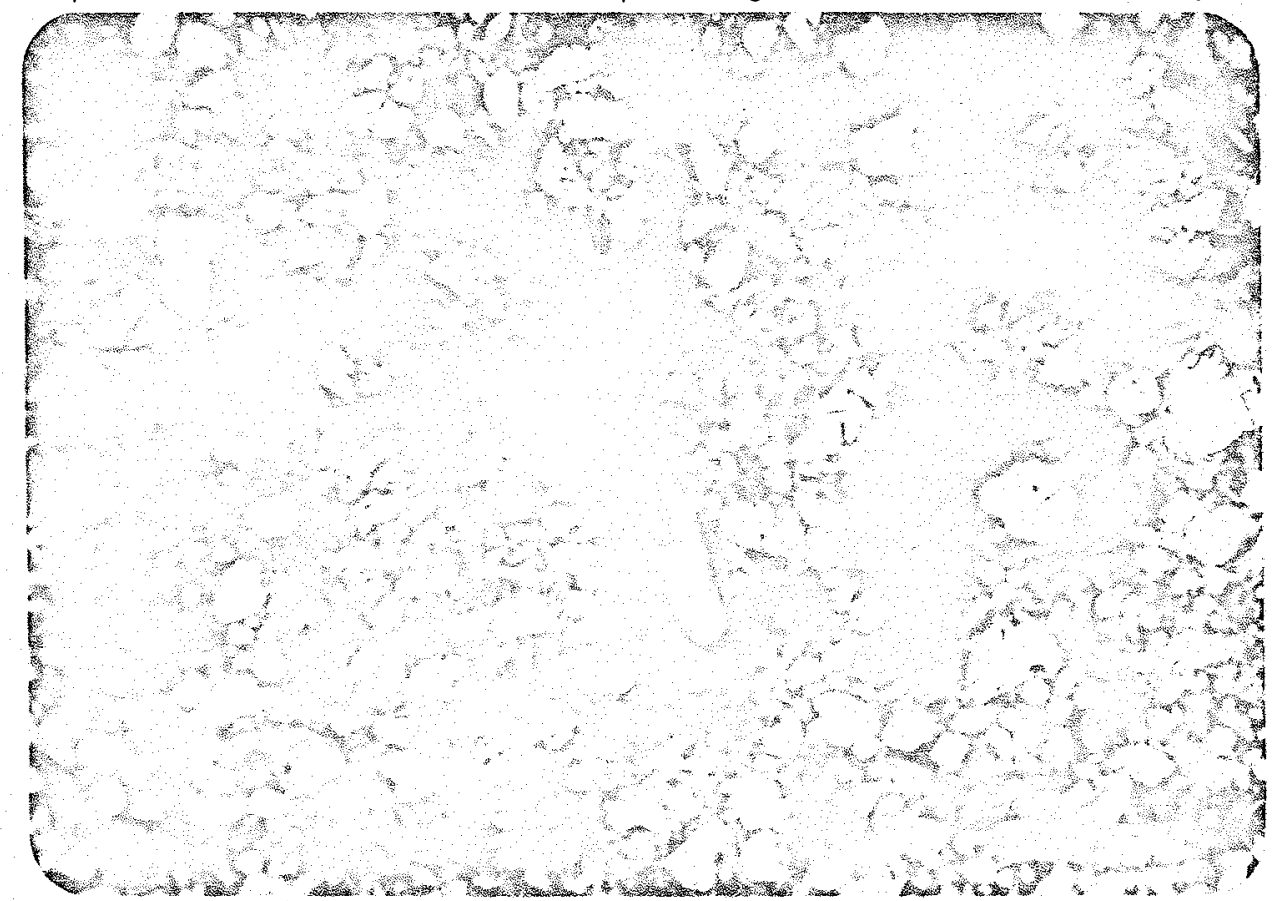

Figura 10 - Fotomicrografia (12X) relativa ao horizonte $A_{12}(4-8 \mathrm{~cm})$ do Pedon Moderadamente Drenado do Ecossistema Natural: Distribui ção heterogénea do plasma de cor bruno muito escuro, muito microagregado e com um padrão enaulic. Numerosas raízes e eleva da porosidade intersticial entre os grãos do esqueleto e os mi croagregados. 


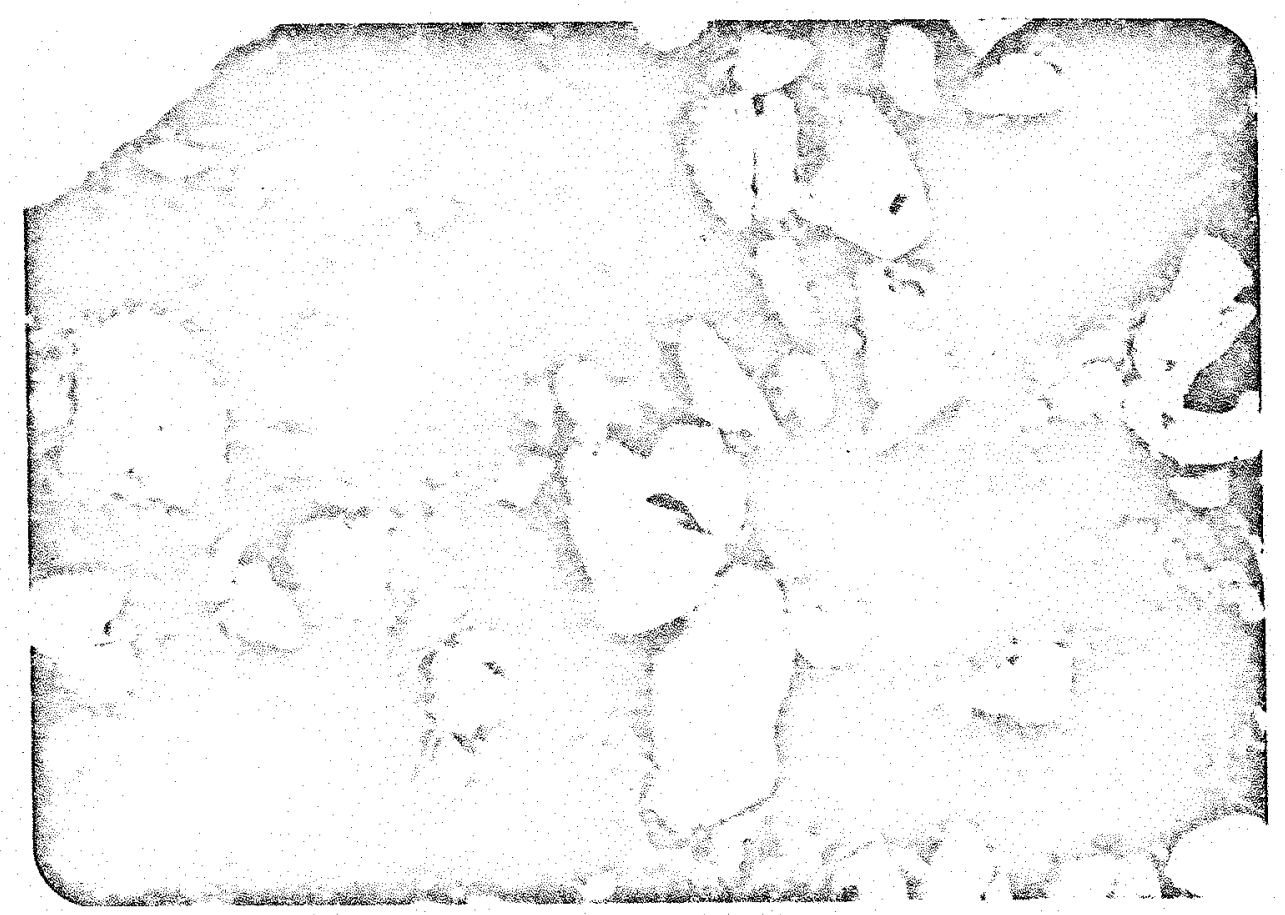

Figura 11 - Fotomicrografia (53X) relativa ao horizonte $B 1](15-30 \mathrm{~cm})$ do Pedon Moderadamente Drenado do Ecossistema Natural: Presença de pequenos agregados milimétricos de forma relativamente arredondada delimitados por vazios policóncavos de aproximadamen te $1 \mathrm{~mm}$ de diämetro. Note-se tambēm a distribuição agrupāa da do esqueleto e a forte incrustação de oxido de Fe nos grãos de nliart>n.

Figura 12 - Fotomicrografia (33X) relativa ao horizonie $B_{22}(60-70 \mathrm{~cm})$ do Ecossistema Natural: Em um padrão de distribuição porfiric dis tingue-se, à direita, setores de plasmia muito claro com macroporosidade muito reduzida devido o preenchimento dos vazios por cutans argilosos, associados a pequenas manchas avermelhadas e violäceas com limites difusos; a esquerda a ocorréncia de vazios policoncavos, tambëm com manchas avermelhadas com limites difusos, e grãos de quartzo agrupados. 


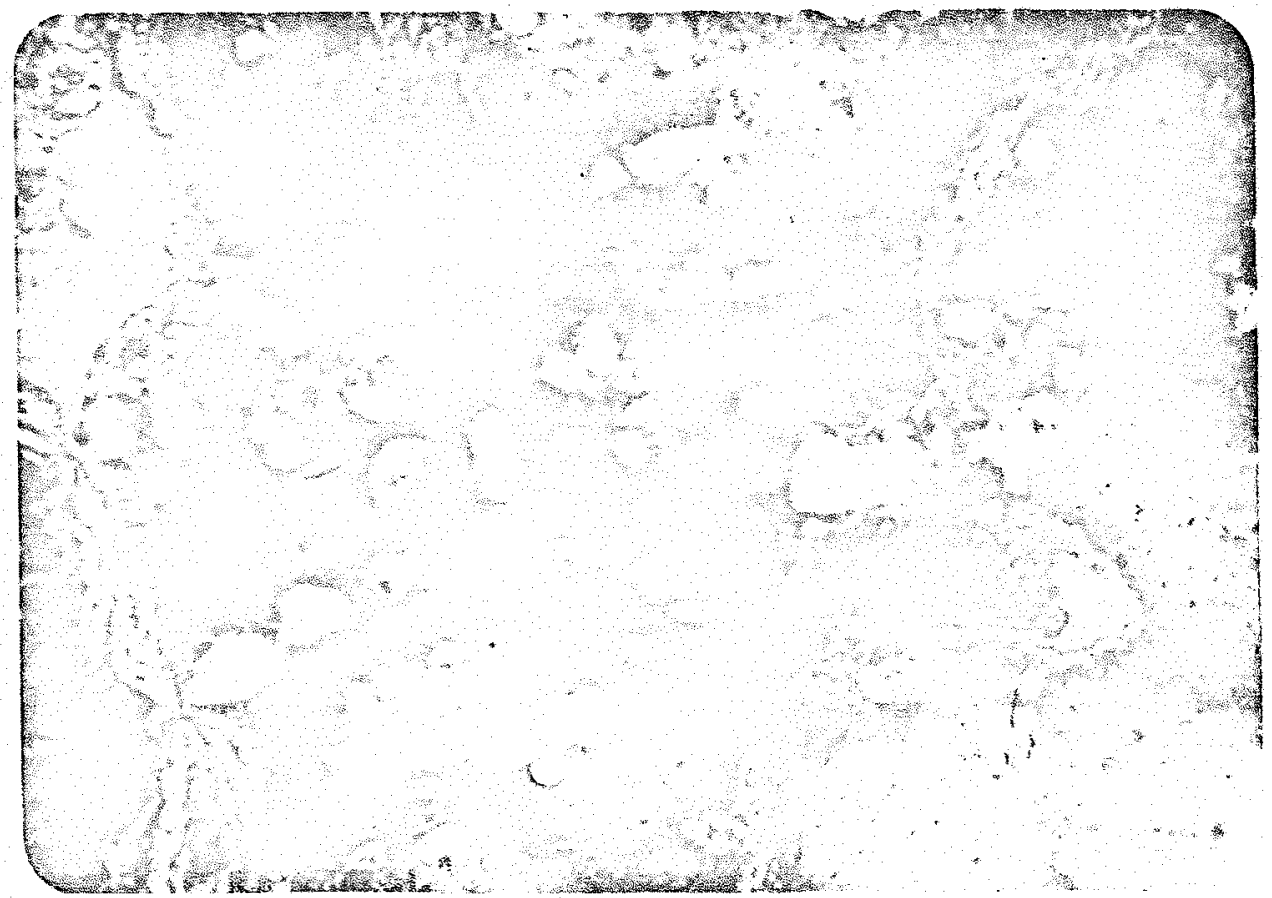

Figura 13 - Fotomicrografia (24X) relativa ao horizonte $B_{23}(110-170 \mathrm{~cm})$ do Pedon Moderadamente Drenado do Ecoss is tema Natural: Aspectos da degradação de um material endurecido muito rico em plasma de coloração bruno, muito associado aos vazios.

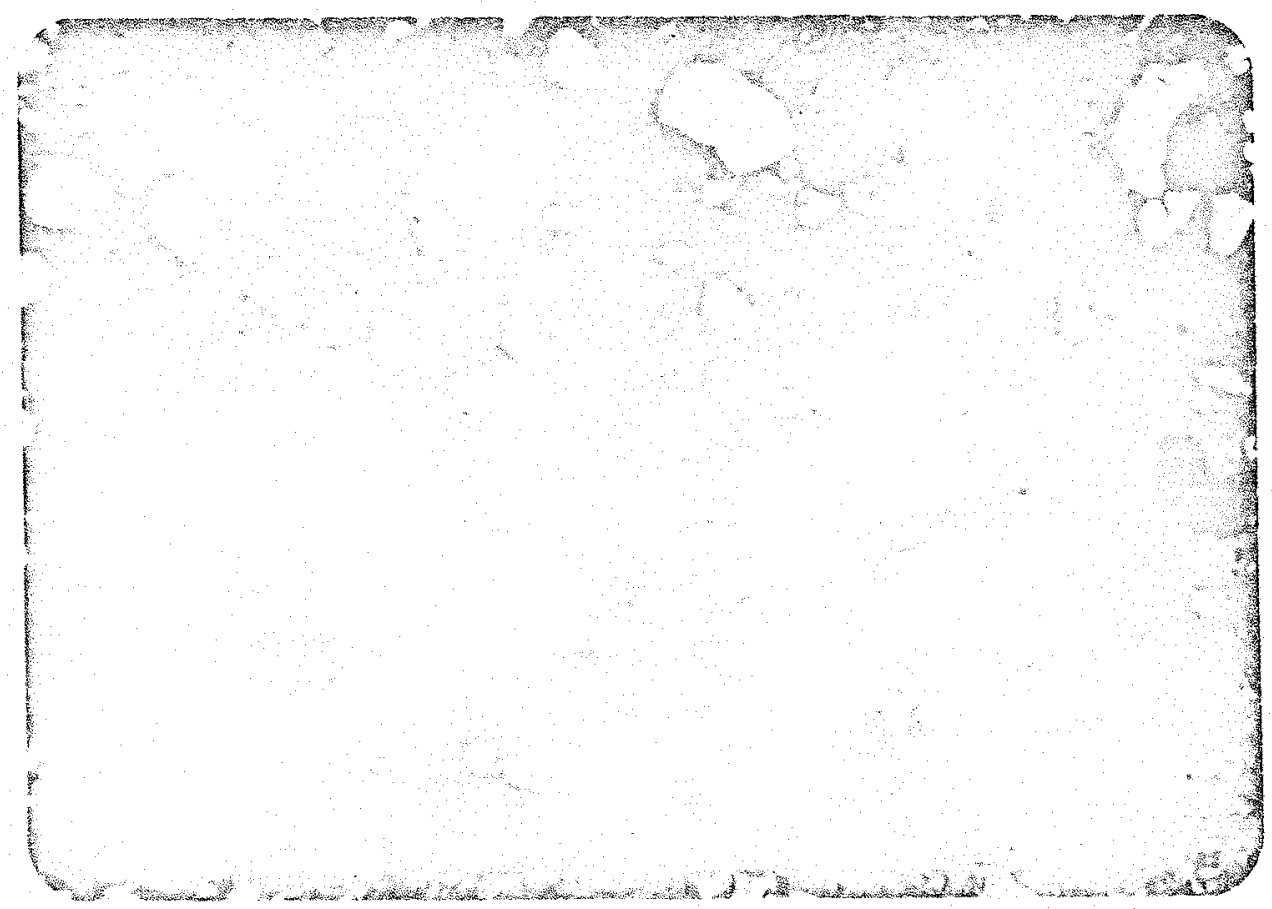

Figura 14 - Fotomicrografia $(13 X)$ relativa ao horizonte $B_{32}(210-230 \mathrm{~cm})$ do Pedon Moderadamente Drenado do Ecossistema Natural: Degradação de nödulos férricos que parecem fundir-se à matriz constituīda principalmente de um plasma bruno amarelo que envolve os grãos de quartzo em um padrão tipicamente porfiric. 
0 horizonte A do pedon bem drenado possui parte do plasma concentrado na forma de enchimentos de pedutubos com orientação dominantemente vertical, contendo grãos de esquele to. A parte grosseira do esqueleto por vezes forma agrupamen tos frouxos tendendo a um padrão de distribuição monic, com porosidade intersticial entre grãos de quartzo elevada, conten do pequenos agregados de plasma bruno e partículas orgānicas (Figura 15). No horizonte B o plasma é bruno, denso, continuo, distribuido de forma relativamente homogénea envolvendo os grãos de esqueleto. A macroporosidade é reduzida e ocorrem pequenos depósitos argilosos com limites difusos em torno dos vazios (Figura 16).

Nos três pedons o padrão de distribuição relati va entre as particulas fina e grosseira (STOOPS e JONGERIUS, 1975) é enautic (1) no horizonte $A_{1}$ (Figuras 7 e 10) enaulic/porfiric no horizonte $A_{3}$ (Figuras 8 e 15) e porfiric no horizonte $B$ (Figuras 9, 14 e 16). O esqueleto é formado principalmente por grãos de quartzo juntamente com pequenas quantidades de magnetita, zi $\underline{r}$ conita, hornblenda (Figura 16) e staurolita. Os grãos de quartzo apresentam-se muito arredondados, com muitas cavernas de corrosão e fissuras preenchidas por öxidos de Fe (Figuras 9 e 11). Frequentemente aparecem grãos de quartzo que, reunidos,

(1) Para melhor compreensão do leitor menos familiarizado com a terminologia utilizada em micromorfologia oferecemos no Apêndice (página 206) uma relação dos significados dos termos aqui empregados. 


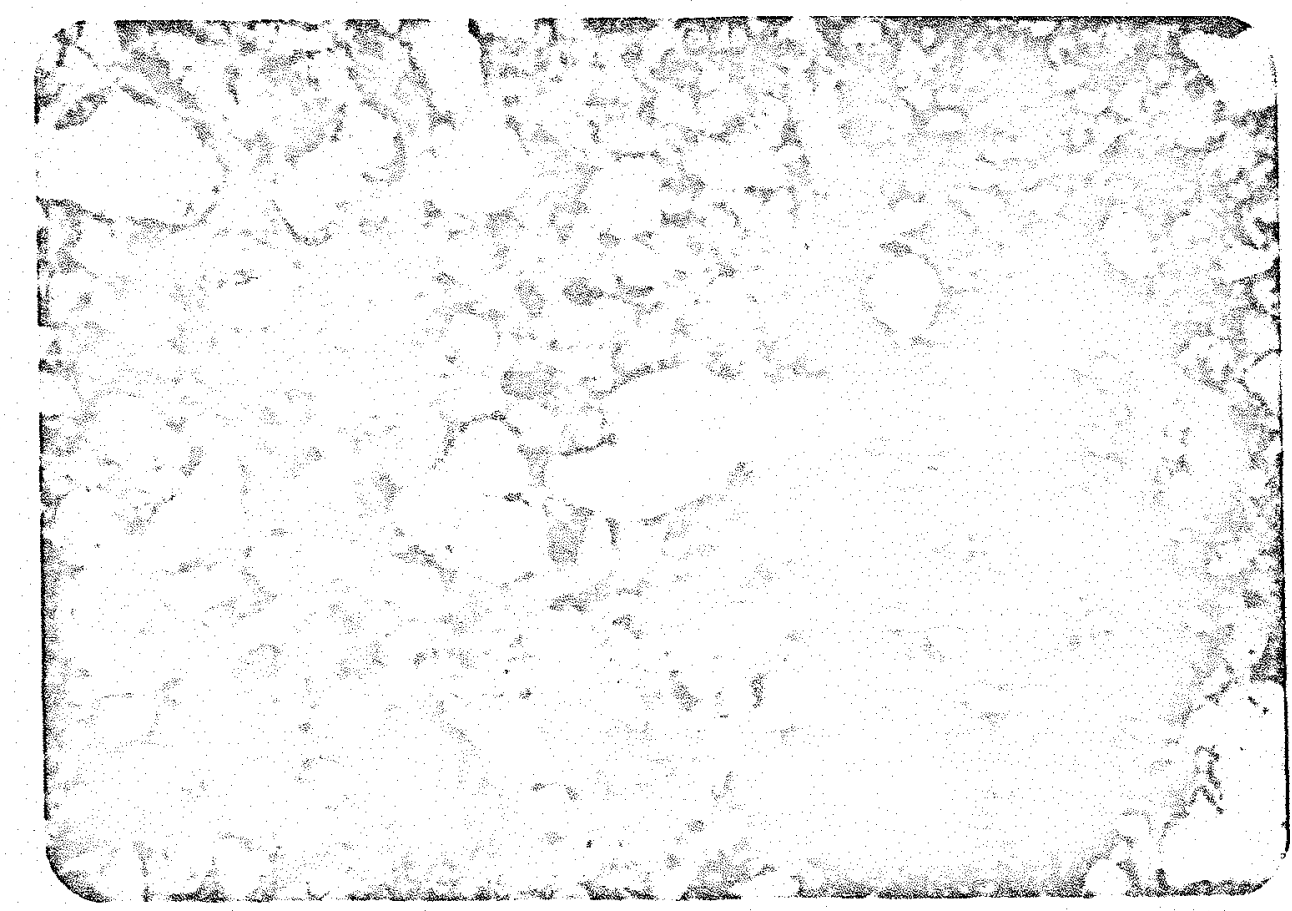

Figura 15 - Fotomicrografia (33X) relativa ao horizonte $A_{3}(10-20 \mathrm{~cm})$ do $P$ e don Bem Drenado do Ecossistema Natural: Sobre um fundo matri= cial de padrão de distribuiçãa enaulic tendendo a monic e contendo um plasma de coloração bruno escuro destaca-se, à direita, um pedotubo com orientação vertical contendo pequenos grãos de quartzo (areia fina e silte crosso)

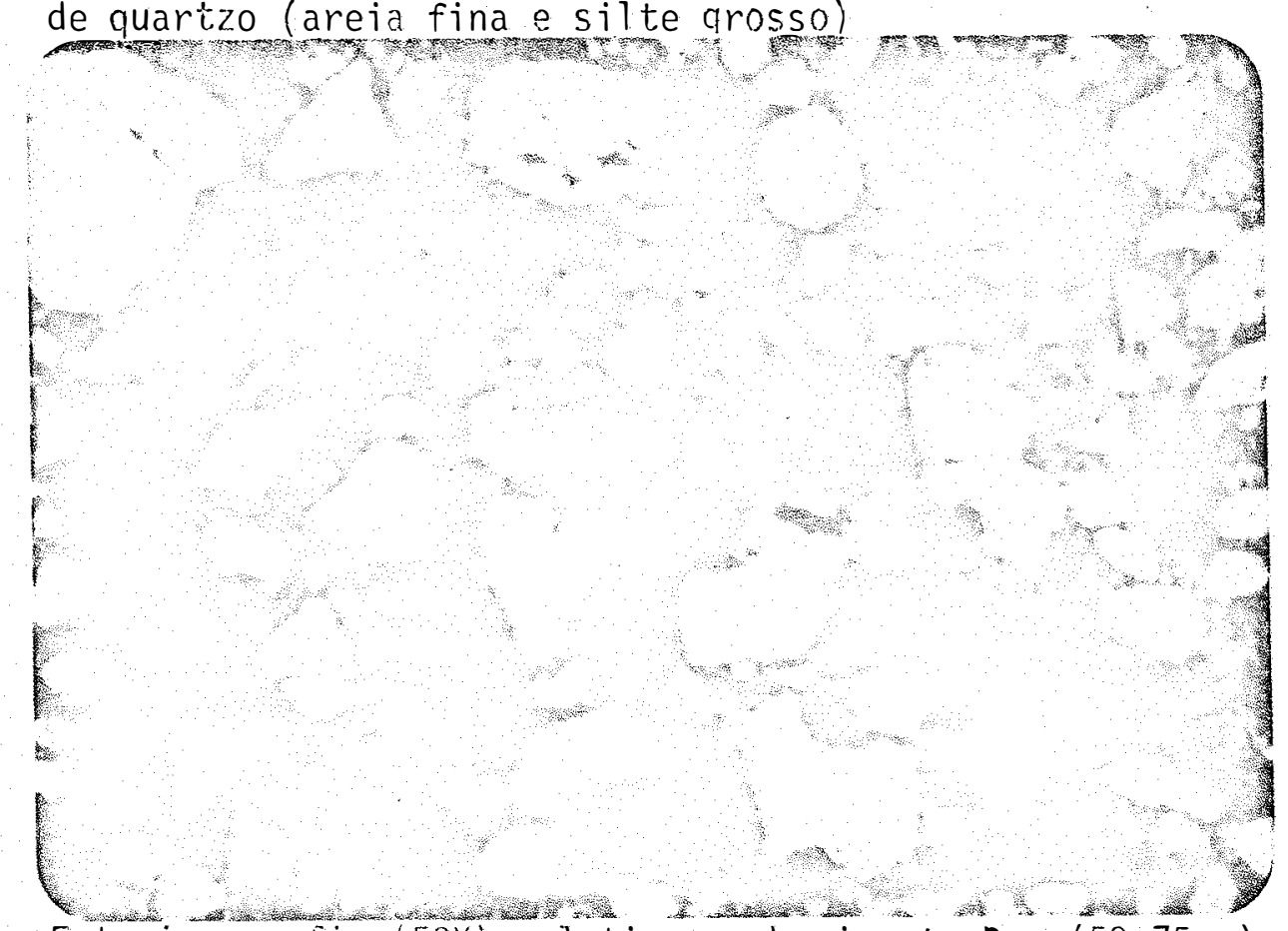

Figura 16 - Fotomicrografia $(53 X)$ relativa ao horizonte $B_{12}(50-75 \mathrm{~cm})$ do Pedon Bem Drenado do Ecossistema Natural: Padrao de distribui ção porfiric onde o plasma é pouco agregado, os grãos de quar $\bar{t}$ zo apresentam-se relativamente agrupados, e a macroporosidade $\bar{e}$ muito reduzida. Note-se depósitos argilosos com limites difusos em torno dos vazios e, à esquerda, a presença de um grão verde de hornblenda. 
originam um padrão bāsico de distribuição tipicamente agrupa do (Figuras 9,11 e 16). O plasma possui coloração variāvel; prōximo a superfície é geralmente bruno escuro (Figuras 7,10 e 15) e em subsuperficie torna-se bruno amarelo com variações entre o alaranjado e o vermelho (Figuras 9,14 e 16). Portan to, apesar das diferenças de textura e drenagem entre os pe dons do ecossistema natural, a organização microestrutural é semelhante. A quantidade de plasma aumenta rapidamente com a profundidade e ocorrem minerais pouco resistentes ao intempe rismo tais como a hornblenda e a staurolita, evidenciando uma alteração mineral ainda incompleta.

A atividade biológica é intensa no horizonte $A$ e o plasma se distribui em função de organizadores biológicos. No horizonte $B$ a microagragação é muito reduzida e a estrutura è continua, apresentando reduzida macroporosidade (Figu ra 16), especialmente nos pedons de textura mais fina (Figuras 9 e 12).

A ocorrência de concentrações plásmicas do tipo argilans ao nivel do horizonte B evidenciam a migração gravi tacional de particulas finas que preenchem parte dos vazios. As manchas avermelhadas (Figura 12) indicam a segregação en tre os compostos de $\mathrm{Fe}$ e os minerais de argila decorrente de condições de redução provocada pela lenta circulação da água no reduzido sistema de macroporos. Este processo estā praticamente ausente no pedon bem drenado o que pode ser atribui do a sua maior macroporosidade decorrente da textura mais grosseira. 
A presença de concentrações endurecidas ricas em plasma e de nódulos férricos ricos em quartzo com limites difu sos indicam haver um processo de evolução. O fato de existirem grãos de quartzo participando da estruturá dos nódulos e do fun do matricial simultaneamente reforça a idéia de que os núdulos' sofrem um processo de fusão que alimenta o fundo matricial (Figu ra 14). Este processo contribui em parte para a formação do pa drão básico de distribuição do tipo agrupado (Figura 12).

A degradação dos nōdulos fërricos, a movimenta ção de particulas finas e a segregação do Fe indicam que a es trutura do solo sofre um processo de desestabilização.

A ausência de microagregação no horizonte $B$ e a presença de minerais pouco resistentes ao intemperismo impedem de se considerar este solo como pertencente ao grupo dos latos solos. Além disto a falta de quantidade adequada de macroporos' que possibilitem o pronto escoamento do excesso de água das chu vas, agravado pelo processo de destabilização da estrutura, in dica que o solo possui um frāgil estado de equilibrio. 


\subsection{Ecossistema Alterado}

No ecossistema alterado foram quantificados os diversos residuos vegetais depositados na superficie e caracterizados os horizontes minerais nas seguintes fases: recēm queimado, cultivado por 1 ano, cultivado por 5 anos e em pousio de 3 anos depois de 2 anos de cultivo.

\subsubsection{Residuos vegetais sobre o solo}

$\mathrm{Na}$ Tabela 7 estão apresentados os pesos dos re siduos vegetais encontrados nas quatro fases anteriormente re feridas, bem como seus conteūdos de $C, N$ e sua relação $C / N$.

\subsubsection{Recēm Queimado}

Apōs a derrubada cqueimada da vegetação do ecossistema natural, a superfície do solo fica coberta por iron cos e galhos parcialmente queimados alëm dos caules e raizes superficiais que não foram destacados do solo.

Do modo como foi efetuada a queimada da área em estudo a superficie do solo ficou coberta em $35 \%$, sendo que $5 \%$ correspondia a ärvores com mais de $60 \mathrm{~cm}$ de circunferencia. Mais de $2 / 3$ da superficie coberta se devia a caules e galhos tomabados e o restante a caules em pé, de diversos diāmetros, e raizes superficiais que por vezes ultrapassam a $5 \mathrm{~cm}$ de diămetro. 


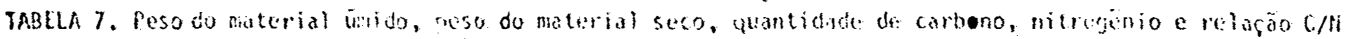
dos residues vegetais depositados ni sunerficic do solo no ecossisteria diterado.

\begin{tabular}{|c|c|c|c|c|c|}
\hline corPoHELTE & $\begin{array}{l}\text { Peso de mate } \\
\text { rial unnioo- }\end{array}$ & $\begin{array}{r}\text { Peso co mate } \\
\text { rial seco } \\
\text { kg /ha }\end{array}$ & crensono & NITROGENIO & $C / N$ \\
\hline & & RECEH QULIMADO & & & \\
\hline Galhos & 6474 & $5837(52)^{d}$ & 2021 & 29,12 & 70 \\
\hline$<\operatorname{cn} \theta$ & 453 & 409 & 148 & 5,24 & 28 \\
\hline $1-3 \mathrm{~cm} 0$ & 2719 & 2451 & 31876 & 323,88 & 379 \\
\hline $3-6 \mathrm{~cm} \theta$ & 3302 & $2977^{\circ}$ & & & \\
\hline Fràgmentos & 4720 & $4570(17)$ & 817 & 47,53 & 15 \\
\hline folhas & 52 & 50 & 15 & - & - \\
\hline gallos & 425 & $4 i i^{\circ}$ & 118 & - & - \\
\hline roizes & 21 & 23 & 7 & $\therefore$ & - \\
\hline frutos & 24 & 23 & 7 & - & - \\
\hline carvão & 906 & 878 & 366 & - & - \\
\hline indiferenciados & 3289 & 3185 & 304 & - & - \\
\hline \multirow[t]{2}{*}{ rotal } & 11194 & $10407(21)$ & 2741 & 76,65 & 36 \\
\hline & & CULTIVADO POR IA & ANO & . & \\
\hline Restos de cuitura & 847 & $665(6,6)$ & 209 & 6,25 & 33 \\
\hline Gathos (vegctaçĩo prim.) & 2335 & $1896(32)$ & 664 & 14,22 & 47 \\
\hline Fragnentos & 807 & $744(78)$ & 216 & 9,45 & 23 \\
\hline forlias & 149 & 136 & 33 & - & - \\
\hline gallios & 374 & 342 & 106 & - & - \\
\hline raizes & 18 & 17 & 5 & . & - \\
\hline carvão & 99 & 97 & 28 & - & - \\
\hline indiferenciados & 167 & 152 & 39 & - & - \\
\hline \multirow[t]{2}{*}{ Total } & 3789 & $3305(19)$ & 1089 & 29,92 & 36 \\
\hline & & CULTIVACO POR $5 \mathrm{~A}$ & iOS & & \\
\hline Galhos (vegetação prin:.) & 563 & $500(142)$ & 178 & 3,15 & 56 \\
\hline Fragmentis & 1149 & $1037(48)$ & 325 & 7,93 & 41 \\
\hline forthas & 388 & 350 & $\therefore 96$ & - & - \\
\hline galthos & 40 & 36 & 13 & - & - \\
\hline carvão & 257 & 232 & 63 & - & - \\
\hline indiferenciados & 464 & 419 & 153 & - & - \\
\hline \multirow[t]{2}{*}{ Total } & 1712 & $1537(80)$ & 503 & 11,13 & 45 \\
\hline & rousio & DE 3 ANOS APOS? & DE CULTIVO & & \\
\hline Folhas & 6658 & $5751(29)$ & 1879 & 78,21 & 24 \\
\hline Gaithos & $6 i 24$ & $5820(64)$ & 2043 & 27,89 & 73 \\
\hline vegetação primäria & 557 & 493 & 205 & 1,43 & 143 \\
\hline vegetaçäo secundäria & 5567 & 532.7 & 1838 & 26,46 & 70 \\
\hline Fragmientos & 2107 & $1857(20)$ & 553 & 20,98 & 26 \\
\hline follias & 1005 & 886 & $=$ & - & - \\
\hline galihos & 59 & 52 & - & - & - \\
\hline carvão & 157 & 138 & - & - & - \\
\hline Indiferenciados & 886 & 781 & - & - & - \\
\hline Total & 14889 & $13428(20)$ & 4475 & 127,08 & 35 \\
\hline
\end{tabular}

a/ Os nüineros entre parenteses correspondem ao cocficiente de variaçäo entre três antostras nas fases Recens queinado, Cultivado for 1 arin e Pousio de 3 anes apōs 2 anos de cultivo, e entre duas ariostras na fase Cultivato por 5 anps. 
Nesta fase foram quantificados os garhos de atë $6 \mathrm{~cm}$ de diâmetro os quais correspondem a $5837 \mathrm{~kg} / \mathrm{ha}$ em peso seco.

Apös a queimada, alëm das partes vegetais par cialmente queimadas, fica sobre o solo uma camada continuasem bora varāvel, composta de carvão e fragmentos vegetais além de grande quantidade de cinzas. Esta camada ē proveniente da quei ma de folhas e galhos da vegetação derrubada e dos próprïcs frag mentos da liteira (Figura 4 ).

A queimada reduz, conforme a sua intensidade, uma maior ou menor quantidade de resîduos vegetais ä carvão e cinzas. Na ärea aqui estudada a queimâda não foi tão intensa e permitiu a permanencia de grande quantidade de material que ñão chegou a queimar.

Os fragmentos perfazem um total de $4570 \mathrm{~kg} / \mathrm{ha}$ em peso seco e são constituidos de cinzas e pedaços de fo Thas, galhos, raĩzes, frutos e carvão. A maior parte deles não foi possîvel identificar a origem, porēm, em mēdia, $1 / 3 \bar{e}$ constitufído de cinzas. A parte indentificável possui mais car vão e fragmentos de galhos.

Excluincio os galhos de diâmetro maior que $6 \mathrm{~cm}$, os quais não foram quantificados, os restos vegetais so bre a superfície do solo correspondem, en peso seco, a $1040 \mathrm{~kg} /$ ha. Os mesmos contēm $2742 \mathrm{~kg} / \mathrm{ha}$ de C, $76,6 \mathrm{~kg} / \mathrm{ha}$ de $N$ e uma re 1 ação Coliv de 36 .

A maior parte do C esta contida nos galhos,prin cipalmente nos de $3-6 \mathrm{~cm}$ de diämetro, e a menor nos fragmentos, 
especialmente nos fragmentos de raizes e frutos os quais cons tituem a menor porção dos fragmentos.

Ao contrário do $C$, o $N$ está contido mais nos frag mentos que nos galhos pois aqueles apresentam uma relação $C / N$ de valor 15, consideravelmente mais baixa que a dos galhos que $\bar{e} d e$ valor 70 .

A relação $C / N$ dos galhos com menos de $1 \mathrm{~cm}$ de diâmetro tambêm è nitidamente mais baixa que a dos galhos de $1-6 \mathrm{~cm}$ de diāmetro (28 contra 78 ).

Com o objetivo de cultivar o solo, o agricul tor, apōs retirar a madeira de lei, efetua a queima dos troncos e galhos, aumentando ainda mais a quantidade de fragmen tos.

Como a queimada è realizada no final da esta çäo seca, com o inîcio das chuvas os fragmentos se decompõem mais intensamente e seus produtos se misturam ao solo juntamen te com os minerais contidos nas cinzas.

\subsubsection{Cultivado por 1 Ano}

O solo sob cultivo apresenta condições propīci as à decomposição dos resĩduos vegetais e ao transporte dos com postos minerais.

Depois de 1 ano de cultivo, grande parte dos troncos e galhos remanescentes apōs a queima sofreram intensa decomposição. 
Na ārea aqui utilizada, ao invēs da queima dos troncos mais grossos (mais de $80 \mathrm{~cm}$ de circunferencia) os mesmos haviam sido dispostos em fileiras de modo a ocuparem as futuras ruas do plantio. Contudo, após 1 ano, a superfície apresentava-se bastante exposta, coberta em menos da metade. Dez por cento da superficie coberta era ocupada pelos troncos, situados nas antigas ruas de plantio, e menos de $40 \%$ por galhos da vegetação primäria e restos de cultura.

Nesta fase a quantidade de resíduos vegetais sobre o solo é de $3305 \mathrm{~kg} / \mathrm{ha}$, em peso seco, dos quais $1896 \mathrm{~kg} / \mathrm{ha}$ correspondem aos galhos remanescentes da vegetação primāria, $665 \mathrm{~kg}$ à folhas secas, caulículos e radículas provenientes da $\bar{u}$ ltima cultura instalada, e $744 \mathrm{~kg}$ à fragmentos vegetais.

os fragmentos vegetais incluem pedaços de caulículos e folhas - estas oriundas da ūltima cultura -, de galhos da vegetação primāria, de raízes e de carvão, além de uma porção indiferenciada que corresponde a $20 \%$ do peso total dos fragmentos.

A maior parte dos fragmentos que podem ser dife renciados é de galhos $(342 \mathrm{~kg} / \mathrm{ha})$ e de folhas $(136 \mathrm{~kg} / \mathrm{ha})$. A quan tidade de carvão proveniente da queima de vegetação primária ē de $97 \mathrm{~kg} / \mathrm{ha}$, consistindo em uma quantidade mais baixa do que se esperaria, o que se deve porēm ao fato do encoivaramento não ha ver sido feito de forma dispersa como nas demais áreas.

A maior quantidade de C está contida nos gaIhos $(664 \mathrm{~kg} / \mathrm{ha})$. Quantidades idênticas deste elemento estão contidas nos restos de cultura $(209 \mathrm{~kg} / \mathrm{ha})$ e nos fragmentos $(2.16 \mathrm{~kg} / \mathrm{ha})$. 
Embora os galhos contenham mais $N$ que os restos de cultura e os fragmentos, estes dois componentes possu em relação $C / N$ mais baixa indicando que, relativamente, a quan tidade de $\mathrm{N}$ é maior nestes componentes.

\subsubsection{Cultivado por 5 Anos}

Depois de 5 anos de cultivo ainda se encontram sobre o solo galhos da vegetação primäria, embora em quantida de bastante reduzida.

Os fragmentos, que tambēm são encontrados, incluem pedaços de folhas, galhos e carvão, alëm de uma parte indiferenciada.

Os fragmentos de folhas provem da vegetação se cundäria, composta principalmente de gramineas, que permanentemente invade a ärea requisitando do agricultor capinas cons tantes. Os fragmentos de galhos e carvão provem da vegetação primāria.

Nesta fase quantificou-se em peso seco, $500 \mathrm{~kg} /$ ha de galhos e $1037 \mathrm{~kg} / \mathrm{ha}$ de fragmentos. Dentre os fragmentos de origem reconhecivel estavam em maior quantidade os de fo Ihas $(350 \mathrm{~kg} / \mathrm{ha})$ e os de carvão $(232 \mathrm{~kg} / \mathrm{ha})$. Os fragmentos ind ferenciados correspondiam a $40 \%$ do total dos fragmentos.

A quantidade de $C$ encontrada nos componentes se gue a mesma ordem dos seus pesos, contudo, os fragmentos possuem conteūdos relativamente menores desse elemento que os ga Ihos. 
Os galhos e os fragmentos embora contendo quan tidades de $C$ proporcionais aos seus pesos possuem relação $C / N$ diferentes. Nos galhos esta relação é maior (56) que nos frag mentos (41).

4.2.1.4. Pousio de 3 Anos Apōs 2 Anos de Cultivo

Com o pousio o desenvolvimento da vegetação se cundāria não é interrompida e, em consequēncia, aumenta a quan tidade de residuos vegetais depositados na superficie.

Dentre estes residuos encontram-se, nas äreas em pousio, folhas da vegetação secundāria, galhos da vegeta ção primāria e da vegetação secundāria e fragmentos diversos. os fragmentos incluem pedaços de folhassgalhos e carvão, a lēm da parte indiferenciāvel.

Nesta fase encontrou-se, em peso seco, $5751 \mathrm{~kg} /$ ha de folhas, $493 \mathrm{~kg} / \mathrm{ha}$ de galhos da vegetação primāria,5327kg /ha de galhos da vegetação secundāria e $1857 \mathrm{~kg} / \mathrm{ha}$ de fragmentos.

Entre os fragmentos diferenciāveis,ocorriam em maior quantidade os de folhas (886 kg/ha) e em menor quantidade os de carvão (138kg/ha) e os de galhos (52kg/ha). Os fragmentos indiferenciados correspondiam a $42 \%$ do total de frag mentos.

A maior parte do C e do $N$ concentram-se nas fó 1has e nos galhos, respectivamente 88 e $83 \%$ do total. 
A relação $C / N \bar{e}$ menor nas folhas e nos fragmen tos, respectivamente 24 e 26 , e maior nos galhos, especialmen te nos galhos da vegetação primāria que é 143. Nos galhos da vegetação secundāria esta relação è de 70 .

\subsubsection{Solo}

Conforme já fo.i discutido (item 4.1.2), o solo do ecossistema natural não é homogēneo, apresentando variações que certamente interagem com os efeitos da alteração do ecossistema. Por este motivo, se procederā a comparação das carac terīsticas do solo nas diversas fases de alteráça levando em conta as variações no ecossistema natural. Para tanto, depois de caracterizados os pedons representativos de cada fase será feita a comparação entre as condições de cada um délés com as do pedon do ecossistema natural selecionado para the servir de padrão. A escolha do padrão foi feita com base na textura obtida atravēs do tato durante a descrição morfolōgica, complementada pelos dados de granulometria do horizonte A através da anālise granulométrica.

Os pedons das fases recém queimado, cultivado por 5 anos e pousio de 3 anos após 2 anos de cultivo possuem texturas semelhantes a do pedon bem drenado: areia franca ou franco arenosa no horizonte $A$ e franco arenosa no horizonte $B$. 0 pedon da fase cultivado por 1 ano possui textura franco argilo arenosa no horizonte $A$ e argilo arenosa a argilosa no ho rizonte $B$, mais semelhante portanto, a do pedon imperfeitamen te drenado do ecossistema natural (Tabela 6). 
Na Figura 17 consta a variação percentual das fra ções granulométricas nas classes de 0-50, 50-200, 200-2000 km e - grau de floculação do horizonte A no ecossistema natural e no ecossistema alterado, obtido a partir dos dados da Tabela 8. 0b serva-se através da figura citada que a semelhança entre o pedon da fase recém queimado e o pedon bem drenado do ecossistema natural ocorre nas trés classes de frações. Por outro lado, os pedons das fases cultivado por 5 anos e pousio de 3 anos se assemelham ao pedon bem drenado na classe de 0-50 $\mu \mathrm{m}$ e ao pedon imperfeitamente drenado na classe de 200-2000 $\mu \mathrm{m}$; contudo, com relação a fração 0-50 $\mathrm{mm}$ se aproximam mais ao pedon moderadamen te que ao imperfeitamente drenado. Já o pedon da fase cultivado por 1 ano é idēntico ao pedon moderadamente drenado na fração

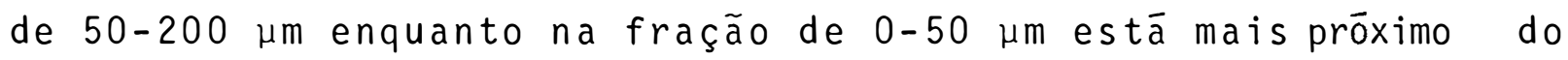
pedon imperfeitamente drenado, ainda que com maior quantidade.

Considerando-se a separação da fração 0-50 $\mu \mathrm{m}$ em frações de 0-2 e 2-50 um (Figura 17) observa-se que os teores da fração 2-50 um são baixos e semelhantes enquanto os teores da fração 0-2 um revelam que o pedon da fase cultivado por 1 ano apresenta maior teor desta fração que os demais.

Quanto ao grau de floculação do horizonte A veri fica-se que existe variações entre os pedons do ecossistema natural: o pedon bem drenado possui maior grau de floculação (54) que os pedons imperfeitamente (48) e moderadamente (36) drenados. Muito embora não haja modificação neste parầmetro na ārea recēm queimada (53), ele decresce sensivelmente nas áreas culti vada por 1 e 5 anos (30 e 22 respectivamente). Na área onde 0 cultivo foi interrompido e esteve em pousio por 3 anos o grau de floculação é 41, equiparável portanto ao do ecossistema natural. 


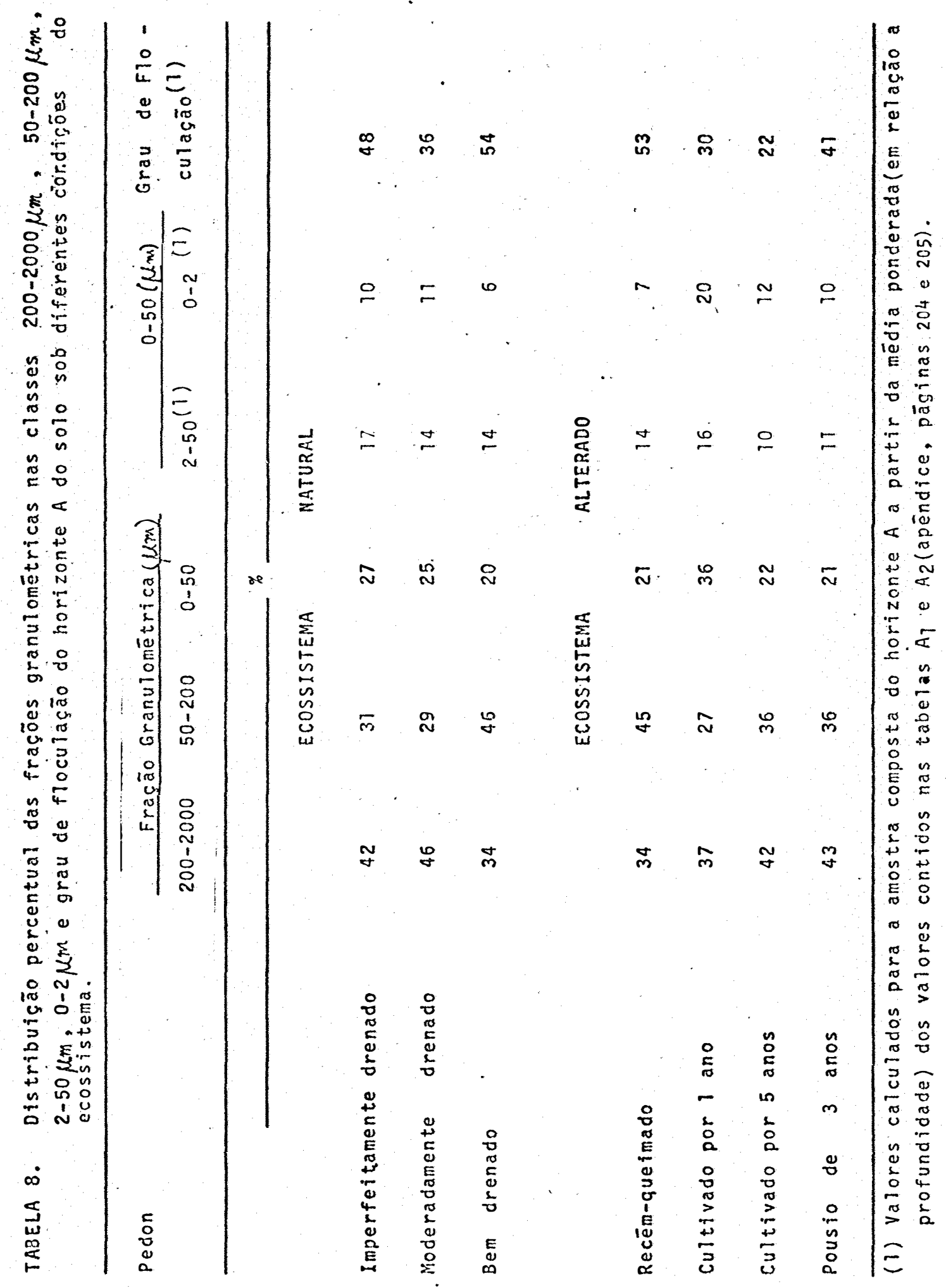




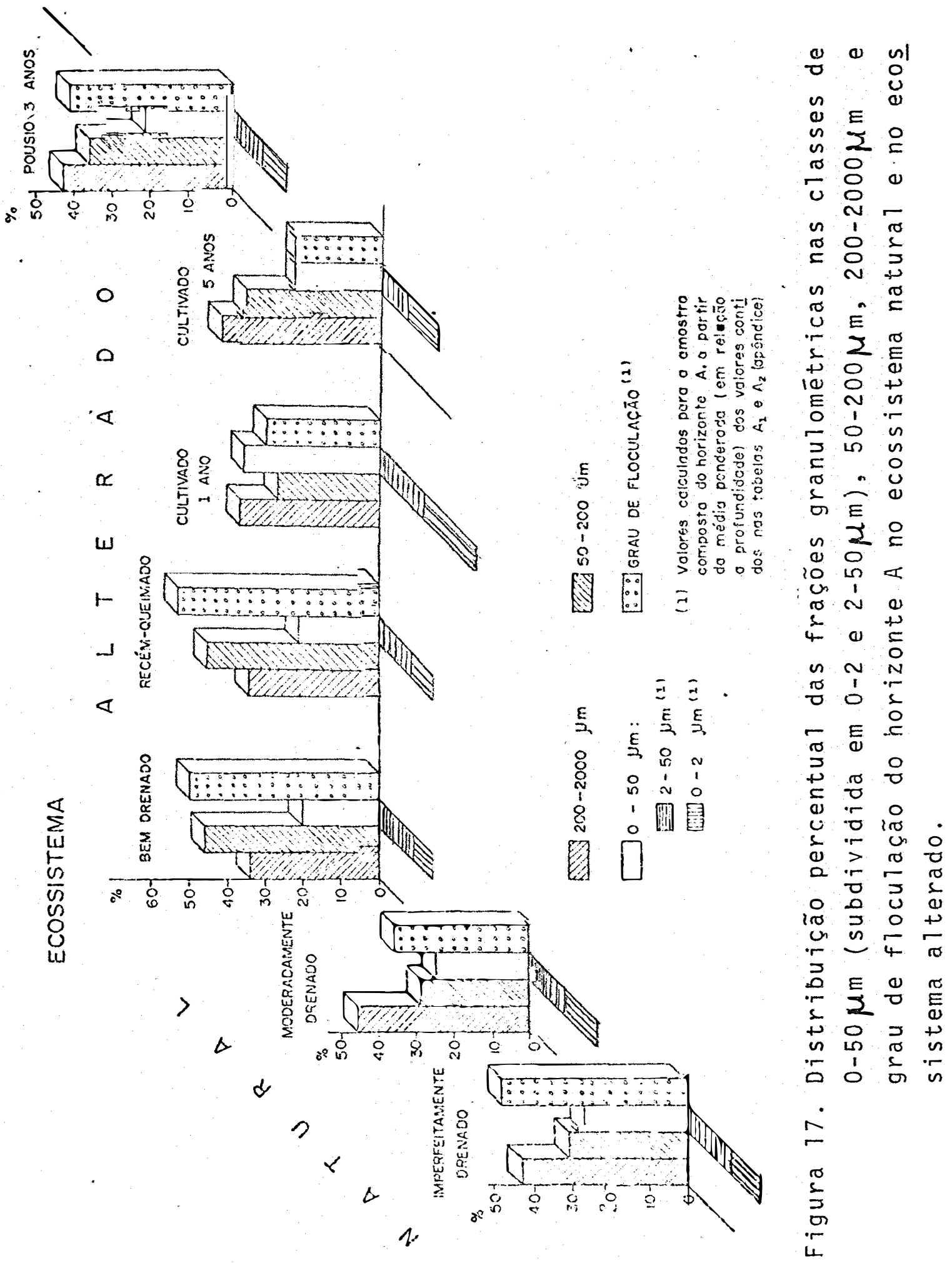


Tabela 9 - Teores de carbono e nitrosenenio totais, relação C/N, valores de - pll em água e $\mathrm{KCl}$ - e $\Delta \mathrm{PH}$ do solo no ecossistema ai terado.

\begin{tabular}{|c|c|c|c|c|c|c|c|}
\hline \multirow{2}{*}{$\begin{array}{l}\text { Hori- } \\
\text { zonte }\end{array}$} & \multirow{2}{*}{$\begin{array}{l}\text { Profun } \\
\text { didade } \\
\text { (cm) }\end{array}$} & \multirow{2}{*}{$C(\%)$} & \multirow{2}{*}{$N(\%)$} & \multirow[t]{2}{*}{$C / N$} & \multicolumn{3}{|c|}{$\mathrm{pH}$} \\
\hline & & & & & $\mathrm{H}_{2} \mathrm{O}$ & $\mathrm{KCl}$ & $\Delta$ \\
\hline \multicolumn{8}{|c|}{ RECEM QUEIMADO } \\
\hline$A_{11}$ & $0=1$ & 2,80 & 0,262 & 10,7 & 7,20 & 6,90 & $-0,30$ \\
\hline$A_{11}$ & $1-4$ & 1,64 & 0,150 & 10,9 & 6,70 & $.6,15$ & $-0,55$ \\
\hline$A_{12}$ & $4-10$ & 0,90 & 0,098 & 9,4 & 5,00 & 4,10 & $-0,90$ \\
\hline$A_{3}$ & $10-20$ & 0,58 & $0,0.53$ & 9,2 & 4,55 & 3,90 & $-0,60$ \\
\hline$B_{11}$ & $20-32$ & 0,39 & 0,040 & 9,8 & 4,65 & 4,00 & $-0,65$ \\
\hline${ }^{B} 12$ & $32-64$ & 0,29 & 0,034 & 8,5 & 4,75 & 4,30 & $-0,45$ \\
\hline$B_{21}$ & $64-85$. & 0,27 & 0,029 & 9,3 & 4,70 & 3,90 & $-0,80$ \\
\hline$B_{22}$ & $85-100$ & 0,21 & 0,022 & 9,5 & 4,90 & 3,90 & $-1,00$ \\
\hline \multicolumn{8}{|c|}{ CULTIVADO POR I AIOO } \\
\hline$A_{11}$ & $0-2$ & 1,77 & 0,181 & 9,8 & 6,15 & 5,55 & $-0,60$ \\
\hline$A_{11}$ & $2-6$ & 1,46 & 0,155 & 9,1 & 5,95 & 5,40 & $-0,55$ \\
\hline$A_{12}$ & $6-75$ & 0,70 & 0,080 & 8,0 & 5,80 & 4,80 & $-1,00$ \\
\hline $\mathrm{A}_{3}$ & $15-25$ & 0,52 & 0,064 & 8,1 & 5,00 & 4,25 & $-0,75$ \\
\hline$B_{11}$ & $25-35$ & 0,39 & 0,040 & $9,8$. & 5,00 & 4,20 & $\cdot 0,80$ \\
\hline$B_{12}$ & $35-75$ & 0,37 & 0,043 & 8,6 & 5,10 & 4,35 & $-0,75$ \\
\hline $\mathrm{B}_{2}$ & $75-100$ & 0,23 & 0,036 & 6,4 & 5,20 & 4,75 & $-0,45$ \\
\hline \multicolumn{8}{|c|}{ CULTIVADO POR 5 ANOS } \\
\hline$A_{1}$ & $0-7$ & 0,89 & 0,082 & 10,8 & 5,75 & 4,95 . & $-0,80$ \\
\hline$A_{3}$ & $7-17$ & 0,59 & 0,059 & 10,0 & 5,85 & 4,90 & $-0,95$ \\
\hline $\mathrm{B}_{11}$ & $17-32$ & 0,36 & 0,036 & 10,0 & 4,80 & 4,05 & $-0,75$ \\
\hline${ }^{B} 12$ & $32-45$ & 0,30 & 0,034 & 8,8 & 4,70 & 3,95 & $-0,75$ \\
\hline $\mathrm{B}_{13}$ & $45-70$ & 0,24 & 0,021 & 11,4 & 4,55 & 3,95 & $-0,60$ \\
\hline$B_{21}$ & $70-95$ & 0,21 & 0,016 & 13,1 & 4,60 & 3,95 & $-0,65$ \\
\hline $\mathrm{B}_{22}$ & $95-100$ & 0,20 & 0,019 & 10,5 & 4,70 & $4 ., 00$ & $-0,70$ \\
\hline \multicolumn{8}{|c|}{ POUSIO DE 3 ANOS APES 2 DE CULTINO } \\
\hline$A_{11}$ & $0-2$ & 1,99 & 0,162 & 12,3 & 5,70 & 4,90 & $-0,80$ \\
\hline$A_{12}$ & $2-7$ & 1,06 & 0,095 & 11,2 & 5,10 & 4,20 & $-0,90$ \\
\hline$A_{3}$ & $7-20$ & 0,72 & 0,067 & 10,8 & 4,90 & 4,15 & $-0,75$ \\
\hline$B_{11}$ & $20-30$ & 0,63 & 0,044 & 12,0 & 4,85 & 3,95 & $-0,90$ \\
\hline${ }^{B} 12$ & $30-40$ & 0,45 & 0,037 & 12,4 & 4,65 & 4,05 & $-0,60$ \\
\hline${ }^{B} 13$ & $40-55$ & 0,36 & $\bullet, 033$ & 10,6 & 4,85 & 4,10 & $-0,75$ \\
\hline$B_{2.1}$ & $55-75$ & 0,26 & 0,021 & 11,9 & 4,75 & 4,05 & $-0,70$ \\
\hline$B_{22}$ & $75-100$ & 0,21 & 0,024 & 8,8 & 4,60 & 4,00 & $-0,60$ \\
\hline
\end{tabular}


Em que pesem as variações na granulometria, se pode estabelecer, combase principalmente na quantidade das fraçöes mais finas (silte mais argila), certa semelhança entre cada um dos pedons correspondentes às quatro fases do ecossistema alterado e um ou mais pedons do ecossistema natural. Assim, a escolha dos padrões foi estabelecida como segue: pedon imperfei tamente drenado como padrão do pedon referente a fase cultivada por 1 ano, pedon bem drenado como padrão do pedon da fase recém queimado; pedons bem e moderadamente drenados como padröes dos pedons referentes as fases cultivado por 5 anos e pousio de 3 anos. Sempre que possível são feitas comparações considerandose as très classes de drenagem do solo no ecossistema natural.

\subsubsection{Recēm Queimado}

Na Tabela 9 encontram-se os teores de $\mathrm{C}, \mathrm{N}$ e a relação $C / N$ do solo após a queimada e nas demais fases do ecossistema alterado e na Tabela 10 o conteūdo de $C$ e $N$ até $100 \mathrm{~cm}$ de profundidade do solo no ecossistema natural e no ecossistema alterado.

Tabela 10. Conteūdo de carbono e nitrogenio atē $100 \mathrm{~cm}$ de profundidade do so 10. Ecossistema natura7: $N_{7}$ - Imperfeitamente drenado; $N_{2}$ - Mode radamente drenado; $N_{3}-$ Bem drenado. Ecossistema alterado: $Q-r e$ rém-queimado; A - cultivado 1 ano; I - cultivado 5 anos; $P$ - pou sio de 3 anos (após 2 anos de cultivo).

\begin{tabular}{|c|c|c|c|c|c|c|c|}
\hline \multirow{2}{*}{ ELEMENTO } & \multicolumn{3}{|c|}{ NATURAL } & \multicolumn{4}{|c|}{ ALTERADO } \\
\hline & $N_{1}$ & $\mathrm{~N}_{2}$ & $N_{3}$ & $Q$ & A & I & $P$ \\
\hline & & & & $\mathrm{Kg} / \mathrm{m}^{2}-$ & & & \\
\hline Carbono & 6,29 & 6,84 & 6,58 & 6,33 & 6,74 & 5,65 & 6,50 \\
\hline Nitrogenio & 0,67 & 0,58 & 0,65 & 0,68 & 0,81 & 0,53 & 0,59 \\
\hline
\end{tabular}


4.2.2.1.1. Carbono e Nitrogênio

0 teor de $C$ é bem mais elevado na superfície que em profundidade. 0 horizonte superficial $\left(A_{11}, 0-4 \mathrm{~cm}\right)$ apresenta um valor maior que $1,64 \%$ e sua parte superior, de $1 \mathrm{~cm}$ de espes sura, mais rica em residuos vegetais, possui $2,80 \%$ de C total (Tabela 9).

Nos horizontes seguintes $\left(A_{12}\right.$ e $\left.A_{3}\right)$ e o teor de $C$ diminui sensivelmente para 0,90 e 0,58 (respectivamente) e da $\overrightarrow{7}$ em diante diminui gradualmente até o valor de $0,21 \%$ no horizon te $B_{22}$ à $85-100 \mathrm{~cm}$ de profundidade.

A quantidade de C armazenada até $100 \mathrm{~cm}$ è de $6,33 \mathrm{~kg} /$ ha enquanto no pedon correspondente do ecossistema natural, o bem drenado, è $6,58 \mathrm{Kg} / \mathrm{ha}$ (Tabela 10 ).

0 teor de $\mathrm{N}$ tambēm é mais elevado no horizonte su perficial (superior a $0,150 \%$ no $A_{11}$ ) especialmente na parte su perior $(0,262 \%)$, devido a maior quantidade de residuos vegetais (Tabela 9).

Nos horizontes $A_{12}$ e $A_{3}$, diminui para 0,098 e $0,063 \%$, respectivamente, e da ỉ em diante o decréscimo é gradual até atingir o valor de $0,022 \%$ no horizonte $B_{22}$.

A quantidade de $\mathrm{N}$ armazenada até $100 \mathrm{~cm}$ è de $0,679 \mathrm{Kg} /$ $\mathrm{m}^{2}$, aproximada a encontrada no pedon bem drenado do ecossistema natural $\left(0,651 \mathrm{~kg} / \mathrm{m}^{2}\right)$.

A relação C/N tambēm apresenta valores mais eleva dos na superfície. No horizonte $A_{11}$ estā em torno de 10,8 e nos demais é pouco variāvel em torno do valor 9,28 0,44 (Tabela 8 ), não diferindo substancialmente da encontrada no ecossistema na 
tural, no pedon bem drenado (Tabela 3 ).

$$
\text { 4.2.2.1.2. } \mathrm{pH}
$$

A Tabela 9 comtēm os valores de pH tanto na fase recēm queimado como nas demais fases de alteração do ecossistema.

$\mathrm{Na}$ fase recém queimado tambēm o pH do horizonte su perficial apresenta-se bastante alterado em consequéncia da in corporação das cinzas, ricas em bases, provenientes da queimada. 0 primeiro centimetro do horizonte $A_{11}$ possui um valor de $\mathrm{pH}$ em $\mathrm{H}_{2} \mathrm{O}$ de 7,20 e o restante do horizonte 6,7 . Estes valores são consideravelmente mais elevados que os encontrados no ecossiste ma natural, especialmente os do pedon bem drenado (Tabela 3 ).

A partir do horizonte $A_{12}$ ocorre um decréscimo de 2 unidades. Deste horizonte até o horizonte $B_{22}$ os valores de pH em $\mathrm{H}_{2} \mathrm{O}$ oscilam em torno de $4,75 \pm 0,20$ ainda mais elevados que os do pedon bem drenado do ecossistema natural.

0 padrão de distribuição dos valores de $\mathrm{pH}$ em $\mathrm{KCl}$ è idêntico ao do $\mathrm{pH}$ em $\mathrm{H}_{2} \mathrm{O}$,porēm hā diferenças na magnitude de variação dos valores do $\Delta$ pH. Estes são menos negativos na super fície e hā tendência de aumento ao nível do horizonte $A_{12}$. A partir dai torna a decrescer até o horizonte $B_{12}(32-64 \mathrm{~cm})$ pas sando a aumentar da $\bar{i}$ até o horizonte $B_{22}(85-100 \pm \mathrm{cm})$ (Tabela' $9)$.

\subsection{Complexo de Troca Iônica}

Na Tabela 11 encontram-se os dados referentes a 0 complexo de troca iōnica do ecossistema alterado.

o complexo de troca iônica na fase recēm queimado 
Tabela 11 - Cátions trocáveis, soma de bases (S), capacidade de troca de cátions $(T)$ e valor de saturação em bases ( $(\%)$ do solo no ecossistema alterado.

Hori- Profundi-
zonte dade $(\mathrm{cm})$$\frac{\mathrm{Ca}^{+2} \mathrm{Mg}^{+2} \mathrm{Na}^{+1} \mathrm{~K} \% \mathrm{l}}{\mathrm{emg} / \mathrm{lo0g} \text { solo }} \frac{\mathrm{S}}{\begin{array}{c}\text { emg/lo0g } \\ \text { solo }\end{array}} \frac{\mathrm{H}^{+1} \mathrm{Al}^{+3}}{\begin{array}{c}\mathrm{eng} / \mathrm{l00g} \\ \text { solo }\end{array}} \frac{\mathrm{T}}{\begin{array}{c}\text { eng/100g } \\ \text { solo }\end{array}} \mathrm{V} \%$

\section{RECEM QUEIMADO}

$\begin{array}{llllllllllll}A_{11} & 0-1 & 5,14 & 2,21 & 0,61 & 1,01 & 8,97 & 0,23 & 0,02 & 9,22 & 97 \\ A_{11} & 1- & 4 & 3,02 & 0,83 & 0,14 & 0,37 & 4,36 & 0,22 & 0,02 & 4,60 & 95 \\ A_{12} & 4-10 & 0,69 & 0,29 & 0,05 & 0,12 & 1,15 & 0,25 & 0,03 & 1,43 & 80 \\ A_{3} & 10-20 & 0,21 & 0,11 & 0,06 & 0,16 & 0,54 & 0,77 & 0,19 & 1,50 & 36 \\ B_{11} & 20-32 & 0,07 & 0,05 & 0,06 & 0,12 & 0,30 & 0,78 & 0,28 & 1,36 & 22 \\ B_{12} & 32-64 & 0,10 & 0,06 & 0,03 & 0,05 & 0,24 & 0,80 & 0,28 & 1,32 & 18 \\ B_{21} & 64-85 & 0,08 & 0,07 & 0,04 & 0,07 & 0,26 & 0,94 & 0,34 & 1,54 & 17 \\ B_{22} & 85-100 & 0,06 & 0,10 & 0,02 & 0,01 & 0,19 & 1,02 & 0,31 & 1,49 & 13\end{array}$

CULTIVADO POR I AHO

$\begin{array}{llllllllllll}\mathrm{A}_{11} & 0- & 2 & 4,38 & 0,91 & 0,04 & 0,48 & 5,81 & 0,26 & 0,04 & 6,11 & 95 \\ \mathrm{~A}_{11} & 2- & 6 & 3,81 & 0,60 & 0,03 & 0,28 & 4,72 & 0,25 & 0,04 & 5,01 & 94 \\ \mathrm{~A}_{12} & 6- & 15 & 1,79 & 0,52 & 0,02 & 0,08 & 2,41 & 0,25 & 0,04 & 2,70 & 89 \\ \mathrm{~A}_{3} & 15-25 & 1,22 & 0,23 & 0,02 & 0,13 & 1,60 & 0,30 & 0,20 & 2,10 & 76 \\ \mathrm{~B}_{11} & 25-35 & 0,37 & 0,13 & 0,02 & 0,13 & 0,65 & 0,38 & 0,23 & 1,26 & 52 \\ \mathrm{~B}_{12} & 35-75 & 0,59 & 0,20 & 0,02 & 0,06 & 0,87 & 0,30 & 0,14 & 1,31 & 66 \\ \mathrm{~B}_{2} & 75-100 & 0,63 & 0,42 & 0,02 & 0,06 & 1,13 & 0,25 & 0,02 & 1,40 & 81\end{array}$

CULTIVADO POR 5 ANCS

$\begin{array}{llllllllllll}\mathrm{A}_{1} & 0-7 & 2,01 & 0,28 & 0,03 & 0,08 & 2,40 & 0,21 & 0,02 & 2,63 & 91 \\ \mathrm{~A}_{3} & 7-17 & 1,64 & 0,12 & 0,02 & 0,02 & 1,80 & 0,26 & 0,04 & 2,10 & 86 \\ \mathrm{~B}_{11} & 17-32 & 0,20 & 0,02 & 0,02 & 0,02 & 0,26 & 0,78 & 0,34 & 1,38 & 19 \\ \mathrm{~B}_{12} & 32-45 & 0,05 & 0,01 & 0,02 & 0,02 & 0,10 & 0,72 & 0,37 & 1,19 & 8 \\ \mathrm{~B}_{13} & 45-70 & 0,04 & 0,01 & 0,02 & 0,01 & 0,08 & 0,83 & 0,39 & 1,30 & 6 \\ \mathrm{~B}_{21} & 70-95 & 0,05 & 0,02 & 0,02 & 0,01 & 0,10 & 0,81 & 0,53 & 1,40 & 7 \\ \mathrm{~B}_{22} & 95-100 & 0,04 & 0,02 & 0,02 & 0,01 & 0,09 & 0,98 & 0,52 & 1,59 & 6\end{array}$

POUSIO DE 3 ANOS APOS 2 ANOS DE CULTIVO

$\begin{array}{llllllllllll}\mathrm{A}_{11} & 0- & 2 & 2,70 & 0,71 & 0,08 & 0,43 & 3,92 & 0,24 & 0,04 & 4,20 & 93 \\ \mathrm{~A}_{12} & 2- & 7 & 1,43 & 0,25 & 0,03 & 0,09 & 1,80 & 0,42 & 0,18 & 2,40 & 75 \\ \mathrm{~A}_{3} & 7-20 & 1,03 & 0,12 & 0,02 & 0,04 & 1,21 & 0,47 & 0,24 & 1,92 & 63 \\ \mathrm{~B}_{11} & 20-30 & 0,37 & 0,07 & 0,02 & 0,02 & 0,48 & 0,65 & 0,40 & 1,53 & 31 \\ \mathrm{~B}_{12} & 30- & 40 & 0,18 & 0,06 & 0,02 & 0,02 & 0,28 & 0,72 & 0,53 & 1,53 & 18 \\ \mathrm{~B}_{13} & 40-55 & 0,19 & 0,05 & 0,02 & 0,01 & 0,27 & 0,74 & 0,45 & 1,46 & 18 \\ \mathrm{~B}_{21} & 55-75 & 0,10 & 0,04 & 0,02 & 0,01 & 0,17 & 0,64 & 0,44 & 1,26 & 14 \\ \mathrm{~B}_{22} & 75-100 & 0,07 & 0,03 & 0,02 & 0,01 & 0,13 & 0,57 & 0,46 & 1,16 & 11\end{array}$


ainda acha-se influenciado pela matēria orgānica, contudo há também um efeito marcante das cinzas incorporadas no solo, espe cialmente nos horizontes superficiais:

Os teores de bases trocāveis são muito mais eleva dos no horizonte $A_{1}$. Calculando-se a média ponderada - em fun ção da espessura das camadas onde foram coletadas as amostras que representam éste horizonte - obtém-se um valor de 5,5l emg de basespor $100 \mathrm{~g}$ de solo. A partir do horizonte $A_{12}$ a soma de bases decresce progressivamente de um valor de 1,15 para 0,19 emg/l00g de solo no horizonte $B_{22}$.

Com os teores de $H+A l$ trocāveis ocorre o inver so: os valores são mais baixos nos horizontes $A_{11}(0,24$ emg/100 g) e $A_{12}(0,28 \mathrm{emg} / 100 \mathrm{~g})$ que nos demais horizontes. Contudo os aumentos a partir do horizonte $A_{3}$ até o horizonte $B_{22}$ são gra duais.

Em decorrência da distribuição nos teores de cáti ons trocāveis, o valor $T$ é bem mais elevado no horizonte A 11 $(5,76 \mathrm{emg} / 100 \mathrm{~g}$ - média ponderada), além de fortemente influen ciado pelas bases. Por outro lado, a partir do horizonte $A_{12}$ es tā em torno de $1,44 \pm 0,09$ emg/lo0g (mēdia aritimētica) e é mais influenciado pelo H e Al trocáveis, especialmente por este üt timo.

0 balanço entre a soma das bases e a soma do $H+A l$ trocáveis acarreta a ocorrência de valores $V$ elevados nos horizontes $A_{11}$ (96\%, média ponderada) e $A_{12}(80 \%)$, muito embora nes te ūitimo o valor T seja bem mais baixo $(1,43 \mathrm{emg} / 100 \mathrm{~g})$ que na quele $(5,76 \mathrm{emg} / 100 \mathrm{~g})$. Nos demais horizontes, onde os valores de T também são equiparāveis ao do horizonte $A_{12}$, os valores de 
$V$ decrescem progressivamente de $36 \%$, no horizonte $A_{3}$, até $13 \%$, no horizonte $B_{22}$.

Em comparação ao ecossistema natural, o complexo de troca iōnica do pedon na fase recém queimado possui mais bases e menos $H+A l$ trocāveis no horizonte $A_{11}(0-4 \mathrm{~cm})$ que os três pedons do ecossistema natural. No horizonte $B$ os valores $S$ e $V$ são superiores aos do pedon bem drenado; idênticos aos do pedon moderadamente drenado.e inferiores aos pedon imperfeita mente drenado.

Comparando-se os dados apresentados com os do pe don correspondente no ecossistema natural, verifica-se que o ho rizonte $A_{11}$ do solo nesta fase possui 1,54 emg/lo0g a mais de bases, o que, em termos relativos é menos que os $0,17 \mathrm{emg} / 100 \mathrm{~g}$ de aumento encontrado no horizonte $A_{12}$ em diante. Quanto ao teor de $H+A l$ trocáveis, embora não haja grande variação, em termos absolutos, nos decréscimos, em termos relativos, a redu ção é maior nos horizontes $A_{11}$ e $A_{12}$. Em consequência, o valor T aumenta em termos absolutos cerca de 1,2 emg/100g, no horizon te $A_{11}$ e diminui discretamente no horizonte $A_{12}$. Em termos rela tivos, tanto 0 aumento no horizonte $A_{11}$ quanto a diminuição nos demais horizontes não são acentuados. Portanto,o fato do valor $S$ ser mais elevado - especialmente no horizonte $A_{11}$ - e o teor. de $H+A l$ trocáveis mais baixo - principalmente no horizonte $A_{12}$ - indica que os efeitos da mudança de pH se refletem imediatamente sobre o complexo de troca iónica.

4.2.2.1.4. Densidade e Porosidade

A Tabela 12 contēm os dados refrentes a textura, 
Tabela 12 - Classes de textura e valores de densidade e porositade do sulo no ecos sistema alterado.

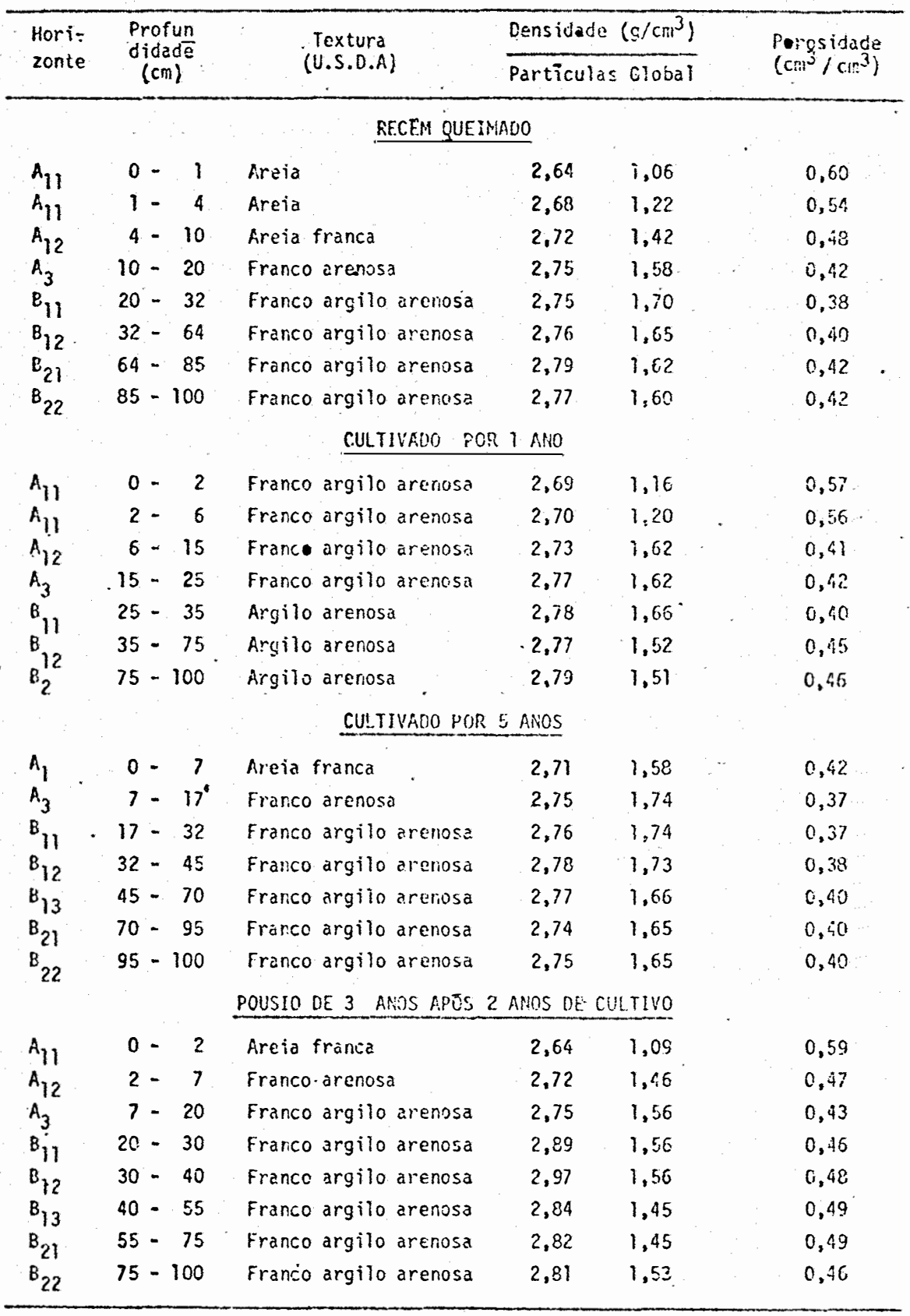


densidade e porosidade do ecossistema alterado.

Na fase recém queimado a densidade de partĩculas é ligeiramente mais baixa no horizonte $A_{11}\left(2,68 \mathrm{~g} / \mathrm{cm}^{3}\right)$, especial mente na parte superior $\left(2,64 \mathrm{~g} / \mathrm{cm}^{3}\right)$ devido ao conteūdo de materia orgânica ser maior neste horizonte, contudo não se afasta muito do valor médio calculado entre todos os horizontes $(2,73 \pm$ $0,05 \mathrm{~g} / \mathrm{cm}^{3}$ ) (Tabella 6 ). Em comparação ao pedon correspondente' no ecossistema natural estes valores s̃o mais baixos.

A densidade do solo é nitidamente mais baixa no ho rizonte $A_{11}\left(1,22 \mathrm{~g} / \mathrm{cm}^{3}\right)$ igualmente influenciada pelo mais ele vado teor de matéria orgànica. No horizonte $A_{12}$ ainda é ligeira mente menor $\left(1,42 \mathrm{~g} / \mathrm{cm}^{3}\right)$ que nos demais horizontes os quais va riam em torno de $1,63 \pm 0,05 \mathrm{~g} / \mathrm{cm}^{3}$ (Tabela 6 ).

Quanto a porosidade, se observa a ocorrência de va lores mais elevado nos horizontes $A_{11}$ e $A_{12}$, os quais correspon dem a um valor médio ponderado - em relação a espessura - de $0,51 \mathrm{~cm}^{3} / \mathrm{cm}^{3}$. A partir do horizonte $A_{3}$ os valores da porosidade' estao em torno de $0,41+0,02 \mathrm{~cm}^{3} / \mathrm{cm}^{3}$. No pedon bem drenado do ecossistema natural o horizonte $A_{11}$ tem uma porosidade de 0,61 $\mathrm{cm}^{3} / \mathrm{cm}^{3}$ (Tabela 6 ), enquanto nos demais estā em torno de $0,45 \pm$ $0,02 \mathrm{~cm}^{3} / \mathrm{cm}^{3}$, portanto mais elevados que os do pedon da fase re cēm queimado.

\subsubsection{Cultivado por 1 Ano}

Em comparação ao ecossistema natural observa-se di ferenças mais acentuadas na quantidade de $N$ armazenada (Tabela' 10), no pH (Tabela 9), nos cátions trocāveis e no valor V\% ( Ta bela 11). 


\subsection{Carbono e Nitrogēnio}

Nesta fase o teor de C continua mais elevado na superficie embora em um nível mais baixo do que no pedon imperfeitamente drenado do ecossistema natural. O horizonte $A_{11}$ pos sui $1,77 \%$ de C na parte superior $(0-2 \mathrm{~cm})$ e $1,64 \%$ na inferior $(2-6 \mathrm{~cm})$, enquanto a $A_{12}(6-15 \mathrm{~cm}) 0,70 \%$. A partir do horizonte $A_{3}(15-25 \mathrm{~cm})$ o teor desse elemento decresce de 0,52 a $0,23 \%$ no horizonte $B_{2}\left(75-100^{+} \mathrm{cm}\right)$ (Tabela 11$)$.

A quantidade de C armazenada de 0 a $100 \mathrm{~cm}$ é de $6,74 \mathrm{~kg} / \mathrm{m}^{2}$, superior a encontrada no pedon imperfeitamente drena do $\left(6,29 \mathrm{~kg} / \mathrm{m}^{2}\right)$ que the é adjacente e serve de padrão. Isto se deve a uma maior acumulação desse elemento na faixa de $20-100 \mathrm{~cm}$ do perfil na fase de 1 ano de cultivo. Observa-se todavia que nos dez primeiros centímetros houve uma diminuição de $0,24 \mathrm{~kg} /$ $m^{2}$ de C em relação ao pedon citado (Tabela 14).

Após um ano de cultivo os teores de $N$ do solo são, na maioria dos horizontes, superiores aos do ecossistema natural, resultando uma quantidade armazenada até $100 \mathrm{~cm}$ de profundidade tambëm maior $\left(0,81\right.$ contra $0,67 \mathrm{~kg} / \mathrm{m}^{2}$ no perfil imperfeitamente drenado) (Tabela 10). Contudo deve-se considerar que o pedon representativo desta fase possui teores mais elevados de particulas finas que 0 do ecossistema natural (Tabela 8 ). 
Do mesmo modo que o pedon do ecossistema natu ral que lhe é correspondente, a relação $C / N$ é mais elevada na superficie do solo cultivado por 1 ano, contudo os valores são mais baixos. A partir do horizonte $A_{12}$ a média aritimética é de $8,18 \pm 1,23$, enquanto no pedon imperfeitamente drenado do ecóssistema natural até $100 \mathrm{~cm}$ é $9,07 \pm 1,27$.

A ocorrēncia de valores relativamente menores de relação $C / N$ nesta fase em comparação ao ecossistema natural é consequência do maior teor de $N$ (Tabelas 3 e 9 ).

\section{$4.2 .2 .2 .2 . \mathrm{pH}$}

Em relação ao ecossistema natural o pH ainda per manece elevado após 1 ano de cultivo. No horizonte $A_{1} \bar{e} 6,00$, em água, e 5,45 em KCl, enquanto no horizonte $A_{12} \bar{e} 5,80$ e 4,80 ( Tabela 9).

A partir do horizonte $A_{3}$ os valores de $\mathrm{pH}$ oscilam em torno de $5,10 \pm 0,10$, em ägua, e 4,40£0,25 em KCl, acusando, portanto, valores mais elevados na superficie que em profundidade, ao conträrio do solo no ecossistema natural (Tabelas 3 e 9 ). Isto se deve a permanēncia dos efeitos causados pelas bases contidas nas cinzas incorporadas após a queimada.

Os valores de $\mathrm{pH}$ aumentam até o horizonte $A 12$ e decrescem daĩ em diante (Tabela 9), configurando um padrão contrário ao do ecossistema natural que diminui até o horizonte $\mathrm{A}_{3}$ e aumenta a partir do horizonte $\mathrm{B}$ (Tabela 3 ). 


\subsection{Complexo de Troca Iónica}

Os valores de $S$, do mesmo modo que no ecossistema natural, são mais elevados na superfície que em profundi dade. Contudo os valores são maiores no pedon representativo de 1 ano de cultivo, especialmente em profundidade.

os valores de T tambēm são mais elevado, todavia a diferença encontrada em profundidade é menor que a veri ficada com as dos valores de $S$.

A ocorrência de valor $T$ maior no horizonte $A$ em comparação ao do ecossistema natural se deve à liberação de cargas dependentes do $\mathrm{pH}$.

Os valores de $V$ são maiores tanto na superfíci e como em profundidade sendo que as maiores diferenças ocor em nos horizontes compreendidos entre $6-50 \mathrm{~cm}$. 0 valor médio de $V$ entre estes horizontes é de $71 \%$ (Tabela 11), bem mais elevado que os do pedon correspondente no ecossistema natural onde este valor é de $23 \%$ (Tabela 5 ).

Os aumentos verificados no valor V provavelmen te são decorrentes ainda da adição das bases na fase recēm quei mado e cuja a remoção não é facilitada nesta condição de drenagem .

A diminuição do teor de $H+A l$ trocāveis se dá em consequência da adição das bases, contudo na superfície a ausēncia da acidez causada pela decomposição da liteira tambēm contribui para isto. 


\subsection{Densidade e Porosidade}

A densidade de partículas é pouco variāvel. A média en tre os horizontes é de $2,75 \pm 0,04 \mathrm{~g} / \mathrm{cm}^{3}$ (Tabela 12), ligeiramente maior que a do pedon imperfeitamente drenado do ecossistema natural (Tabela 6).

A densidade do solo é semelhante a obtida no ecossistema natural - pedon imperfeitamente drenado - em profundidade, o mesmo não acontecendo na parte superior do perfil. O horizonte $A_{1}(0-15 \mathrm{~cm})$ possui valores de densidade do solo maiores (Tabelas 6 e 12).

Com relação a porosidade total também ocorrem va riações: apresenta-se maior que no ecossistema natural na parte superior do horizonte $A_{11}(0-2 \mathrm{~cm})$ e nos horizontes $B_{12}$ e $B_{2}$. No horizonte $\mathrm{A}_{12}$ embora tenha havido um aumento de densidade do solo não ocorreu uma maior diminuição na porosidade devido ao fato da densidade de particulas ser maior que a do ecossistema natural.

\subsubsection{Cultivado por 5 Anos}

Nesta fase, embora persistam mudanças ocorridas no pH, as diferenças mais acentuadas são no teor de C (Tabela 9), na densidade global, na porosidade (Tabela 12), na soma de bases e consequentemente no valor V (Tabela 11).

\subsection{Carbono e Nitrogēnio}

Após 5 anos de cultivo os teores de C são nitida mente mais baixos que os encontrados no ecossistema natural. Até a profundidade de $100 \mathrm{~cm}$ existe armazenado $5,65 \mathrm{~kg} / \mathrm{m}^{2}$ de $C$ enquanto no pedon moderadamente drenado do ecossistema natural $\bar{e}$ de $6,84 \mathrm{~kg} / \mathrm{m}^{2}$. Mesmo nos pedons. correspondentes as clas- 
ses bem e imperfeitamente drenados do ecossistema natural, cu jas quantidades de C armazenada são menores que a do pedon mo deradamente drenado (respectivamente 6,58 e $5,29 \mathrm{~kg} / \mathrm{m}^{2}$ até 100 cm) ainda assim são consideravelmente mais elevadas que no pe don desta fase.

A quantidade de $\mathrm{N}$ armazenada tambēm è inferior a do ecossistema natural, porēm, não tanto quantó a de C. Atē $100 \mathrm{~cm}$ existem armazenados nesta fase $0,53 \mathrm{~kg} / \mathrm{m}^{2}$. No ecossistema natural a menor quantidade encontrada atē a referida profundidade foi no pedon moderadamente drenado: $0,58 \mathrm{~kg} / \mathrm{m}^{2}$.

A relação $C / N$ è de 10,8 no horizonte $A_{1}(0-7 \mathrm{~cm})$ e estā em torno de $10,6 \pm 1,47$ no horizonte $B$. Jā no pedon bem drenado do ecossistema natural, os horizontes $A_{11}$ e $A_{12}$ possu em relação $C / N$ de 11,9 e 10,1 , respectivamente, enquanto no horizonte B estā em torno de 9,78 $\pm 0,97$.

\subsubsection{2. $\mathrm{pH}$}

Mesmo após 5 anos de cultivo o pH continua mais elevado na superficie (horizonte $A$ ) que no ecossistema natural. Nos horizontes $A_{1}$ e $A_{3}$ os valores de $p H$ são praticamen te os mesmos: 5,80 em àgua e 4,90 em KCl. Nestes mesmos horizontes do ecossistema natural os valores mais altos encontrados foram 4,90 em āgua e 4,05 em KCl. No horizonte B O pH tan to em āgua como em KCl é, quando menos,iguar ao do ecossistema natural. 
Assim como no ecossistema natural, depois de 5 anos de cultivo os valores de $\mathrm{pH}$ dos diversos horizontes ē pouco variāvel e seu padrão, semelhante: decresce com a pro fundidade até certo ponto para tender a aumentar em seguida.

\subsection{Complexo de Troca Iônica}

Em relação ao pedon bem drenado do ecossistema natural o pedon desta fase possui mais bases trocáveis tanto no horizonte $A(2,04$ contra 1,27 emg/lo0g, médias ponderadas em função da espessura dos subhorizontes) quanto no horizonte B $(0,13 \pm 0,08$ contra $0,07 \pm 0,01 \mathrm{emg} / 100 \mathrm{~g}$, médias aritiméticas entre os subhorizontes atē a profundidade de $100 \mathrm{~cm})$. Jà em relação ao pedon moderadamente drenado embora o teor de bases seja maior no horizonte $A, \bar{e}$ menor no horizonte $B$.

Com o teor de $\mathrm{H}+\mathrm{Al}$ trocāveis ocorre o inverso no horizonte $A$ : no ecossistema natural, principalmente no pedon moderadamente drenado, os valores são maiores que no pe don da fase de 5 anos de cultivo $(1,29$ contra $0,27 \mathrm{emg} / 100 \mathrm{~g}, \mathrm{me}$ dias ponderadas em função da espessura dos subhorizontes até $100 \mathrm{~cm}$ de profundidade).

Em consequência, o valor $V$ é maior no horizonte $A$ do pedon desta fase $(91$ e $86 \%$ respectivamente aos hori zontes $A_{1}$ e $A_{3}$ ) que no pedon bem $(86,50$ a $21 \%$ respedtivamente aos horizontes $A_{11}, A_{12}$ e $A_{3}$ ) e moderadamente drenado (68, 28 e $13 \%$ respectivamente aos horizontes $A_{11}, A_{12}$ e $A_{3}$ ) do e cossistema natural. No horizonte $B$ os valores de $V$ são mais 
elevados que no pedon bem drenado que the serve de padrão contra $3 \%$, média aritimética até $100 \mathrm{~cm}$ ) porém são menores que no pedon moderadamente drenado $(17 \%)$.

\subsection{Densidade e Porosidade}

A densidade de partīculas é cerca de $0,70 \mathrm{~g} / \mathrm{cm}^{3}$ mais baixa que no pedon moderadamente drenado e fica, em termos médios $\left(2,75 \pm 0,02 \mathrm{~g} / \mathrm{cm}^{3}\right)$, em posição intermediāria entre os pedons das duas outras classes de drenagem do ecossistema natural.

Quanto a densidade do solo, tanto o horizonte $A$ quanto o horizonte $B$ possuem valores consideravelmente mais $\underline{e}$ levados que os do ecossistema natural. No horizonte $A_{1} \bar{e} 1,58$ $\mathrm{g} / \mathrm{cm}^{3}$, do horizonte $A_{3}$ ao $B_{12}(32-45 \mathrm{~cm})$ permanece em $1,74 \mathrm{~g} / \mathrm{cm}^{3}$, diminuindo para $1,65 \mathrm{~g} / \mathrm{cm}^{3}$ nos horizontes $B_{13}(45-70 \mathrm{~cm}), B_{21}$ (70$95 \mathrm{~cm})$ e $B_{22}\left(95-100^{+} \mathrm{cm}\right)$. No ecossistema natural a densidade glo bal no horizonte $A_{1} \bar{e}$ sempre inferior a $1,54 \mathrm{~g} / \mathrm{cm}^{3}$ e no horizonte $B$ a $1,65 \mathrm{~g} / \mathrm{cm}^{3}$.

A porosidade total e $0,42 \mathrm{~cm}^{3} / \mathrm{cm}^{3}$ no horizonte $A_{1}$ e varia em torno de $0,39 \pm 0,02 \mathrm{~cm}^{3} / \mathrm{cm}^{3}$ nos demais horizon tes. Portanto, os valores de poroṣidade do solo são menores que os do ecossistema natural onde os valores são superioresa $0,46 \mathrm{~g} / \mathrm{cm}^{3}$ no horizonte $A_{1}$ e estão em torno de $0,44 \pm 0,02 \mathrm{~cm}^{3}$ / $\mathrm{cm}^{3}$ considerando-se a profundidade de $100 \mathrm{~cm}$. 
4.2.2.4. Pousio de 3 Anos após 2 Anos de Culti vo

Com o pousio de 3 anos após o solo haver sido cultivado durante 2 anos, as caracteristicas do solo tendem a retornar às condições originais.

\subsection{Carbono e Nitrogēnio}

Nesta fase a quantidade de C armazenada ate 100 $\mathrm{cm} \bar{e}$ de $6,50 \mathrm{~kg} / \mathrm{cm}^{2}$, idêntica a do ecossistema natural, especí almente a do pedon bem drenado $\left(6,58 \mathrm{~kg} / \mathrm{m}^{2}\right)$. Contudo, observase que hā variações na distribuição desse elemento: na faixa de $10-50 \mathrm{~cm}$ a quantidade é mais elevada sob pousio, havendo uma compensação nas faixas de $0-10$ e $50-100 \mathrm{~cm}$, onde a quantidade é maior no ecossistema natural (Tabela.14, pägina 142).

A quantidade de $\mathrm{N}$ a rmazenado é $0,59 \mathrm{~kg} / \mathrm{m}^{2}$, menor que no pedon bem drenado $\left(0,65 \mathrm{~kg} / \mathrm{m}^{2}\right)$ e ligeiramente maior que a do pedon moderadamente drenado do ecossistema natura?.

A relação $C / N$ é máior que no ecossistema natural (pedon bem drenado), tanto na superficie como em profund $\underline{i}$ dade. No horizonte $A_{11} \bar{e} .12,3$ e no $A_{12}$, 11,2, enquanto no ecossistema natural (pedon moderadamente drenado) os valores correspondentes são 11,9 e 10,1. A partir do horizonte $A_{3}$ os valores oscilam em torno de $11,1 \pm 1,32$, enquanto na profundidade correspondente do ecossistema natural (pedon bem drena do) estão em torno de $9,9 \pm 0,9$. 


$$
4.2 .2 .4 .2 . \mathrm{pH}
$$

Os valores de pH são mais elevados que os do e cossistema natural até o horizonte $A_{3}$, tanto em àgua como em $K C l$. No horizonte $B$ os valores de $\mathrm{pH}$ são maiores do que os do pedon bem drenado, porém, se equivalem aos dos pedons imper feitamente e moderadamente drenado.

os valores de pH são mais negativos que no pe don bem drenado, embora em ambos sejam pouco variāveis,ao con trārio do que ocorre nos outros dois pedons do ecossistema na tural onde os valores são mais variāveis e notadamente meno res a altura dos horizontes $\mathrm{A}_{12}$ e $\mathrm{A}_{3}$.

\subsection{Complexo de Troca Iönica}

0 teor de bases, embora decresça progressiva.mente ao longo do perfil, é maior a partir do horizonte . A 12 que no pedon bem drenado, e se equivale no horizonte $B$ ao pedon moderadamente drenado.

0 teor de $H+A l$ é menor, tanto no horizonte $A$ como no horizonte $B$, que no pedon bem drenado e se equivale ao pedon moderadamente drenado apenas no horizonte $B$.

Em conseqüência os valores de $V$ tambēm são mais elevados que os do pedon bem drenado e idênticos aos do ho rizonte $B$ do pedon moderadamente drenado.

Em comparação ao pedon moderadamente drenado,o valor $T$ permanece mais elevado no horizonte $A$, embora tambëm 
não haja diferença no horizonte B.

o valor $V$, não obstante maior no horizonte. A que no ecossistema natural, é menor que o encontrado depois de 5 anos de cultivo. Jā no horizonte $B$ o valor $V \bar{e}$ idēntico ao do ecossistema natural, porém mais elevado que no solo cultivado por 5 anos.

\subsection{Densidade e Porosidade}

A densidade de partīculas esté em torno de $2,70 \pm 0,06 \mathrm{~g} / \mathrm{cm}^{3}$ ate 0 horizonte $A_{3}$, aumenta nos dois horizontes seguintes $\left(B_{11}\right.$ e $B_{12}$ ) para 2,89 e $2,97 \mathrm{~g} / \mathrm{cm}^{3}$, respectiva mente, e diminui nos demais horizontes para cerca de $2,82 \pm 0,02$ $\mathrm{g} / \mathrm{cm}^{3}$. Em relação ao pedon bem drenado estes valores são $i$ dēnticos na superfície $(0-20 \mathrm{~cm})$ e na faixa de $40-100 \mathrm{~cm}$, sendo mais elevados na faixa de $20-40 \mathrm{~cm}\left(2,93\right.$ contra $\left.2,76 \mathrm{~g} / \mathrm{cm}^{3}\right)$. Em comparação ao pedon moderadamente drenado são encontradas es tas mesmas diferenças até $70 \mathrm{~cm}$. A partir da $\bar{i}$ os valores de den sidade de partĩculas nesta fase são menores $(2,81$ contra 2,23 $\left.\mathrm{g} / \mathrm{cm}^{3}\right)$.

A densidade do solo é em geral semelhante a dos pedons bem e moderadamente drenados nos horizontes $A_{11}$, $A_{12}$ e $A_{3}$, e é ligeiramente menor no horizonte $B$, a excessão da faixa $20-40 \mathrm{~cm}$ onde é semelhante.

Quanto a porosidade, apresenta-se com valores semelhantes aos do pedon bem drenado nos horizontes $A_{12}$ e $A_{3}$ e aos do pedon moderadamente drenado nos horizontes $A_{11}$ e 
$A_{3}$. Em ambos os pedons a porosidade no horizonte B é ligeira mente menor que no solo em pousio.

4.3. Consequências da Alteração do Ecossistema

A seguir serão discutidas as alterações que $\underline{0}$ correm no ecossistema na sequência queimada-cultivo-pousio, com base nos resultados apresentados nos itens 4.1 e 4.2 . deste capitulo.

Serão abordadas as mudanças na vege tação, nos residuos vegetais depositados na superficie e, por fim, as modificações ocorridas no solo, incluindo as altera ções micromorfológicas.

\subsubsection{Mudanças na Vegetação}

O corte e a queimada da vegetação é feito com o objetivo de preparar o solo para o cultivo. Com estas opera ções se elimina completamente a vegetação primāria.

Depo is da queimada recomeça novo ciclo silvoge nētico atravēs da instalação de espécies heliófilas (FLORES TA, 1982).

Com o cultivo, as permanentes capinas impedem que as espécies pioneiras se instalem. Posteriormente, quando a ārea de cultivo é abandonada se instala uma vegetação secun dāria onde é marcante a participação do gênero Cecropia no es trato arbōreo, e das gramineas no estrato arbustivo, causando uma elevada densidade de espécies, ao contrārio da vegetação 
primāria que se caracteriza por elevada diversidade (DANTAS et alii, 1980).

Apōs vārios anos de cultivo a vegetação que se instala inicialmente é de natureza herbācea, constituida principalmente de espēcies das famīlias Gramineae e Compositae. Pos teriormente se formam nūcleos esparsos de Cecropia sp.

Caso não se prolongue o cultivo por muitos anos, hā a regeneração da vegetação embora de forma muito mais lenta que se o solo não houvesse sido cultivado (LESCURE, 1978 ; PREVOST, 198Tb).

$\mathrm{Na}$ regeneração da vegetação das āreas cultiva das as espēcies do gēnero Cecropia assumem papel muito impor tante.

$\mathrm{Na}$ ārea em pousio de 3 anos onde o solo havia sido cultivado durante 2 anos, a vegetação secundāria se constituia de 4 estratos.

0 primeiro estrato, constituido de Cecropia $s p$, era formado por nūcleos dispersos de 4 a 6 ärvores com 12 a $15 \mathrm{~m}$ de altura, cobrindo $40 \%$ da superficie.

0 segundo estrato, bastante heterogēneo, era for mado por ārvores de 5 a $10 \mathrm{~m}$ de altura e correspondia a $30 \%$ da superfície.

0 terceiro estrato era formado de arbustos que se reuniam em touceiras de 1 a $2 m$ de altura.

0 quarto e ūitimo estrato, praticamente de natu reza herbācea, era formado principalmente de gramíneas com o corrēncia de algumas espécies arböreas ainda nos estāgios ini- 
ciais de desenvolvimento. Este estrato era exclusivo em rela ção ao terceiro, correspondia a $40 \%$ da superficie e ocorria na forma de nūcleos dispersos com 2 a 3 metros de raio.

\subsubsection{Mudanças nos. Residuos Vegetais sobre o Solo}

Neste item serão discutidos os efeitos da queimada, do cultivo e do pousio sobre os resíduos vegetais deposí tados sobre a superficie.

\subsubsection{Efeitos da Queimada}

A queimada altera substancialmente a quantidade de residuos vegetais que constituem a liteira. Esta alteração se dā atravēs da combustão de parte dos componentes da liteira e do aporte de resíduos da vegetação derrubada.

\subsection{Peso dos Resíduos}

Considerando-se os dados anteriormente apresentados (tabela 7) verifica-se que permanecem $10.407 \mathrm{~kg} / \mathrm{ha}$ (peso secol de resīduos, incluindo os galhos atē $6 \mathrm{~cm}$ de diāmetro. É te valor corresponde a um pouco mais da metade do peso total da liteira do ecossistema natural (tabela 1 ). 
4.3.2.1.2. Distribuição dos Componentes

Os fragmentos vegetais depois da queimada incluem parte da liteira que não sofreu combustão além de galhos e fragmentos provenientes das ārvores derrubadas. Estes ūitimos fragmentos são na maioria, carvão, cinzas e pedaços de ga lhos parcialmente queimados (tabela 7).

A produção de carvão e cinzas de uma queimada depende da fitomassa e da intensidade da prōrpia queimada. Es ta, por sua vez, varia, segundo DANTAS e MATOS (1981), em fun ção da derrubada, da secagem do material e da velocidade do vento.

Estes mesmos autores estimaram em aproximada mente $17.000 \mathrm{~kg} / \mathrm{ha}$ a quantidade de cinzas e carvão após a quei mada de uma ārea de floresta primāria. Este valor é bem maior que o encontrado no presente estudo se considerarmos como tal os $4.063 \mathrm{~kg} / \mathrm{ha}$ correspondentes a soma das quantidades de carvão e fragmentos indiferenciados. Esta diferença pode ser atribuida a intensidade da queimada.

Pela ação do fogo as folhas e as raizes vivas encontradas na liteira do ecossistema natural desaparecem enquanto a quantidade de galhos de diâmetro idêntico ao do ecos sistema natural $(<3 \mathrm{~cm}$ ) diminui e a de fragmentos aumenta (tabelas 1 e 7 ). 
A combustão da vagetação derrubada acarreta a perda por volatilização de considerável quantidade de C e outros elementos.

Depois da queimada é difícil se distinguir os residuos remanescentes da liteira dos que provem da vegetação derrubada. Por esse motivo não se pode realizar uma avaliação completa das perdas por volatilização.

Contudo, observando-se a distribuição por clas se de diâmetros dos galhos, os quais constituem a maior parte dos resíduos, é possivel se avaliar parcialmente as perdas por volatilização.

A Tabela. 13 contēm quantidade de carbono distribuída por classe de diāmetro dos galhos encontrados no ecos sistema natural e na ārea adjacente recém-queimada.

TABELA 13 - Quantidade de carbono distribuída por classe de diàmetro dos galhos existentes no ecossistema natural e na àrea recém-queimada.

\begin{tabular}{|c|c|c|c|}
\hline \multirow{2}{*}{$\begin{array}{l}\text { Diāmetro dos } \\
\text { galhos }(\mathrm{cm})\end{array}$} & \multicolumn{2}{|c|}{ Quantidade de C ( $\mathrm{kg} / \mathrm{ha})$} & \multirow{2}{*}{$\begin{array}{l}\text { Dife- } \\
\text { rença }\end{array}$} \\
\hline & Ecossist. Natural & Recém-queimado & \\
\hline$<1$ & 1.499 & 148 & 1.351 \\
\hline $1-3$ & 1.267 & 847 & 420 \\
\hline Galhos atē $3 \mathrm{~cm}$ & 2.766 & 995 & 1.771 \\
\hline $3-6$ & 0 & 1.029 & -1.029 \\
\hline Galhos até $6 \mathrm{~cm}$ & 2.766 & 2.024 & 742 \\
\hline
\end{tabular}


Atravēs do exame da Tabela 13 se deduz que ocor re a combustão de pelo menos $5.000 \mathrm{~kg} / \mathrm{ha}$ de liteira, ou seja, cerca de $64 \%$ da quantidade inicial dos galhos e $29 \%$ da 1 iteira. Em termos de carbono estima-se que no minimo $1.771 \mathrm{~kg} / \mathrm{ha}$ desse elemento contido na liteira foram volatilizados durante a queimada.

Na liteira do ecossistema natural praticamente não se encontram galhos com mais de $3 \mathrm{~cm}$ de diâmetro e a clas se que sofre maior combustão é a de galhos com menos de $1 \mathrm{~cm}$ de diâmetro.

Após a derrubada da vegetação, grande quantida de de galhos é depositada sobre a superfície e destes os que mais predominam após a combustão são os de mais de $3 \mathrm{~cm}$ de diâa metro.

Com a queima dos galhos e troncos pequenos que se costuma fazer após a queimada aumentam ainda mais as perdas por volatilização.

4.3.2.2. Efeitos do Cultivo e do Pousio

Depois da queimada os residuos existentes sobre o solo se decompoem com velocidade que depende das condições de umidade e temperatura.

\subsection{Peso dos Resíduos}

Com o cultivo a quantidade desses residuos diminui consideravelmente, podendo chegar a valores muito redu 
zidos depois de vārios anos de cultivo. Comparando-se os dados já apresentados a quantidade de resijduos que compõe a $1 i$ teira no ecossistema natural é em média $17.700 \mathrm{~kg} / \mathrm{ha}$ (Tabela 1) e diminui para 3.305 e $1.537 \mathrm{~kg} / \mathrm{ha}$ (Tabela 7), apös 1 e 5 anos de cultivo, respectivamente.

Por outro lado, o pousio possibilita a recuperação acelerada da litiera. Quando o solo foi cultivado por 2 anos e ficou em pousio por 3 anos a quantidade de residuos foi $13.428 \mathrm{~kg} / \mathrm{ha}$ (Tabela 7 ), o que corresponde a $76 \%$ da liteira do ecossistema natural. Resultado idéntico a este ūitimo foi encontrado Por TURENNE (1977) na Guiana Francesa, no al to rio 0iapoque, o que levou-o a concluir ser muito ativa a dinā mica de regeneração da vegetação durante o pousio.

\subsection{Distribuição dos Componen- tes}

Quanto a distribuição dos componentes dos residuos vegetais verifica-se que com o cultivo as folhas depositadas sobre o solo estão presentes apenas no período pós-có Theita na forma de restos culturais que se decompõem rapidamente.

A quantidade de galhos diminui com o cultivo, chegando praticamente a desaparecer depois de vārios anos de cultivo.

Os fragmentos diminuem acentuadamente apōs 1 a no de cultivo e tendem a se estabilizar posteriormente.

0 pousio faz aumentar. acentuadamente as quan - 
tidades de folhas, galhos e fragmentos. As folhas, principalmente, aumentam consideravelmente alcançando maior percentua? de participação no peso total dos residuos sob pousio em comparação a ecossistema natural ( $43 \%$ contra $38 \%$ ).

\subsection{Quantidade de Carbono e Ni trogênio}

A quantidade de C armazenada nos residuos vege tais da superficie também tende a diminuir com o cultivo em consequéência ao decrēscimo na quântidade de resĩduos.

Segundo os dados aqui apresentados a quantidade de $C$ armazenada nos resíduos vegetais depositados na super fície passa de $6.119 \mathrm{~kg} / \mathrm{ha}$ no ecossistema natural (tabela 1 ), para 1.089 e $503 \mathrm{~kg} / \mathrm{ha}$ após 7 e 5 anos de cultivo (tabela 7), respectivamente.

Contudo, sob pousio a quantidade de C armazena da tende a se recuperar, juntamente com o peso dos residuos. Depois de 3 anos de pousio, havendo o solo sido cultivado por 2 anos, a quantidade de C armazenada nos residuos vegetais é de $4.475 \mathrm{~kg} / \mathrm{ha}$ (tabela 7 ). Este valor corresponde a $73 \%$ da quan tidade existente na liteira do ecossistema natural (tabela 1). Considerando-se a quantidade de C armazenada no estrato herbāceo, o qual è de ciclagem bem mais rápida que o contido na vegetação do ecossistema natural, ter-se-ia que adicionar às quantidades jā referidas cerca de 3.000 e $120 \mathrm{~kg} /$ ha, respectivamente a solo cultivado por 5 anos e a solo sob pousio. 
A quantidade de $N$ armazenada tambēm acompanha - decréscimo da quantidade de residuos vegetais. Encontram-se armazenados nesses residuos $29,92 \mathrm{~kg} / \mathrm{ha}$ de $\mathbb{N}$ após 1 ano de cul tivo e $11,13 \mathrm{~kg} / \mathrm{ha}$ após 5 anos de cultivo. Sob pousio a quanti dade existente é de $127,08 \mathrm{~kg} / \mathrm{ha}$ de $\mathrm{N}$ o que corresponde a $73 \%$ da média encontrada no ecossistema natural.

A relação C/N dos resîduos depositados também sofre alterações com o cultivo e com o pousio. o valor calculado para a totalidade dos resīduos na fase recém queimado è 36 . A comparação com os valores encontrados nas demais fases do ecos sistema alterado está prejudicada pelo fato de não haver galhos da vegetação primāria em todos os locais de amostragem da quelas fases, o que reduz a representatividade da amostra e, consequentemente, das quantidades totais de C e N calculádas.

Por outro lado, a relação $C / N$ dos fragmentos que constituem parte dos residuos vegetais indicam variações nos teores de $\mathrm{C}$ e $\mathrm{N}$ desses componentes nas diversas fases de alte ração do ecossistema. Na fase recém-queimado, a relação C/N é mais baixa que a encontrada nos fragmentos da liteira no ecos sistema natural, devido ao menor teor de C. A relação $C / N$ aumenta após 1 ano de cultivo quando se encontra um maior teor de C. Na fase cultivado por 5 aros o teor de $C$ tende a se ele var e o de $\mathrm{N}$ a diminuir, aumentando a relação C/N para um valor bem mais elevado que o do ecossistema natural. Finalmen te, sob pousio a relação C/N diminui devido ao aumento no teor de $N$. 
0 menor teor de C enciontrado na fase recēm-quei mado se deve provavelmente a grande quantidade de cinzas conti das entre os fragmentos indiferenciados. O aumento no teor desse elemento nos fragmentos da fase cultivado por 1 ano pode ser atribuido ao desaparecimento das cinzas que são em parte incor poradas ao solo. Com efeito verifica-se um abaixamento sensi vel na quantidade de fragmentos indiferenciados nesta fase.

A diminuição do teor de $N$ nos fragmentos na fase cultivado por 5 anos pode ser atribuida a natureza desses fragmentos os quais são oriundos principalmente de folhas de gramineas, reconhecidamente menos ricas em $N$ Jà na fase de pousio o aporte e a decomposiçäo continua de fothas e ramos acarreta a ocorrência de fragmentos mais ricos em N.

\subsubsection{Mudanças no Solo}

Conforme foi abordado no item 4.2.2. as diver sas fases de alteração do ecossistema provocam mudanças importantes nas propriedades do solo. A seguir será traçada a sequência de eventos que caracterizam as mudanças do solo em con seqüència da alteração do ecossistema em estudo.

\subsubsection{Carbono e Nitrogēnio}

No ecossistema natural as quantidades de $\mathrm{C}$ e $\mathrm{N}$ são a tē $100 \mathrm{~cm}$ de profundidade, em média, respectivamente 6,57 
$\mathrm{kg} / \mathrm{m}^{2}$ e $0,63 \mathrm{~kg} / \mathrm{m}^{2}$ (tabela 10). A distribuiçäo destes elementos difere entre as trés classes de drenagem emconsequência das variações na adição de material orgānico, a qual varia inclusi ve dentro da mesma classe de drenagem conforme foi discutido no item 4.1 .1 .1 .

\subsection{Efeitos da Queimada}

Na Tabela 14 e na Figura 18 consta a distribui ção do C apōs a queimada, bem como nas demais fases do ecossis tema alterado, e nas tres classes de drenagem do ecossistema naturai.

TABELA 14 - Distribuição do carbono até $100 \mathrm{~cm}$ de profundidade do solo no ecossistema natural e no ecossistema al terado.

\begin{tabular}{|c|c|c|c|c|c|}
\hline & \multicolumn{4}{|c|}{ QUANTIDADE DE $\mathrm{C}\left(\mathrm{kg} / \mathrm{m}^{2}\right)$} & \multirow{2}{*}{ TOTAL } \\
\hline & $0-10 \mathrm{~cm}$ & $10-2 \mathrm{~cm}$ & $20-50 \mathrm{~cm}$ & $50-100 \mathrm{~cm}$ & \\
\hline \multicolumn{6}{|c|}{ ECOSSISTEMA NATURAL. } \\
\hline Imperfeitamente Drenado & 1,81 & 0,78 & 1,74 & 1,96 & 6,29 \\
\hline Moderadamente Drenado & 1,68 & 0,94 & 1,96 & 2,26 & 6,84 \\
\hline Bem Drenado & 1,99 & 1,02 & 1,74 & 1,83 & 6,58 \\
\hline Média & 1,83 & 0,91 & 1,81 & 2,02 & 6,57 \\
\hline \multicolumn{6}{|c|}{ ECOSSISTEMA ALTERADO } \\
\hline Recēm Queimado & 1,66 & 0,92 & 1,66 & 2,09 & 6,33 \\
\hline Cultivado por 1 Ano & 1,57 & 0,98 & 1,92 & 2,27 & 6,74 \\
\hline Cultivado por 5 Anos & 1,29 & 0,91 & 1,63 & 1,82 & 5,65 \\
\hline Pousio 3 Anos & 1,55 & 1,12 & 2,05 & 1,78 & 6,50 \\
\hline
\end{tabular}


Apōs a queimada a quantidade de C armazenada $\bar{e}$ de $6,33 \mathrm{~kg} / \mathrm{m}^{2}$ e, em comparação a e cossistema natural, atē $100 \mathrm{~cm}$, pode ser considerada idêntica pois não chega a diminuir $4 \%$. A distribuição desse elemento, contudo, apresenta-se diferente. Hā nesta fase menor quantidade armazenada na faixa de $0-20 \mathrm{~cm}$, a qual é em parte compensada por uma maior quantidade na faixa de $50-100 \mathrm{~cm}$.

A diferença encontrada na faixa de $50-100 \mathrm{~cm}$ não è tão grande e talvez possa ser explicada através das diferenças de textura, porosidade e drenagem. Jä a diferença verifica da de $0-20 \mathrm{~cm}$ è mais acentuada, especialmente na camada de 0-10 $\mathrm{cm}$, e pode ser explicada atravës de duas hipóteses: menor adição de C, devido a uma menor produção de liteira nos locais de amostragem ou decréscimo do teor de c apōs a queimada.

A primeira hipótese è apoiada na possibilidade de haver correlação positiva significativa entre o peso da liteira e a quantidade de C armazenada nos 10 primeiros centimetros do pedon bem drenado do ecossistema natural, o qual serve de padrão de comparação.

A segunda hipótese tem sido constatada tanto de forma pouco acentuada, sem significação estatîstica (FALESI et alii, 1980; EMBRAPA, 1981), como de forma acentuada, embora res trita aos primeiros centimetros do solo [Betsch et alii (1981) citados por TURENNE (1982)]. Este fato é plausīvel de ocorrer con siderando a mudança do microclima criada pela erradicação da vegetação (DINIZ e BASTOS, 1980; HOLFRAN et alii, 1982) a qual pode propiciar a rāpida oxidação do C mesmo considerando um 


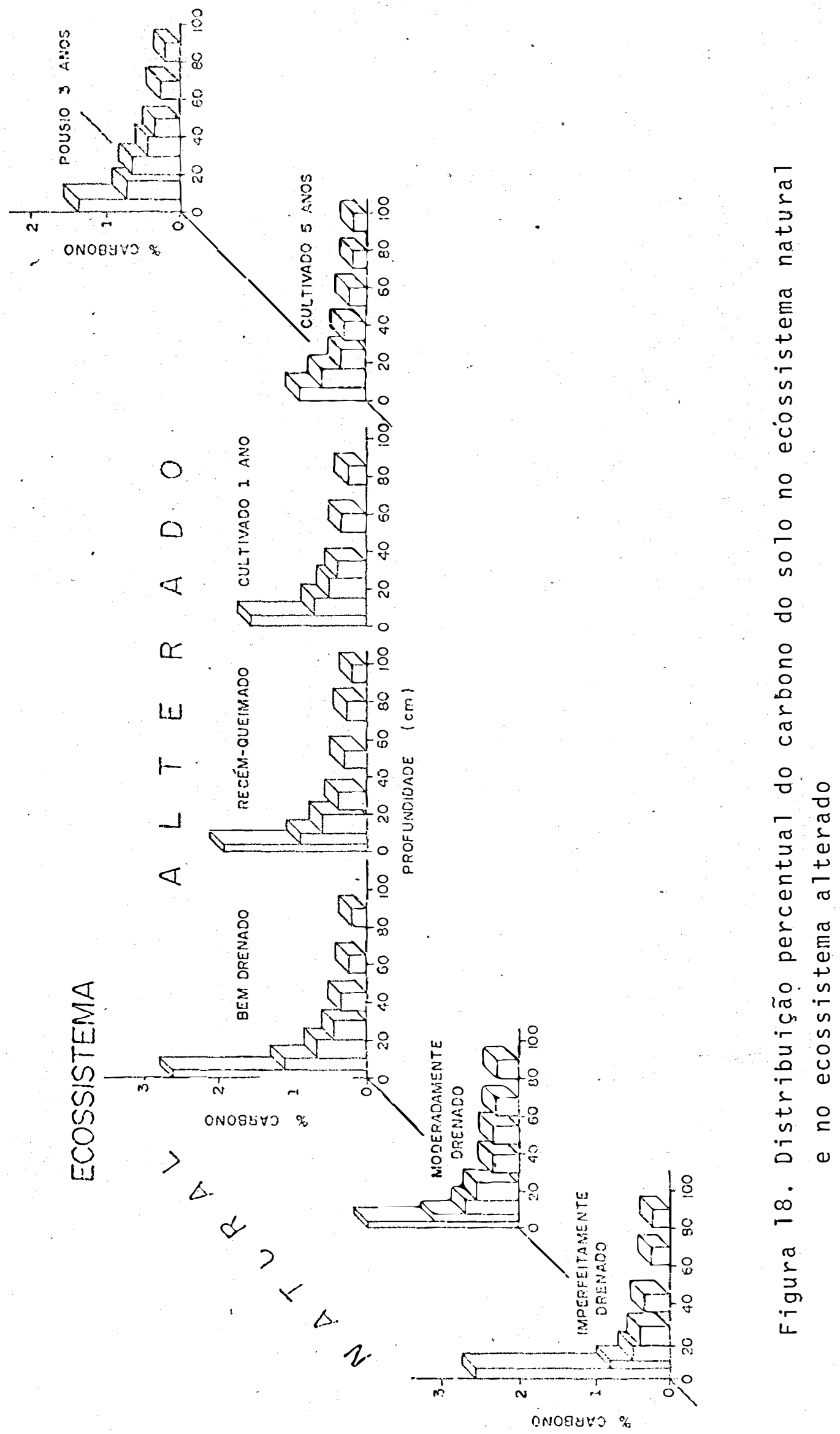


curto intervalo de tempo.

Por outro lado, è de se esperar que o teor de C aumente em decorrēncia da adição de fragmentos vegetais oriun dos da queimada (MILLER et alii, 1982). Isto, contudo, depende da intensidade da queimada.

4.3.3.1.2. Efeitos do Cultivo e do Pou sio

Depois de 1 ano de cultivo a quantidade de $C$ armazenada, embora seja menor na camada de $0-10 \mathrm{~cm}$, tende a au mentar em profundidade, especialmente de 50-100 cm, o que pode ser atribuida a maior migração de compostos orgânicos. Este fato alia-se a uma atividade biolōgica mais intensá apōs o des matamento (CHAUVEL, 1982) quando os animais passam a explorar maior volume do solo.

TURENNE (1977), ao contrārio, verificou que o teor de C no horizonte superficial é igual ou maior que o encontrado sob floresta, tanto no primeiro ano de cultivo quanto no segundo, sob pousio. Essa discordancia todavia pode estar ligada a diferenças decorrentes da quantidade de residuos existentes apōs a queimada, alēm das condições de oxidação li gados à textura, à drenagem do solo e suas interações com as mudanças microclimáticas.

Muito embora após 1 ano de cultivo a diminui ção da quantidade de C na superfície $(0-10 \mathrm{~cm})$ não seja maior que $14 \%$ e haja até uma tendéncia de aumentos quando se consin dera a profundidade de $-100 \mathrm{~cm}$, apōs vārios anos de cultivo pọ 
de haver decréscimos substanciais. Depois de 5 anos de culti vo a quantidade armazenada diminui em todo o perfil até $100 \mathrm{~cm}$ de profundidade cerca de $1 \mathrm{~kg} / \mathrm{m}^{2}$, u seja $14 \%$ menos que as quan tidades encontradas no ecossistema natural, sendo a redução mais pronunciada na superficie $(0-20 \mathrm{~cm})$.

Este fato se deve provavelmente ao favorecimen to da mineralização dos compostos orgãnicos em consequência da maior e majs prolongada exposição do solo à intempērie. CUNNIN GHAM (1963) verificou em Ghana, na Africa, que em parcelas to talmente expostas a intempérie ocorreu diminuição do C orgãni co e do $N$ total.

Os efeitos do pousio são marcantes. Segundo TU RENNE (1977), a liteira se reconstituiu no terceiro ano de pousio quando o solo foi cultivado por 1 ano. No caso deste estudo, em que o solo foi cultivado por 2 anos e ficou em pou sio por 3 anos a liteira correspondeu a $76 \%$ em peso da encontrada no ecossistema natural.

Portanto, è de se esperar que o pousio tenha forte influência na quantidade de C armazenada no solo,em con sequência da decomposição da grande quantidade de residuos ve getais que são depositados pelas espécies de rápido crescimento da vegetação secundāria.

Comparando-se a quantidade de C armazenada no solo sob pousio de 3 anos após 2 anos de cultivo com a encontrada no solo cultivado durante 5 anos verifica-se que há uma diferença de quase $1 \mathrm{~kg} / \mathrm{m}^{2}$. Esta diferença se justifica tânto pela diminuição do teor de C sob tempo prolongado de cultivo 
quanto pelo aumento sob pousio onde a quantidade de residuos sobre a superficie é muito elevada.

Em comparação ao ecossistema natural a diferen ça de C armazenada até $100 \mathrm{~cm}$ de profundidade não chega a ser maior que $5 \%$. Logo, se pode deduzir que hã diminuição acentua da no teor de C do solo entre o segundo e o quinto ano de cul tivo. Como no solo sob pousio de 3 anos após 2 anos de cultivo a quantidade desse elemento pouco difere da encontrada no ecossistema natural se pode firmar uma das duas premissas seguintes: o decréscimo não é acentuado no segundo ano de culti vo e o pousio de 3 anos poücocontribui para a elevação do teor de $C$; ou o decréscimo é muito acentuado no segundo ano e o pousio de 3 anos promove sua recuperação.

TURENNE (1977) verificou que depois de 2 anos de cultivo hä uma diminuição no teor de C no horizonte $A, \quad 0$ qual tende a se reconstituir com o pousio.

Com base no exposto, é razoāvel se aceite que tenha havido um decréscimo acentuado na quantidade de C duran te o segundo ano de cultivo.

Assim sendo, a quantidade de $C$ armazenada pode até ter aumentado durante o primeiro ano de cultivo as expensas da forte decomposição da grande quantidade de resíduos remanescentes da queimada e das raizes das antigas árvores, aliado a maior atividade biológica. Todavia, como as mudanças microclimäticas fá vorecem a acelerada mineralização dos compostos orgānicos e não hä suprimento em grande escalà de resíduos para serem decompostos, a quantidade de C sofre uma redução acentuada du - 
rante o segundo ano de cultivo e passa a diminuir menos nos anos seguintes, tendendo ao equilibrio posteriormente.

Se após o segundo ano o cultivo è interrompido pe 10 pousio, há uma recuperação muito lenta da quantidade de $C$ no primeiro ano, a qual tende a se acentuar no segundo e terceiro anos, de modo que apōs 3 anos jā é quase equiparável a do ecos sistema natural.

4.3.3.2. Complexo de Troca Iônica

As Figuras 19,20 e 21 contem, respectivamente, as variações dos valores referentes ao pH (em āgua), a capacidade de troca de cations e a saturação em bases na sequēncia floresta -queimada-cultivo-pousio.

No ecossistema natural as bases se concentram ao nĩvel do horizonte superficial $\left(A_{1}\right)$, onde a capacidade de troca de cátions é consideravelmente mais elevada que no restante do perfil. Isto ocorre devido ao alto teor de matéria orgánica en contrado na superfície o qual é, apesar da mineralização ser ele vada, constantemente suprido pela decomposição da liteira.

\subsubsection{Efeitos da Queimada}

Quando a vegetação é derrubada e queimada, grande quantidade de cinzas e resîduos vegetais é depositada na super fície. DANTAS e MATOS (1981) encontraram após a queimada, em um estudo realizado tambēm em Capitão Poço-Pa, uma quantidade mé.dia de $1.724 \mathrm{~kg} / \mathrm{m}^{2}$ de cinzas. Combase neste estudo, conside rando-se as quantidades dos elementos químicos extraídos das mes mas por dissolução em ãgua deionizada, estima-se que 
são adicionadas por $\mathrm{m}^{2}$, apōs as primeiras chuvas, $0,79 \mathrm{~g}$ de $\mathrm{Ca}_{3}$ $0,45 \mathrm{~g}$ de $M g$ e $38,38 \mathrm{~g}$ de $K$.

Como a vegetação é responsável pera intercepção de $20 \%$ do total da precipitação pluviométrica (WOLFRAN et alii, 1982), apōs o desmatamento tende a aumenta a quantidade de àgua que infiltra no solo. Nestas condições as bases liberadas das cinzas são trarsilocadas modificando em curto intervalo de tem po o pH e o complexo de troca iönica do solo. Dependendo das condições de drenagem do solo as bases podem até serem lixivi adas. A lixiviação deve ser mĩnima ou mesmo inexistente nos pedons imperfeitamente drenados. Em contrapartida devem ser pelo menos razoáveis nos pedons bem drenados.

As bases ao se transiocarem modificam o pH do perfil, especialmente nos horizontes superficiais. 0 complexo de troca ionica se altera injcialmente apenas ra superficie (ho rizonte $A_{17}$ ) onde ocorre um pequeno aumento do valor $T$ devido a liberação de cargas dependentes do $\mathrm{pH}$.

$0 \mathrm{pH}$ se eleva em pelo menos 2,5 unidades nos dez primeiros centimetros acarretando um aumento nesta camada de cerca de $1,5 \mathrm{emg} / \mathrm{l} 00 \mathrm{~g}$ nas cargas dependentes. 0 aumento das bases no complexo se dā na ordem $\mathrm{Ca}>\mathrm{Mg}>\mathrm{K}>\mathrm{Na}$ e as mesmas são responsāveis pela eliminação de pelo menos 0,5 emg/ioog de $\mathrm{H}+$ Al trocāveis do complexo. Em conséquência hä um aumento no va lor $V$ em torno de 2,5 vezes. 
4.3.3.2.2. Efeitos do Cultivo do Pou sio

No primeiro ano de cultivo as bases, liberadas das cinzas da queimada, mais concentradas no horizonte superfi cial, translocam para os horizontes subjacentes alterando o so 10 em maior profundidade.

$0 \mathrm{pH}$, embora mais elevado que no ecossistema na tural, apresenta-se menor na superfīcie que o encontrado apōs a queimada devido a troca das bases da solução com o H e O A. adsorvidos pelo complexo coloidal.

o teor de bases trocāveis permanece pelo menos lemg/loog mais elevado no horizonte $A$, em relação ao ecossiste ma natural, e aumenta pouco no horizonte $B(0,36 \mathrm{emg} / 100 \mathrm{~g})$. 0 teor de $H+A l$, ao conträrio, diminui em todo o perfil, especi almente no horizonte $A_{12}$, elevando o valor $V$.

No decorrer do primeiro ano de cultivo parece ha ver nos pedons imperfeitamente e moderadamente drenados apenas translocação das bases. O valor $T$ tende a diminuir na superficie (horizonte $A_{11}$ ), embora permanecendo em niveis superi ores ao do ecossistema natural, e a aumentar em profundidade. No horizonte $A_{11}$, não obstante a diminuição do valor $T$, ocorre maior substituição do $H+A l$ trocáveis, o que é facilitado pela ausência da acidez provocada pela decomposição da liteira, a qual acarretaria tambēm diminuição do pH. Em profundidade (ho rizonte $A_{12}$ em diante) o aumento do valor $T \bar{e}$ decorrente das bases presentes no complexo, antes mais concentradas na super- 
ficie, as quais passam a ocupar cargas dependentes liberadas em consequéncia do aumento do $\mathrm{pH}$.

Deve-se esperar que mudanças idēnticas ocorram na classe de solo bem drenado, porem, em maior velocidade, podendo haver perda de bases do perfil e diminuição de pH, inclu sive atingindo maiores profundidades.

Nos cultivos subsequentes, mesmo sob condições de boa drenagem não ocorrem mudanças muitos intensas no comple xo de troca. Embora com uma tendēncia de diminuição no valor $S$ e de aumento no teor de $H+A l$, depois de 5 anos de cultivo o valor $T$ do horizonte $A$, a exceção dos primeiros centimetros superficiais, per manece maior que a do ecossistema natural. Em consequência, o valor $v \bar{e}$, no horizonte A, maior que no ecossistema natural, porém semelhante ao de após 1 ano de cultivo.

A causa de manutenção no horizonte $A$ do valor $S$ e do teor de $H+A l$ em níveis mais adequados que os do ecossis tema natural mesmo depois de 5 anos de cultivo pode ser atribu ido a permanência dos efeitos da queimada jā que o teor de $c$ não justifica uma maior adição de bases em decorrēncia de de composição da matēria orgānica.

Por outro lado, no horizonte B hā lixiviação das bases em magnitude idêntica a da translocação havida no primeiro ano,acarre tando a ocorrência de valores idênticos aos do ecossistema natural.

Sabe-se que o pousio da terra propicia a regeneração dá vegetação, acarretando depois de muitos anos,o restabelecimento das condições originaịs do solo. Segundo MANARINo et alij (1982) as diferenças entre o solo de floresta primäria e 


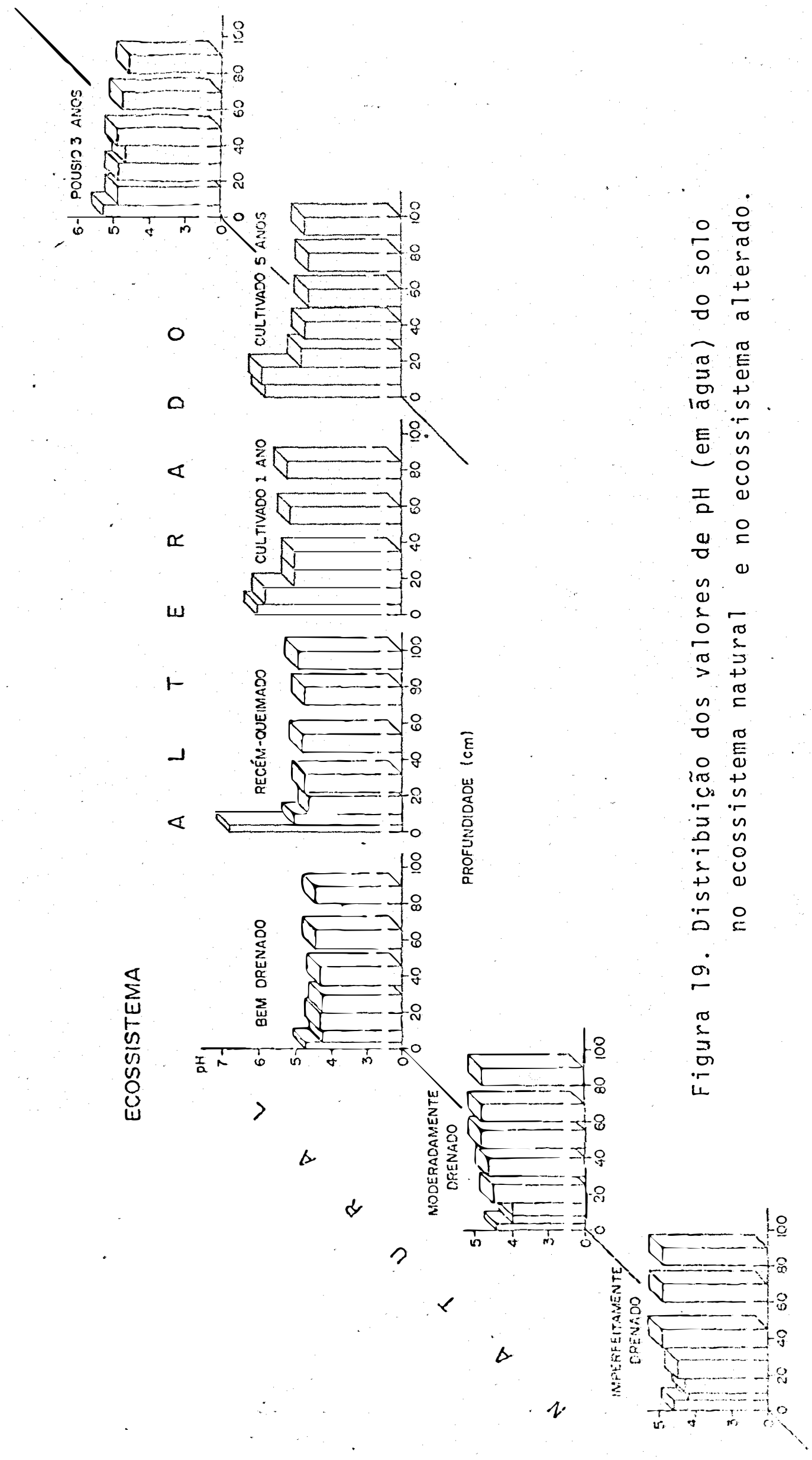




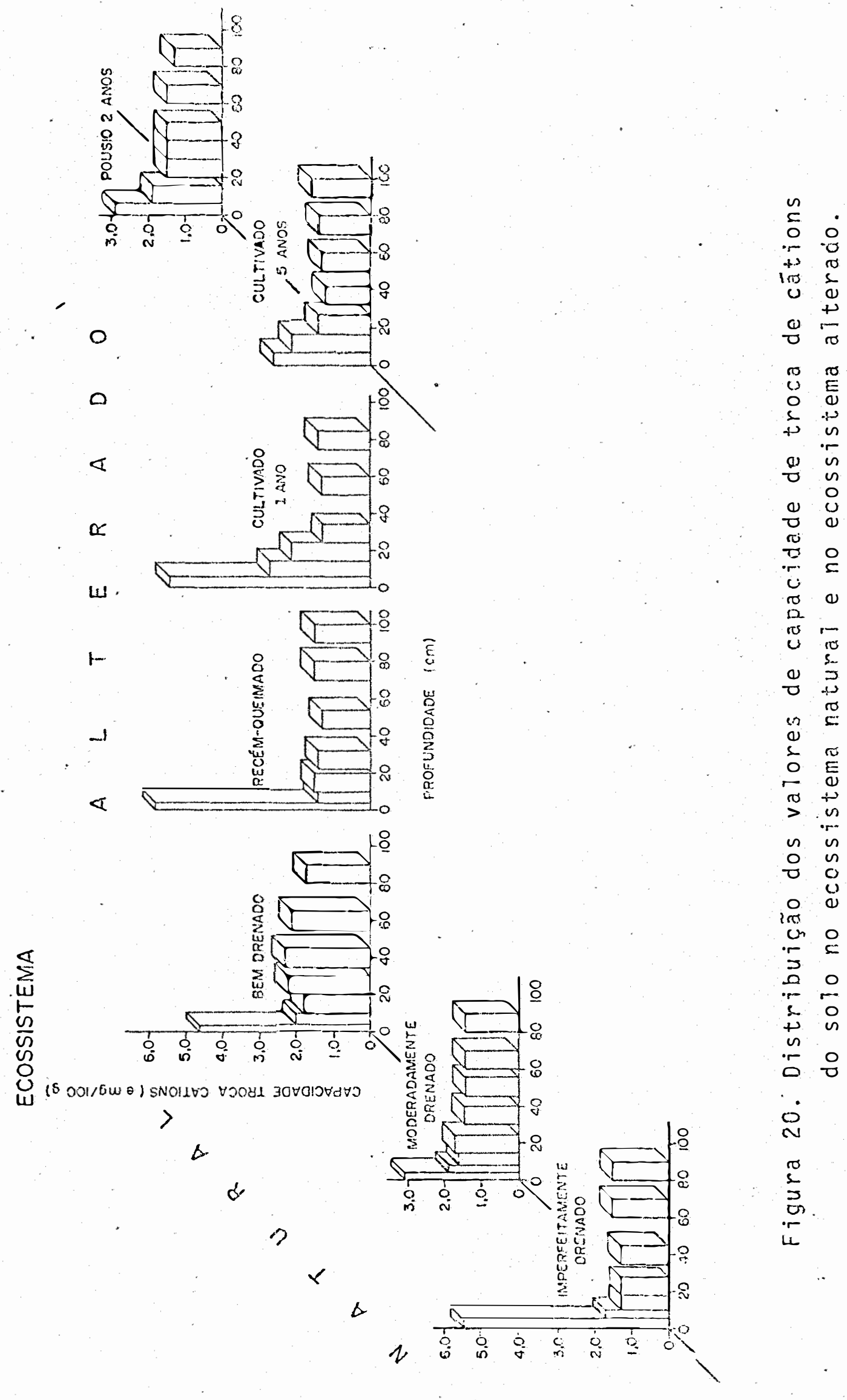




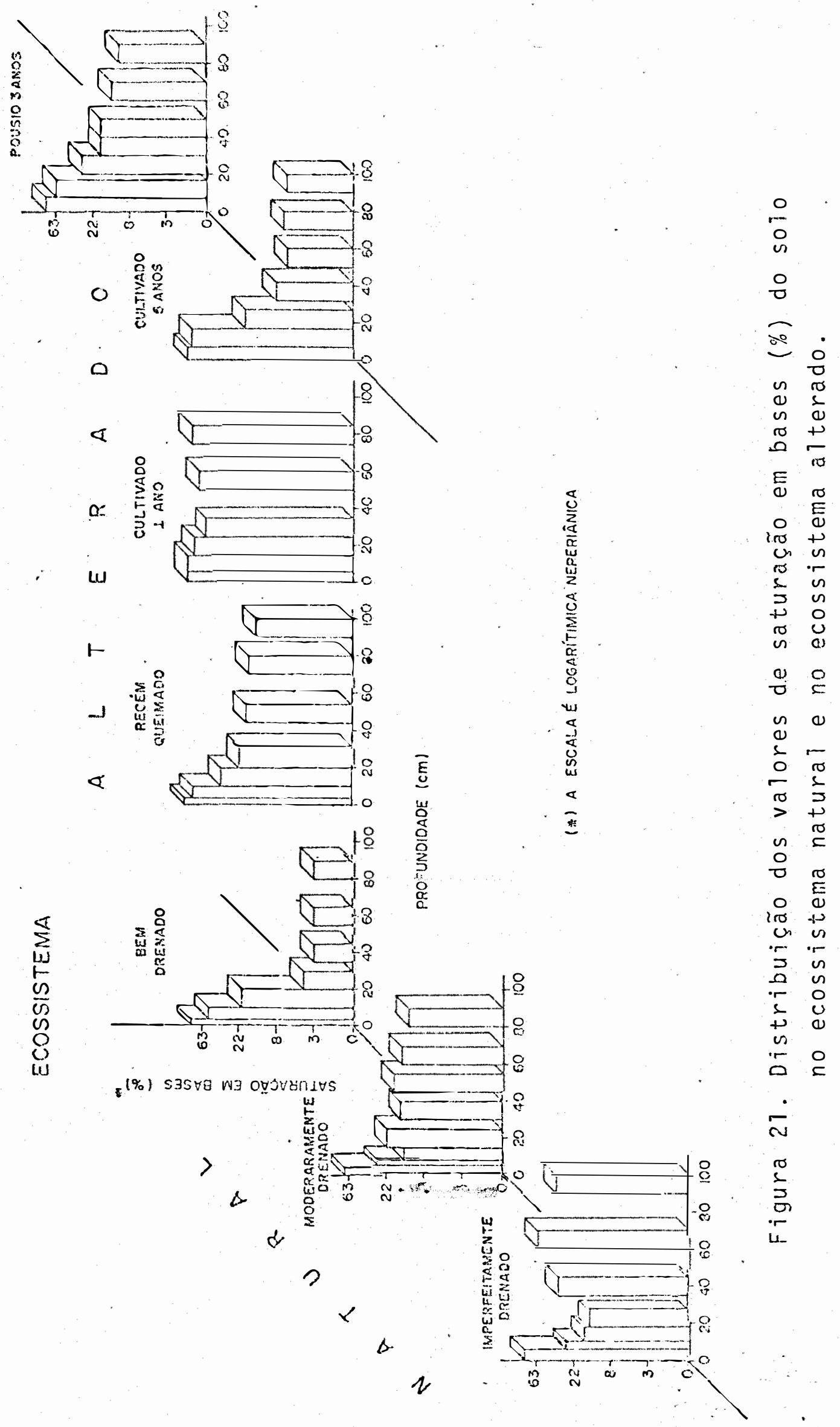


- solo sob pousio desaparecem se este for mantido por longos periodos.

Sob pousio de curta duração após pouco anos de cultivo é de se esperar que as modificações do solo sejam ainda menores que as encontradas no solo que ao invés de entrarem pousio continua sendo cultivado. Com efeito, sob pousio de 3 anos após 2 anos de cultivo o valor $T$ é ligeiramente maior, no horizonte $A_{7}$, que a do solo cultivado por 5 anos, embora no ho rizonte $\mathrm{A}_{3}$ ocorra o inverso e no horizonte $B$ não haja diferença.

o valor $V$ é menor no horizonte $A$ e maior no horizonte $B$ que o encontrado no solo que permaneceu sob cultivo. A diferença no horizonte A pode ser atribuida a acidez provoca da pela decomposição da liteira que mesmo sob pousio de apenas 3 anos atinge um peso correspondente a $76 \%$ do encontrado na $1 \underline{i}$ teira do ecossistema natural. No horizonte $B$, jā que não hā mo dificações no valor $T$ o aumento ocorrido no valor $V$ deve-se pro vavelmente a menor lixiviação das bases adicionadas consideran do-se que a vegetação secundāria, a esta altura com um porte considerāvel, deve impedir a infiltração de parte da āgua da chuva protegendo o solo contra a lixiviação.

\subsubsection{Densidade e Porosidade}

As transformações estruturais do solo em consequência do desmatamento e do cultivo são de grande importāncia. Segundo CHAUVEL (1982), as mudanças mais importantes dizem respeito à porosidade. 
Na sequéncia de alteracão do ecossistema estudado

variações tambëm se refletem na porosidade total e especialmente na den.sidade do solo. A Figura 22 mostra a variação dos valores de densidade do solo nas condições naturàis e apōs a alteração do ecossistema.

\subsection{Efeitos da Queimada}

0 pedon representativo desta fase, em comparäção ao seu correspondente no ecossistema natural, apresenta valores de densidade do solo maiores, a exceção do horizonie $A_{12}$ onde os valores são idēnticos, e de densidade de partículas idén ticos. Em consequéncia, os valores de porosidade são menores no pedon da fase recém-queimado.

Dois fatos podem explicar a ocorréncia de valores de densidade do solo maiores no pedon desta fase: a ocorrên cia de valores de densidade originatmente maiores n'aquela ärea e a migrạção de partículas finas em consequência do desmatamento.

Do mesmo modo que é possível se aceitar que ocor ram aumentos na densidade apōs o desmatamento, devido a falta de proteção do solo contra o impacto da chuva (HUDSON, 1971), tambëm o é que, em curto intervalo de tempo, sob condições de precipitações reduzidas (não chegou a chover $25 \mathrm{~mm}$ no intervalo en tre o desmatamento e a coleta de amostras), as alterações não chegariam a ser importantes. Com efeito, o grau de floculação do horizonte A nesta fase não mudou em relação ao padräo.

Assim, é plausível se aceite a primeira hipótese para justificar as diferenças encontradas no horizonte $B$, e a segunda para a encontrada no horizonte $A_{11}$, ja que no $A_{1}$. praticamente não houve dịferença. 


\subsection{Efeitos do Cultivo e do Pousio}

Durante o cultivo o solo permanece desprotegido e as mudanças microclimáticas que ocorrem tendem a acelerar os procesos de modificação tais como a migração de compostos or ganicos (MANARINO et alii, 1982), lixiviação das bases e trans locação de partículas finas (ROOSE, 1979).

Após o primeiro ano de cultivo, além do horizonte $A_{11}$, o horizonte $A_{12}$ tımbém é afetado, causando aumento na densidade do solo. O valor médio da densidade do solo do horizonte $A_{1}$ - obtido através de média ponderada em função da espes sura dos subhorizontes - que era de $1,21 \mathrm{~g} / \mathrm{cm}^{3}$ no ecossistema natural aumenta para $1,45 \mathrm{~g} / \mathrm{cm}^{3}$. Este fato está relacionado com a dispersão no horizonte $A$ pois enquanto a quantidade de particulas finas é menor, o grau de floculação é menor.

Por outro lado, a porosidade diminui apenas

na parte superior do horizonte $A_{11}$ e no horizonte B não há efeito restritivo na porosidade que chega até a aumentar na faixa de 35-100cm provavelmente em consequéncia de uma atividade biológ ca que explora mais profundamente o solo (MANARINO et alii, 1982). Todavia, depois de 5 anos de cultivo as restrições na densidade do solo e na porosidade chegam a afetar drāsticamente até o horizonte $B$. No horizonte $A_{j}$, onde os efe tos são mais acentuados, hā um aumento na densidade cio solo de $0,33 \mathrm{~g} / \mathrm{cm}^{3}$, em relação ao ecossistema natural, e de $0,12 \mathrm{~g} / \mathrm{cm}^{3}$, em relação a fase de 1 ano de cultivo. Quanto ao grau de flocula ção no horizonte $A$, observa-se que diminui sensivelmente. Em 
consequência hā uma diminuiçào ainda maior na porosidade

$q u \in$ passa para $42 \%$. No horizonte $A_{3}$ a densidade do solo é $0,18 \mathrm{~g} / \mathrm{am}^{3}$ maior que no ecossistema naturai, e no horizonte $B, 0,14 \mathrm{~g} / \mathrm{cm}^{3}$. A porosidade entäo diminui $7 \%$ no horizonte $A_{3}$ e $6 \%$ no B.

Como a ciensidade do solo e a porosidade são fortemente influenciadas peio teor de matéria organica, com o pousio, por haver recuperaçäo da quantidade de c armazenadā, a densidade do solo tende a diminuir e a porosidade a aumentar.

Pode-se avaliar a interrupção dos efeitos preju diciais do cultivo prolongado através dos dados da fase de pousio de 3 anos após. 2 anos de cultivo. Nestá fase observa - se que os valores de densidade diminuem ao mesmo tempo que o grau de floculação aumenta. A porosidade dos horizontes $A_{11}$ e $A_{12}$ se aproxima muito da encontrada no ecossistema natural e a poro sidade média do horizonte $A_{j} \bar{e} 50 \%$. No horizonte $A_{3}$ a porosida de é de 43\%, também idēntica a do ecossistema natural, e no horizonte B corresponde a uma mëdia de $47 \%$, nitidamente superior a do ecossistema natural.

A ocorrência de valores de porosidade mais elevados no horizonte $B$ na fase de pousio em comparação aos valores encontrados no ecossistema natural podem ser explicados através da intensa atividade biológica tambëm existente neste horizonte. CHAUVEL (1982) também verificou a ocorrēncia de in tensa atividade biolögica afetando a porosidade do solo sob pousio na Região de Manaus embora com influéncia somente nos horizontes $A_{1}$ e $A_{3}$. 


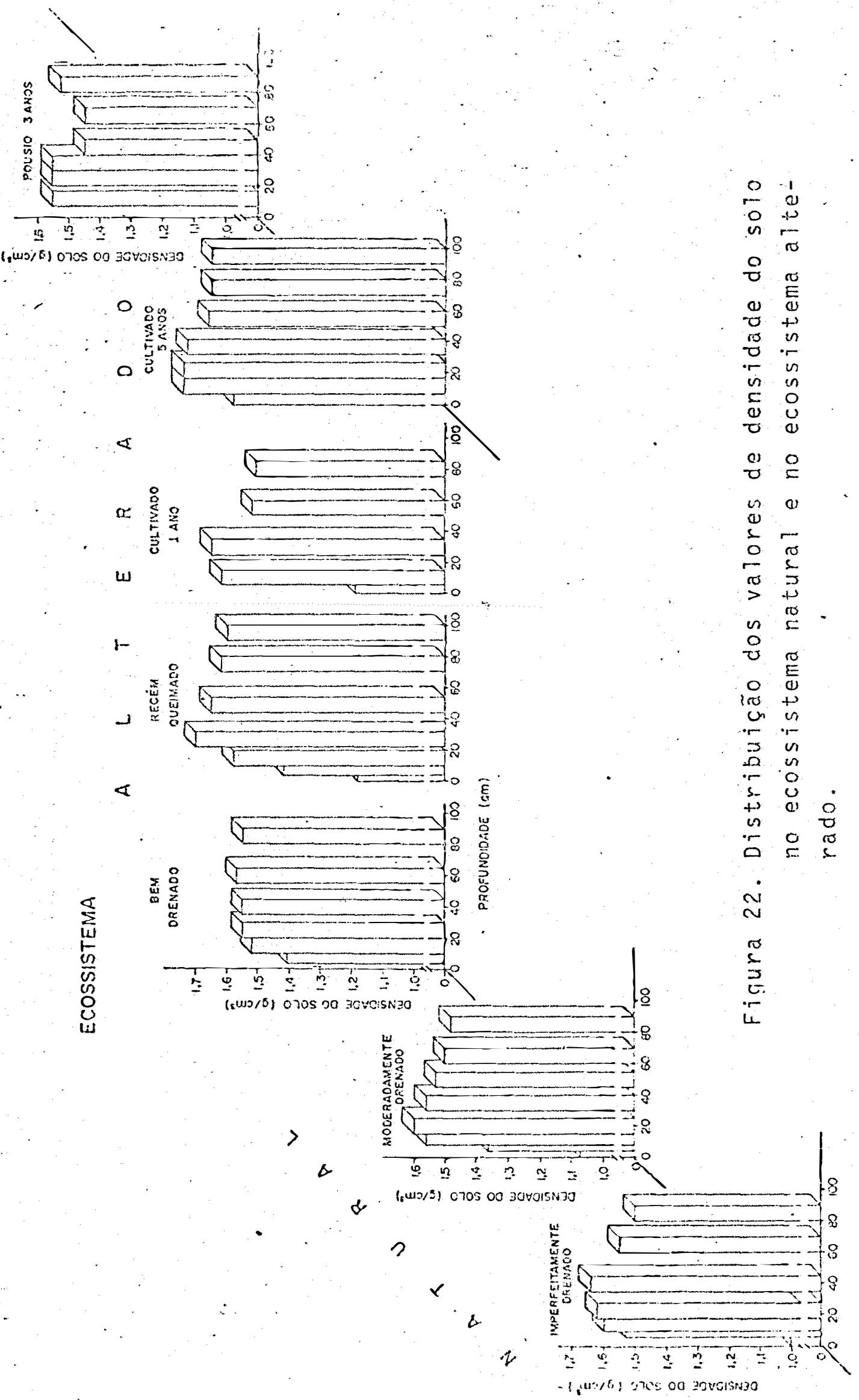




\subsubsection{Micromorfoiogia}

As variações do solo podem ser observadas com mais detalhes atraves do estudo micromorfolögico o qual permite, in clusive, explicar mudanças ocorridas em algumas das caracteristi cas físicas e químicas.

\subsection{Area Cultivada por I Ano}

O horizonte $A_{12}$ do sole após 1 ano de cultivo pos sui um plasma bruno amarelado com fortes variações na cor e se apresenta em mássa continua que tende a segregar-se do esqueleto originando um padrão de distribuição tipicamente agrupado (Figu ra 23$)$.

No horizonte $A_{3}$ embora persistam setores exibindo a microagregação original do ecossistema natura 1 , constata-se que em geral o plasma estā pouco agregado e que ocorrem pequenos cu tans de argila bruno amarelo claro evidenciando uma redistribui ção do plasma (Figura 24).

No horizonte B ocorrem dois fundos matriciais dis tintos : um de coloração bruno acinzentado, onde o esqueleto ë relativamente abundante e aparecem microagregados e residuos ve getais; outro de cor bruno mais claro, com dominância do plasma que forma uma massa continua, envolve o esqueleto pouco abundante, apresenta macroporosidade reduzida e possui cutans de argila nos limites dos vazios que são predominantemente do tipo fissu ral (Figura 25). Há,portanto, justaposição no perfil, ao nível do horizonte $B$, de partes que apresentam caracteristicas físicas diferentes. 


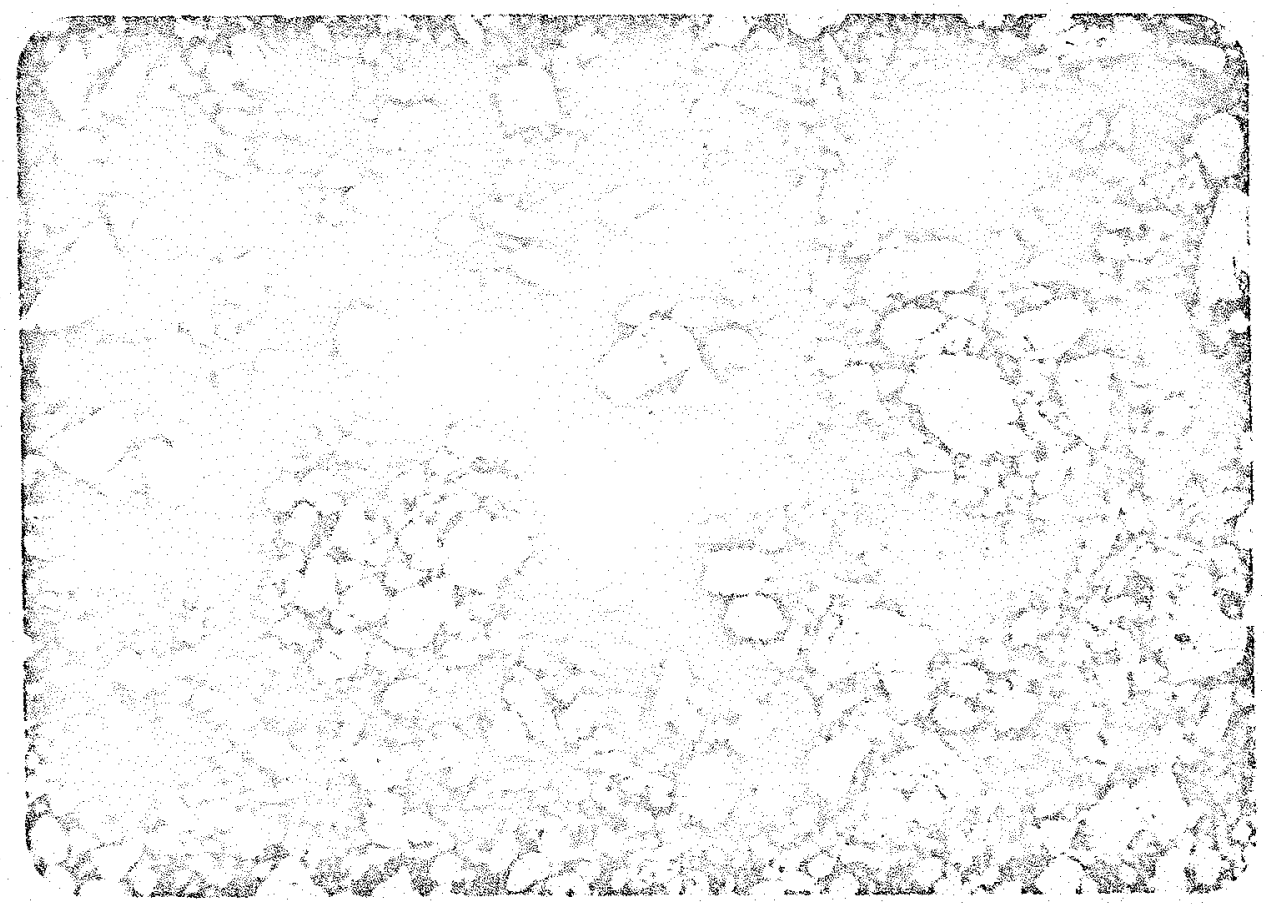

Figura 23 - Fotomicrografia $(12 X)$ relativa ao horizonte $A 12(6-15 \mathrm{~cm})$ do so 10 na ärea Cultivada por 1 ano: Aspecto do plasmà bruno distri buî̉o em una mâssa continua ein consequlencia dos efeitos do des matamento apōs 1 ano de cultivo, acentuando o padrão de dis" tribuição agrupada do esqueleto. Note-se a variação acentuada na cor do piasme próximo aos vazios.

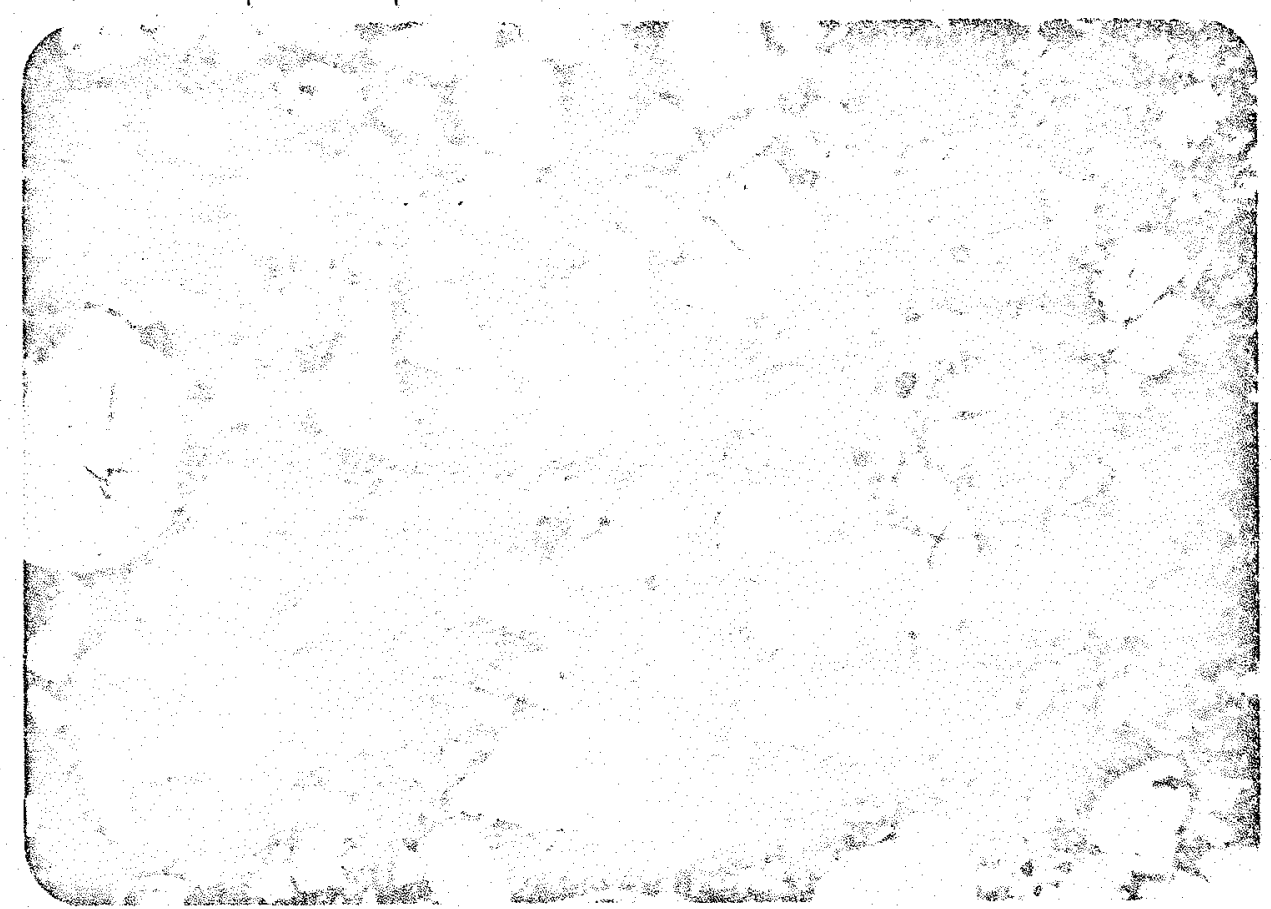

Figura 24 - Fotomicrografia (24X) relativa ao horizonte $A_{3}(15-25 \mathrm{~cm})$ do so 10 na ārea Cultivada por 1 ano: Presença de pequenos cutans a $\bar{r}$ gilosos de cor bruno amarelo claro no centro da foto. Note - se tambëm ao centro e à esquerda setores onde o plasma exibe fraca microagregaçäo. 


\subsection{Area CuTtivada por 5 Anos}

Depois de 5 anos de cultivo observa-se que no ho rizonte $A_{1}$ o plasma apresenta-se reduzido, se distribui irregular mente e se encontra em torno dos vazios de origem biológica ( Fi gura 26).

No horizonte $\mathrm{A}_{3}$ o plasma $\overline{\mathrm{e}}$ mais abundante e tambèm se distribui irregularmente. Os vazios, na maior parte, são de origem biológica, por vezes com paredes bastante alizadas (meta vazios) E revestidos por finos depósitos de argila bordejados por uma cinta vermelha (Figura 27 ).

No horizonte $B$ observa-se acentuada heterogeneida.de e descontinuidade da matriz do solo, orde se distinguem seto res essencialmente arenosos, de contornos festonados, superpostos e alternados com setores onde os grãos de esqueleto são envolvidos por plasma de cor bruno (Figura 28).

\subsection{Area em Pousio por 3 Anos apōs 3 Anos de Cultivo}

0 horizonte $A$ do pedon sob pousio apresenta-se com um fundo matricial muito semelhante ao da ärea cultivada por 5 anos, todavia, destacam-se concentrações de plasma de coloração bruno, provenientes do horizonte B, na forma de peletes fecais contendo areia fina e silte grosso misturados a residuos vege tais (Figura 29) que diferem na sua organização da encontrada no ecossistema natural (Figura 15). 


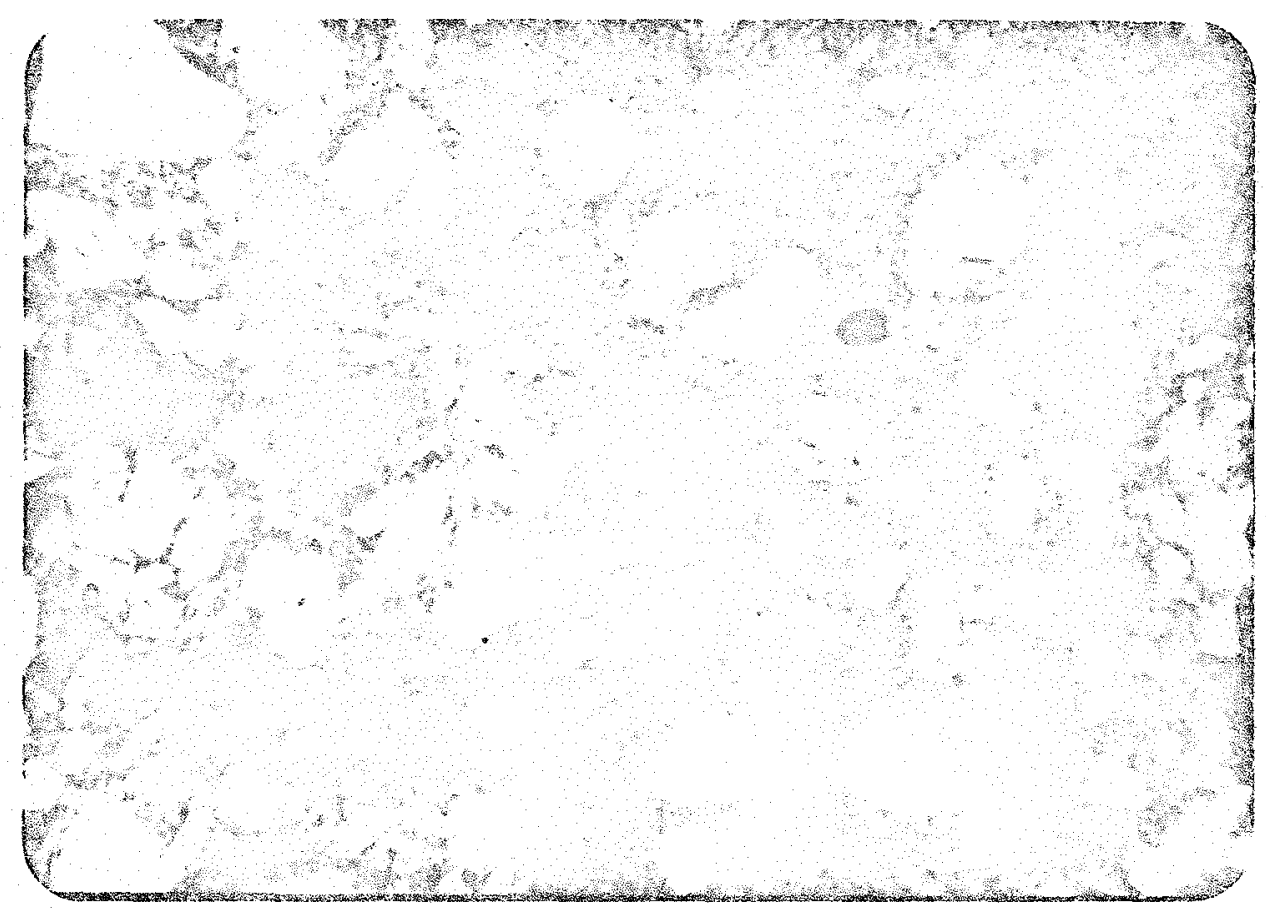

Figura 25 - Fotomicrografia (33X) relativa ao horizonte $B 12(35-75 \mathrm{~cm})$ do so lo na ärea Cultivada por 1 ano: Distingue-se o contato de dois fundos matriciais diferentes: $\bar{a}$ esquerda onde o plasma é bruno acinzentado, o esqueleto $\bar{e}$ abundante e existem microagregados e resíduos vegetais; à direita onde o plasma é bruno mais claro, mais abundante, formando uma massa continua, e a macroporosida-

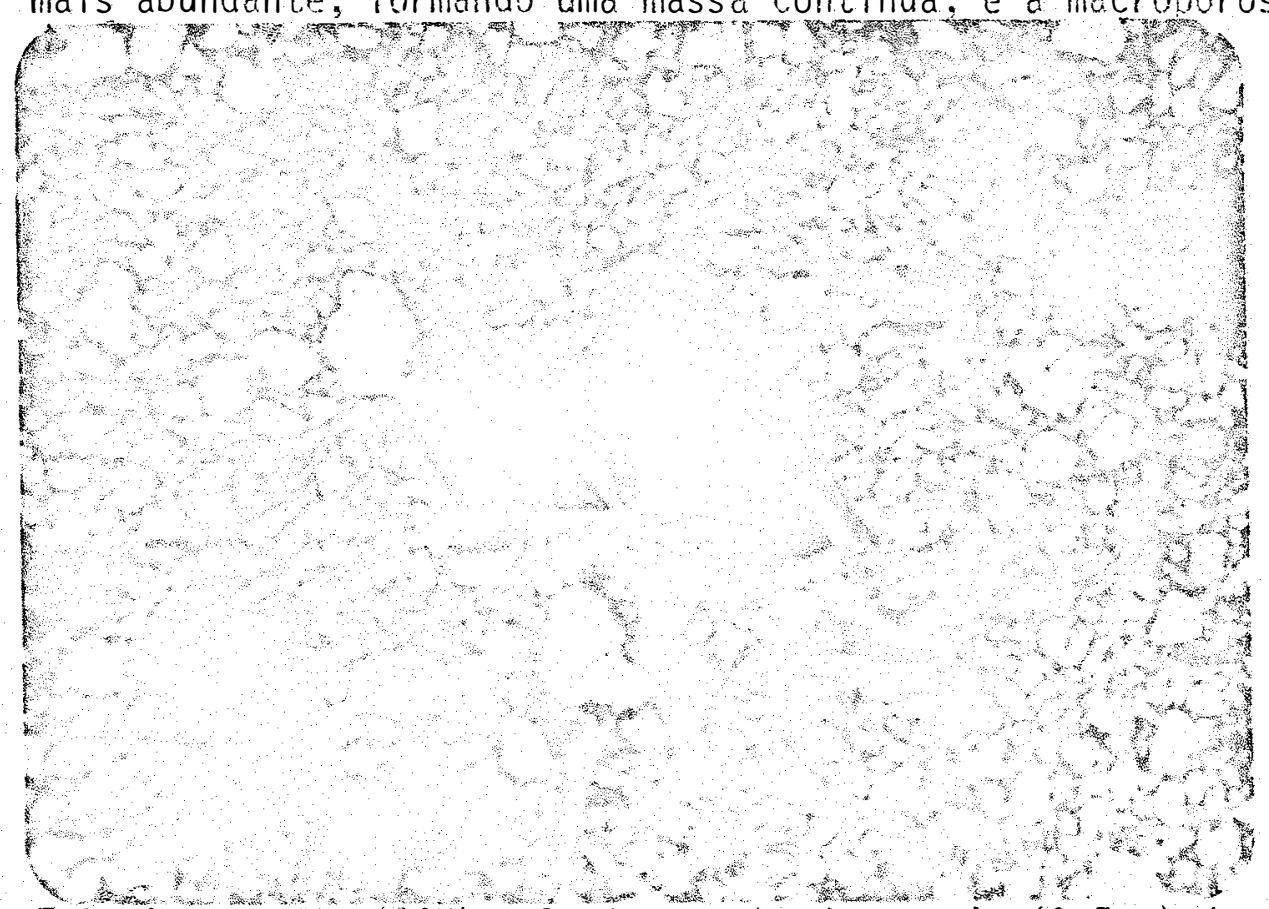

Figura 26 - Fotomicrografia $(12 x)$ rejativa ao horizonte $A](0-7 \mathrm{~cm})$ do solo na ārea Cultivada por 5 anos: Ocorrência de um plasma pouco abun dante que tende a se concentrar em torno dos vazios de origem biológica. No centro da fotografia observa-se um fragmento de carvão vegetal proveniente da queimada da vegetaçăo. 


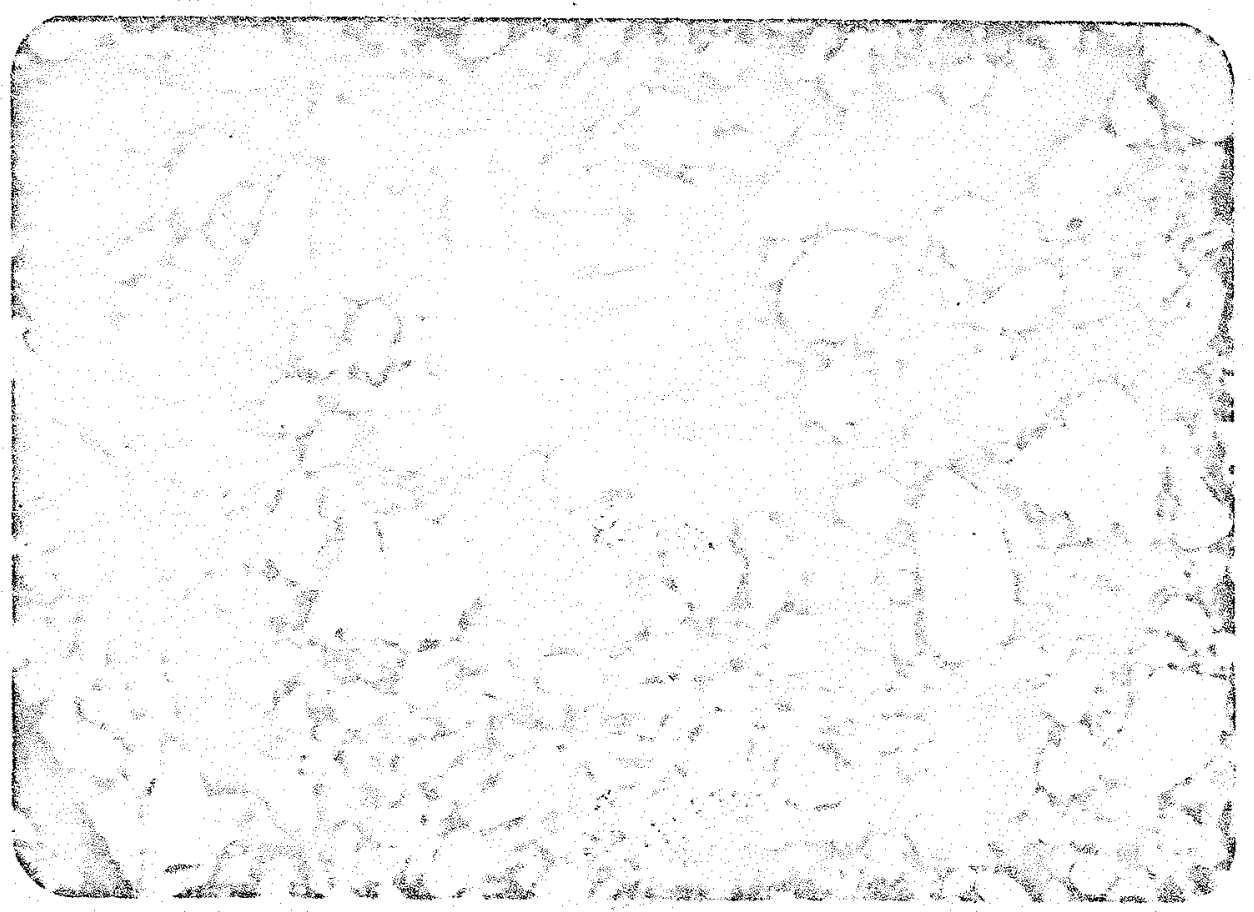

Figura 27 - Fotomicrografia $(33 X)$ relativa ao horizonte $A_{3}(7-17 \mathrm{~cm})$ do $50-$ 10 na ärea Cultivada por 5 anos: Plasma bruno irregularmente dis tribuido, separado por meta vazios revestidos por cutans de argila ladeados por uma bordadura de cor vernelha. No centro da fotografia aparece un gräo de staurolita.

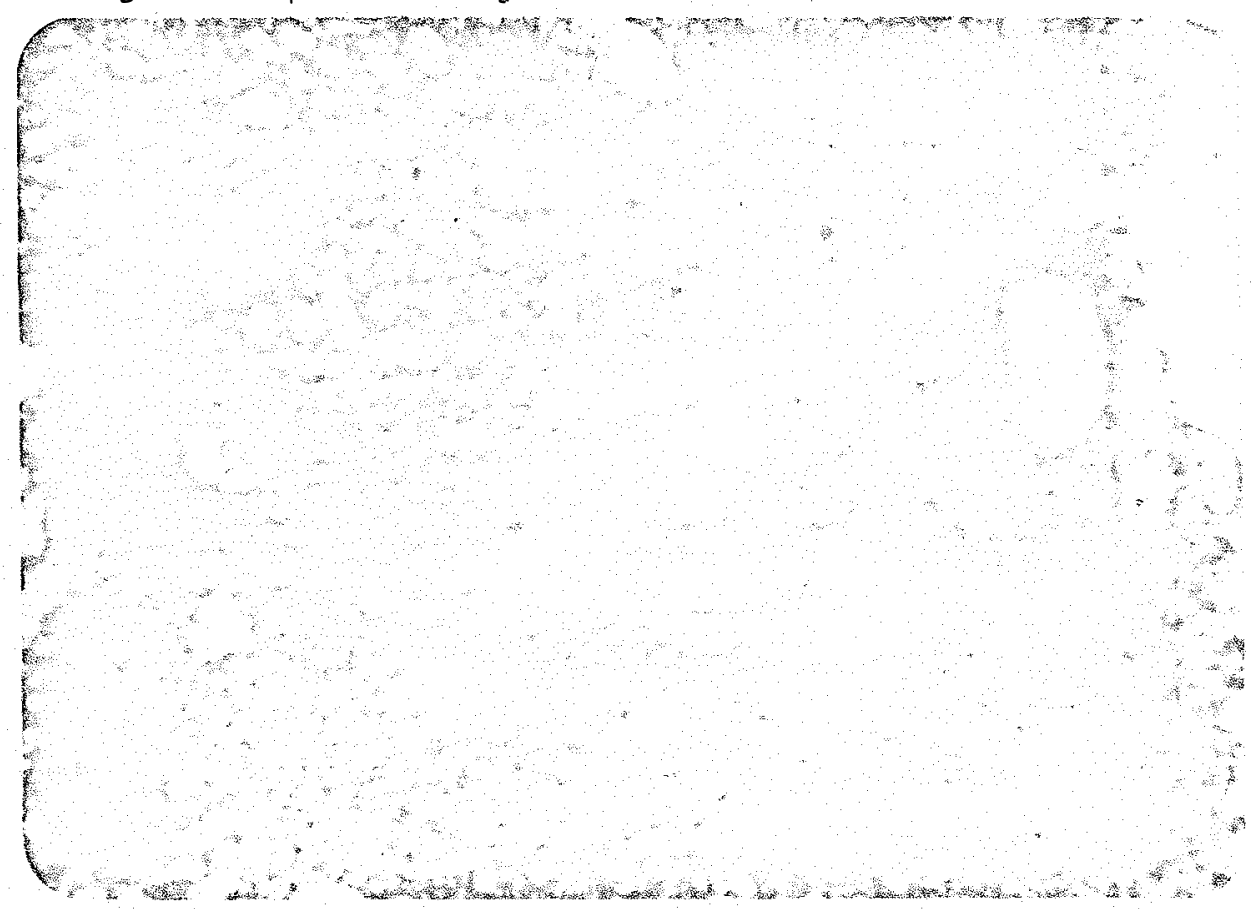

Figura 28 - Fotomicrografia (12X) relativa ao horizonte $B_{12}(32-45 \mathrm{~cm})$ do so 10 na área Cultivada por 5 anos: Aspecto da heterogeneidade do fundo matricial e da descontinuidade textural decorrente da alteração da estrutura do solo. Note-se a alternäncia de setores arenosos de contornos festonados com setores onde os grãos de quartzo estão envolvidos por um plasma de cor bruno. 


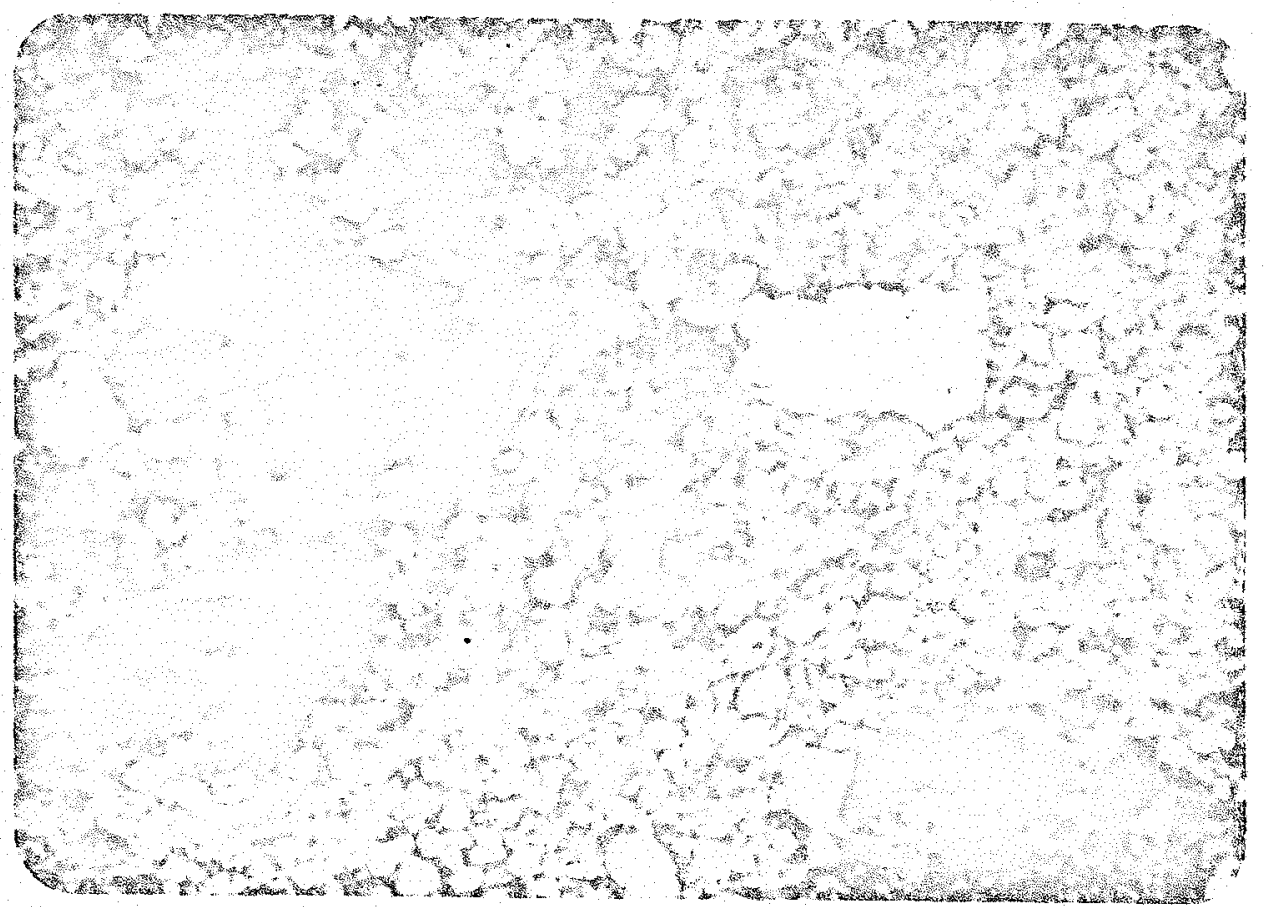

Figura 29 - Fotomicrografia (12X) relativa ao horizonte $A] 2(2-7 \mathrm{~cm})$ do so10 na äreà em Pousio: Em um fundo matricial enaulic, muito seme Thante ao da ārea cuitiváda por 5 anos, destacam-se peletes fecais de dianmetro de aproximadamente $1 \mathrm{~mm}$ que se anastomcsam for mando agregados compostos.

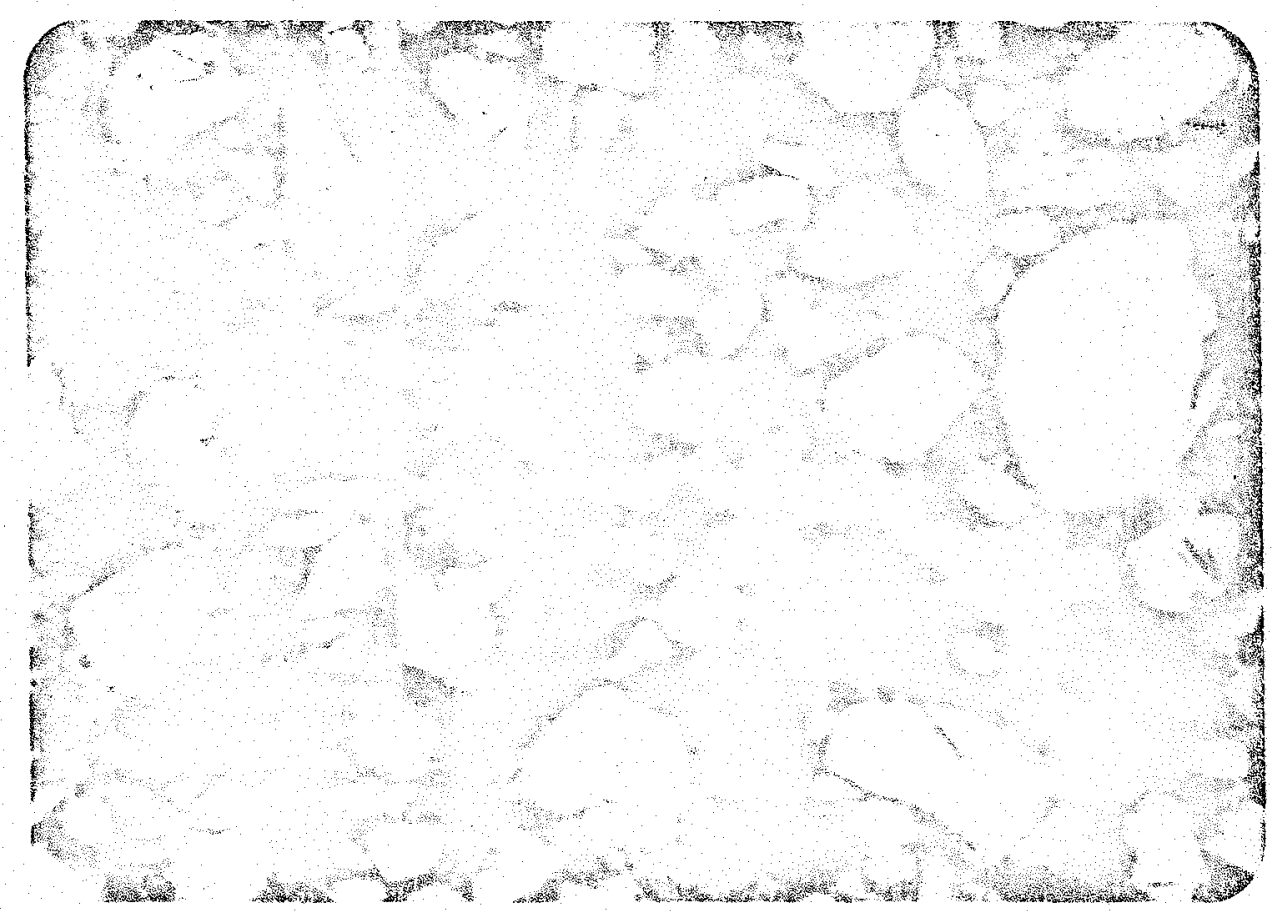

Figura 30 - Fotomicrografia (53X) relativa ao horizonte $812(30-40 \mathrm{~cm})$ do so 10 na ärea em Pousio: Nos limites de um canal, que se dispoe transversalmente na foto, observa-se grande quantidade de pele tes fecais oriundos de iniensa pedoturbação. 
No horizonte $B$ o fundo matricial apresenta-se se melhante ao do pedon bem drenado do ecossistema natural, contudo, observa-se a presenca de canais (channels, segundo BREWER, 1964 ) com abundante ouantidade de peletes fecáis (Figura 29) e não observa-se a heterogeneidade nem a descontinuidade existente no so 10 da área cultivada por 5 anos (Figura 28).

4.3.3.4.4. Mudanças na Seqúencia Floresta-cultivo-Pousio

o desmatamento provoca a iterações no solo que se expressam através da sua micromorfologia. E suficiente

apenas

1 ano de cultivo para provocar a destruição dos microagregados observa dos no horizonte $A_{12}$ do ecossistema natural (Figura 7) tornando a estrutura quase totalmente continua (Figura 23), onde o plas ma tende a segregar-se do esqueleto acentuando o padrão de dis tribuição agrupado (Figura 24).

A ocorrência de cutans de argila no horizonte

revela que a desestabilização da estrutura verificada no ecossis tema natural iende a ascender e afetar também a parte superior do perfil. Trata-se de uma degradação muito räpida da estrutura.

Por outro lado, a ocorréncia de partes menos den sas no horizonte $B$ indicam os efeitos de uma reorganização estru tural deste horizonìe, originariamente adensacio. A agregação, a cor mais escura do plasma e os residuos vegetais encontrados nas partes menos densas evidenciam a participação da fauna do solo no processo de reorganização da estrutura.

Depois de 5 anos de cultivo observa-se que além da diminuição da agregâção ocorreu um empobrecimento do plasma 
na parte superior do horizonte $A$ e uma acentuada deposição de ar gila nas paredes dos vazios na parte inferior acarretando a obs trução dos mesmos. A presença de depósitos de argila ladeados por uma cinta vermelha evidencia a segregação entre comostos fēr ricos e minerais de argila (Figura 27), consequéncia das condi ções redutoras causada pela renta circulação da água. Este pro cesso alëm de ocorrer com mais intensidade que no ecossistema na turai está presente a menor profundidade do perfil. A presença de forte heterogeneidade e descontinuidade textural ma matriz do ho rizonte $B$ (Figura 28) provavelmente è decorrente da interaçấo en tre a desestabilização da estrutura e a atividade biorōgica e po de estar relacionada com o processo de reorganização detectado a pós 1 ano de cultivo. Constata-se, portanto, que a degradação da estrutura atinge o horizonte $A$ e se intensifica no horizonte $B$.

A presença de peletes fecais no horizonte $A$ e no horizonte $B$ do solo submetido ao pousio, juntamente com residuos vegetais misturados a material mineral oriundo de horizontes mais profundos, indica uma forte pedoturbação causada pela fauna do solo. A auséncia de cutans, da heterogeneidade e descontinuidacie existentes na ärea cultivada por 5 anos atestam os benefícios da pedoturbaçäo.

Portanto, se a degradação è muito rāpida após primeiro ano de cultivo, a regeneração do solo com o desenvolvi mento da vegetação secundāria è igualmente espetacular. Com 3 anos de pousio, após 2 anos de cultivo, a atividade biológica apa rece como o principal fator de regeneração do solo. A microagre gação do horizonte $A_{1}$ é reconstituida (Figura 29), embora com pa drão diferente ao do ecossistema natural (Figura 15), ao passo 
que o restante do perfil é rehomogeneizado por uma intensa pedo turbação (Figura 30 ).

Conclui-se então que nas condições naturais a atividade biológica exerce um papel muito importante na manutenção ou na regeneração do estado de equilíbrio do solo, funcionando como uma espécie de anteparo protetor através do qual é realiza do o controle da āgua das chuvas, a adição dos resĩduos orgâni $\cos$ e a pedoturbação, o que não ocorre quando o solo é mantido sem a abertura vegetal protetora.

4.4. Dinâmica da Matéria Orgānica da Parte Superior do Solo

E no horizonte A do solo que ocorrem com maior in tensidade variações na matéria orgânica, especialmente se o ecos sistema sofre alteração como ocorre quando a vegetação é queimada e o solo cultivado.

Grande parte da matēria orgânica existente atē 100 cm de profundidade está contida no horizonte A (camada $0-20 \mathrm{~cm}$ ): cerca de $42 \%$ no ecossistema natural de $40 \%$ no ecossistema altera do (Tabela 14).

Visando verificar o estado da matéria orgānica no ecossistema natural, e as alterações que ocorrem em consequēncia do desmatamento, foi analisada uma amostra composta do horizonte A (a partir das amostras dos seus sub-horizontes) de cada um dos perfis envolvidos neste estudo.

As variações da matéria orgänica do solo podem ser avaliadas através do conteūdo de C existente nas diversas classes 
de frações granulométricas do solo, bem como da distribuição dos componentes do humus.

4.4.1. Fracionamento Granulométrico

A matēria orgânica contida nas frações granulomé tricas do solo varia qualitativamente: a contida na fração maior $(200-2.000 \mu \mathrm{m})$ corresponde à residuos vegetais pouco humifica

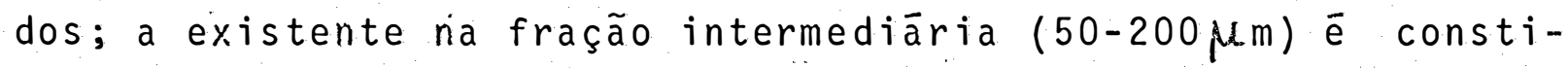
tuída de resijduos vegetais humificados; finalmente a encontra da na fração menor $(0-50 \mu \mathrm{m})$ compõe-se de compostos húmicos $1 \underline{i}$ gados a parte mineral (FELLER, 1979).

\subsubsection{Ecossistema Natural}

$\mathrm{Na}$ Tabela 15 constam as quantidades de C contidas no horizonte $A$ dos trēs pedons do ecossistema natural, dividi das em função das seguintes frações granulométricas: fração de

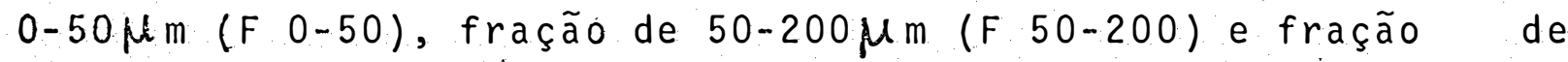
200-2000 Mm (F 200-2000); e na Figura 31 a distribuição relati va das referidas frações.

Verifica-se através da citada figura que no ecos sistema natural cerca da metade do C está contida na fração F-0-50, um terço na fração $F$ 200-2000 e um quinto na fração $F$ 50-200. Portanto, considerando-se a variação em função da granu lometria, a matéria orgānica do soilo no ecossistema natural é principalmente de natureza hümica associada à frações minerais fi nas.

observa-se através da. Tabela 15 que os pedons im perfeitamente e moderadamente drenados possuem quantidades 
TABELA 15. Distribuição do carbono nas frações F 200-2000 (200 a 2000 $(\mathrm{m})$, F 50-200 (50 a $200 \mu \mathrm{m})$ e F 0-50 $(0-50 \mu \mathrm{m})$ do horizonte $A$ do so 10 sob diferentes condiçöes do ecossistema.

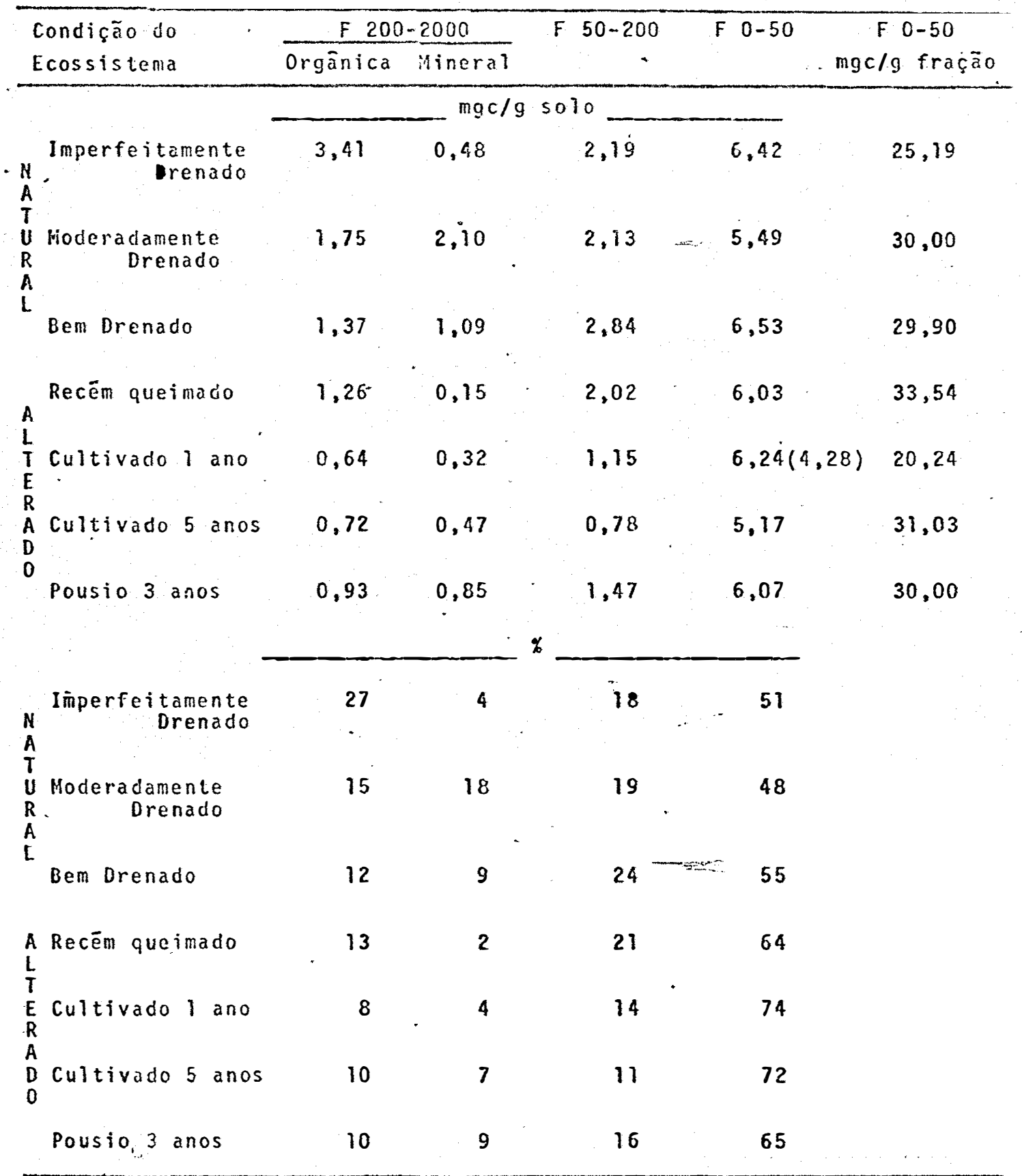

N.B. 0 valor entre parenteses (referente ä fração F $0-50$ da condição culti vado 1 ano) corresponde ao calculado considerando-se que a massa dä referida fração fosse idéntica/das demais condiçoes do ecossistema al
terado. 

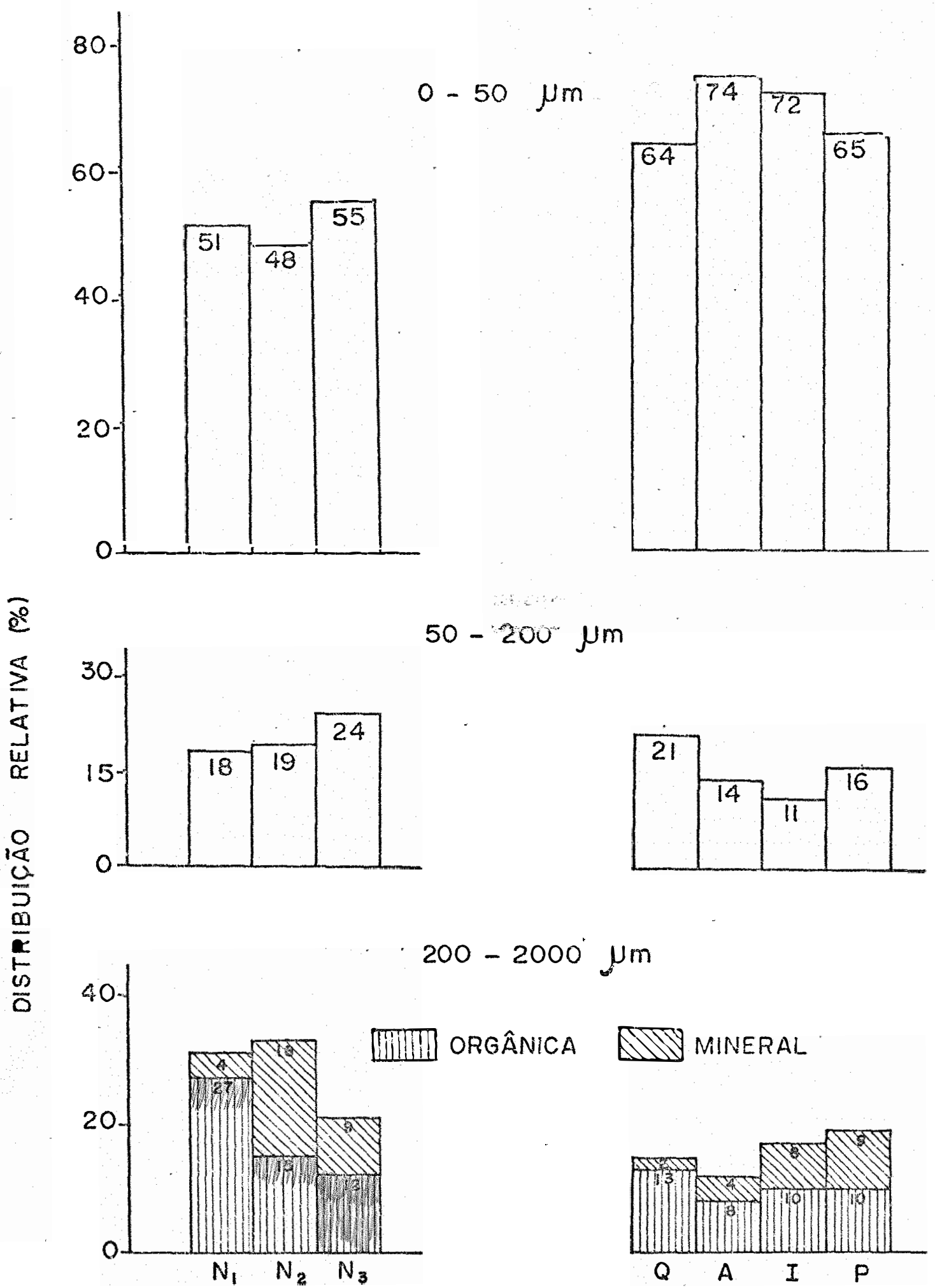

$$
50-200 " \mu \mathrm{m}
$$

$$
200-2000^{\circ} \mathrm{m}
$$

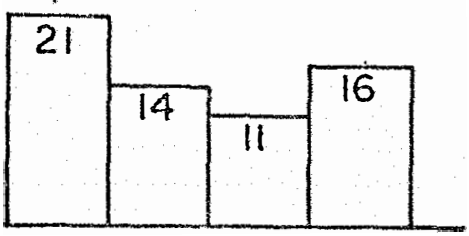

Figura 31. Distribuição relativa do carbono nas frações $0-50 \mu \mathrm{m}$,

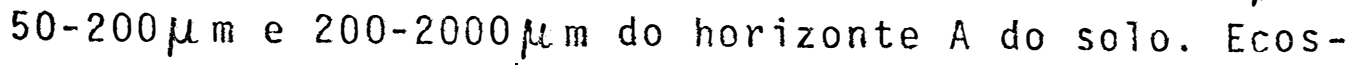
sistema natural: $\mathrm{N}_{1}$ - Imperfeitamente drenado, $\mathrm{N}_{2}-$ Moderadamente drenado, $N_{3}$ - Bem drenado. Ecoss is tema a t terado: Q-re cém-queimado, A-cultivado 1 ano, I- cultivado 5 anos, $P$-pousio de 3 anos (apös 2 anos de cultivo). 
idênticas de C nas frações F 50-200 e F 200-2000, diferindo to davia na proporção entre a parte orgä́nica e a parte mineral des ta ūitima fração e na fração $F$ 0-50, onde 0 imperfeitamente drenado possui maior quantidade de C . 0 pedon bern drenado difere dos dema is por apresentar mais $C$ nas frações $F 50-200$ e $F-50$ e menos $C$ na fração F 200-2000.

A variação existente entre o pedon bem drenado e os demais pode ser explicada pela diferença de drenagem. A dre nagem desempedida facilita a decomposição dos residuos pouco a? terados e a formação de compostos hümicos, que se associam ao complexo mineral, em virtude das condições favorāveis a ativida de microbiana. Por isto o pedon bem drenado apresenta maior quantidade de C na fração fina (F 0-50). Este fato é reforçado' quando verifica-se que, muito embora os demais pedons possuam maior quantidade de fração $F$ 0-50 (Tabela 8), a quantidade de C por unidade de massa da fração é semelhante a do pedon bem dre nado (Tabela 15 ); alēm do que tambēm não hā diferença con siderāiel na quantidade de silte (fração 2-50 $\mu \mathrm{m}$ ) entre os dois pedons (Tabela 8). Isto significa que a maior quantidade de $C$ da fração F 0-50 encontrada no pedon bem drenado não se deve a textura e sim a drenagem. Observa-se todavia que o pedon imperfeitamente drenado possue menor quantidade de C por unidade de massa da fração que os demais pedọns, inclusive em comparação ao pedon moderadamente drenado, o qual possui textura semelhante a sua no horizonte $A$. Isto indica que há tambēm variação na atra ção entre os compostos hümicos e a fração mineral, ou seja no pedon imperfeitamente drenado existe menor afinidade para a 
formação do complexo organo-mineral. Note-se ainda que, mesmo na fração grosseira (F 200-2000), a as sociação entre a parte orgāni ca e a parte mineral é menor no pedon imperfeitamente drenado (Figura 31 ). Estes fatos podem explicar a razão pela qual as per das de C são maiores no pedon imperfeitamente drenado (ver item 4.1.2.1.).

\subsubsection{Ecossistema Alterado}

Atravēs do exame da Figura 31 observa-se que no ecossistema alterado aproximadamente dois terços do C está conti do na fração $F$ 0-50 enquanto em cada uma das demais frações há cerca de um sexto. Verifica-se, portanto, que, em geral, no ecossistema alterado o solo contēm mais C na fração $F$ 0-50 que no ecossistema natural, ocorrendo o inverso com a fração $F$ 2002000. Analizando-se a Tábela 15 verifica-se que o aumento relati vo da fração $F$ 0-50 no ecossistema alterado deve-se ao decrësci mo das demais frações, constatando-se que a alteração do ecossistema afeta sobretudo o estoque de $C$ nos residuos vegetais e nem tanto o do complexo organo-mineral.

A variação na quantidade de C nas diversas frações da sequēncia queimada-cultivo-pousio pode tambēm ser analisada â travēs da Tabela 15 e da Figura 31.

$\mathrm{Na}$ fração $\mathrm{F}$ 0-50 hā relativamente mais C apōs 1 e 5 anos de cultivo que nas demais fases. Contudo em termos absolu tos observa-se que a quantidade de C na fração F 0-50 é seme 
lhante a exceção da fase cultivada por 5 anos, na qual se apre senta mais baixa. Por outro lado, expressos os valores em quan tidade de C por unidade de massa da fração, constata-se que a concentração de C é maior na fase recém-queimado e menor na fa se cultivado por 1 ano. As fases cultivadas por 5 anos e pousio possuem valores próximos, compreendidos entre as outras fases e semelhantes ao dos pedons bem e moderadamente drenados do ecos sistema natural. Em comparação ao pedon bem drenado do ecossis tema natural o pedon da fase recém-queimado, possui menor quan tidade absoluta de C porém valores relativos mais elevados.

A ocorrência de valores relativos de C mais eleva do na fração $F$ 0-50 após a queimada indicam que hä nesta fase maior afinidade para a formação de complexos organo-minerais. Is to é evidente sobretudo se considerar-se os valores expressos em relação a massa da fração, e que a diferença entre as quantidades de silte do horizonte A dos diferentes pedons é pequena (Ta belas $\mathrm{A}_{7}$ e $\mathrm{A}_{2}$ ), 0 que, de outro modo, inviabilizaria esta conclusão. O contrário ocorre após 1 ano de cultivo: embo ra a quantidade absoluta de C seja mais elevada, o que se deve a maior quantidade da fração, a concentração de C por unidade de massa é bem menor, acusando, portanto, menor afinidade entre - complexo orgânico e o complexo mineral. Deste modo não se pode considerar que haja aumento a quantidade de compostos húmi cos apōs 1 ano de cultivo.

Na fase cultivado por 5 anos hā menos C na fração' F 0-50 que na fase de pousio e no ecossistema natural.

A quantidade de C na fração F 50-200 diminui pro 
gressivamente com a queimada e o cultivo, e aumenta com o pou sio. Quanto a fração F 200-2000, observa-se que ela tambēm de cresce com a queimada e após 1 ano de cultivo, porēm aumenta após 5 anos de cultivo.

\subsubsection{Fracionamento do Humus}

A maior parte de C contido na camada superficial do solo, quer do ecossistema natural quanto do ecossistema alte rado, estā na fração 0-50 llm (Figura 31 ).

Com a finalidade de aprofundar o estudo da matēria orgānica do solo, determinou-se a distribuição qualitativa do humus contido na fração $0-50 \mu m$ obtida pelo fracionamento granu lomētrico (îtem 4.4.1.). E esta fração que encerra a maior par te do humus do solo.

\subsubsection{Ecossistema Natural}

0 humus do solo pode ser fracionado em ācido fūlvi co livre, humina, àcido hümico extraîdo pela soda, ácido fūivi co extraîdo pela soda, ācido hūmico extraîdo pelo pirofosfato de sōdio e ácido fūlvico extraído pelo pirofosfato de sōdio (DABIN, 1971).

A Tabela 16 contém as. quantidades de C encontrada' nos diversos componentes hümicos e a Figura 32 a distribuição relativa destes componentes contidos na fração $0-50 \mu m$ do hor zonte A dos trés pedons do ecosistema natural. observa-se atra vēs da citada figura que menos de $20 \%$ do C está sob a forma de 


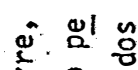

$\rightarrow 80$

8 少!

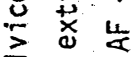

(5) i

용

1 을 ?

पू 10.0

$\ddot{0}$ 우

응 웅

응 웜

\&

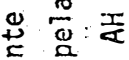

언욤 웅

논

용 웡

E 웅

$5 \geq$

品安

0 움 웅

- in o

요

는 윰

4.

总 芩

น.

तs $\frac{0}{8}$

웅 훈

焉

ㅇ․

를 冢

웡

葛

\&

否 100

号

点 1 告

동ㅇㄴ

号

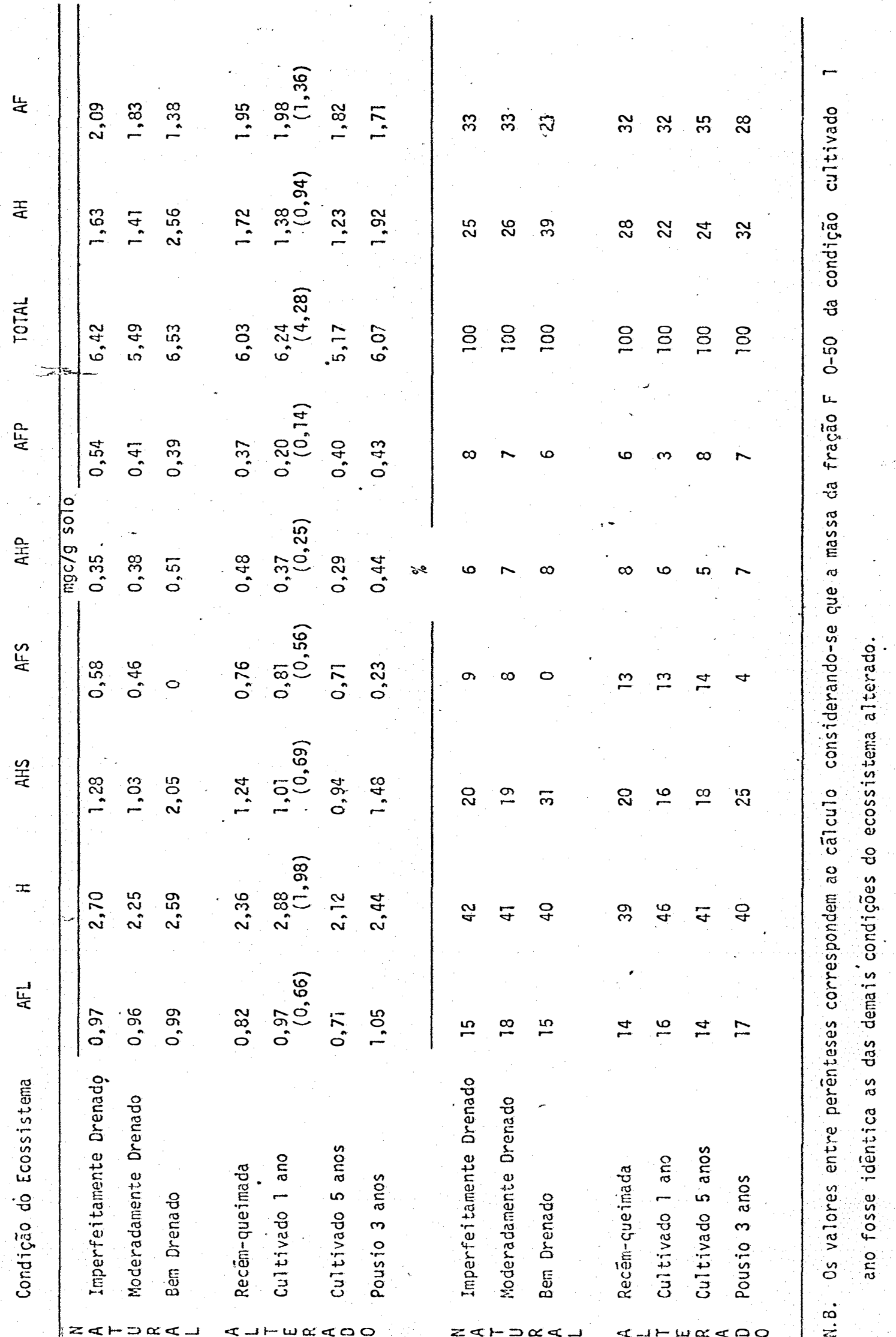


ECOSSISTEMA NATURAL

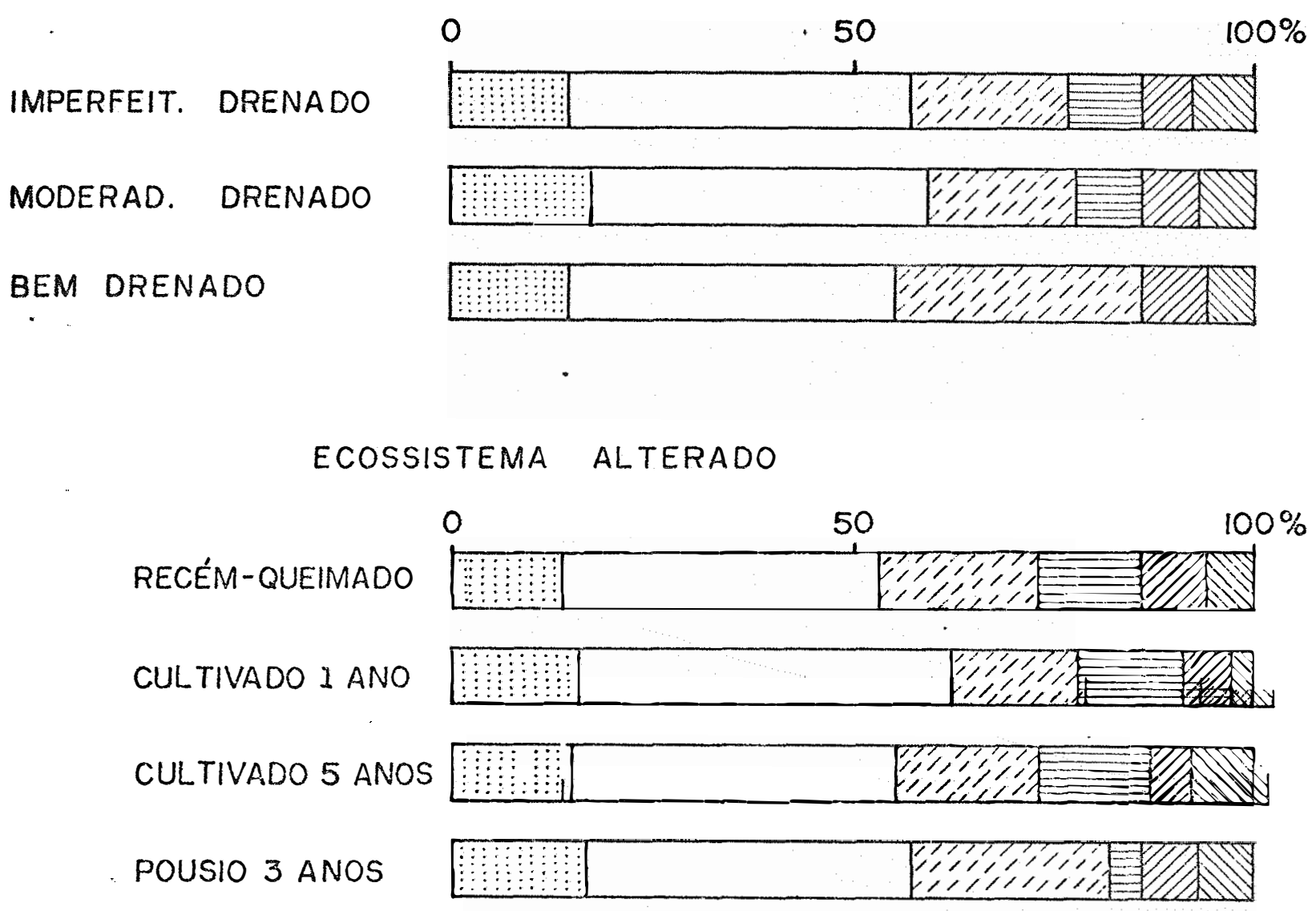

ÁCIDO FÚlVICO LIVRE 屏汤 ÁCIDO HÚMICO (SODA)

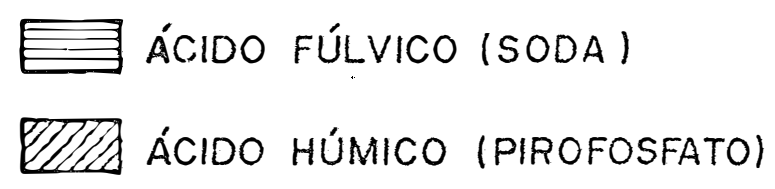

HUMINA

ÁCIDO fúlVICO (PIROFOSFATO)

Figura 32. Distribuição relativa dos compartimentos hūmicos

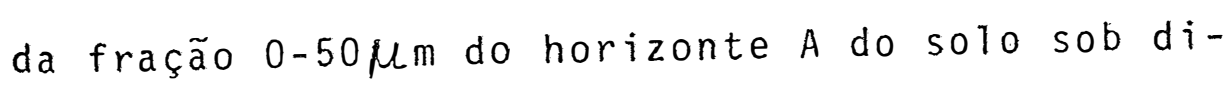
ferentes condições do ecossistema. 
ācido fūlvico livre e pouco mais de $40 \%$ estā sob a forma de hu mina. 0 s $40 \%$ restantes se distribui entre as demais frações, com variações na proporção de ācido hūmico extraídos pela soda(AHS), o qual predomina sobre as demais frações, e ácido fúlvico extra do pela soda (AFS).

Os dados aqui apresentados acusam percentuais de àcido fūlvico livre e humina inferior aos já encontrados no solo de terra firme da amazōnia (VOLKOFF e CERRI, 1981; VOLKOFF et alii, 1982; MANARINO et ali i., 1982).

Verifica-se que a distribuição dos componentes hü micos é idêntica nos pedons imperfeitamente e moderadamente dre nados, diferindo da distribuição do pedon bem drenado. As dife renças ocorrem sobretudo com os ācidos hūmicos e os ācidos fū vicos ligados e se evidenciam quando se considera a distribuição percentual de àcidos hūmicos e ácidos fūivicos (Tabela 16). 0 pedon bem drenado possui maior conteūdo de ácidos hümicos e me nor de ácidos fūlvicos extraídos pelo pirofosfato de sōdio, a tém de não possuir ácido fúlvico extrāido pela soda. Portanto, pare ce haver um favorecimento da drenagem ã manutenção do ācido hūmi co em detrimento à manutenção do ācido fūivico.

\subsubsection{Ecossistema Alterado}

Observa-se atravēs da anālise da Figura 32 que ocor rem modificações na distribuição das frações do humus do solo de pois do desmatamento. Estas modificações acontecem mais precisamente nas frações extraîveis pela soda: o ācido bümico dimi 
nui com a queimada e o cultivo e aumenta com o pousio,ocorrendo o inverso com o àcido fülvico.

Hā tambēm uma nîtida variação na distribuição da humina e do àcido fūlvico extraîdo pelo pirofosfato de sōdio apōs o primeiro ano de cultivo: aumenta a proporção de humina en quanto decresce a de àcido fūlvico extraído pelo pirofosfato. Excluindo esta ocorrência, constata-se que não hā variação con siderāvel da fração extraîvel no ecossistema alterado, o que tambëm foi verificado por TURENNE (1977) e MANARINO et alii , $1982)$.

Quanto a variação entre os diversos componentes ex traiveis, do mesmo modo que TURENNE (1977) detectou-se diminui ção na quantidade de ācidos fūlyicos na sequência cultivo-pousio, porēm. apenas na fração extraível pela soda, e não nas demaisfra ções de natureza fúlvica, e com um correspondente aumento de ači dos hümicos, especialmente o extraído pela soda (Tabela 16). 0 aumento de àcidos hümicos tambēm foi verificado por MANARINO et alij (1982), contudo envolvendo tanto o ácido hümico extraído pela soda, como, e principalmente, o extraido pelo pirofosfato de sódio.

0 aumento na quantidade de àcidos fúlvicos observa do por TURENNE (1977) a partir do segundo ano de cultivo foi aqui observado apenas na fração extraída pela soda e desde logo de pois da queimada.

Em resumo, no ecossistema natural a drenagem menos impedida favorece a manutenção dos à cidoshüriicos e a điminuição dos àći dos fūrvicos sem diminuição na quàntidade de matéria orgānica 
total. Após o desmatamento, o solo sendo cultivado ocorre o in verso: há diminuição no teor de matēria orgānica total, na quan tidade de ácidos húmicos e aumento na quantidade de ácido fúl vico extraído pela soda. Todavia, se após o cultivo a terra fí car em pousio, o desenvolvimento da vegetação acarreta aumen tos no teor de matéria orgānica total, com consequente recupe ração do nível de ácidos húmicos e abaixamento do teor de āci do fūlvico extraido pela soda.

\subsubsection{Evolução da Matēria Orgānica}

Com auxilio dos dados apresentados na Tabela

e na Figura 33 delinear-se-á o processo de evolução da matéria orgānica em consequēncia da queimada, do cultivo e do pousio.

Em decorréncia da queimada parte da liteira sofre combustão, liberando cinzas ricas em bases que se incorporam ao ao solo. A quantidade de residuos vegetais sobre o solo decres ce, juntamente com os residuos pouco alterados existentes no solo, enquanto hā um discreto acréscimo dos compostos hümicos do complexo. Isto deve-se sobretudo ao aumento da afinidade en tre os compostos orgānicos e a fração mineral devido à libera ção de cargas dependentes e a adição de bases (vide item 4.3. 3.2.1). O ácido hümico extraído pela soda começa a decrescer e o âcido fūlvico extraido pela soda a aumentar. A quantidade de C existente no solo do ecossistema natural ate $1 \overline{5} \mathrm{cr}$ de profundida de passa de 3.205 para $2.396 \mathrm{~g} / \mathrm{m}^{2}$, ou seja hā um decrescimo de $25 \%($ Tabela 17$)$. 


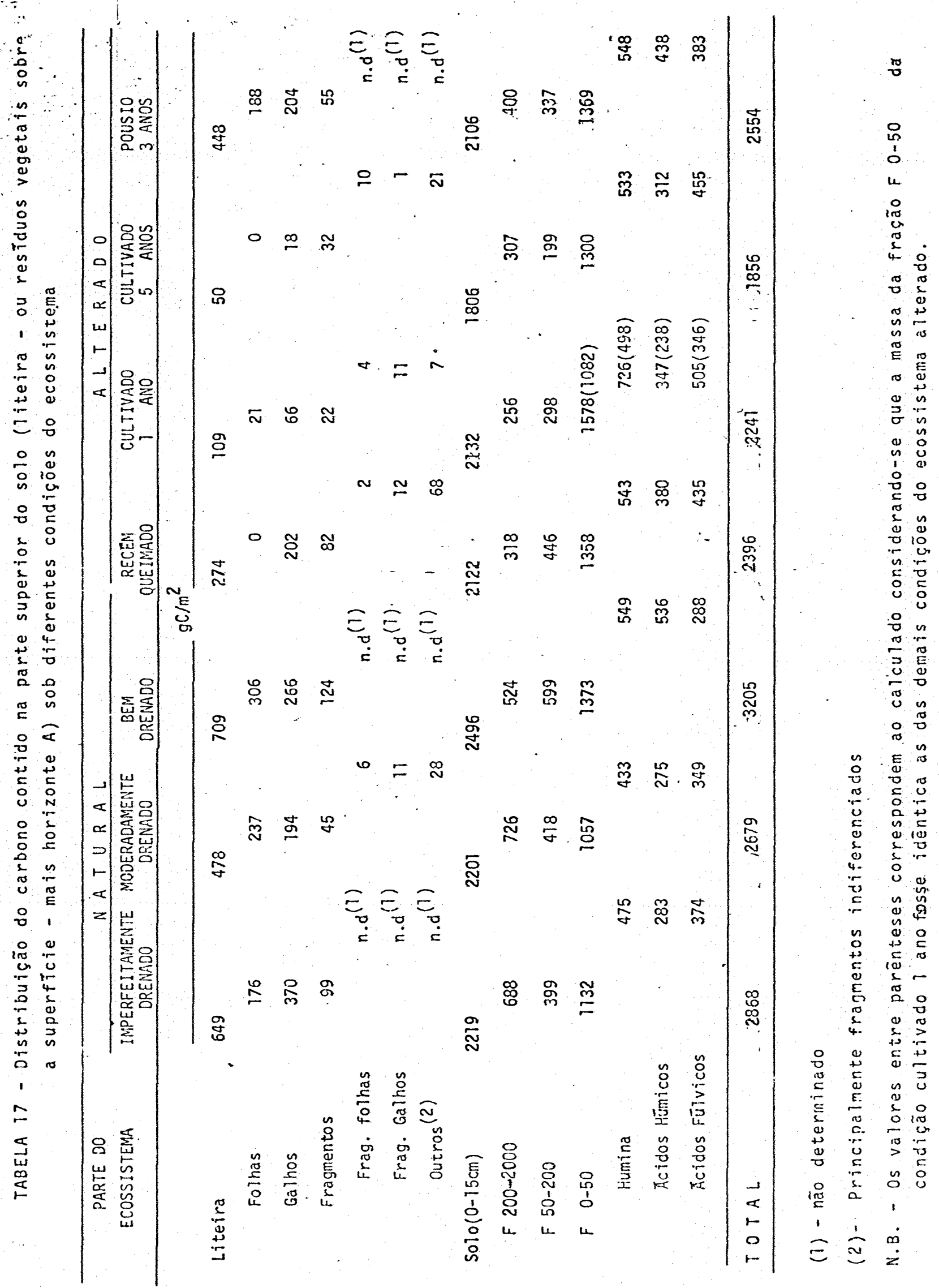




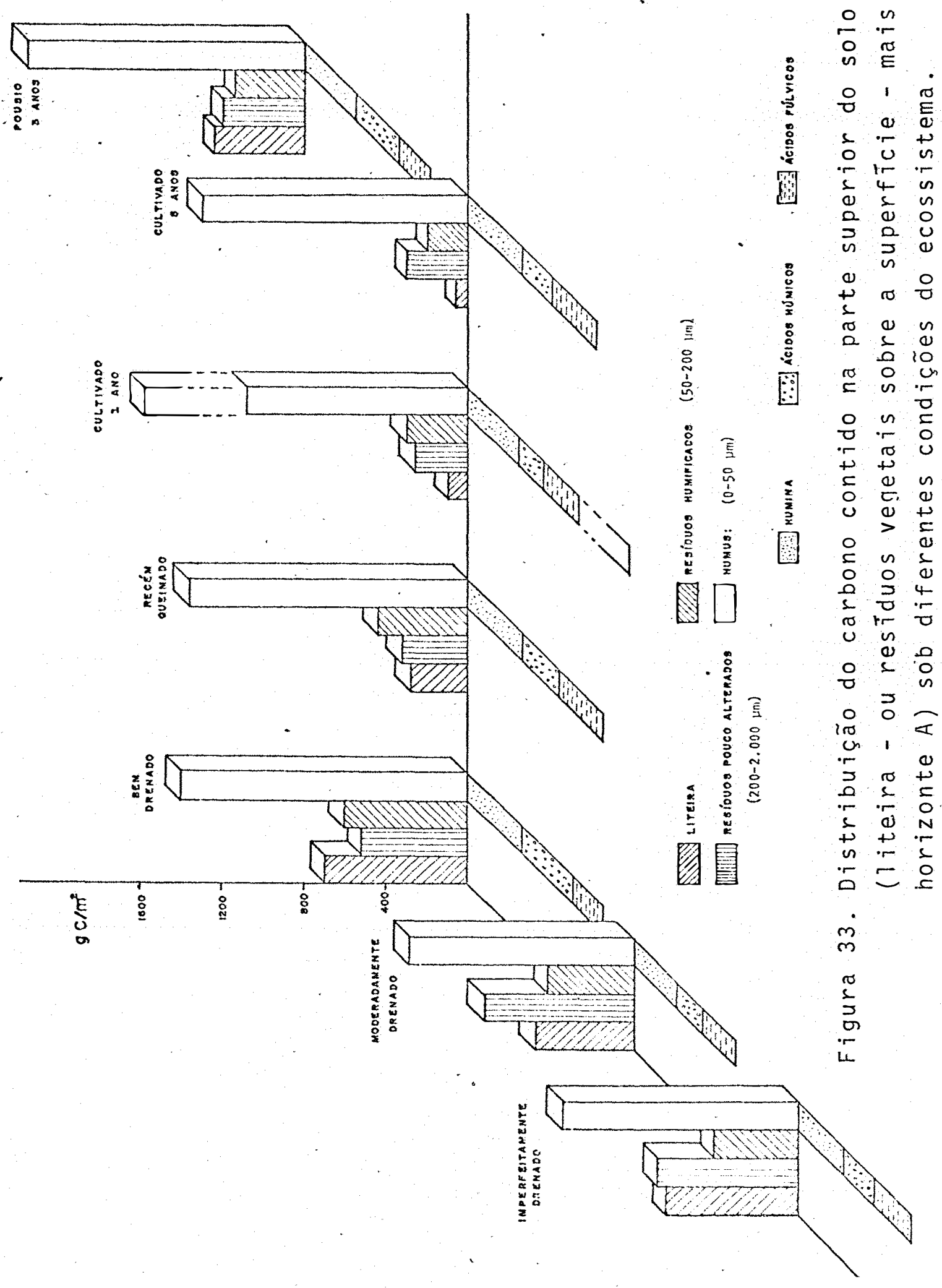


Durante o primeiro ano de cultivo os residuos da superfície se decompoem, porém; por não haver reposição dos re siduos em quantidade suficiente, como acontecia no ecossistema natural, ocorre pequeno decrescimo na quántidade de matéria orgânica total na parte superior do perfil, decorrente da mine ralização dos residuos vegetais e de uma provāvel reversão na afinidade entre os compostos orgānicos e minerais, provocada pela queimada, acompanhada da migração de compostos orgânicos' em profundidade. Com efeito óbserva-se que há diminuição do pH e evidencias da translocação de bases para os horizontes mais profundos (vide îtem 4.3.3.2.2). Alēm disto, continua ocorren do variação nos compartimentos húmicos: o ācido hūmico conti nua diminuindo, envolvendo também a fração extraída pelo piros fosfato de sódio, e o ácido fūlvico extraído pela soda conti nua aumentando; este aumento agora acompanhado pelo de humina. A quantidade de C contida no solo até $15 \mathrm{~cm}$ de profundidade passa para $2.241 \mathrm{~g} / \mathrm{m}^{2}$, decrescendo portanto mais $5 \%$ em relação ao ecossistema natural, mesmo sem considerar-se a ocorrência do aumento da quantidade de C (Tabela 17) devido a textura do solo ser mais fina que a das demais fases (Tabela 8).

Não dispõe-se de dados referentes as fases inter mediārias entre 1 e 5 anos de cultivo, porēm, após este tempo observa-se que ocorre um decréscimo acentuado no teor de matê ria orgânica total do solo: a quantidade de C existente até 15 $\mathrm{cm}$ de profundidade baixa para $1.856 \mathrm{~g} / \mathrm{m}^{2}$, o que corresponde a $42 \%$ da encontrada no ecossistema natural sob condição de boa drenagem e a $69 \%$ da encontrada no pedon moderadamente drenado' 
- qual menos acumula matéria orgânica. Há um ligeiro aumento da fração F 200-2000, provavelmente decorrente da capina da vegetação secundāria efetuada antes do plantio, e um nîtido decréscimo da fração F 50-200. Quanto a fração hümica verifica-se que tendem a se estabilizar as variações das frações extraídas pela soda e a variar as frações extraídas pelo pirofosfato de sódio, contudo se gundo o mesmo padrão anterior: diminuição de ācido húmico e aumen to de ácido fūrvico.

Em resumo, pode-se dizer que apōs o desmatamento' ' não havendo mais deposição de residuos vegetais em grande quantidade, a decomposição progressiva dos ainda existentes suprem a formação da fração F 50-200, que por sua vez alimenta a formação dos compostos húmicos, especialmente do ácido fūivico extraído pe. la soda, denotando o predominio da via de solubilização no proces so de humificação. Apōs o primeiro ano começa a haver tambēm a ocorréncia da via de condensação e a humina tende a aumentar. Po rém, a esta altura, o teor de matēria orgānica total inicia a de crescer, baixando consideravelmente após 5 anos de cultivo. Com isto o processo decomposição tende a estabilizar as frações ex traidas pela soda devido a falta de residuos vegetais que alimentem o processo global de decomposição, passando a haver conversão entre as frações extraĩdas pelo pirofosfato de sódio (Tabela 17).

Com o pousio, ao contrārio, ocorre a produção elevada de resĩduos pela vegetação secundāria. A quantidade de C contida no solo, até $15 \mathrm{~cm}$, aumenta para $2.554 \mathrm{~g} / \mathrm{m}^{2}$ o que correspondendo a $80 \%$ da encontrada no ecossistema natural (Tabela 17). os novos residuos realimentam o processo de decomposição, contri- 
buindo tanto para o aumento do teor de matēria orgânica total do solo quanto para a formação dos ācidos húmicos e degradação dos ācidos fūtricos. Em suma, com o desenvolvimento da vegeta ção natural secundāria o sentido do processo de decomposição se inverte em relação ao que ocorre quando o solo è mantido sob cultivo (Figura 33 ). 


\section{CONCLUSOES}

Os solos sob ecossistema florestal "estudados possuem drenagem variāvel, incluindo as classes imperfeitamen te, moderadamente e bem drenados. Estes solos possuem em comum uma organização pedológica caracterizada por um adensamen to natural ao nível do horizonte $B$, o qual é agravado nos pe. dons de textura mais fina, onde a macroporosidade é muito reduzida e as condições de encharcamento prolongado menos favorāvel à humificação. Portanto as variações nas condições da drenagem além de influirem na quantidade da liteira produzida pela vegetação, afetam o estoque de matēria orgānica da parte superior do perfil.

os dados obtidos indicam que no ecossistema na tural o adensamento do horizonte $B$ é causado pela evolução de um material endurecido de composição granulométrica variável e concorre para a diminuição dos ācidos hūmicos e aumento dos àcidos fūlvicos, causando a desestabilização do complexo organo-mineral, a migração de argila e a obstrução dos macro- 
poros. Este processo parece ter seus efeitos atenuados pela presença de um horizonte $A$ agregado mantido às custas de cons tante adição de matéria orgānica, causando, todavia, um estado propício as alterações físicas e químicas quando o solo é desmatado e cultivado.

A queimada, embora não cause prejuĩzos imediatos ao solo, chegándo mesmo a melhorar suas características quỉmicas, cria as condições favorāveis à fortes alterações fí sicas caso o desenvolvimento da vegetação natural seja impedi do .

Não havendo mais a vegetação os resîiduos prove nientes da queimada, juntamente com os pré-existentes no so10, decompõem-se sem que haja reposição. Inicialmente não ocorre variação no teor de matéria orgânica total do solo. Todavia, a decomposição provoca variações na qualidade da matéria orgânica e começa a afetar a estrutura do solo, detectando-se na densidade do solo um aumento de $0,16 \mathrm{~g} / \mathrm{cm}^{3}$ nos quatro primeiros centímetros. Hā a movimentação descendente de compostos orgánicos no perfil e, na camada superficial os resíduos vegetais humificados suprem a formação dos compostos ligados ao complexo mineral, ao mesmo tempo que são mantidos pela decomposição dos resíduos vegetais pouco alterados. Os compostos ligados ao colóides minérais tambēm são afetados e a quantidade de àcido hūmico passa a diminuir formando-se àc do fúlvico.

0 processo de alteração evolui e, depois de 1 ano, apōs o solo haver sido cultivado, observa-se uma diminui 
ção no teor de matēria orgānica nos dez primeiros centímetros do solo, bem como um aumento na densidade do solo da ordem de $0,15 \mathrm{~g} / \mathrm{cm}^{3}$, os quais estão associados a alterações microestrú turais: o plasma fica denso e tende a segregar-se do esqueleto. A fração hūmica do solo mantēm-se suprida pela decompos $\underline{i}$ ção dos residuos vegetais, porém o àcido hūmico continua dimi nuindo sem um consequente aumento de àcido fūtvico mas sim de humina.

0 que afeta o solo desmatado não ē o cultivo em si, pois ele pouco mobiliza o solo além de não ser intensi vo, mas sim a erradicação da vegetação, que expõe o: solo à condições microclimáticas mais adversas, associada a ausēncia do suprimento adequado de matéria orgānica, especialmente de matéria orgānica humificada. Occrre então uma maior desestabilização do complexo organo-mineral que aquela observada nos locais com drenagem deficiente no ecossistema natural. Verifí ca-se a migração de argila e a obstrução parcial dos poros ao nivel do horizonte $A$, os quais concorrem para o aumento das perdas das partículas argilo-húmicas, além de limitarem o processo de humificação.

Caso se prolongue o cultivo, as alterações na estrutura são marcantes e, apesar de manter a maioria dos parâmetros quỉmicos em nîveis pelo menos idênticos ao do ecossistema natural, o solo torna-se improdutivo.

As alterações na estrutura estão sempre associadas à matéria orgānica. Após o quinto ano de cultivo, a 
quantidade de matēria orgānica sófre um decréscimo acentuado, especialmente nos 10 primeiros centimetros, chegando a dimi nuir $14 \%$ até 1 metro de profundidade. A conversão de resîduos pouco alterados em compostos húmicos é interrompida pela falta de suprimento, bem como as alterações nas quantidades relativas das frações do humus.

Todavia, após o segundo ano, se o.cultivo for interrompido, o desenvolvimento da vegetação natural secundá ria (capoeira) concorre para o progressivo aumento da quantidade de resíduos que associado à elevada atividade da fauna do solo depois de três anos é capaz de inverter a direção do processo de alteração provocado pelo desmatamento; em conse quência o solo tende a retornar às condições originais. 


\section{LITERATURA CITADA}

ARAUJ0, J.V. et alii, 1973. Levantamento exploratōrio de solos da folha SA 23. São Luiz e parte da folha SA 24. Fortaleza. In: BRASIL, Departamento Nacional de Produção Mineral. Projeto RADAM. Levantamento de Recursos Naturais. Rio de Janei ro, DNPM, V.3.

BABEL, U., 1971. Gliederung und beschreibung des humus pro fil, in mitteleuropaschen wäldern. Geoderma, Amsterdam, $\underline{5}: 297-324$.

BAIARDI, A., 1981. Amazōnia: uma região ferida de morte. Rev . Bras. Tecnol., Brasiilia, 12(4):17-29.

BAIARDI, A., 1983. Desmatamento: o caso da Amazōnia brasileira. Rev.Bras. Tecnol., Brasilia, 14(2):5-19.

BARBOSA, G.V. e M.N. PINTO, 1973. Geomorfologia da folha SA. São Luiz e parte da folha SA 24. Fortaleza. In: BRASIL, De partamento Nacional de Produção Mineral. Projeto RADAM. Le vantamento de Recursos Naturais. Rio de Janeiro, DNPM,v.3. 
BATISTA, D. da C., 1969. Inventārio científico da Amazônia. In: LIMA, A.A. de A. et alii. Problemātica da Amazônia. Rio de Janeiro, Casa do Estudante do Brasil, p.221-244.

BETSCH, J.M., 1979. Biologie des sols. In: SCHIRLE, A. et alii, Ed. L'ecosysteme forestier guyanais. Etude et mise en valeur. Cayenne, ORSTOM, p.54-56. (Bulletin de liaison du groupe de travaux n.2).

BOULET, R., 1981. Etude pedologique des bassins versants ECEREX. Bilan de la cartografie. In: SCHIRLE, A. et alii, Ed L'ecosys teme forestier guyanais. Etude et mise en valeur. Cayenne, ORSTOM, p.33-44, (Bulletin de liaison du groupe de travaux $n$. $4)$.

BREWER, R., 1964. Fabric and Mineral Analysis of Soils. New York, John Willey \& Sons, 470p.

BUCKMAN, H.O. e N.C. BRADY, 1976. Natureza e propriedades dos so los. Compendio Universitário de edafologia. S. Paulo/Rio de Janeiro. Livraria Freicas Bastos, 594 p. 4ä. edição em portü gues (traduzido do original "The nature and properties of soils" por Antonio B. Neiva Figueiredo Fo).

CERRI, C.C.; B. de P: EDUARDO e B. VOLKOFF, 1983. Biomassa micro biana do latossolo amarelo sob vegetação natural e modificada pelo cultivo. In: SOCIEDADE BRASILEIRA DE CIENCIA DO SOLO, Campinas. Programa e Resumos do XIX Congresso Brasileiro de Ciência do solo. 126. (Resumo nọ 38). 
CHAUVEL, A. (1982). Os latossolos amarelos, ālicos, argilosos dentro dos ecossistemas das bacias experimentais do INPA e da região vizinha. Supl. Acta Amazonica. Manaus. 12(3):4760 .

CUNNINGHAM, R.K., 1963. The effect of clearing a tropical fọ rest soil. J. Soil Science, 0xford. 14(2): 334.345 .

DABIN, B., 1971. Etude d'une méthode de fractionnement des matiéres humiques du sol. Science du Sol. Paris, 1:47-63.

DABIN, B., 1982. Relação entre a evolução dos compartimentos' húmicos sob cultura e os fatores físicos e químicos da ferti lidade em diferentes solos tropicais. In: CERRI, C. C. et alii, Ed. Anais do Colóquio Regional sobre Matéria Orgãnica. do Solo. Piracicaba, CENA-USP/PROMOCET, p.87-96.

DANTAS, N.; I.A. RODRIGUES E N.R.M. MULLER, 1980. Estudos fi tosociológicos do trópico húmido brasileiro. Aspectos fitos. sociológicos de mata sobre latossolo amarelo em Capitão Poço. Parā, Belēm. EMBRAPA/CPATU. 23p. (boletim de Pesquisa, nọ 9).

DANTAS, M. e A. de 0. MATOS, 1981. Estudos fito-ecológicos do. trōpico ümido brasileiro. III Conteūdo de Nutrientes em cin. zas de floresta e capoeira, Capitão Poço-PA. Belēm, EMBRAPA/ CPATU. 23p. (Boletim de Pesquisa, no 24).

DINIZ, T.D. de A.S. e T.X. BASTOS, 1980. Efeito do desmatamento na temperatura do solo em região equatorial ümida. Belém, EMBRAPA/CPATU, 14p. (Boletim de Pesquisa, no 7). 
EMBRAPA, 1979. Manual de métodos de anālise de solo. Rio de Ja neiro, Serviço Nacional de Levantamento e Conservação de so los,

EMBRAPA, 1981. Sistemas de Produção com plantas perenes em con sōrcio duplo para o trópico úmido brasileiro - Resultados 1

preliminares. Belém, Centro de Pesquisa Agropecuāria do Tró pico Omido, $117 p$.

EWEL, J.; C. BERISH; B. BROWN, N. PRICE A J. RAICH, 1981. S1ash and burn impacts on a Costa Rican wet forest site. Ecology. Durham, N.C., 62(3): 816-819.

FALESI, I.C.; A.R.C. BAENA e S. DUTRA, 1980. Consequências da exploração agropecuāria sobre as condições físicas e químicas dos solos das microrregiões do nordeste paraense. Belém EMBRAPA/CPATU. 49p. (Boletim de pesquisa, nọ 14).

FASSBENDER, H.W., 1975: Quimica de Suelos com énfasis en sue los de américa Tatina. San José, Instituto Interamericano de Cooperacion para la Agricultura, 398p.

FEARNSIDE., P.M., 1979. O desenvolvimento da floresta amazô nica: problemas prioritārios para a formulação de diretrizes. Acta Amazônica. Manaus, 9(4): 123-129 (suplemento).

FEARNSIDE, P.M., 1982. Desmatamento na Amazōnia brasileira : com que intensidade vem ocorrendo? Acta Amazōnica. Manaus, 12(3): $495-497$. 
FELLER, C., 1979. Une méthode de fractionnement granulometrique de la matiére organique des sols, application aux sols tro picaux, à textures grossiēres, tres pauvres en humus. Cah. ORSTOM; SER: Pedo1. Paris, 17(4): 339-346.

FITTKAU, E.J.; U. IRMLER; W.J. JUNK; F. REISS e G.W. SCHMIDT, 1975. Productivity, biomass, and population dynamics in amazonian water bodies. In: GOLLEY, F.B. e E. MEDINA, Ed. Tropical ecological systems. Trends in terrestrial and aquatic research. New York, Springer-Verlag, p.290. (Ecological Studies, V.11).

FLORESTA, H., 1982. Premier temps de la régénération aprés coupe papetier: ARBOCEL. In: SCHIRLE, A. et alii, Ed. L'eco systeme forestier guyanais. Etude et mise en valeur.Cayenne, ORSTON, P. 185-215. (Bulletin de liaiason du groupe de tra vaux, no 2).

FRANCISCO, B.H.R.; P. LOEWENSTEIN; 0.F. da SILVA e G.G. SILVA, 1971. Contribuição à geologia da folha São Luiz (SA 23) no estado do Pará. III. Estratigrafia. IV. Recursos Minerais. Be lém, Museu Paraense Emīlio Goeldi, 40p. (Boletim nọ 17, série Geologia).

FUNDAÇÃO INSTITUTO BRASILEIRO DE .GEOGRAFIA E ESTATISTICA, 1968. Divisão do Brasil em Micro-regiões Homogêneas. Rio de Janei ro, IB GE, $563 p$. 
GOES FILHO, F. et alii, 1973. Estudo fitogeogräfico da folha SA 23 São Luiz e parte da folha SA 24 Fortaleza. In: BRASIL De partamento Nacional da Produção Mineral. Projeto RADAM. Levan tamento de Recursos Naturais. Rio de Janeiro, DNPN v.3.

GREENLAND D.J. e P.H. Nye, 1959. Increases in carbon and nitro gen contents of tropical soil under natural fallows. J. Soil. Sci, Londres, $\underline{9}(2): 284-299$.

HUDSON, N., 1971. Soil Conservation. New York, Cornell Univer sity Press, $320 p$.

JENKINSON, D.S. E D.S. POWLSON, 1976. The effects of biocidal treatments on metabolism in soil. V. Method for measuring soil biomass. Soil Biology and Biochemistry. Oxford, $\underline{8}(3)$ : $209-213$.

KIEHL, E. J., 1979. Manual de Edafologia. Relações solo-planta. S. Paulo, Editora Agrọnộmica Ceres; 264 p.

KLINGE, H. e W.A. RODRIGUES, 1968. Litter production in a rea of amazonian terra firme forest. I. Litter-fall, organic carbon and total nitrogen contents of litter. Amazōniana.kiel, I(4): $95-98$.

KLINGE, H.; W.A. RODRIGUES; E. BRUNIG E E.J. FITTKAU, 1975 Biomass and structure in a central amazonian rain forest.In : GOLLEY, F.B. e E. MEDINA, Ed. Tropical ecological systems. Trends in terrestrial and aquatic research. New York,Springer -Verlag, p.115-122 (Ecological Studies, v. 11). 
KUHLMANN, E., 1977. Vegetação. In: FUNDAÇÃO DO INSTITUTO BRASI LEIRO DE GEOGRAFIA E ESTATISTICA. Geografia do Brasit, Região. Norte. Rio de Janeiro, IBGE, p. 59-91.

LESCURE, J.P., 1978. An architectural study of the vegetation's regeneration in French Guiana. Vegetatio, 37(1):53-60.

LESCURE, J.P. e F. PREVOST, 1979. Etude de la forēt guyanaise et de sa regeneration: etat d'avancement des travaux. In : SCHIRLE, A. et alii, Ed. L'ecosysteme forestier guyanais.

Etude et mise en valeur. Cayenne, ORSTOM, p. 35-38. (Bulletin de liaiason du grupe de travaux, no 2).

LESCURE, J.P., 1981. La vegetation et la flore dans la region de la piste de St. Elie. In: SCHIRLE, A. et alii, Ed.L'ecosys teme forestier guyanais. Etude et mise en valeur. Cayenne, ORSTOM, p. 4-24 (Bulletin de liaison du group de travaux, no 3) .

LESCURE, J.P.; H. PUIG;B. RIERA; F. BEEKMAN; A. BENETEAU E D. LECLERC, 1982. La phytomasse épigeé de la forêt dense en Guyane Française. In: SCHIRLE, A. et alii, Ed. L'ecosysteme. forestier guyanais. Etude et mise en valeur. Cayenne, ORSTOM, p.77-118. Bulletin de liaison du group de travaux, no 6).

LIMA, R.R., 1954. Os efeitos das queimadas sobre a vegetação i dos solos arenosos da região da estrada de ferro de Bragança. Belém, Instituto de Pesquisa Agropecuária do Norte, p.(Boletim no 33). 
MANARINO, R.P.; B. VOLKOFF e C.C. CERRI, 1982. Comparação do humus de capoeira e de floresta natural em latossolo amarelo da região amazōnica, Brasil. In: CERRI, C.C. et alli, Ed. Anais do Colóquio Regional sobre Matéria Orgânica do Solo. Pi racicaba, CENA-USP/PROMOCET, p.51-58.

MAURI, G., 1979. Plantulas et regeneration forestiēre en Guyane française: Premiéres constatations sur une coupe à blanc de $25 \mathrm{ha}$. In: SCHIRLE, A. et alij. Ed. L'ecosysteme forestier guyanais. Etude et mise en valeurs. Cayenne ORSTOM, p. 49-53. (Bulletin de liaiason du groupe de travaux, nọ 2).

MEYERS, N., 1982. Depletion of tropical moist forest: A comparati ve review of rates and causes in three main regions. Acta Ama zonica. Manaus, 12(4): 745-758.

MILLER, R.H.; J.J. NICHOLAIDES; P.A. SANCHEZ E D.E. BANDY, 1982. Soil organic matter considerations in agricultural systems of the humid tropics. In: CERRI, C.C. et alii. Ed. Anais do. Colóquio Regional sobre Matéria Orgânica do Solo. Piracicaba, CENA-USP/PROMOCET, p. 105-110.

NIMER, E., 1977. Clima. In: FUNDAÇÃO INSTITUTO BRASILERIO DE GEOGRAFIA E ESTATISTICA. Geografia do Brasil, Região Norte. Rio de Janeiro, IBGE, p. 39-58.

NUNES, et alii, 1973. Geologia da folha SA 23 São Luiz e parte da folha SA 24 , Fortaleza. In: BRASIL. Departamento Nacional da Produção Mineral. Projeto RADAM. Levantamento de Recursos. Naturais. Rio de Janeiro, DMPN, V. 3. 
ORSTOM (s.d.). Méthodes d'analyses ultilisées au laboratorie de physique des sols. Bondy, $30 \mathrm{p}$.

PREVOST, M.F., 1981a. Recrū de trois aus aprēs coupe de type papetier. In: SCHIRLE, A. et alii, Ed. L'ecosysteme fores tier guyanais, Etude et mise en valeur. Cayenne ORSTOM, p. 6881. (Bulletin de liaison du groupe de travaux, no 3).

PREVOST, M.F., 1981b. Evolution d'une jeune forêt secondaire en tre six a sept ans aprés coupe, Pist de St. Elie, Guyane. In: SCHIRLE, A. et alii, Ed. L'ecosysteme forestier guyanais. Etu de et mise en valeur. Cayenne, ORSTOM, p. 82-92 (Bulletin de liaison du groupe de travaux, no 3 ).

PUIG, H., 1979a. Productivité de la forēt primaire guyanaise : etat d'avancement des travaux. In: SCHIRLE, A. et alii. Ed. L'ecosysteme forestier guyanais. Etude et mise en valeur. Cayenne, ORSTOM, p. 49-53. (Bulletin de liaison du groupe de travaux no 2).

PUIG, H., 1979b. Production de litiére en forêt guyanaise : re sultats préliminaires. Bu11. Soc. Hist. Nat.Tolouse, 115(3-4) : $338-346$.

REGO, R.S. et alii, 1973. Estudo detalhado do solo de uma ārea do município de Capitão Poço. Belém, Instituto de Desenvolvimento Econômico-Social do Estado do Parā, 117p. (Série Cadernos Paraenses, no 9). 
ROOSE, E.J., 1979. Dynamique actuelle d'un sol ferrallitique ' trēs désaturē sur sediments argilo-sableux sous culture et sous forêt dense humide subēquatoriale du sud de la cóte d'Ivoire. Adiopodoumé 1964 a 1976. Cah. ORSTOM, sér.Pedol.Paris, $17(4): 259-281$.

SALATI, E., 1983. O clima atual depende da floresta. In:SALATI, E, Coord. Amazônia: desenvolvimento, integração e ecologia. São Paulo, Editora Brasiliense/CNPq, p.15-44.

SALATI, E. e P.B. VOSE (1984). Amazon basin: a system in equili brium. Science. Washington, DC, 225: 129-138.

SANCHEZ, P.A. E S.W. BUOL, 1975. Soil of the tropics and the world food crisis. Science. Washington, D.C., 188: 598-603.

SANCHEZ, P.A., 1976. Properties and management of soils in the tropics. New York, John Wiley \& Sons, 618p.

SANCHEZ, P.A.; D.E. BANDY; J.H. VILLACHICA E J.J. NICHOLAIDES, 1982. Amazon basin soils. management for continuous crop.' production. Science. Washington, D.C., 216: 821-827.

SANTOS, A. dos; M. de N.G. RIBEIRO; J.S. RIBEIRO E S.R.B. BRIN GEL. 1981. Hidroquímica da Amazônia Central. III.Química da àgua de lavagem da floresta no ecossistema campina amazónica (stemflow) : Acta Amazonica, Manaus, 11(2): 335-346.

SANTOS, 0.M. e B.B. CRISI, 1981. Efeito do desmatamento na ati vidade dos microrganismos de solo de terra firme na Amazōnia. Acta Amazonica. Manaus, 11(1): 97-102. 
SARRAILH, J.M., 1982. Premiéres observations sur les pãturages des parcelles de ruissellement et d'érosion. In: SCHIRLE, A. et alii, Ed. L'ecossysteme forestier guyanais. Etude et mise en valuer. Cayenne, ORSTOM, p. 7-18 (Bulletin de liaison du groupe de travaux, nọ 6).

SEUBERT, C.E.; P.A. SANCHEZ e C. VALVERDE, 1977. Effects of land clearing methods on soil properties of an ultisol and crop performance in the amazon jungle or Peru. Trop. Agric. Tri nidad, $\underline{54}(4): 307-322$.

SHUBART, H.O.R., 1983. Ecologia e utilização das florestas. In: SALATI, E., Coord. Amazōnia: desenvolvimento, integração e ecologia. São Paulo, Editora Brasiliense/CNPq, p.101-143.

SHUBART, H.0.R.; W. FRANZEN e F.J. LUIZAO, 1984. Uma floresta sobre solos pobres. In: Ciência Hoje, $\underline{2}(10): 26-32$.

STOOPS, G. E A. JONGERIUS, 1975. Proposal for a micromorphological classification of soil materials. I. A classification of the related distributions of fine and coarse particles. Geoderma. Amsterdam, 13: 189-199.

TAKEUCHI, M., 1960. A estrutura da vegetação na Amazōnia. I. Mata pluvial tropical. Belēm, Museu Paraense Emîlio Goeldi. 37p. (Boletim nọ 6, Nova Série, Botânica).

TOUTAIN, F., 1981. Les humus forestiers, structures et modes de founctionnemente. Revue forestiére française, 23(6): 449-477. 
TURENNE, J.F., 1977. Culture itinerant et jachere forestier en Guyane. Evolution de la matiére organique. Cah. ORSTOM, sér. Pedol. Paris, 15(4): 449-461.

TURENNE, J.F., 1982. Evolution de la matiēre organique en mi lleu forestier guyanais. In: SCHIRLE, A. et alii, Ed. L'e cosysteme forestier guyanais. Etude et mise en valeur. Cay enne, ORSTOM, p. 33-46 (Bulletin de liaison du groupe de tra $\operatorname{vaux} n \div 6)$.

VALVERDE, 0., 1981. Ecologia e desenvolvimento da Amazónia.rev. Bras. Tecnol. Brasîlia, 12(4): 3-16.

VOLKOFF, B. e C.C. CERRI, 1981. Humus em solos da floresta ama zōnica da região do Rio Madeira. Rev. bras. ci. do Solo, Cam pinas, $\underline{5}(1): 15-21$.

VOLKOFF, B.; E. MATSUI e C.C. CERRI, 1982. Discriminação isotō pica do carbono nos humus de latossolo e podzol da região ama zônica do Brasil. In: CERRI, C.C. et alii, Ed. Anais do Coló. quio Regional sobre Matéria Orgãnica do Solo. Piracicaba,CENA. -USP / PROMOCET, P. 147-154.

WOLFRAN, F.; P.R. LEOPOLDO; E. MATSUI e M. de N. RIBEIRO, 1982. Estudo da interceptação da àgua da chuva em cobertura florestal amazónica do tipo terra firme. Acta Amazōnica, Manaus, $327-332$. 
7. APENDICE 
APENDICE 1 - TABELAS 
TABEla $A_{1}$ Percentuais de areia, silte, argila total e grau de floculação do solo no ecossistema natural.

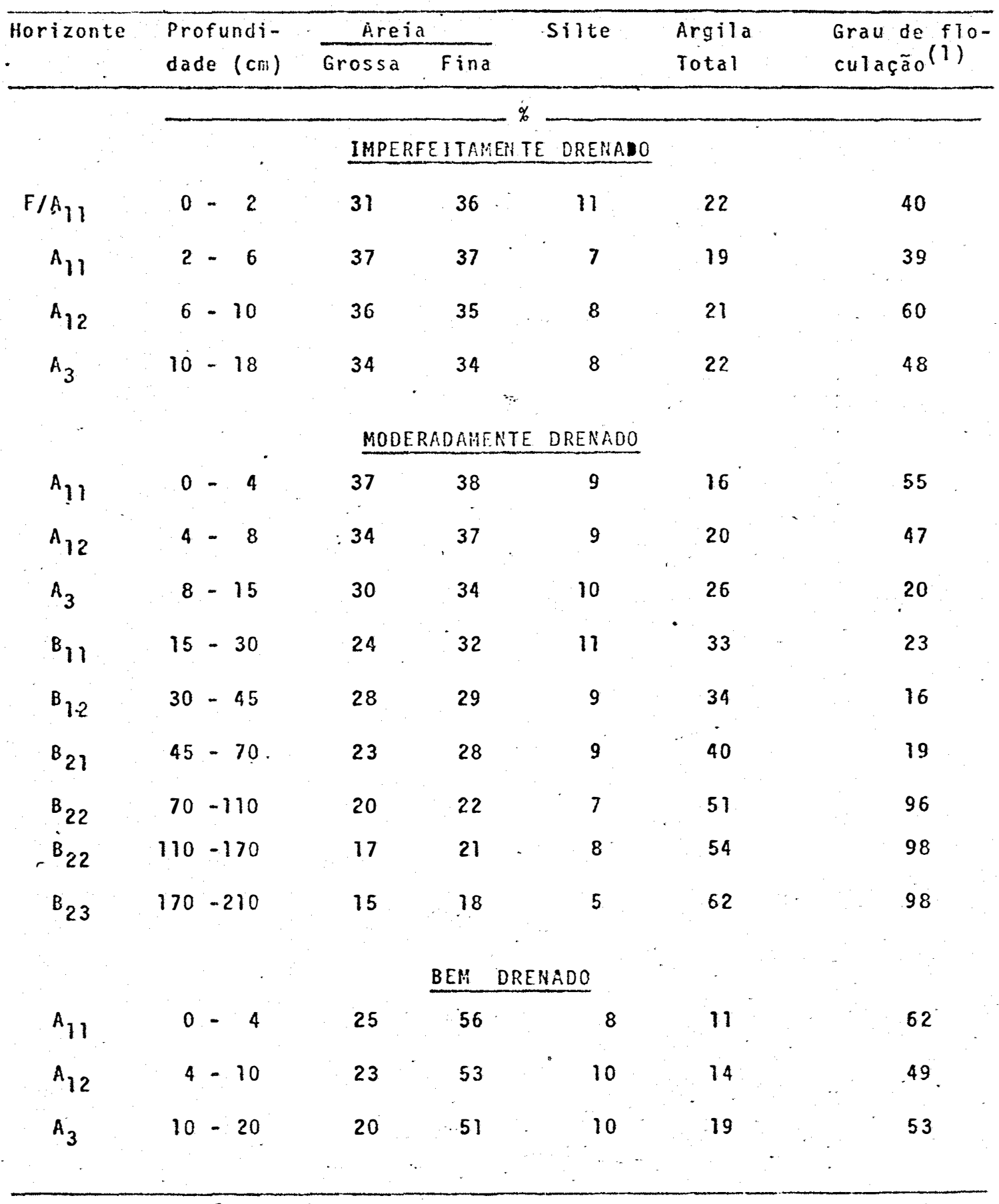

(1)Obtio através da fómula: argila total-argila natural/argila total x 100 
TAEELA $A_{2}$ Percentuais de areia, silte, argila total e grau de floculaçāo do solo no ecossistema alterado.

\begin{tabular}{rlll}
\hline Horizonte & $\begin{array}{l}\text { Profundi- } \\
\text { dade }(\mathrm{cm})\end{array} \frac{\text { Greia }}{\text { Grossa Fina }}$ & $\begin{array}{l}\text { Argila Graude Flo- } \\
\text { Total }\end{array}$ \\
\hline
\end{tabular}

$\ddot{\%}$

$\begin{array}{lrrrrrrr}A_{11} & 0-1 & 37 & 49 & 6 & 8 & 62 \\ A_{11} & 1-4 & 38 & 50 & 5 & 7 & 62 \\ A_{12} & 4-10 & 29 & 53 & 7 & 11 & 54 \\ A_{3} & 10-20 & 24 & 54 & 7 & 15 & 48\end{array}$

CULTIVADO POR 1 ARO

$\begin{array}{lllllll}A_{11} & 0-2 & 38 & 32 & 8 & 22 & 42 \\ A_{11} & 2-6 & 38 & 30 & 8 & 24 & 34 \\ A_{12} & 6-15 & 34 & 31 & 8 & 26 & 33 \\ A_{3} & 15-25 & 28 & 30 & 9 & 33 & 24 \\ B_{11} & 25-35 & 28 & 25 & 10 & 37 & 14\end{array}$

CULTIVADO POR 5 ANOS

$\begin{array}{lrrrrrr}A_{1} & 0-7 & 34 & 45 & 8 & 13 & 23 \\ A_{3} & 7-17 & 33 & 44 & 8 & 17 & 21 \\ B_{11} & 17-32 & 26 & 45 & 7 & 22 & 10 \\ B_{12} & 32-45 & 25 & 43 & 7 & 25 & 18 \\ B_{13} & 45-70 & 24 & 40 & 10 & 26 & 03 \\ B_{21} & 70-95 & 24 & 37 & 9 & 30 & 29\end{array}$

POUSIO DE 3 ANOS APOS 2 ANOS DE CULTIVO

\begin{tabular}{lllllll}
$A_{11}$ & $0-2$ & 42 & 45 & 4 & 9 & 43 \\
$A_{12}$ & $2-7$ & 35 & 45 & 5 & 15 & 28 \\
$A_{3}$ & $7-20$ & 24 & 49 & 5 & 22 & 46 \\
$B_{11}$ & $20-30$ & 28 & 42 & 5 & 25 & 32 \\
$B_{12}$ & $30-40$ & 25 & 42 & 9 & 24 & 18 \\
$B_{13}$ & $40-55$ & 24 & 41 & 8 & 27 & 11 \\
$B_{21}$ & $55-75$ & 21 & 40 & 7 & 30 & 03 \\
\hline
\end{tabular}

(l)obticio atravës da förmula : argila total-argila natural/argila total xloo 
APENDICE 2 - DESCRIÇOEES MORFOLOGICAS DO SOLO 
CLASSIFICAÇÃO: Podzólico vermelho amarelo distrófico-Tb, A moderado, textura média/argilosa, fase floresta tropi cal densa de terra firme, relevo plana.

LOCALIZAÇAOO - Estado do Parā, municīpio de Capitão Poço, Campo Experimental do CPATU, em frente a parcela de cultivo de guaraná em sub bosque do Projeto CPATU 1, a $60 \mathrm{~m}$ do canto esquerdo ante rior, na direção sudoeste.

SITUAÇÃo, DECLIVE E COBERTURA VEgETAL do PERFIL - Trincheira, si tuada em relévo plano, 2 a $3 \%$ declividade, vegetação de floresta natural.

ALTITUDE -

LITOLOGIA - Formação Barreiras

FORMAÇÃO GEOLOGICA - Terciārio

MATERIAL ORIGINARIO - Sedimentos argilo-arenosos

PEDREGOSIDADE - Não pedregosa

ROCHOSIDADE - Não rochosa

RELEVO LOCAL - PI ANO

RELEVO REGIONAL - Suave ondutado

EROSÃO - Não aparente

VEGETAÇÃO PRIMÁRIA - Floresta Tropical densa de terra firme USO ATUAL - Reserva fiorestal

CLIMA - Ami de classificação de Kóppen

$F_{1} / A_{11}-0-2 \mathrm{~cm}$, grumos médios, bruno (10YR 4/3, úmido). mistura dos à abundantes fragmentos de folhas e galhos, e muitas raĩzes finas e mëdias. 
$A_{11}-2-6 \mathrm{~cm}$, bruno (10YR 4/3, ümido) cinza brunado claro

( IOYR $6 / 2$, seco), mosqueado abundante, pequeno e difuso, bruno amarelado escuro (lOYR 4/4); franco arenosa; forte grande a muito grnade granular; ligeiramente duro, muito friável, ligeiramente plástico e ligeiramente pegajoso; transição' clara e plana.

$A_{12}-6-10 \mathrm{~cm}$, bruno (10YR 5/3 úmido), bruno claro acinzentado (1OYR 6/3 seco), mosqueado abundante, pequeno e difuso,bru no (lOYR 4/3); franco arenosa; moderada média a muito gran de granular; ligeiramente duro, muito friāvel, ligeiramente plástico e ligeiramente pegajoso; transição gradual e pla na.

$A_{3}$ - 10-18cm, bruno amarelado (10YR 5/4 úmido) bruno amarelado' claro (IOYR 6/4 seco), mosqueado pouco, pequeno e distinto, bruno forte (7,5 YR 5/8); franco argilo arenosa; fraca mé dia blocos sub angulares; duro, muito friável, ligeiramen te plástico e ligeiramente pegajoso; transição gradual e plana.

$B_{1}$ - 18-32cm, bruno amarelado (10YR 5/4, úmido), bruno amarelado claro (10YR 6/4, seco), mosqueado pouco, pequeno e di tinto, bruno forte (7,5YR 5/8); franco argilo arenosa; maci ça; duro, muito friável, plástico e pegajoso; transição di fusa e plana.

$B_{21}-32-50 \mathrm{~cm}$, bruno amarelado ctaro (10YR 6/4 úmido) bruno 
muito claro acinzentado /10YR $7 / 4$ seco), mosqueado comum, médio e distinto, bruno forte $(7,5 Y R 5 / 8)$, abundante, pe queno e proeminente, amarelo avermelhado (5YR 6/8), pouco, pequeno e proeminente, vermelho (2,5YR 6/8); argilo arenosa; maciça; duro, muito friável, plástico e pegajoso;tran sição difusa e plana.

$B_{22}$ - 50-80cm, bruno amarelado claro (10YR 6/4, úmido), bruno muito claro acinzentado ( $10 Y R$ 7/4, seco), mosqueado comum, grande e distinto, bruno forte (7,5YR 5/8); argilo arenosa; maciça; duro, muito friāvel, plo-tico e pegajoso; transição difusa e plana.

$B_{23}$ - 80-110cm, amarelo brunado (10YR 6/6, ümido) bruno muito claro acinzentado (10YR 8/3 seco) mosqueado abundante, grande e distinto, bruno forte $(7,5 Y R 5 / 8)$; argila; maci ça; muito duro, friāvel, muito plástico e muito pegajoso; transição difusa e plana.

$B_{31}$ - 110-180cm, amarelo brunado (10YR 6/6, úmido), bruno muito claro acinzentado (1OYR $8 / 3$, seco), mosqueado abundante, médio e difuso, amarelo (loYR 7/6), abundante, grande e distinto, amarelo brunado (7,5 YR 6/8); argila; maciça; muito duro, friāvel, muito plástico e muito pegajosostran sição difusa e plana. 
$B_{32}-180-230^{+} \mathrm{cm}$, amarelo brunado (10YR 6/6, ümido), bruno muito claro acinzentado (10YR 8/3, seco), mosqueado comum, médio e difuso, amarelo (10YR 7/6), comum, grande e distinto, ama relo avermelhado (7,5YR 6/8); argila; maciça; muito duro, friāvel, muito plāstico e muito pegajoso. 


\section{Perfil Moderadamente Drenado}

CLASSIFICAÇÃO: Podzōlico vermelho amarelo distrófico - Tb, A moderado, textura média/argilosa fase floresta tropical densa de terra firme, relevo plano.

LOCALIZAÇÃo - Estado do Pará, município de Capitão Poço, Campo Experimental do CPATU, a $100 \mathrm{~m}$ do canto esquerdo anterior da par cela de cultivo de guaranā em sub-bosque do projeto CPATU 1 , na direção noroeste.

SITUAÇAO: Trincheira situada em relevo plano; 1 a $2 \%$ de declividade, vegetação de floresta natural.

\section{ALTITUDE -}

LITOLOGIA - Formação Barreiras

FORMAÇÃO GEOLđGICA - Terciārio

MATERIAL ORIGINARRIO - Sedimentos argilo-arenosos

PEDREGOSIDADE - Não pedregosa

ROCHOSIDADE - Não rochosa

RELEVO LOCAL - Plano

RELEVO REGIONAL - Suave ondulado

EROSAOO - Não aparente

VEGETAÇÁO PRIMARIA - Floresta Tropical densa de terra firme USO ATUAL - Reserva florestal

CLIMA - Ami da classificação Koppen 
$A_{11}-0-4 \mathrm{~cm}$, bruno (TOYR 4/3, úmido) cinza brunado claro (10YR 6/2, seco), mosqueado abundante, pequeno e difuso, bruno amarelado escuro (1OYR 4/4); franco arenosa; forte grande a muito grande granular; ligeiramente duro, muito friável, ligeiramente plástico e ligeiramente pegajoso, transição. clara e plana.

$A_{12}-4-8 \mathrm{~cm}$, bruno (10YR 5/3, úmido) bruno claro acinzentado ( 10 YR $6 / 3$, seco) mosqueado $\because$ abundante, pequeno e difuso,brü no (1OYR 4/3); areia franca; moderada média a muito grande granular; ligeiramente duro, muito friāvel, não plástico' e não pegajoso; transição clara e plana.

$A_{3}-8-15 \mathrm{~cm}$, bruno amarelado (1OYR 5/4 úmido), bruno amarelado claro (lOYR 6/4 seco); franco argilo arenosa; maciça;duro, muito friāvel, ligeiramente plástico e ligeiramente pegajoso; transição gradual e plana.

$B_{11}-15-30 \mathrm{~cm}$, bruno amareliado (10YR 5/6, úmido), bruno amarela do claro (lOYR 6/4, seco); franco argila arenosa; maciça; duro, muito friāvel, plástico e pegajoso; transição difusa e plana.

$B_{12}-30-45 \mathrm{~cm}$, bruno amarelado (10YR 5/6, úmido), bruno muito claro acinzentado (1OYR 7/3, seco); franco argilo arenosa; maciça; duro, muito friāvel, plāstico e pegajoso; transi ção difusa e plana.

$B_{21}-45-60 \mathrm{~cm}$, bruno amarelado, claro (10YR 6/4, úmido) brunó 
muito claro acinzentado ( $10 Y R 7 / 4$, seco ) argilo arenosas; maciça; duro multo friāvel, plástico e pegajoso; transição difusa e plana.

$B_{22}-60-110 \mathrm{~cm}$, amarelo brunado (10YR 6/6, úmido), amarelo(10YR $7 / 6$ seco) mosqueado abundante, médio e proeminente, verme Tha (2,5YR 5/8); argilo arenosa; maciça; duro, friāvel, plāstico e pegajoso; transição difusa e plana.

$B_{23}-110-170 \mathrm{~cm}$, coloração variegada, constituída de amarelo bru nado (lOYR 6/6, ümido) amarelo (lOYR $7 / 6$ ) e vermelho( 2,5 YR 5/8, ümido) vermelho claro, (2,5YR 6/8 seco); argila; maciça; duro, friável; muito plástico e muito pegajoso; transição difusa e plana.

$B_{31}-170-210 \mathrm{~cm}$, vermelho amarelado (5YR 5/6 úmido) amarelo aver melhado (5YR 6/6 seco); argilla; maciça; duro, friāvel, muitóplástico e muito pegajoso. 
CLASSIFICAÇAO: Latossolo amarelo distrófico, A moderado, textura média, fase floresta tropical densa de terra firme; relevo.plano.

LOCALIZAÇÃo - Estado do Parā, município de Capitão Poço, área ex perimental do planalsucar, a $300 \mathrm{~m}$ do barracão de alvenaria, na direção noroeste.

SITUAÇAO - Trincheira situada em relevo plano; 1 a $2 \%$ de declivi dade, vegetação de flöresta natural.

\author{
ALTITUDE - \\ LITOLOGIA - Formação Barreiras \\ FORMAÇÃO GEOLOGICA - Terciārio \\ MATERIAL ORIGINARIO - Sedimentos argi1o-arenosos \\ PEDREGOSIDADE - Não pedregosa \\ ROCHOSIDADE - Não rochosa \\ RELEVO LOCAL - PIANo \\ REIEVO REGIONAL - Suave ondulado \\ EROSAOO - Não aparente \\ VEGETAÇÃO PRIMARIA - Floresta Tropical densa de terra firme \\ USO ATUAL - Reserva florestal \\ CLIMA - Ami de classificação de Koppen.
}


$A_{11}-0-4 \mathrm{~cm}$, bruno (10YR $4 / 3$ ümido) bruno claro acinzentado(10YR $6 / 3$, seco) mosqueado abundante, pequeno e difuso amarelado escuro, (10YR 4/4) abundante pequeno e difuso, preto bruna do (10YR 3/2); areia franca; moderada média a muito grande granular; macia a ligeiramente duro, muito friável, não plástico e não pegajoso; transição clara e plana.

$A_{12}-4-10 \mathrm{~cm}$, bruno (10YR 4/3 úmido), bruno (10YR 5/3) seco, mos queado abundante, médio e difuso bruno (10YR 5/3) abundante pequeno e difuso, acinzentado escuro (10YR 4/2); franco arenosa; fraca média a muito grande granular; macia, muito friāvel, não plástico e não pegajoso; transição gradual e plana.

$A_{3}-10-20 \mathrm{~cm}$, bruno amarelado (10YR 5/4 úmido) bruno amarelado claro (10YR 6/4 seco) mosqueado abundante, médio e difu so, bruno (10YR 4/3); franco arenosa; fraca pequena a mé dia, blocos subangulares, ligeiramente duro, muito fria vel, ligeiramente plástico e ligeiramente pegajoso, tran sição gradual e plana.

$B_{11}-20-50 \mathrm{~cm}$, bruno amarelado (10YR 5/6 limido) amarelo (10 YR 6/6 seco) mosquéädo comum, grande e difuso, bruno (10 YR 5/3); franco argilorarenosa; maciça; duro, muito friāvel, plástico e pegajoso; transição difusa e plana.

$B_{12}-50-75 \mathrm{~cm}$, amarelo brunado (10YR 6/6, ümido), amarelo(10 YR 7J6, seco) mosqueado pouco grande e difuso bruno(10YR 5/3); Franco argilo arenosa; maciça; duro, muito friāvel ; 
plástico e pegajoso; transição difusa e plana.

$B_{21}-75-150 \mathrm{~cm}$, amarelo brunado, (10YR 6/8, ümido) amarelo (10YR $7 / 8$ seco) mosqueado pouco, grande e difuso, bruno amarelado (1OYR 5/4); franco argilo arenosa; maciça; duro,friável, plástico e pegajoso, transição clara e gradual.

$B_{22}-150-180^{+} \mathrm{cm}$, amarelo avermelhado $(7,5 Y R, 6 / 8$ ümido) amarelo avermelhado $(7,5 Y R 7 / 8$, seco)jfranco argilo arenosa: maci ça: duro, muito friāvel; plástico e pegajoso. 
Perfil da Area Recēm-queimada

CLASSIFICAÇAOO: Latossolo amarelo distrófico, A moderado, textura mëdia, fase floresta tropical densa de terra firme, relevo plano.

LOCALIZAÇÃo. - Estado do Parā, município de Capitão Poço, Ärea ex perimental do Planalsucar, Km da estrada PA-242, a $200 \mathrm{~m}$ do barracão de alvenaria, na direção Norte.

SITUAÇÃO; DECLIVE E COBERTURA VEGETAL DO PERFIL - Trincheira si tuada em relêvo plano; 1 a $2 \%$ de declividade; sem cobertura vege tal.

\section{ALTITUDE -}

LITOLOGIA - Formação Barreiras

FORMAÇÃO GEOLŌGICA - Terciārio

MATERIAL ORIGINARIO - Sedimentos argilo-arenosos

PEDREGOSIDADE - Não pedregosa

ROCHOSIDADE - Não rochosa

RELEVO LOCAL - PIANO

RELEVO REGIONAL - Suave ondulado

EROSÃO - Não aparente

DRENAGEM - Bem drenado

VEGETAÇÃO PRIMĀRIA - Floresta Tropical densa de terra firme USO ATUAL - Area recēm queimada

CLIMA - Ami de classificação de Koppen 
$A_{11}$ - 0-4cm, cinza brunado claro (lOYR 6/2, úmido), cinza claro, (10YR 7/2), mosqueado abundante, médio e difuso, bruno acin zentado (10YR 5/2), abundante pqueno difuso, cinza escuro (lOYR 4/1); areia; grãos simples e fraca pequeno e grande' granular; solto a macio, solto a muito friāvel, não plástị co e não pegajoso; transição clara e plana.

$A_{12}-4-10 \mathrm{~cm}$, bruno amarelado claro (10YR 6/4, ümido) bruno muito claro acinzentado(10YR 7/4, seco), mosqueado abundante, medio e difuso, bruno acinzentado (10YR 5/2) e bruno(10YR 5/3); areia franca; grão simples e fraca pequena a muito grande' granular; solto e macio, solto e thit to friável, não plástico e não pegajoso, transição gradual e plana.

$A_{3}$ - $10-20 \mathrm{~cm}$, amarelo brunado (10YR 6/6, úmido), bruno muito cla ro acinzentado (1OYR $7 / 4$, seco), seco, mosqueado abundante, grande e distinto bruno acinzentado (10YR 5/2); franco arenosa; maciça; ligeiramente duro, muito friāvel, ligeiramente plāstico e ligeiramente pegajoso; transição gradual e plana.

$B_{11}-20-32 \mathrm{~cm}$, amarelo brunado (10YR 6/6, úmido), bruno muito cla ro acinzentado (10YR $7 / 4$, seco), mosqueado abundante, grande e difuso, bruno (10YR 5/3), franco arenosa, maciça, duro, muito friāvel, plástico e pegajoso, transição gradual e pla na.

$B_{12}$ - 32-64cm, amarelo brunado (10YR 6/6, úmido), bruno muito cla ro acinzentado (1OYR $7 / 4$, seco); mosqueado pouco, grande e 
difuso, amarelo avermelhado (7,5YR 6/6); franco argilo are noso, maciço; duro, muito friāvel; plāstico e pegajoso,tran sição difusa e plana.

$B_{21}-64-85 \mathrm{~cm}$, amarelo avermelhado (7,5YR, ümido), amarelo averme1hado( $7,5 Y R$ ( $6 / 8$, seco), mosqueado abundante, gende e difuso, amarelo(10YR 7/6); franco argiloso; maciça, duro, friāvel, plàstico e pegajoso, transição difusa e plana.

$B_{22}-85-100^{+} \mathrm{cm}$, amarelo avermelhado $(7,5 Y R, 6 / 6$, ümido), marelo avermelhado $(7,5$ YR $6 / 8$, seco), mosqueado comum amarelo (YR 7/6); franco argilosa;maciça; duro; friável, plástico e pe gajoso. 
Perfil da Area cultivada por l ano.

PERFIL - PCA

DATA - 08/12/82

CLASSIFICAÇÃO : Podzôlico vermelho amarelo eutrōfico - T, A moderado, textura média/argilosa, fase floresta tro pical densa de terra firme, relevo plano.

LOCALIZAÇAO, MUNICIPIO, ESTADO E COORDENADAS - A cerca de $120 \mathrm{~m}$ na direção oeste do canto anterior esquerdo do projeto CPATU 2 , Eampo Experimental de Capitão Poço, lado esquerdo da estrada Irituia-Capitão Poço(PA- ), $\mathrm{Km}$, Capitão Poço(PA),

SITUAÇAO; DECLIVE E COBERTURA VEGETAL DO PERFIL - Trincheira si tuada em relèvo plano; 2 a $3 \%$ de declividade, sem cobertura vegetal.

ALTITUTE -

LITOLOGIA - Formação Barreiras

FORMAÇÃO GEOLŌGICA - Terciārio

MATERIAL ORIGINARIO - Sedimentos argilo-arenosos

PEDREGOSIDADE - Não pedregosa

ROCHOSIDADE - Não rochosa

RELEVO LOCAL - Prano

RELEVO REGIONAL - Suave ondulado

EROSAOO - Laminar ligeira 
DRENAGEM - Moderadamente drenado

VEGETAÇAO - Floresta tropical densa de terra firme USO ATUAL - Cultivo anual

CLIMA - Ami de classificação de Koppen.

$A_{11}-0-6 \mathrm{~cm}$, bruno(10YR 4/3, ümido), bruno claro acinzentado(YRlo 6/3,seco); franco argilo arenosa, franca muito pequena a me dia blocos subangulares; ligeiramente duro, muito friāvel, não plāstico e não pegajoso; transição clara e plana.

$A_{12}-6-15 \mathrm{~cm}$, bruno amarelado (10YR 5/4, úmido), cinza brunado cla ro (10YR 6/2), mosqueado comum, pequeno e distinto, amarelo avermelhado $(7,5 Y R$ 6/6); franco; argilo arenosa moderada me dia a grande blocos subangulares; muito duro, firme ligeira mente plástico e ligeiramente pegajoso transição clara e plana.

$A_{3}-15-25 \mathrm{~cm}$, bruno amarelado claro (10YR 6/4, úmido), bruno cla ro acinzentado (1OYR 6/3, seco), mosqueado abundante, mēdio' distinto, bruno-forte $(7,5 Y R 5 / 8)$; franco argilosa arenosa ; fraca grande blocos subangulares; extremamente duro, firme, plāstico e pegajoso; transição gradual e plana

$B_{11}$ - 25-35, bruno amarelo claro (10YR 6/4, umido), bruno claro acinzentado (10YR 6/3, seco) mosqueado abundante, médio e distinto, bruno forte (7,5YR 5/8), argilo arenosa; fraca' grande blocos subangulares; extremamente duro, firme, plā tico e pegajoso; transição gradual e plana. 
$B_{12}-35-75^{+} \mathrm{cm}$, bruno muito claro acinzentado (10YR $7 \S 3$, úmido), amarelo (10YR 7/6, mosqueado abundante, grande e proeminente, vermelho amarelado (5YR 5/8); franco argilosa; fraca grande blocos subangulares; extremamente duro, muito firme, plástico e pegajoso. 
Pérfil da Area cultivada por 5 anos

CLASSIFICAÇÃO :Latossolo amarelo distrófico, A moderado, textura média, fase floresta tropical densa de terra firme, retevo plano.

LOCALIZAÇAO - No interior da parcela de cultivo intensivo do Pro jeto CPATU-2, a $12 \mathrm{~m}$ da cerca paralela à estrada e $8 \mathrm{~m}$ da cerca mimite com a parcela de pousio 4 anos, Campo Experimental

SITUAÇÃO; DECLIVE E COBERTURA VEGETAL DO PERFIL - Trincheira aber ta em relēvo plano, $1-2 \%$ de declividade, vegetação secundāria de macega, com alguns núcleos de embaubeira (Cecropia sp.)

LITOLOGIA - Formação Barreiras

FORMAÇÃO GEOLŌGICA - Terciārio

MATERIAL ORIGINARIO - Sedimentos argilo-arenosos

PEDREGOSIDADE - Não pedregoso

ROCHOSIDADE - Não rochosa

RELEVO LOCAL - PIANo

RELEVO REGIONAL - Suave ondulado

EROSÃO - Laminar ligeira

DRENAGEM - Moderadamente drenado

VEGETAÇAO PRIMARIA - Floresta tropical de terra firme USO ATUAL - Cultivo intensivo

CLIMA - Ami da classificação de K४ppen 
$A_{1}-0-7 \mathrm{~cm}$, bruno (10YR 5/3, úmido), bruno claro acinzentado ( 10 YR 6/3, seco), mosqueado abundante, grnade e distinto, bruno amarelado claro (10YR 6/4), abundante, grande e difuso, bru no acinzentado (10YR 5/2) com nucleo distinto, cinza escuro (10YR 4/1) comum, pequeno e proeminente, vermelho amarelado (5YR 5/8); areia franca; fraca mēdia a grande blocos subangulares; duro friāvel, não plāstico e não pegajoso; transição clara e plana.

$A_{3}-7.17 \mathrm{~cm}$, bruno amarelado (10YR 5/6, úmido), bruno amarelado' claro (10YR 6/4, seco) mosqueado abundante, grande e distin to, bruno (10YR 4/3) com nucleo bruno acinzentado escuro (10YR 4/2), abundante, mēdio e proeminente, vermelho amare lado (5YR 5/8); franco arenosa; maciça, duro, friāvel, não plāstico e não pegajoso; transição gradual e plana.

$B_{11}-17-32 \mathrm{~cm}$, amarelo brunado (10YR 6/6, ümido), amarelo(10YR $7 / 6$, seco), mosqueado abundante, grande e distinto, bruno(10 YR 5/3), médio e distinto vermelho amarelado (5 YR 5/8); franco argilo arenosa; maciça, duro, friāvel, ligeiramente plástico e ligeiramente pegajoso; transição difusa e plana.

$\mathrm{B}_{12}-32-45 \mathrm{~cm}$, amarelo brunado (10YR 6/6, ümido), amarelo(10YR7/6 seco), mosqueado comum, pequeno e distinto, amarelo averme1 hado (5YR 7/8), pouco, médio e distinto bruno(10YR 5/3) ; franco argilo arenosa; maciça; duro friāvel, plástico e pe gajoso, transição difusa e plana. 
$B_{13}-45-70 \mathrm{~cm}$, amarelo brunado (10YR 6/8, úmido), amarelo avermeIhado $(8,5 Y R 7 / 8, \sec 0)$, mosqueado pouco, pequeno e distinto, - amarelo avermelhado(5YR 7/8); franco argilo arenosa, maciça; dura, muito friāvel, plāstico e pegajoso; transição difusa e plana.

$B_{21}$ - 70-95 cm, amarelo avermelhado $(8,5 Y R$ 6/8, ümido) amarelo aver - melhado $(8,5 Y R 7 / 8, \operatorname{seco})$, franco argilosa arenosa; maciça; duro, muito friável, plāstico e pegajoso; transição difusa e plana.

$B_{22}-95-120^{+} \mathrm{cm}$, amarelo avermelhado (7,5YR 6/8, úmido), amarelo $\underline{a}$ vermelhado $(7,5 Y R 7 / 8$, seco); argila arenosa; muito duro,friá vel. 
Perfil da Area em Pousio de 3 Anos após 2 Anos de cultivo

CLASSIFICAÇAOO : Latossolo amarelo distrófico, A moderado, textura média, fase floresta tropical densa de terra firme, relevo piano.

LOCALIZAÇAOO - No interior da parcela de Pousio 14 anos do Projeto CPATU-2, a $30 \mathrm{~m}$ da cerca 1 imite com a parcela de cacau e $20 \mathrm{~m}$ da cer ca do fundo, Campo Experimentäl.

SITUAÇAOO; DECLIVE E COBERTURA VEGETAL DO PERFIL - Trincheira aber ta em relévo plano; J a $2 \%$ de declividade, vegetação secundāria' de capoeira.

\section{ALTITUDE -}

LITOLOGIA - Formação Barreiras

FORMAÇÃO GEOLÖGICA - Terciārio

MATERIAL ORIGINARIO - Sedimentos argilo-arenosos

PEDREGOSIDADE - Não pedregosa

ROCHOSIDADE - Não rochosa

RELEYO LOCAL - Plano

RELEVO REGIONAL - Suave ondulado

EROSAOO - Laminar ligeira

DRENAGEM - Bem drenado

VEGETAÇAOO PRIMARIA - Floresta tropical densa de terra firme USO ATUAL - POUSio

CLIMA - Ami da classificação de Küppen. 
$A_{11}-0-2 \mathrm{~cm}$, bruno muito claro acinzentado (10YR $\left.7 / 3\right)$, mosqueado abundante, médio e distinto, bruno(1OYR 5/3), bruno acinzen tado (10YR 5/2) e cinza muito escuro (10YR 3/1); área fran ca; grãos simples e fraca pequena a grande granular, solto e muito friável, não plástico e não pegajoso; transição a brupta e plana.

$A_{12}-2-7 \mathrm{~cm}$, bruno (10YR 5/3, ümido), bruno claro acinzentado ( 10 YR 6/3, seco), mosqueado abundante, médio e difuso bruno acin zentado (loYr 5/2) com nūcleo difuso, cinza escuro(10YR4/1) e bruno amarelado (10YR 5/6); franco arenosa; moderada pe quena a grande granular, grande blocos subangulares; macio e ligeiramente duro, macio e muito friāvel, não plástico e não pegajoso; gradual e plana.

$\bar{A}_{3}-7-20 \mathrm{~cm}$, bruno amarelado (10YR 5/6, ūmido), bruno amarelado claro (10YR 6/4, seco), mosqueado abundante, grande e distin to bruno acinzentado (1OYR 5/2), pouco, pequeno e distinto, bruno forte $(7,5 Y R$ 5/6); franco argilo arenosa moderada me dia blocos subangulares; duro, muito friāvel, ligeiramente' plástico e ligeiramente pegajoso, transição gradual e plana.

$B_{11}-20-40 \mathrm{~cm}$, bruno amarelado (10YR 5/6, ümido), bruno amarelado claro (1OYR 6/4, seco); mosqueado comum, grande e distinto' bruno acinzentado (1OYR 5/2); franco argilo arenosa;maciço, duro, muito friāvel, plástico e pegajoso; transição difusa e plana. 
$B_{12}$ - 40-55 cm, bruno amarelado (10YR 5/6, ūmido), bruno amarelado claro (lOYR 6/4,seco); franco argilo arenosa, maciça; lige ramente duro, muito friāvel, plástico e pegajoso; transição gradual e plana.

$\mathrm{B}_{13^{-}} 55-75^{+} \mathrm{cm}$, amarelo brunado (10YR 6/6, ūmido) bruno muito cla ro acinzentado (10YR $7 / 4$, seco), franca argilosa arenosa, ma ciça; ligeiramente duro, muito friāvel, plástico e pegajoso. 
APENDICE 3 - RELAÇAOO DE SIGNIFICADOS dé TERMOS MICROMORFOLOGICOS 


\section{RELAÇAOO DE SIGNIFICADOS DE TERMIS MICROMORFOLOGICOS}

Argilans - material cutānico constituído por argilo-minerais, geralmente misturados com outros constituintes (1).

Canais - Vazios constituidos de poros de forma tubular, maiores que os resultantes do empilhamento de grãos ou indivíduos compostos, tendo normalmente paredes alisadas (1).

Cutans - modificações na textura, estrutura ou trama em superfícies naturais do material de soîo, devidas à concentração de determinados constituintes do solo ou a modificações "in loco" do plasma (1).

Distribuição agrupada - tipo de distribuição de base onde os in dividuos semelhantes se encontram formando agrupamentos (2).

Distribuição de base - tipo de distribuição que diz respeito ao arranjamento de indivíduos semelhantes entre si (2).

Distribuição relativa - tipo de distribuição dos constituintes do fundo matricial que se refere ao arranjamento de indiví duos semelhantes em relação a individuos diferentes - por exemplo: distribuição do esqueleto em relação ao plasma (2).

Esqueleto - conjunto de grãos.

Enaulic - distribuição relativa onde o esqueleto é formado de partículas grosseiras e agregados de material fino que se local $\underline{i}$ zam nos espaços intergranulares (3). 
Glébulas - unidades tridimencionais que aparecem no interior da matriz, de forma aproximadamente elipsodal, ou arredonda da (1).

Grãos - particulas individuais minerais de tamanho superior ao coloidal, originalmente presentes no material de origem (1).

Matriz ou Fundo Matricial - material que se encontra no interior dos peds primārios, ou compondo materiais apédicos. E o conjunto do plasma elou grãos primários e poros associa $\operatorname{dos}(1)$.

Metavazios - vazios cujo alisamento das paredes indica que outros fenomenos se soman a um simples "arranjo estático do plasma e dos grãos do esqueleto" (1).

Monic - distribuição relativa onde somente partículas de uma classe de tamanho está presente (3).

Nódulos - glébulas com trama interna indiferenciada, incluindo a trama de solo ou de rocha (1).

Orientação plásmica - arranjamento do plasma onde os cristais de argila estão organizados em domīnios de orientação relativa, que tem padrões diferenciados de extinção ótica (1).

Ped - agregado individual natural de solo, consistindo em um aglomerado de particulas separado de agregados adjacentes, quer por superficies de fraquezas reconheciveis como poros naturais, quer por ocorrēncia de cutans (1). 
Pedotubos - estruturas associadas consistindo em grãos os grãos em plasma, tendo forma externa tabular, quer em tubos isola dos, quer ramificados (1).

Plasma - todo material de solo de tamanho coloidal (<l m) não aglutinado e/ou retido nos grãos do esqueleto; consiste em material inorgànico (amorfo ou cristalino) elou orgânico que é capaz de ser, ou que tenha sido, movimentado elou concentrado pelos processos de formação do solo (1).

Porfiric - distribuição relativa onde as partículas grosseiras ocorrem em uma massa constituida de material fino (3).

Trama ou "fabric" - constituição física de um material de solo expressa pelo tamanho, forma e arranjo espacial das partícu las sōlidas e dos poros que estão associados às mesmas (1).

Vazios ou poros - partes do solo ocupadis por āgua ou por ar (1).

Vazio Fissural ou Fenda - vazio aplainado, com uma conformação muito complexa das paredes, por ser constituído de nu merosos. e pequenos poros aplainados e curvos. São os poros interpedais dos materiais de solo cujos peds se acomodam uns aos outros. São também os vazios dos materiais apédicos que racham, formando fendas ao secar (1).

(1) baseado em CURI, N., et alii (1985) Coord. Terminologia de micromorfologia do solo. In: Boletim Informativo da So- 
ciedade Brasileira de Ciencia do Solo. Campinas, 10 (2): $33-43$.

(2) baseado em BREWER, R., (1964). Fabric and mineral analysis. of soils. New York, John Wiley \& Sons. 470 p.

(3) baseado em STOOPS, G. e A. JONGERIUS, (1975). Proposal for a micromorphological classification of soil materials. I. A classification of the related distributions of fine and coarse particles. Geoderma, Amsterdam, 13: 189-199. 